MOLECULAR REGULATION OF THE INDUCTION OF CYTOCHROME P-450E IN THE ESTUARINE FISH FUNDULUS HETEROCLITUS

by

Pamela Jean Kloepper-Sams

B.S. Biological Sciences,

University of California at Irvine, Irvine, CA, 1981

SUBMITTED IN PARTIAL FULFILLMENT OF THE REQUIREMENTS FOR THE DEGREE OF

DOCTOR OF PHILOSOPHY

at the

MASSACHUSETTS INSTITUTE OF TECHNOLOGY

and the

WOODS HOLE OCEANOGRAPHIC INSTITUTION

December, 1988

(c) Pamela J. Kloepper-Sams, 1989

\begin{tabular}{c}
\hline MARINE \\
BIOLOGICAL \\
LABORATORY \\
\hline LIB RARY \\
\hline $\begin{array}{c}\text { WOODS HOLE, MASS. } \\
\text { W. H. O. I. }\end{array}$ \\
\hline
\end{tabular}

The author hereby grants to MIT and WHOI permission to reproduce and distribute copies of this thesis document in whole or in part.

Signature of Author

Joint Program in Oceanography,

Massachusetts Institute of Technology/Woods Hole Oceanographic Institution

Certified by

John J. Stegeman, Thesis Supervisor

Accepted by

$v 1$

Donald M. Anderson, Chair,

Joint Committee for Biological Oceanography,

Massachusetts Institute of Technology/Woods Hole Oceanographic Institution

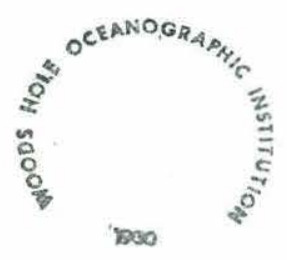




\title{
MOLECULAR REGULATION OF THE INDUCTION OF CYTOCHROME P-450E IN THE ESTUARINE FISH FUNDULUS HETEROCLITUS
}

by

\author{
Pamela Jean Kloepper-Sams
}

\begin{abstract}
submitted in partial fulfillment of the requirements for the degree of
\end{abstract} Doctor of Philosophy

\begin{abstract}
Induction of the aryl hydrocarbon hydroxylase (AHH) P450IA1 occurs in many organisms following exposure to polycyclic aromatic hydrocarbons (PAH). Regulation of induction of P450IA1 (called P-450E) was examined in the estuarine teleost Fundulus heteroclitus. Antibodies were a primary tool in this work; their specificity and cross reactivity with other species were investigated by immunoblot and catalytic inhibition studies. Scup (Stenotomus chrysops) P-450E protein had been previously purified (Klotz et al., 83) and antibodies generated against it (Park et al., 86a). Monoclonal antibody (MAb) 1-12-3 reacted only with $\mathrm{P}-450 \mathrm{E}$ when tested in immunoblot analysis with five scup P-450 fractions. This and six other MAbs recognized purified P-450E, as well as a single comigrating band in microsomes from B-naphthoflavone- (BNF) treated scup. Polyclonal antibodies (PAb) reacted with P-450E but not with other scup P-450 fractions, and reacted strongly with the BNF-induced, comigrating band. PAb also faintly recognized other microsomal proteins, which were not changed in intensity by xenobiotic treatment. MAb 1-12-3 recognized P-450E induced by 3,4,5,3',4',5'hexachlorobiphenyl and Aroclor treatment and the P-450E orthologue in teleost species including rainbow and brook trout, winter flounder, and Fundulus. $\mathrm{P}-450 \mathrm{E}$ was induced in these fish by BNF and other xenobiotics. P-450E protein content in all fish analyzed correlated with ethoxyresorufin O-deethylase (EROD) activity. EROD was strongly inhibited by MAb 1-12-3 in scup and trout. PAb inhibited AHH and EROD more than 90\%, inhibited ethoxycoumarin O-deethylase by about $60 \%$, and did not inhibit aminopyrine $\mathrm{N}$-demethylase, confirming the identity of P-450E as the major inducible EROD and AHH catalyst in these fish. Several MAbs and the PAb recognized purified rat P450IA1 and a BNF-induced, comigrating band in microsomes. MAb 1-12-3 and the PAb also recognized a second band, which comigrates with P450IA2, in microsomes from BNF-treated rats. These results establish the identity of P-450E in scup and other fish and the immunochemical relationship of P-450E with rat P450IA1.

The mode of PAH-type induction was investigated by examining hepatic P-450E content, catalytic activity, and mRNA levels in Fundulus after exposure to a single dose of BNF. In a 20 day experiment, EROD was elevated in BNFtreated animals from Day 4 through Day 20. Increases in immunodetectable P-450E showed the same trend, with low control values and at least a 19-fold
\end{abstract}


increase in the BNF-treated fish. Teleost RNA was used in in vitro translation reactions in the presence of $\left[{ }^{3} \mathrm{H}\right]$-leucine. Precipitation of Fundulus liver RNA translation products with anti-P-450E PAb gave no detectable signal from control fish, while the BNF-treated animals showed incorporation of $\left[{ }^{3} \mathrm{H}\right]$-leucine in a single $56,000 \mathrm{M}_{\mathrm{r}}$ band. In a 48 hour experiment, EROD and P-450E levels were again coordinately increased in response to BNF treatment, and immunoprecipitation of translation products showed increased signal at all times 6 hours or more post-treatment. cDNA pfP $1450-3$ ', which encodes trout P450IA1 (Heilmann et al., 88), yielded unique bands on Southern blots with scup, trout and Fundulus DNA. A Northern blot of RNA from BNF-treated Fundulus showed increases in a single band with time when probed with the trout cDNA. P-450E mRNA increases preceded P-450E protein and EROD increases by about $25 \mathrm{hr}$, supporting the hypothesis that transcriptional activation is involved in induction of $\mathrm{P}-450 \mathrm{E}$ in fish. In another BNF study, Fundulus P-450E mRNA levels declined rapidly, returning to control levels by 5 days, while protein and activity levels remained elevated for at least 13 days. Thus, P-450E expression also appears to be under other forms of regulatory control.

Microsomal protein, P-450E protein, and P-450E heme half-lives ( $\left.\mathrm{t}_{1 / 2}\right)$ were examined in Fundulus during elevated P-450E expression. Decay in incorporated radiolabel $\left(\left[{ }^{3} \mathrm{H}\right]\right.$-leucine and $\left[{ }^{14} \mathrm{C}\right]$-ALA) was followed over time. The immunoprecipitation method used for RNA translation products was modified for precipitation of $\mathrm{P}-450 \mathrm{E}$ protein from microsomes. A preliminary experiment indicated that $F$ undulus microsomes contained no free labeled amino acid at 2 or $23 \mathrm{hr}$ after injection, and that specific radioactivity was higher at 2 than at $23 \mathrm{hr}$. In a longer experiment, $\left[{ }^{14} \mathrm{C}\right]$ counts were not detectable in total microsomes, but peak $\left[{ }^{3} \mathrm{H}\right]$ incorporation into microsomal protein was observed at $1.5 \mathrm{hr}$ after injection, followed by a rapid decrease and stabilization at $30 \mathrm{hr}$. A calculation of the "rapid" and "slow" phases indicated that microsomal proteins had a "fast" $t_{1 / 2}$ of $9.3 \mathrm{hr}$ and a "slow" $\mathrm{t}_{1 / 2}$ of $190 \mathrm{hr}$. Both $\left[{ }^{14} \mathrm{C}\right]$ and $\left[{ }^{3} \mathrm{H}\right]$ were detectable in PAb-precipitated P-450E. Leucine incorporation peaked at $1.5 \mathrm{hr}$, with a second peak at $190 \mathrm{hr}$. Using only the early time points, P-450E protein was calculated to have a $\mathrm{t}_{1 / 2}$ of $32 \mathrm{hr}$. This was consistent with the $43 \mathrm{hr}$ calculated from the time for P-450E to reach half the induced steady state. $\left[{ }^{14} \mathrm{C}\right]$ incorporation peaked at 8 $\mathrm{hr}$, indicating a lag between leucine and ALA incorporation into the holoenzyme. The subsequent decline in $\left[{ }^{14} \mathrm{C}\right]$ was relatively slow, leading to a calculated heme $\mathrm{t}_{1 / 2}$ of $104 \mathrm{hr}$. Further studies of heme and apoprotein turnover will be needed to firmly establish the roles of these players in the regulation of P-450E expression.

This study addressed, on a molecular level, how xenobiotics in the marine environment elicit a biochemical response - induction of P-450E - in marine teleosts.

Thesis Supervisor: John J. Stegeman, Senior Scientist, WHOI 


\section{ACKNOWLEDGEMENTS}

First, I thank John Stegeman for giving me a free hand to explore questions of P-450 regulation, for supplying pertinent suggestions, improvements, and new directions when needed, providing financial support, and always challenging me to strive for more.

I also thank the many members of the lab, who have all contributed to my growth as a scientist and, I hope, as a person. Bruce Woodin, our mainstay, provided Hadley's Harbor cruises, an intro to bluefishing, marshing in March (!), the "chicken" band, and persistantly accurate scribing. Beth Snowberger Gray was always a step ahead and thus showed how to proceed in science (and the JP); we'll both remember Vince's throws to home and Springsteen on the Jersey pike. .. Alan Klotz introduced me to P-450 purification during my first summer in Woods Hole and set a hard-to-follow example. Mark Hahn provided many insights into heme and other questions, as well as a continuous supply of reprints. Adria Elskus was a source of friendship, moral support, and grammatical knowledge. Jay Gooch added a "chemical" dimension and some late night talks, and returning investigators Hanuman Singh and Neal Cornell taught me about science and that nice guys CAN be successful.

My thesis committee was always ready with feedback and encouragement, and traveled some distance, even in non-bluefishing season, to attend meetings. I also thank the Biology faculty at MIT, who challenged me from the outset of my tenure in the JP, and my fellow sufferers in 7.30, with whom I learned to take apart and reassemble scientific arguments. Drs. Harry V. Gelboin and Sang S. Park (National Cancer Institute, NIH) produced crucial monoclonal antibodies and supplied these antibodies as needed. The Education Office provided funding for travel and patiently answered procedural questions. The 
Biology softball team put up with my coaching and co-coaching for several years, the knitting group provided relaxing evenings and a little gossip, and the student rep "round table" was enjoyable and actually worthwhile. Various housemates tolerated us during this period, and old friends, Dave, Amy, my parents, and my in-laws provided unflagging moral support and a breath of life beyond grad school.

And finally, to Henning, who has faced a new language, a new culture, a new career, a new Bekanntenkreis, and multiple moves just to be with me: what can I say? It must be the cheesecake. Thanks for the smiles, the steady encouragement, the tolerance of long hours, and for being there. As before, and now more than ever:

Wie jede Blüte welkt und jede Jugend

Dem Alter weicht, blüht jede Lebensstufe,

Blüht jede Weisheit auch und jede Tugend

$\mathrm{Zu}$ ihrer Zeit und darf nicht ewig dauern.

Es muß das Herz bei jedem Lebensrufe

Bereit zum Abscheid sein und Neubeginne,

Um sich in Tapferkeit und ohne Tauern

In andre, neue Bindungen zu geben.

Und jedem Anfang wohnt ein Zauber inne, Der uns beschützt und der uns hilft, zu leben....

"Stufen" von Hermann Hesse

Das Glasperlenspiel

This research was funded by the Massachusetts Institute of Technology/Woods Hole Oceanographic Institution Joint Program, U.S.P.H.S. grant ES-4220, U.S. EPA grants CR-813155-01-0 and CX-813567-01-1, and NSF grant OCE83-10505. 
Abstract 3

Acknowledgements $\quad 5$

$\begin{array}{ll}\text { List of Tables } & 10\end{array}$

$\begin{array}{ll}\text { List of Figures } & 11\end{array}$

$\begin{array}{ll}\text { Abbreviations } & 13\end{array}$

CHAPTER I: INTRODUCTION 15

Introduction 16

Review of the Mammalian Literature 18

General P-450s

Inducible Mammalian P-450s

Regulation of P450IA1

Regulation of Other P-450s

Molecular Evolution of P-450s

Review of the Teleost Literature 38

$\mathrm{P}-450$ s in Aquatic Animals

Molecular Aspects and Regulation of Teleost P-450s

Environmental Monitoring

General Aims of Research and Specific Questions

CHAPTER 2: SPECIFICITY AND CROSS-REACTIVITY OF MONOCLONAL AND POLYCLONAL ANTIBODIES AGAINST

CYTOCHROME P-450E OF THE MARINE FISH SCUP (reprint) 51

Preamble $\quad 52$

Introduction $\quad 57$

Materials and Methods $\quad 58$

Animals

Treatment

Enzyme preparation and activity assays

Antibody production and characterization

Immunoblot analysis 
Isozyme specificity

$\mathrm{P}-450 \mathrm{E}$ in microsomes

Cross-reactivity among teleosts

Cross-reactivity with mammals

Catalytic inhibition

$\mathrm{P}-450 \mathrm{E}$ in untreated fish

Discussion

64

References

66

Afterword

68

CHAPTER 3: REGULATION OF P-450E IN FUNDULUS

HETEROCLITUS I: P-450E PROTEIN AND EROD ACTIVITY AND INITIAL RNA WORK

Introduction

72

Materials and Methods

Chemicals and General Procedures

Animals

Microsomal Preparation and Protein Studies

RNA Isolation

In vitro Translation of RNA and Immunoprecipitation

Statistics

Results

Induction of P-450E Enzyme Activity

Induction of P-450E Protein Levels

RNA Isolation

RNA in vitro translations and immunoprecipitation

Discussion

98

CHAPTER 4: REGULATION OF P-450E IN FUNDULUS

HETEROCLITUS II: TEMPORAL PATTERNS OF P-450E

PROTEIN AND mRNA INDUCTION

Introduction

Materials and Methods

General Methods

Plasmid Isolation

$\mathrm{pfP}_{1} 450$-3' Isolation and Labeling

Isolation of Genomic Teleost DNA

Southern (Genomic) Blots 
Northern (RNA) Blots

Results

Plasmid and cDNA Isolation and Characterization

Southern Blot Analysis

Induction of P-450E Activity \& Protein Levels - short term study

Induction of P-450E mRNA Levels - short term study

Decline in P-450E mRNA Content

Discussion

CHAPTER 5: PROTEIN AND HEME TURNOVER STUDIES IN

FUNDULUS HETEROCLITUS

Introduction

General Protein Turnover

General Heme Turnover

Protein Turnover in Fish

Heme Turnover in Fish

Materials and Methods

General Methods

Antibody Production \& Immunoprecipitation of Microsomal P-450E

Experiment 1: Animal Treatment \& Preparation of Microsomes Sample Counting and dpm Calculations

Experiment 2: Dual Label Materials and Methods

Statistics

Results

Immunoprecipitation of Microsomal P-450E - Early Attempts

Experiment 1: Basic Parameters \& $\left[{ }^{3} \mathrm{H}\right]$-Leucine Incorporation

Experiment 1: Immunoprecipitation

Experiment 2: Basic Parameters

Experiment 2: Incorporation of $\left[{ }^{3} \mathrm{H}\right]$ and $\left[{ }^{14} \mathrm{C}\right]$

Discussion

CHAPTER 6: SUMMARY AND CONCLUSIONS

I. Regulation of P-450E Induction in Fundulus heteroclitus 186

II. Speculations and Future Directions

I. Induction of P-450E by PCB Congeners 197

II. Scup P-450E mRNA Induction 203

$\begin{array}{ll}\text { BIBLIOGRAPHY } & 207\end{array}$ 


\section{LIST OF TABLES}

Chapter 1:

Table 1-1: Some Rat Hepatic P-450s and their Characteristic Properties

Table 1-2: P450IA Orthologues

Table 1-3: Teleost Hepatic P-450s: Physical Properties and Catalytic Activities

Chapter 2:

Table I: Quantitation of Immunoblot of Cytochrome P-450E and Scup Liver Microsomes with MAb 1-12-3

Table II: Inhibition of BNF-treated Scup Hepatic Microsomal Activity by Polyclonal Anti-P-450E

Table III: Inhibition of EROD Activity in Hepatic Microsomes of Scup and Trout Species by MAb 1-12-3

Table IV: Quantitation of Immunoblot of Individual Feral Scup

Microsomes with MAb 1-12-3

Chapter 3:

Table 3-1: 7 Day Fundulus Experiment: HSI, GSI, and Microsomal Yield

Table 3-2: Fundulus Induction Experiment, Microsomal Characteristics

Table 3-3: Fundulus Induction Experiment (20 day), Microsomal Characteristics

Table 3-4: Teleost RNA Isolation

Table 3-5: Amino-Terminal Sequences of Selected P450IA1s

102

Chapter 4:

Table 4-1: Nick Translation of $\operatorname{pfP}_{1} 450-3$ '

Table 4-2: Monooxygenase parameters in Fundulus following BNF treatment, 48 hours

Chapter 5:

Table 5-1: $\left[{ }^{3} \mathrm{H}\right]$-Leucine Labeled Fundulus - Single Label Experiment 163

Table 5-2: $\left[{ }^{3} \mathrm{H}\right]$-Leucine in Immunoprecipitated Microsomes

Table 5-3: Monooxygenase Parameters in "Dual Label" Fundulus 


\section{LIST OF FIGURES}

Page

Chapter 2:

Fig. 1: Immunoblot of MAb 1-12-3 and PAb 119p with scup P-450s

Fig. 2: Titration of purified $\mathrm{P}-450 \mathrm{E}$ against MAb 1-12-3

Fig. 3: Immunoblot of MAb 1-12-3 with control and BNF-treated scup microsomes

Fig. 4: Immunoblot of various monoclonal antibodies against scup P-450E with purified scup P-450E and BNF-treated scup microsomes

Fig. 5: Immunoblots with control and induced trout and killifish microsomes

Fig. 6: Antibodies to P-450E incubated against rat or scup liver microsomes

Chapter 3:

Fig. 3-1: Temporal response of Fundulus microsomal P-450E protein and EROD activity following BNF treatment, 20 day experiment

Fig. 3-2: Effect of mRNA concentration on [3H]-leucine incorporation

Fig. 3-3: Conditions affecting the efficiency of translation of teleost RNA

Fig. 3-4: Scup and Fundulus RNA in vitro translation products

Chapter 4:

Fig. 4-1: Non-artist's rendition of plasmid pUC19-pfP $1450-3^{\prime}$

Fig. 4-2: Restriction digestion of plasmid pUC19-pfP $1450-3$ '

Fig. 4-3: Southern blot of scup, trout, and Fundulus genomic DNA, hybridized to [ $\left.{ }^{32} \mathrm{P}\right]$-labeled $\mathrm{pfP}_{1} 450-3$ ' cDNA

Fig. 4-4: Relationship between Fundulus P-450E protein levels and EROD activity following BNF treatment, 48 hours

Fig. 4-5: Immunoprecipitated in vitro translation products (P-450E) from Fundulus following BNF treatment, 48 hours

Fig. 4-6: Northern blot of Fundulus RNA, hybridized to [32-P]-labeled pfP $1450-3$ ' trout cDNA

Fig. 4-7: Temporal relationship between Fundulus P-450E mRNA and protein levels following BNF treatment

Fig. 4-8: Decline in P-450E mRNA levels 
LIST OF FIGURES, continued

Chapter 5:

Fig. 5-1: Ratio of PAb 119 to P-450 protein 166

Fig. 5-2: Incorporation and disappearance of $\left[{ }^{3} \mathrm{H}\right]$-leucine in Fundulus liver homogenate and liver microsome fractions 173

Fig. 5-3: $\left[{ }^{3} \mathrm{H}\right]$ (amino acid) incorporation into Fundulus P-450E 174

Fig. 5-4: $\left[{ }^{14} \mathrm{C}\right]$ (heme) incorporation into Fundulus P-450E 176 Appendix:

Fig. A1: PCB congeners 198

Fig. A2: Immunoprecipitated translation products from PCB experiment 201

Fig. A3: Scup MFO parameters and P-450E mRNA levels after treatment with $20 \mathrm{mg} / \mathrm{kg}$ BNF 


\section{ABBREVIATIONS}

20xssc: $3 \mathrm{M} \mathrm{NaCl}, 0.3 \mathrm{M} \mathrm{NaCitrate}, \mathrm{pH} 7.0$ kb: kilobase

$\mathrm{Ah}$ : aromatic hydrocarbon

$\mathrm{kD}$ (a) kilodalton

AHH: aryl hydrocarbon hydroxylase

MAb: monoclonal antibody

AIA: allylisopropyl acetamide

MC: 3-methylcholanthrene

ALA(S): aminolevulinic acid (synthase)

MFO: mixed-function oxidase

ApND: aminopyrine $\mathrm{N}$-demethylase

BCA: bicinchoninic acid

$\mathrm{M}_{\mathrm{r}}$ : apparent molecular weight

BNF: B-naphthoflavone

Mybp:million years before present

BP: benzo[a]pyrene

BPOH: benzo[a]pyrene hydroxylase

BSA: bovine serum albumin

cDNA: complementary ("copy") DNA

$\mathrm{NAD}(\mathrm{P}) \mathrm{H}$ : nicotinamide adenine dinucleotide (phosphate)

nt: nucleotide

OD: optical density

PAb: polyclonal antibody

$\mathrm{cpm} / \mathrm{dpm}$ : counts /disintegrations per min

$\mathrm{CsCl}$ : cesium chloride

PAH: polynuclear (polycyclic)

dCTP: deoxycytidine triphosphate aromatic hydrocarbon

DDC: 3,5-diethoxy carbonyl-1,4-dihydro -2,4,6-trimethyl pyridine

DEPC: diethylpyrocarbonate

$\mathrm{E}_{2}$ : estradiol

ECOD: ethoxycoumarin O-deethylase

$\mathrm{EH}$ : epoxide hydrolase

ER: endoplasmic reticulum

EROD: ethoxyresorufin O-deethylase

EtBr: ethidium bromide

PB: phenobarbital

PCB: polychlorinated biphenyl

PCN: pregnenolone 16-alpha carbonitrile

PHAH: polyhalogenated aromatic hydrocarbon

RIA: radioimmunoassay

SER: smooth ER

$\mathrm{T}$ : testosterone

TCA: trichloroacetic acid

EtOH: ethanol

TCB: tetrachlorobiphenyl

GSH: glutathione

TCDBF: 2,3,7,8-tetrachloro-

GSI: gonadosomatic index dibenzofuran

GTC: guanidine thiocyanate

TCDD: 2,3,7,8-tetrachloro-

HCB: hexachlorobiphenyl dibenzo-p-dioxin

hr: hour

HRP: horseradish peroxidase

TE: Tris/EDTA buffer

HSI: hepatosomatic index

$\mathrm{u}: \quad$ micro

uCi: microCurie

IgG(M): immunoglobulin $\mathrm{G}(\mathrm{M})$ 
14 
CHAPTER I: INTRODUCTION

$\begin{array}{ll}\text { INTRODUCTION } & \text { Page } \\ \text { REVIEW OF THE MAMMALIAN LITERATURE } & 16 \\ \text { General P-450s } & 18 \\ \text { Inducible Mammalian P-450s } & 18 \\ \text { Regulation of P450IA1 } & 20 \\ \text { Regulation of Other P-450s } & 26 \\ \text { Molecular Evolution of P-450s } & 32 \\ \text { REVIEW OF THE TELEOST LITERATURE } & 37 \\ \text { P-450s in Aquatic Animals } & 38 \\ \text { Molecular Aspects and Regulation of Teleost P-450s } & 38 \\ \text { Environmental Monitoring } & 43 \\ \text { GENERAL AIMS OF RESEARCH AND SPECIFIC QUESTIONS } & 47\end{array}$




\section{INTRODUCTION}

Biological oceanography concerns the interactions of marine organisms with the biological, chemical and physical aspects of their environment. A significant class of interactions is that of the organism with organic chemicals in the aquatic milieu. These interactions include chemical challenges by anthropogenic pollutants and other foreign or xenobiotic compounds. When these compounds are hydrophobic, they tend to partition into biological membranes and thus accumulate in tissue. Biotransformation to more polar metabolites is the initial step toward their eventual elimination (or activation, see below). Thus, biotransformation of xenobiotic compounds may affect the survival and reproductive capacity of the individual and population health and distribution.

To understand how an organism responds to chemical exposure, one must not only examine the behavioral (e.g., avoidance), morphological (e.g., weight loss or tumorogenesis) and biochemical (e.g., change in biomolecules) manifestations of its response, but also explore the underlying mechanisms initiating and directing such responses. Accumulation of chemicals within an individual and throughout the food web is frequently related to the physicochemical properties (e.g., $\mathrm{K}_{\mathrm{OW}}$ ) of the chemicals and simple partitioning between a "black box" animal and the water (MacKay, 82; Chiou, 85). It is more realistic and more interesting from a physiological viewpoint to consider the metabolism of such compounds in the organism's attempts to remove them from its body. In animals studied thus far, the enzymes most efficient at xenobiotic transformations are not constitutive to the organism but are induced in the presence of lipophilic compounds similar or identical to those xenobiotics that these enzymes metabolize. The factors regulating such biotransformation - the cellular mechanisms of induction of cytochromes P-450 - will be addressed in this thesis. 
Study of the regulation of the P-450 systems in marine teleosts may serve as a "casebook" of sensitive organismal response to changing conditions in the oceans.

P-450s are related enzymes comprizing a gene superfamily (Nebert et al., 87) that can metabolize xenobiotics such as polynuclear aromatic hydrocarbons (PAH), as well as endogenous compounds such as fatty acids and steroids (e.g., estradiol and testosterone), in mammals, teleosts, and other species (Stegeman, 81). Initially, a xenobiotic is hydroxylated (Phase I), conferring a polar "handle" to the hydrophobic substrate. Hydroxylated intermediates may be enzymatically conjugated (e.g., with glucuronides, Phase II enzymes), to form more highly polar compounds that are then easily eliminated. This is an inactivation or detoxication pathway, a biochemical adaptation in the face of chemical challenge. However, xenobiotics may be activated to deleterious metabolites by certain P-450s and subsequent enzymes. For example, the ubiquitous procarcinogen benzo[a]pyrene (BP) may be biotransformed to a highly reactive dihydrodiol epoxide that reacts rapidly with cellular macromolecules, including vital enzymes and nucleic acids (Weinstein et al., 78). This alkylation of proteins or DNA/RNA may lead to cellular dysfunction or mutation. Therefore, P-450s can be involved in toxification as well as detoxication. Many factors determine which pathway(s) will be followed, including reaction kinetics, the presence of isozymes (specific enzymes of the P-450 gene superfamily) responsible for the initial hydroxylations, and the presence and activity of conjugating enzymes.

Research in the laboratories of Drs. J.J. Stegeman (WHOI) and C. Walsh (MIT) has led to the isolation and characterization of the major aryl hydrocarbon hydroxylating $(\mathrm{AHH})$ enzyme, termed cytochrome $\mathrm{P}-450 \mathrm{E}$, from the marine teleost Stenotomus chrysops (scup). P-450E is the major PAH-inducible form of P-450 and is the major aryl hydrocarbon hydroxylase ( $\mathrm{AHH}$ ) and 
ethoxyresorufin O-deethylase (EROD) catalyst in this species (Klotz et al., 83 and 86). This thesis examines the regulation of induction of xenobiotic-metabolizing P-450s in marine teleosts, focusing specifically on the Fundulus heteroclitus orthologue of scup P-450E. Specific questions addressed in this project include an elucidation of the time course of induction of EROD activity in teleosts, comparison of this activity with levels of the P-450E protein, and examination of the mechanism of P-450E induction at a molecular level. In particular, P-450E mRNA levels are examined to test the hypothesis that transcriptional enhancement underlies the induction of P-450E protein and activity levels. Possible involvement of heme and protein turnover rates in $\mathrm{P}-450 \mathrm{E}$ regulation are also examined. Answers to these questions should provide a clearer understanding of the responses of marine organisms to their environment, as well as interesting parallels to the more thoroughly studied "higher" organisms.

\section{REVIEW OF THE MAMMALIAN LITERATURE}

To obtain an understanding of marine P-450s and how they work - from mechanisms of enzyme activity to molecular regulation - we must first peruse the mammalian literature, because selected mammals (rats, mice, rabbits and humans) have historically been the main focus of study. In this overview, based on the primary literature and Cytochrome P-450: Structure, Mechanism and Biochemistry (Ortiz de Montellano, 86), I will concentrate on mice and rats, since the pioneering work on P-450s and their regulation has been carried out with these animals.

General P-450s

In eukaryotes, the P-450s are a family of membrane-bound hemecontaining proteins exhibiting a characteristic absorption maximum near $450 \mathrm{~nm}$ 
when in the carbon monoxide-bound, reduced form (Omura and Sato, 64). They are the terminal oxidases in reactions in which electron equivalents are passed from reduced nicotinamide adenine dinucleotide (phosphate) $(\mathrm{NAD}(\mathrm{P}) \mathrm{H})$ via the flavoprotein $\mathrm{NAD}(\mathrm{P}) \mathrm{H}$ reductase and the cytochrome to molecular oxygen, activating it and facilitating insertion of one oxygen atom into the substrate (Guengerich and MacDonald, 84; White and Coon, 80). Thus, P-450s are called monooxygenases or mixed function oxidases (MFO). Additional interactions of P-450s with the fatty acid desaturase cytochrome b5 and its reductase occur, but their significance in vivo is not clear (Schenkman et al., 76; Morgan and Coon, 84; DeMarco and McCoy, 85). A simplified scheme of electron flow in the monooxygenase system is shown below.
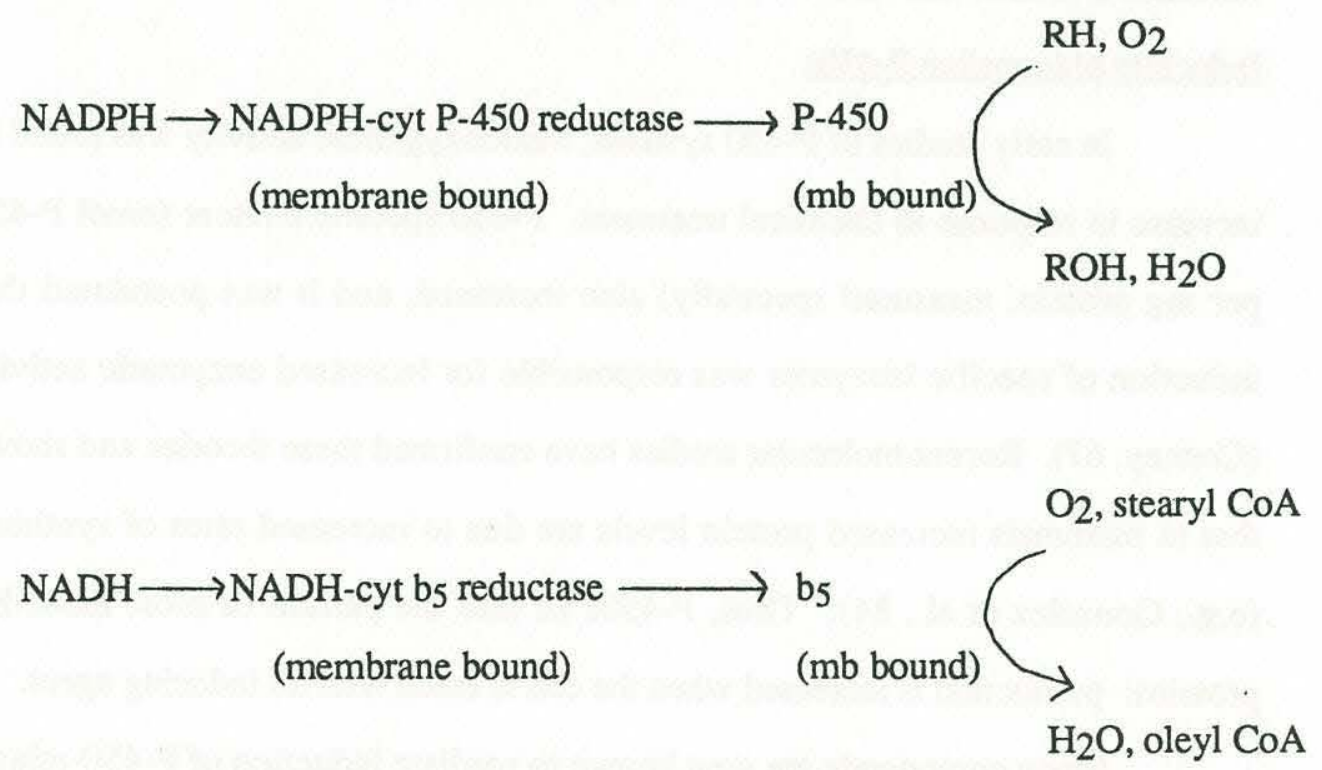

P-450s can catalyze the oxidation, reduction and hydrolysis (including C-, N- and S-oxidation, dehalogenation, epoxidation, desulfurization, dealkylation, and deamination) of a variety of substrates, including steroids, fatty 
acids and lipophilic xenobiotics. Multiple isozymes (Lu and West, 80) with broad and overlapping substrate specificities are responsible for the surprising range of reactions possible. Steroid biosynthesis occurs mainly in the mitochondria and endoplasmic reticulum (ER) of adrenal cortical and gonadal tissue; steroid catabolism occurs mainly in the liver, but also takes place in target organs and the kidney. The oxidative metabolism of xenobiotics, the focus of this discussion, is carried out predominantly by $\mathrm{P}-450$ s located in the smooth endoplasmic reticulum (SER) of hepatic tissue. In general, "constitutive" forms involved in the metabolism of endogenous substrates exhibit greater substrate specificity than those involved in xenobiotic metabolism. For example, the side chain cleavage enzyme (P-450scc or P450XIIA1) is specific for cholesterol only, while PAHinducible P450IA1 can react with a variety of xenobiotics.

Inducible Mammalian P-450s

In early studies of P-450 systems, monooxygenase activity was found to increase in response to chemical treatment. P-450 specific content (nmol P-450 per mg protein, measured spectrally) also increased, and it was postulated that induction of specific isozymes was responsible for increased enzymatic activity (Conney, 67). Recent molecular studies have confirmed these theories and shown that in mammals increased protein levels are due to increased rates of synthesis (e.g., Gonzalez et al., 84). Thus, P-450s fit into the pattern of most inducible proteins: production is increased when the cell is faced with an inducing agent.

Many compounds are now known to mediate induction of P-450-related activity in mammals (Conney, 67; Nebert et al., 81). The major ones include barbituates and other related drugs (e.g., phenobarbital (PB)), PAHs (e.g., 3methylcholanthrene (MC)), and pregnenolone 16-alpha carbonitrile (PCN). This discussion will focus on the PAH-type inducers, the most widely studied type in 
aquatic systems, while mentioning key findings pertaining to the other classes of inducers.

In early studies (Kato et al., 66; review by Conney, 67) enzyme activities, total spectral P-450 and metabolite quantities were measured in subcellular fractions equivalent to the ER (microsomes) after animals were exposed to chemicals. Protein synthesis was found to be necessary for the induction of enzyme activity: inducers did not alter the enzyme's substrate affinity ( $\mathrm{V}_{\max }$ was altered, but $\mathrm{K}_{\mathrm{m}}$ was not); protein synthesis inhibitors actinomycin D and puromycin blocked induction; amino acid incorporation was stimulated; and RNA levels appeared to increase. The focus was on PB- and MC-type compounds, and the existence of multiple isozymes was suggested by differences in substrate preferences, metabolite profiles, and spectral changes seen with the two inducer types. PB treatment resulted in general stimulation, with gross morphological changes (e.g., SER proliferation), increases in microsomal protein yield and stimulation of several different MFO activities. MC provided more limited stimulation, with fewer MFO activities induced and only minor if any morphological changes. More recently, the differential regulation of P-450 activities has been shown to have a molecular basis: separate, discrete mRNAs encode for MC-inducible, $\mathrm{PB}$-inducible, and constitutive $\mathrm{P}-450$ proteins (e.g., Fagan et al., 83).

Many isozymes and their corresponding cDNAs have now been identified. Constitutive P-450s - those generally present in untreated animals, as opposed to those only present after chemical exposure - have been receiving increasing attention due to the development of more powerful techniques for identifying and isolating them. Recent reviews (Schenkman et al., 87; Waxman, 88) include such constitutive isozymes. Table 1-1 lists some of the major 
constitutive and inducible isozymes characterized in rat hepatic microsomes and outlines where applicable their major known inducers and catalytic activities. After years of confusion, a committee of experts (Nebert et al., 87) suggested a unified P-450 nomenclature based on nucleotide sequences. These designations are slowly being implemented in the P-450 field, and I have included some of the more familiar common names in Table 1-1.

Although rat liver microsomes have been the major source of starting material for $\mathrm{P}-450$ purification, some other mammalian species have also been intensively studied. Counterparts to the major rat PAH-inducible forms have been identified and purified in mice and rabbits. Homologous proteins (or genes) are defined as those descended with divergence from a common ancestral gene. Fitch (71) has suggested that homologous proteins should be subdivided into two categories as follows. The first category contains homologous proteins that result from gene duplication, such that both copies descended "side by side" during the history of the organism. These proteins are paralogous proteins (e.g., alpha and beta subunits of hemoglobin). Rat P-450c and P-450d have been proposed to be such products of gene duplication (Adesnik and Atchison, 86). The second category of homologous proteins results from speciation, such that the history of the gene reflects the history of the species. These proteins are labeled orthologous proteins (e.g., alpha hemoglobin in mouse and man). Mouse $P_{1} 450$ and rat P-450c (and scup P-450E!) would thus be considered orthologous proteins; this terminology is utilized throughout this thesis. Table 1-2 lists the P450IA orthologues in three mammalian species, and will serve as a reference in the ensuing discussions. 
TABLE 1-1: Some Rat Hepatic P-450s and their Characteristic Properties

\begin{tabular}{|c|c|c|c|}
\hline Designation $^{a}$ & $\begin{array}{l}\lambda \max , \\
\mathrm{nm}\end{array}$ & $\begin{array}{r}M_{r} \\
\times 1000 \\
\end{array}$ & Inducers/ Major Catalytic Activities ${ }^{b}$ \\
\hline $\begin{array}{c}\text { P-450a (IIA1) } \\
\text { (UT-F, 3) }\end{array}$ & 452 & 48 & $\mathrm{~PB}, \mathrm{MC}$ (minor)// T 7-alpha OH \\
\hline $\begin{array}{l}\text { P-450b (IIB1) } \\
\quad(\mathrm{PB}-\mathrm{B}, \mathrm{PB}-4)\end{array}$ & 450 & 52 & $\mathrm{~PB}($ minor) $/ / \mathrm{T} 16 \mathrm{~B}-\mathrm{OH}$ \\
\hline $\begin{array}{c}\text { P-450c (IA1) } \\
\text { (BNF-B) }\end{array}$ & 447 & 56 & MC, BNF (major), PCB// AHH, EROD \\
\hline $\begin{array}{l}\text { P-450d (IA2) } \\
\text { (ISF-G) }\end{array}$ & 447 & 52 & isosafrole (major), $\mathrm{MC} / / \mathrm{E}_{2} 2-\mathrm{OH}$ \\
\hline $\begin{array}{l}\text { P-450e (IIB2) } \\
\text { (PB-D, PB-5) }\end{array}$ & 450.5 & 52.5 & $\mathrm{~PB}$ (minor)// low activity ( P-450b) \\
\hline P-450f (IIC7) & 447.5 & 51 & untreated// T 16-alpha OH \\
\hline $\begin{array}{l}\text { P-450g (--) } \\
\text { (RLM 3) }\end{array}$ & 447.5 & 50 & male-specific, strain dep.// T 6ß-OH \\
\hline $\begin{array}{l}\text { P-450h (IIC11) } \\
\text { (UT-A, 2c, RLM } 5\end{array}$ & 5) & 51 & male-spec.// T 2-,16-alpha $\mathrm{OH}, \mathrm{E}_{2} 2-\mathrm{OH}$ \\
\hline $\begin{array}{l}\text { P-450i (--) } \\
\text { (UT-I, 2d, RLM 4) }\end{array}$ & 449 & 50.5 & female-specific// steroid disulfate $15 \mathrm{~B}-\mathrm{OH}$ \\
\hline $\begin{array}{l}\text { P-450j (IIE1) } \\
\text { (RLM 6) }\end{array}$ & $451 / 2$ & 51.5 & $\mathrm{EtOH}$, isoniazid// nitrosamine deM \\
\hline
\end{tabular}




$\begin{array}{lrrl}\text { P-450 k (IIC6) } & 450 & 47.5 & \mathrm{~PB} \text {, (hormone indep.)// warfarin 7-OH } \\ \begin{array}{l}\text { (PB-C, PB-1, RLM5a) } \\ \text { P-450p (IIIA1) }\end{array} & & \\ & 450 & 51 & \mathrm{PCN}, \mathrm{PB} / / \mathrm{T} \text { 6B-OH, E2 2-OH } \\ \text { (PB-2a, PCN-E) } & & & \end{array}$

aAlphabethical listing is according to the convention of Levin and co-workers (Ryan et al., 79, 82, 84, and 85), followed by the gene designation, if known (Nebert et al., 87). Other common names are given in the next line.

bKnown inducing chemicals or sex differences are listed here, followed by the major known enzymatic activities of the purified P-450 in reconstituted systems. Absolute values range considerably from laboratory to laboratory so no values are given. Abbreviations not defined in the text are given in the List of Abbreviations.

Data summarized from the following reports, and references therein: Stegeman and Kloepper-Sams, 87; Waxman, 88; Schenkman et al., 87. 
TABLE 1-2: P-450IA a Orthologues

P-450IA1 P-450IA2

Species

rat

P-450c

P-450d

mouse

$\mathrm{P}_{1} 450$

$\mathrm{P}_{3} 450$

rabbit

P-450 6

P-450 4

a See Nebert et al. (87) for details of P-450 isozyme nomenclature. 


\section{Regulation of P450IA1}

The best characterized mechanism of P-450 induction has been elucidated in the P450IA gene subfamily. Initially, it was found that two mouse strains showed differential responses to application of 7,12-dimethylbenzanthracene to the skin. Genetic crosses of "nonresponsive" D2 animals and "responsive" B6 animals indicated an autosomal dominant response; the locus was called In (phenotype inflammation, Taylor, 71). Induction of $\mathrm{AHH}$ activity following MC treatment paralleled the In phenotype ( B6 mice were induced, D2 mice were not); this was termed the $A h$ or aryl hydrocarbon responsive locus (Nebert and Jensen, 79). TCDD (2,3,7,8-tetrachlorodibenzo-p-dioxin) was found to be 30,000 fold more potent as an inducer of $\mathrm{AHH}$ activity than $\mathrm{MC}$ in $\mathrm{B} 6$ mice, and elicited a weak response in D2 mice (Poland and Glover, 74). Because it could be synthesized with high $\left[{ }^{3} \mathrm{H}\right]$ specific activity, TCDD became very useful as both an inducer and a binding tracer in later studies.

Poland and co-workers postulated the presence of a TCDD-binding protein, which could serve as a receptor, based on correlations of exposure to TCDD-analogs with the AHH response (Poland and Glover, 73) and the "toxic potential" of different mouse strains. This "TCDD" or "Ah" receptor was found in murine hepatic cytosol (Poland et al., 76). It binds specifically and reversibly to many polyaromatics, but not to phenobarbital or steroids such as PCN, dexamethasone or 17-OH-corticosterone. No physiological (endogenous) ligands have been found for the $A h$ receptor, leaving open questions on the evolution of response to environmental conditions. Specific binding is not the only characteristic of a classical cytosolic receptor: it must also be transported to the nucleus. Nuclear translocation of the receptor-TCDD complex (Greenlee and Poland, 79) was demonstrated to be temperature and time dependent (Okey et al., 
80). Appearance of the complex in the nucleus corresponds well with $\mathrm{AHH}$ induction in responsive cell cultures (Hepa-1 and H-4-II-E). Nuclear localization of the receptor alone is not sufficient for induction. HTC cells have receptor/cell numbers between those of Hepa-1 and H-4-II-E and exhibit nuclear translocation, but no induction is detectable. Mirroring the controversy over the subcellular localization of the estradiol receptor, there have been conflicting reports on the distribution of "free" (unbound) Ah receptors (references 46 and 47 in Arnold et al., 88). However, there is a consensus that the bound form has an increased affinity for DNA and can be found in the nuclear fraction.

There have been numerous technical difficulties in purifying the $A h$ receptor, but many of its physical properties have been established. It is a cytosolic protein with (under certain conditions) a $\mathrm{M}_{\mathrm{r}}$ of around $100 \mathrm{kD}$, it sediments at 4 to $5 \mathrm{~S}$ in high ionic strength sucrose density gradients, and at $9 \mathrm{~S}$ in lower salt sucrose density gradients, has a Stokes radius of $60 \AA$, adsorbs to hydroxylapatite, interacts with polyanions such as DNA-cellulose and heparinSepharose (Gasiewicz and Neal, 82), and has a high affinity for planar polyaromatic hydrocarbons. It has no affinity for steroid hormones. Its hydrophobic character (Poellinger and Gullberg, 85) may be a dominant factor in determining its ligand binding properties (Bandiera et al., 83). By using molybdate as a stabilizing agent (Denison et al., 86; Manchester et al., 87), a "low affinity" $A h$ receptor has now been found in D2 animals originally thought to lack the receptor (Okey et al., 88).

Like several steroid hormone receptors, the $A h$ receptor appears to form an "inactive" complex (Perdew, 88; Denis et al., 88) with two molecules of hsp 90, a highly conserved heat shock protein (Lindquist, 86). The hsp 90 may serve to cap the ligand binding site in the absence of the ligand, retaining the receptor in the low 
DNA-affinity state (Baulieu, 87). Denison et al. (88) have suggested that, given the high affinity of the TCDD/receptor complex for the third dioxin responsive element upstream of the coding region of the $P_{1} 450$ structural gene, DNA affinity techniques might be successfully exploited for (the imminent) purification of the native $A h$ receptor. With the use of a specifically designed photoaffinity label, Perdew and Poland recently isolated the $A h$ receptor from B6 mice (88). A 20,000 fold purification was achieved, but unfortunately denaturing conditions were necessary in the latter stages of purification.

The concentration of "cytosolic" Ah receptor may not be the dominant factor in determining maximal activity. Treatment with PB can double the concentration of unbound cytosolic $A h$ receptors in responsive mice and rats without increasing the affinity for TCDD or doubling the induction of AHH activity (Okey and Vella, 84). In a comparative study of mammalian species, Denison and Wilkinson (85) were able to identify a TCDD-binding moiety in all animals tested, but saw no relationship between concentration of the receptor and AHH inducibility. Thus, this system may be similar to steroid hormone receptor systems where only a fraction of the total receptor population must be bound to give a maximal response. In a number of mammalian species, Gasiewicz and Rucci (84) found $A h$ receptors with similar biochemical properties which translocate to the nucleus subsequent to TCDD treatment. The receptors have the same order of binding preference to a number of PAHs and dibenzo-p-dioxin congeners. The animals vary in their sensitivity to TCDD, however, indicating that other factors also contribute to these responses.

Attempts to generate monoclonal antibodies (MAb) against the $A h$ receptor have led to the production of antibodies against the $90 \mathrm{kD}$ heat shock protein (Perdew, 88). hsp 90 was apparently a major contaminant or a dominant antigen 
in the partially purified $A h$ receptor fraction. The MAbs generated by Perdew can co-precipitate the $A h$ receptor and the heat shock protein, and may be useful in novel purification schemes. The future availability of monoclonal antibodies specific to the $A h$ receptor should more greatly facilitate studies of this protein and its role in the regulatory pathway of P450IA1.

Another protein, called the carcinogen- or PAH-binding protein or " $4 \mathrm{~S}$ " protein, binds PAHs such as benzo[a]pyrene - but not TCDD - in mouse liver cytosols and has a higher concentration in these tissues than does the $A h$ receptor. It has characteristics consistent with a receptor moiety, including high affinity and saturable binding (Collins and Marletta, 84). Various PAHs bind to the protein, which sediments at $4 S$ in sucrose density gradients, while TCDD and steroids like cortisol, estradiol, and PCN do not. The protein has been purified from mouse and rat cytosols, and has a $\mathrm{M}_{\mathrm{r}}$ of about $40 \mathrm{kD}$ in rats (Arnold et al., 87) and $29 \mathrm{kD}$ in mice (Collins and Marletta, 86). A similar binding moiety has been located in the cytosolic fractions of various vertebrates, including scup and chick (Barton and Marletta, 88; see also Chapter 4 Discussion). Houser et al. (87) found that the $4 \mathrm{~S}$ protein specifically binds one or more upstream regions of the rat P-450c gene, and observed chloramphenicol acetyl transferase (CAT) activity in cells transfected with these regions and treated with MC. This research group also recently described the distribution of the $4 \mathrm{~S}$ protein before and after MC treatment; immunohistochemical analysis suggested that the protein is predominantly found in the cytoplasm of untreated rats and translocates to the nucleus after treatment (Arnold et al., 88). However, there is as yet no consensus as to the physiological function of this protein or its role, if any, in the expression of P450IA1.

The regulatory domains 5 ' of the coding region of mouse $P_{1} 450$ have been examined in detail. The use of variant cell lines and molecular biological 
techniques have provided insights into the interactions between ligands, receptors and gene transcription. Whitlock and co-workers have identified at least three cisacting dioxin-responsive elements (DRE) in the 5' region of the mouse P450IA1 gene (e.g., Jones et al., 85; Denison et al., 88). All three can increase transcription of a heterologous (CAT assay) promoter-run system in an orientation- and distance- independent fashion (e.g, Jones et al., 86; Durrin and Whitlock, 87), and are thus considered enhancer sequences (Lewin, 87). The transcriptional control of the gene also includes a promoter and a putative repressor binding site (Whitlock, 86 and 87; Nebert and Gonzalez, 87). Watson and Hankinson (88) recently transfected genomic DNA from dominant AHH-deficient mutant cells into "wild type" Hepa-1 cells and obtained AHH-negative transfectants. They hope to use this method to lead to the cloning, identification and characterization of a trans-acting negative regulator of $\mathrm{P}_{1} 450$ induction.

Following activation of transcription rates, $\mathrm{P}_{1} 450$ mRNAs begin to accumulate in the cytosol. The time course and magnitude of induction of these specific mRNAs can be determined with molecular techniques. By hybridizing poly(A)-RNA with a mouse $\mathrm{P}_{1} 450$ cDNA clone, Tukey et al. (82) quantitated $\mathrm{P}_{1} 450$ mRNA following TCDD treatment. They found a strong correlation between accumulation of the mRNA and amounts of receptor-ligand complex appearing in the nucleus of D2, B6 and D2/B6 heterozygotic mice. mRNA accumulation may have been due to its stabilization, however, rather than to increases in transcriptional activity. Therefore, rates of transcription were measured directly in isolated mouse nuclei by nuclear run-off analysis. A 20-fold increase in $P_{1} 450$ mRNA synthesis rates was observed in TCDD-treated cultured cells within 30 minutes; this level was maintained for at least 18 hours (Israel and Whitlock, 84). In another study, transcription rates were examined in MC-treated 
mice. D2 mice showed no activation by MC. Transcription rates increased within 3 hours after MC treatment in B6 mice, reaching maximal rates at 12 hours (Gonzalez et al., 84). A 3 to 6 hour lag was observed between transcriptional enhancement and increases in mRNA levels.

Comparison of $\mathrm{P}_{1} 450$ gene expression with that of the paralogous mouse protein, $\mathrm{P}_{3} 450$, has provided further insights into $\mathrm{P}-450$ regulatory mechanisms. $\mathrm{P}_{3} 450$ (P-450d or P450IA2) mRNA induction exhibited a longer lag time than did $P_{1} 450$, although transcription rate increases were temporally similar. Thus, transcription of these two inducible genes may be coordinately controlled, while post-transcriptional processing may differ. Fagan et al. (86) found that in the first 48 hours after treatment of rats with MC, P-450c mRNA levels increased more rapidly than did levels of P-450d mRNA. Both mRNAs achieved peak levels at 24 hours and P-450c mRNA then declined less rapidly than did P-450d. These researchers did not distinguish between transcription and other forms of mRNA regulation.

Although initial studies seemed to indicate that transcriptional enhancement could totally account for the observed increases in mRNA levels, recent reports reveal a more complicated story. When induction studies are conducted in mouse or rat hepatocyte cultures, the relationship between P-450 transcriptional enhancement and prevalence of P-450 mRNA species is not clear-cut. The role of post-transcriptional control, originally thought unimportant, has gained greater prominance. Pasco et al. (88) found that rat P-450d mRNA can accumulate in primary hepatocyte cultures following TCDD treatment, with no changes evident in P-450d transcription rates. A similar study of rat hepatocyte cultures presented evidence for post-transcriptional control in MC-induction of both P-450c and P-450d, although transcriptional control could account for P-450c mRNA 
increases in vivo (Silver and Krauter, 88). Kimura and coworkers found inconsistencies between mouse $P_{1} 450$ and $P_{3} 450$ transcriptional rates and mRNA levels in a number of extrahepatic tissues (Kimura et al., 86). In most of these studies, transcription rates are determined by measuring "nuclear runoff" rates in isolated nuclei. Little is known about the stabilities of the P-450 mRNA species prior to exposure to inducers, so comparisons between different P-450s (e.g., P-450c and P-450d) and different tissues (liver and extrahepatic tissues) generally indicate trends only (e.g., Kimura et al., 86 conclude that TCDD "stabilizes" P-450d mRNA, because the accumulation of the mRNA is greater for P-450d than for P-450c, despite similar fold transcription increases). Further comparative studies, both in vivo and in vitro, may clarify this picture.

In summary, regulation of the expression of P450IA1 involves a soluble receptor that forms a complex with specific ligands and interacts with some portion(s) of the sequence 5 ' to the $\mathrm{P}_{1} 450$ coding region. This interaction leads to transcriptional enhancement of the gene, resulting in accumulation of the gene product and increases in the corrresponding enzyme activities. Other trans- and cis- acting factors are likely to be involved, and the schematic will probably become more complex as new details are learned.

\section{Regulation of Other P-450s}

Other forms of regulation have been investigated in P-450 systems. In one of the few studies on post-translational modifications of P-450 systems, Pyerin et al. (87) found that alkaline phosphatase can decrease the activity of cytochrome $\mathrm{P}-450$ reductase, leading to reductions in measured MFO activities in rat and rabbit microsomes, and that certain isolated isozymes (including rabbit form 2 and rat PB $3 \mathrm{~b}[\mathrm{P}-450 \mathrm{e}]$ and $\mathrm{PB} 3 \mathrm{a}[\mathrm{P}-450 \mathrm{~b}])$ could be phosphorylated in vitro by the catalytic subunit of cAMP-dependent protein kinase. Rabbit form 2, the most closely 
examined, was specifically phosphorylated at serine 128 , resulting in deactivation of the P-450 and conversion to P-420. A calcium-dependent kinase showed a different pattern of isozyme specificity, but its mechanism of action was not investigated. MFO inhibitors decreased tumorigenicity, but only when administered a short while after carcinogenic hydrocarbons were administered (citation in Pyerin et al., 87). Thus, these authors speculate that if similar rapid P-450 inactivations occur in vivo, they could be important in the early stages of tumorigenicity. Such (or similar) methods of rapid, short-term regulation could be essential in regulating normal P-450 functions as well.

Several steroidogenic P-450s are regulated developmentally (Waxman, 88) and/or by peptide hormones, such as adrenocorticotropin (ACTH) via the second messenger cAMP (John et al., 85). Some P-450s involved in endogenous metabolism are integral proteins of the adrenal cortical inner mitochondrial membrane. P-450 ssc and P-450 11ß precursors are synthesized in the cytosol and their transport into the mitochondria is dependent on a membrane potential. Despite preliminary evidence to the contrary, their maturation appears to follow the same steps as the processing of other mitochondrial precursor proteins (Matocha and Waterman, 1985).

It has been shown that transcriptional activation underlies the induction of PB-specific P-450 activities (e.g., Fagan et al., 83). Despite intensive efforts, no receptor analogous to the $A h$ receptor has been found for the genes of the P450IIB subfamily. The synthesis and/or incorporation of heme may play a crucial role in regulating P-450b catalytic activities. Heme synthesis inhibitors, such as cobalt chloride and 3-amino-1,2,4-triazole, inhibit P-450b protein synthesis at the level of P-450b transcription. The normal PB-stimulated increase in transcription rates is inhibited by these chemicals and P-450b mRNA does not accumulate 
(Ravishankar and Padmanaban, 85a and 85b; Dwarki et al., 87). Although most studies have focused on the effects of heme and heme pathway disruptors on $\mathrm{P}-450 \mathrm{~b}$, there is some evidence that they also affect P-450c. A recent article examined the effects of such chemicals on the regulation of P-450 (c+d) (Bhat and Padmanaban, 88), and the authors concluded that heme can act as a positive regulator of gene transcription. As observed with $\mathrm{P}-450 \mathrm{~b}$, addition of hemin overcomes the block on mRNA induction.

Heme may be generally involved in the regulation of P-450 expression at several levels. P-450s are the dominant heme-containing proteins of the ER, containing up to $70 \%$ of the total liver heme in induced animals (Muller-Eberhard and Vincent, 85). In mammals, heme appears to act as a feedback inhibitor. While not directly inhibiting the activity of delta-aminolevulinic acid synthase (ALAS), heme inhibits the transcription, translation, and translocation of ALAS (the rate-limiting enzyme in the hepatic heme biosynthetic pathway). As is expected for enzymes at the regulatory points in biosynthetic pathways, ALAS protein has a short half-life (e.g., 35 minutes in the rat and 120 minutes in the chick embryo, compared to several days for the "average" mitochondrial protein; references in May et al., 86). ALAS mRNA also has a rapid turnover, with a halflife of about 5 hours. Heme also induces heme oxygenase, the rate limiting enzyme in the degradation of heme.

There also may be more direct interactions between the P-450 and heme regulatory systems. It has been proposed that P-450 induction is contingent upon increases in ALAS activity. Poland and Glover (73) found identical structure/activity relationships for both ALAS and AHH induction for a series of 15 dioxin congeners. However, $\mathrm{AHH}$ induction was more sensitive to lower doses and exhibited a different dose response curve. Cycloheximide repressed 
ALAS induction totally, while only partially suppressing AHH induction, indicating that AHH induction is NOT dependent upon ALAS induction and subsequent heme synthesis. In addition, $\mathrm{MC}$ induced $\mathrm{AHH}$, but had little effect on ALAS. May et al. (86) have recently postulated another hypothesis: that the xenobiotics that induce ALAS do so only indirectly, through induction of P-450 synthesis. According to this model, induction of P-450 apoprotein depletes the cellular heme pool, which is usually sufficient to repress heme synthesis. When heme is incorporated into the new P-450s, its "free" levels fall below a critical point and ALAS is derepressed. Interestingly, allylisopropyl acetamide (AIA) and 3,5-diethoxy carbonyl-1,4-dihydro-2,4,6-trimethyl pyridine (DDC) do not induce ALAS in steroidogenic tissues, where xenobiotics do not induce P-450s. If May and co-workers are correct, this is simply due to the fact that because of lack of apoprotein synthesis, no extra heme is needed. The actual in vivo mechanism is probably more complex than May et al. (86) postulate. Although all xenobiotic ALAS inducers may also induce P-450(s), not all xenobiotic P-450 inducers also induce ALAS (e.g., as mentioned above, $\mathrm{MC}$ is a potent inducer of $\mathrm{P}_{1} 450$, but not of ALAS). In addition, Hamilton et al. (88) found that 2-propyl-2-isopropylacetamide induced ALAS mRNA prior to induction of P-450 mRNA in cultured chick embryo hepatocytes, and treatment of chick embryos with glutethimide induced ALAS and P-450 mRNAs simultaneously. Therefore, at least in this system, induction of P-450 apoprotein is not necessary for induction of ALAS by xenobiotics.

There are also conflicting reports on the ability of heme to exchange between different microsomal P-450s (e.g., Sadano and Omura, 83). Treatment with cycloheximide inhibited protein synthesis (and thus inhibition of amino acid labels into PB and MC P-450s), while incorporation of labeled ALA into P-450 
heme continued. Thus, heme incorporation is not always coupled to P-450 synthesis. In a further study, pre-labeled heme was incorporated into newly induced P-450s. Other studies showed a strong correlation between heme and apoprotein synthesis, with no evidence of excess of either (e.g., Meier et al., 84). P-450 apoproteins may be degraded more rapidly than the holoenzyme. Thus, heme availability (concentration in the intracellular free heme pool) or switching of heme moieties between P-450 species may affect P-450 turnover. Parkinson et al. (83a) found that the apoprotein moiety has a shorter half-life than the heme moiety, supporting the argument that heme can be recycled. (Others have observed the opposite trend, see Chapter 5.)

Mechanism-based inactivation of P-450s often leads to N-alkylation of the P-450 heme cofactor and its subsequent loss. A recent review (Marks et al., 88) placed porphyrinogenic chemicals into three groups. Members of the first group (e.g., DDC) inhibit ferrochelatase by the accumulation of protoporphyrins, presumably due to interaction of DDC with P-450 and alkylation of the P-450 heme moiety. Members of the second group (e.g., AIA) interact with P-450, resulting in alkylation of heme nitrogen and formation of an AIA-porphyrin adduct (with no ferrochelatase inhibitory capacity). The decline in the free heme pool may result from a "cascade:" apoprotein combines with fresh heme, which is attacked by AIA and destroyed, P-450 is reconstituted with new heme, which is again destroyed, etc., until the heme pool is diminished and ALAS is turned on. The final group, represented by the PHAHs (polyhalogenated aromatic hydrocarbons), is involved in inhibition of uroporphyrinogen decarboxylase.

It is obvious from the foregoing discussion that interactions between heme and P-450 apoproteins, as well as heme and P-450 inducers and inhibitors and other regulators, can be very complex. Despite intensive investigation, the 
picture is far from clear in mammalian or avian systems. These questions have been hardly considered in teleost species; some background on general protein turnover and heme metabolism, including what little is known about these relationships in fish P-450 systems, is described in Chapter 5.

Molecular Evolution of P-450s

As more information becomes available about various P-450 primary sequences, whether obtained directly from amino acid sequencing of purified proteins or derived from cDNA nucleotide sequences, attempts to identify conserved domains and assign them functions continue. Use of primary sequence information to model tertiary structure has proven difficult. For example, hypotheses estimating the number of P-450 segments that span eukaryotic membranes have ranged from 1 to 12 segments (e.g., Nelson and Strobel, 88). Theories of the origin and evolution of P-450s continue to be refined. In the most thorough evolutionary comparison of P-450s published thus far, Nelson and Strobel (87) generated similar phylogenetic trees from two forms of analysis of 34 sequences. The results indicated that the major divisions of P-450 genes occurred as follows: the eukaryotic and prokaryotic forms separated about 1,400 Mybp (million years before the present), endogenous and drug-metabolizing P-450s separated about 900 Mybp, and the PB and MC families split about 800 Mybp. These and other authors feel that gene duplication has played an important role in the divergence of P-450 genes (Nelson and Strobel, 87; Adesnik and Atchison, 86). In general, these analyses have utilized P-450 sequences from mammals and one or two other species (e.g., a few bacterial and one avian sequence). Thus, firm conclusions as to the origin and relationships between the different forms of P-450s will only be reached after other nonmammalian - and nonvertebrate $\mathrm{P}-450 \mathrm{~s}$ are added to the database. 
Although P-450cam (P450CIA1), the soluble camphor-metabolizing isozyme from Pseudomonas putida, has been studied in great detail and is the only P-450 to date which has been successfully crystallized (Poulos et al., 1985), analysis of other prokaryotic or lower eukaryotic P-450s has lagged behind. Recently, P-450s from yeast (Sanglard et al., 87; Aoyama et al., 87), from bacteria, and from a few lower vertebrates (chick: Hobbs et al., 86; trout: Heilmann et al., 88) have been described or should appear shortly in the literature (housefly: Nebert and coworkers (Louisiana meeting)). Molecular manipulations, such as cleavage of the hydrophobic amino-terminal end of the coding region prior to over-expression in bacterial or yeast hosts, may lead to crystallization of a truncated eukaryotic protein, but questions concerning the actual structure of the enzyme and its interactions with the membrane and membrane-bound components of the MFO system will still remain. As the comparative biochemistry of P-450s branches out further into "non-traditional" species, we should gain further insights into the possible origins and evolutionary relationships of these widely distributed proteins.

\section{REVIEW OF THE TELEOST LITERATURE}

\section{$\underline{\text { P-450s in Aquatic Animals }}$}

Many freshwater and marine organisms have been analyzed for the involvement of MFO systems in xenobiotic biotransformations. Activities in invertebrates are generally very low (Stegeman, 81 and 85; Stegeman and Kloepper-Sams, 87), and most studies have focused on aquatic vertebrates, particularly teleosts. The majority of MFO activity in fish is localized in the hepatic tissue, with lesser amounts in the heart, kidney, adrenals and gonads (Stegeman, 81; Stegeman et al., 82; Williams et al., 84; Pesonen and 
Andersson, 87). As in mammals, the hepatic MFO systems of fish are oxygenand NADPH- dependent and are localized in the ER fraction. They consist of a flavoprotein, NADPH-cytochrome P-450 reductase, and a membrane-bound heme protein, cytochrome P-450. Cytochrome $b_{5}$ has an obligate role in the function of some fish isozymes, stimulating some activities but having no detectable effect on others (Klotz et al. 83 and 86).

Teleost P-450s are inducible. Catalytic activities associated with P-450s can be stimulated in many species by exposure to MC-type compounds, including BP, BNF, MC and "MC-type" PCB congeners (Statham, et al., 78; Spies et al., 82; Stegeman, 81; Gooch et al., submitted, and references therein). A [35-S]methionine labeling study showed that there is increased synthesis of microsomal proteins in trout exposed to $150 \mathrm{mg} / \mathrm{kg}$ BNF, indicating that increases in enzyme activity may be due to true induction rather than to activation of existing proteins (Vodicnik et al., 84). However, P-450 proteins were not specifically identified in that study. Results of a representative induction study (Andersson et al., 85) in juvenile rainbow trout are shown below. 
Treatment

EROD Activity

Fold Increase

$\mathrm{nmol} / \mathrm{min} / \mathrm{mg}$

Over Control Values

control

$0.022 \pm 0.010^{\mathrm{a}}$

BNF

$3.78 \pm 1.74$

172

control

$0.018 \pm 0.011$

Clophen A50

$0.88 \pm 0.47$

49

aFor each group, $N=5$. All values represent the mean $\pm s d$.

bClophen A50 is a commercial PCB mixture, similar to the American Aroclor mixtures.

Vodicnik et al. (84) saw induction of a similar magnitude in rainbow trout, with $150 \mathrm{mg} / \mathrm{kg}$ BNF eliciting a 15-fold increase in ethoxycoumarin O-deethylase (ECOD) activity and a 93-fold increase in EROD activity in comparison to controls after 48 hours.

In teleosts treated with MC-type inducers, a 20-fold induction of beno[a]pyrene metabolism (BP is the $\mathrm{AHH}$ substrate, so the catalyst is also called benzo[a]pyrene hydroxylase $[\mathrm{BPOH}])$ can occur. Förlin (80) measured a 27-fold induction of $\mathrm{BPOH}$ activity after MC treatment and a 23-fold induction after Clophen A50 treatment of juvenile rainbow trout. Interestingly, reductions in $\mathrm{BPOH}$ activity followed PCN and PB treatment in these animals. In a comparative study, Stegeman et al. (81) achieved approximately 20 -fold induction of BPOH activity in croaker (Micropogon undulatus) and rainbow trout treated with BP and MC, respectively. Scup, on the other hand, exhibited much less induction. The 
scup used in this experiment, however, had much higher BPOH control values $(0.250 \mathrm{nmol} / \mathrm{min} / \mathrm{mg})$ than did the croaker and trout $(0.026$ and 0.011 $\mathrm{nmol} / \mathrm{min} / \mathrm{mg}$, respectively). It has been suggested that many scup are environmentally induced such that "control" values obtained from untreated feral fish represent previous induction (Stegeman and Binder, 79). Healthy scup maintained for several months to two years on "clean" Nantucket Sound water have much lower microsomal EROD activity levels than do freshly-caught fish (B.R. Woodin, P.J. Kloepper-Sams, and J.J. Stegeman, unpublished observations), substantiating this view.

In general, fish seem to be more sensitive to MC-type inducers than mammals, induction being stronger and more persistent. Vodicnik and coworkers (84) saw maximal ECOD and EROD activities 48 hours after BNF treatment, with maintenance of this level at 72 hours. In Andersson et al.'s study mentioned above (85), EROD activities peaked 3 (BNF) and 7 (Clophen 50) days after treatment of rainbow trout held at 10 to $12{ }^{\circ} \mathrm{C}$, with conjugating enzymes achieving maximal induction even later. Season or temperature can influence the timing of induction in these poikilotherms. James and Bend (80) treated sheepshead with $10 \mathrm{mg} / \mathrm{kg} \mathrm{MC}$ during the summer (water temp. $26^{\circ}$ ) and winter (water temp. $14^{\circ}$ ). Maximal $\mathrm{BPOH}$ activity was reached 3 days after treatment in the summer, with a return to control values by 14 days. It took 8 days to achieve maximal $\mathrm{BPOH}$ activity following the winter treatment, with levels still elevated after 28 days. The extent, but not the magnitude, of induction was similar in the two experiments. All marine fish tested by James and Bend (80) exhibited no response in epoxide hydrolase (EH), glutathione (GSH) transferase, or reductase activities, although Stegeman (81) found some reductase induction. 
Several studies have linked PAH-related MFO activity in fish with possible consequences such as tumorogenesis or the formation of toxic metabolites. In rainbow trout, a constitutive P-450, LM2, activates aflatoxin B1 (Williams and Buhler, 83). Hepatic microsomes from untreated trout can catalyse the metabolism of BP to intermediates that bind DNA at rates 3 to 4 times greated than those of untreated rat microsomes (Ahokas et al., 79). The predominant BP adduct appears to be the ultimate carcinogen (Nishimoto and Varanasi, 85). In studies of BP activated in fish cell cultures, Smolarek et al. (87) found that the major BP-DNA adduct formed resulted from the reaction of (+)-anti-BP-7,8-diol9,10 epoxide with deoxyguanisine. The authors conclude that while BP can be metabolized to the ultimate carcinogen by these cells, the level of binding of the metabolite to DNA is lower ( $<5 \mathrm{pmol} \mathrm{BP/mg} \mathrm{DNA} \mathrm{in} \mathrm{BF-2} \mathrm{cells)} \mathrm{than} \mathrm{found} \mathrm{in}$ comparable studies with rodent embryo cells ( $>30 \mathrm{pmol} \mathrm{BP} / \mathrm{mg}$ DNA). Fish cells also showed more efficient conjugation of the BP 7,8 diol, making less material available for formation of the ultimate carcinogen.

An important distinction between the teleost and mammalian systems is the apparent lack of response in fish to phenobarbital. Although a few reports have indicated that fish respond to PB-type compounds (Pohl et al., 74; Burns, 76; Verdina et al., 1987), the data are inconclusive and more thorough studies have found no evidence of a strong or consistent response (Bend et al., 73; Schwen and Mannering, 82; Melancon et al., 85; Förlin, 80; Vodicnik et al., 84; Elskus and Stegeman, in press). Phenobarbital does enter the animal and can be metabolized, so the lack of response is not due to "nonexposure." Because little is known about the mechanism of PB induction in mammals, even after extensive study, it is difficult to determine the cause of a lack of inducibility in fish. Lower vertebrates may not have the structural genes for PB-inducible P-450s, or the 
expression of these proteins may be blocked at some stage. Alternatively, the structural genes may be constitutively expressed: untreated fish can catalyze activities known to be PB-inducible in mammals, such as benzphetamine $\mathrm{N}$-demethylation. These activities may be due in part to MC-type isozymes, which are already partially induced in feral fish.

The effects of other known mammalian P-450 inducers have not been widely investigated in teleosts, although a few studies have appeared. Decreases in trout $\mathrm{AHH}$ and p-nitroanisole O-demethylase activities occurred after treatment with the synthetic steroid PCN, although spectral P-450 content remained unchanged (Förlin, 80). Possibly some other isozyme(s), which catalyzes the

metabolism of substrates different form those examined by Förlin, was induced by PCN treatment. Stegeman and co-workers obtained inconclusive results in scup treated with isosafrole, the most potent inducer of mammalian P450IA2 (unpublished observations). Goksøyr (86) suggested that while phenanthrene induces the $58 \mathrm{kD}$ BNF-inducible P-450 protein (the P-450E orthologue) in cod (Gadus morhua), PCN induces a unique $59 \mathrm{kD}$ hemoprotein.

Molecular Aspects and Regulation of Teleost MFOs

The molecular aspects of $\mathrm{P}-450$ induction in aquatic species have not been addressed until recently. Most studies characterize enzyme activities and attempt to correlate the level and type of activity induced with environmental conditions or chemical exposure in the laboratory. Protein purification and reconstitution under defined conditions, antibody production and utilization, and molecular cloning techniques are increasingly being employed in order to more rigorously answer questions of xenobiotic induction and its regulation in aquatic animals. 
Isolation of teleost P-450 isozymes has been achieved by few research groups. Buhler and co-workers have isolated 4 or 5 liver microsomal P-450s from rainbow trout (Williams and Buhler, 82 and 84), and Stegeman's group has isolated 5 fractions from scup (Klotz et al., 83). Goksøyr (85) has partially purified 4 cod P-450 forms. The activities of these purified P-450s have been examined with only a restricted suite of substrates, but trends of $\mathrm{AHH}$ and steroid metabolism are becoming clear. Some characteristics of purified teleost P-450s are shown in Table 1-3.

Chromatography of solubilized, ammonium sulfate-fractionated, scup hepatic microsomes on an anion exchange column resulted in the separation of several P-450 isozymes (Table 1-3), the fifth major peak eluting being P-450E (Klotz et al., 83). This $54.3 \mathrm{kD}$ heme-containing protein has an absorption maximum at $447 \mathrm{~nm}$ and is the major aryl hydrocarbon hydroxylase in scup liver microsomes. P-450E is inducible by the MC-type compound BNF, and $\mathrm{AHH}$ and EROD activities have been reconstituted using this enzyme (Klotz, et al., 83). Reconstituted P-450E, in the presence of purified epoxide hydrolase, forms benzo[a]pyrene metabolites that are nearly $40 \%$ trans-7,8-dihydrodiol, the precursor of the ultimate carcinogen, (+)7,8-dihydrodiol-9,10-epoxide (Stegeman and James, 85).

In a comparative study of $\mathrm{AHH}$ induction and $A h$ receptors in selected nonmammalian species, only chicks exhibited both $\mathrm{AHH}$ induction and a specific TCDD-binding peak (Denison et al., 85). Quail had no detectable $A h$ receptor, despite induction of AHH activity similar to that of the chick. Rainbow trout showed minimal inductive response, and no indication of an $A h$ receptor. Additional studies with trout and scup cytosols also provided no indication of an 
TABLE 1-3: Teleost Hepatic P-450s: Physical Properties and Catalytic Activities

\begin{tabular}{clll} 
Isozyme & $\begin{array}{c}\lambda \text { max, } \\
n m\end{array}$ & $\begin{array}{c}\mathrm{M}_{\mathrm{r},} \\
\times 1000\end{array}$ & \multicolumn{1}{c}{ Major Characteristics } \\
\hline Scup $^{\mathrm{a}}$ & & & \\
P-450A & 447.5 & 52.7 & testosterone 6B-OH, ECOD \\
P-450B & 449.5 & 45.9 & tentative 15-alpha-OH \\
P-450C & 450 & $49-51$ & \\
P-450D & 451 & 50 & \\
P-450E & 447 & 54.3 & EROD and AHH, ECOD \\
Rainbow trout $^{\mathrm{b}}$ & & & \\
\hline LM1 & 449 & 50 & \\
LM2 & 449.5 & 54 & lauric acid OH, aflatoxin activator \\
LM3 & 447.5 & 56.5 & \\
LM4a & 447 & 58 & AHH, EROD \\
LM4b & 447 & 58 & AHH, EROD \\
Cod & & & \\
\hline P-450a & 447.5 & 55 & no EROD \\
P-450b & 447.5 & 54 & no EROD \\
P-450c & 448 & 58 & EROD \\
P-450d & 448 & 56 & EROD \\
\hline
\end{tabular}

a(Klotz et al., 83 and 86 )

b(Williams and Buhler, 83 and 84)

$c($ Goksøyr, 85). The only enzyme activity examined was EROD.

dOrthologues of P-450E are P-450c (rat), $\mathrm{P}_{1} 450$ (mouse), LM4 (trout), P-450c (cod). 
$A h$ receptor (Hamilton, etc, unpublished results). A recent report from Nebert's laboratory, however, indicates that a TCDD-binding peak is present in untreated rainbow trout liver cytosols (Heilmann et al., 88). This peak, as measured by sucrose density gradient centrifugation of cytosol preincubated with radiolabeled TCDD (Okey et al., 79), is saturable and can be displaced by the presence of 100fold excess of MC or TCDD. The authors estimate the concentration of the moiety to be $7.5 \mathrm{fmol} / \mathrm{mg}$ cytosolic protein, similar to that they previously measured in some strains of $A h$-responsive mice (reference cited in Heilmann et al., 88). Further details of the biochemical and physical properties of this moiety should provide insight into its possible role in the regulation of nonmammalian P450IA1 expression.

In an extension of their earlier studies on the mouse PAH-binding protein, Marletta and coworkers sought a PAH-binding protein in other species. They found binding activity in all species tested: rat, chicken, guinea pig, scup, and rabbit (Barton and Marletta, 88). The scup equilibrium binding constant $\left(\mathrm{K}_{\mathbf{d}}=\right.$ $10.9 \pm 2.3 \mathrm{nM})$ was similar to that of the rat $\left(\mathrm{K}_{\mathrm{d}}=8.9 \pm 1.6 \mathrm{nM}\right)$, higher than mouse, but lower than that of chicken or guinea pig. The concentration of binding sites in scup ( $\mathrm{B}_{\max }=8.6 \pm 0.8 \mathrm{pmol} / \mathrm{mg}$ protein $)$ was similar to that in the mouse $\left(B_{\max }=6.3 \pm 0.3 \mathrm{pmol} / \mathrm{mg}\right.$ protein). The PAH-binding site could not be competed for by the TCDD analog 2,3,7,8-tetrachlorodibenzofuran (TCDBF) in any of the cytosols, confirming that this protein is a moiety distinct from the $A h$ receptor. Scup exhibited a particularly high level of non-specific binding, which the authors speculate may indicate the presence of other, low affinity binding sites. As mentioned previously, the function of the PAH-binding protein is not known. 


\section{Environmental Monitoring}

Because aquatic organisms have been found to be sensitive to exposure to environmental pollutants such as BP, petroleum-derived hydrocarbons, and polychlorinated biphenyls, suggestions have been made for the use of these organisms, especially fish, in environmental monitoring studies (Förlin, 80; Payne, 84; Neff, 85). Various analyses, including MFO activities, have been suggested as possible monitoring tools. Some studies have attempted to link P-450 induction with reproductive effects (Spies et al., 88a and 88b). P-450 induction is dependent on a sometimes bewildering variety of factors including temperature, diet, route of uptake, time and concentration of exposure, presence of other chemicals (possible synergists or suppressors of induction), sex, age, developmental stage, etc. While I do not directly address questions of environmental monitoring in this thesis, the methods developed and described in the following chapters such as immunoblotting and mRNA quantitation can be applied to environmental situations (e.g., Stegeman et al., 86, 87 and 88; Haasch

et al., submitted) The application of these techniques will enhance our understanding of P-450E induction in individuals exposed to different environmental conditions.

\section{GENERAL AIMS OF RESEARCH AND SPECIFIC QUESTIONS}

In order to accurately assess the impact of environmental chemicals on the monooxygenase system, which may deactivate these compounds or activate them to deleterious reactive intermediates, it is necessary to understand the role induction plays in the regulation of this enzyme system. The wealth of background information on the enzyme itself and the availability of antibody probes for identification and measurement of $\mathrm{P}-450 \mathrm{E}$ protein and mRNA levels led 
me to examine the mechanism of regulation of the xenobiotic-metabolizing isozyme P-450E. Originally, I planned to examine P-450E in scup, but various logistic problems resulted in a change of focus to its homologue, which shall also be called P-450E throughout this thesis, in another teleost, the marsh minnow or mummichog Fundulus heteroclitus. Fundulus was selected because of the availability of individuals from non-migratory populations found in relatively "clean" habitats throughout most of the year, and the ease of maintaining and treating large numbers of fish. We also have a good deal of background on the physiology of these well-studied animals (American Zoologist, 86) and on the basics of the MFO system in Fundulus (Stegeman, 79; Binder and Stegeman, 80; Binder and Stegeman, 84; Binder et al., 85). The specific questions which I addressed in attempting to understand the regulation of P-450E in Fundulus included the following:

1) What is the temporal pattern of induction of microsomal P-450E-related activity in Fundulus heteroclitus after exposure to the MC-type inducer BNF?

2) Does this increase in activity correspond to increases in the P-450E protein levels?

3) What are the mechanisms of this induction?

a) Is P-450E-specific mRNA increased?

b) If so, what is the temporal relationship between protein, activity and mRNA increases? 
4) What are the turnover rates of protein and heme following exposure to BNF in Fundulus heteroclitus?

Prior to addressing these questions, I examined the feasibility of utilizing anti-scup P-450E antibodies as probes in the study of regulation, and characterized them in more depth. The main questions concerning the antibodies were:

1) What is the specificity of the monoclonal and polyclonal antibodies generated against scup P-450E?

2) What is the cross-reactivity of the monoclonal and polyclonal antibodies with the species generally studied in the lab, as analyzed by

- immunochemical detection

- catalytic inhibition

Chapter 2 describes the published results of investigations of the latter questions, setting the stage for the use of the antibodies in Chapters 3,4 , and 5 , which discuss results of the induction studies. Chapter 3 emphasizes the induction of P-450E protein and EROD activity following BNF treatment, and Chapter 4 examines the relationships between protein and mRNA levels following BNF treatment. Chapter 5 explores some questions concerning turnover of protein and heme in fish (total, microsomal and P-450E) following treatment with BNF. Chapter 6 briefly summarizes the findings reported in Chapters 2 through 5 , and provides some speculations on possible future research directions. 
CHAPTER 2: SPECIFICITY AND CROSS-REACTIVITY OF MONOCLONAL AND POLYCLONAL ANTIBODIES AGAINST CYTOCHROME P-450E OF THE MARINE FISH SCUP (reprint)

PREAMBLE $\quad 52$

INTRODUCTION 57

MATERIALS AND METHODS 58

$\begin{array}{ll}\text { Animals } & 58\end{array}$

$\begin{array}{lr}\text { Treatment } & 58\end{array}$

Enzyme preparation and activity assays $\quad 58$

Antibody production and characterization $\quad 59$

Immunoblot analysis $\quad 59$

RESULTS $\quad 59$

Isozyme specificity $\quad 59$

$\begin{array}{lr}\mathrm{P}-450 \mathrm{E} \text { in microsomes } & 60\end{array}$

Cross-reactivity among teleosts $\quad 60$

Cross-reactivity with mammals $\quad 62$

Catalytic inhibition $\quad 62$

P-450E in untreated fish $\quad 62$

DISCUSSION 64

REFERENCES $\quad 66$

$\begin{array}{ll}\text { AFTERWORD } & 68\end{array}$ 


\section{PREAMBLE}

In order to further our studies on the presence and regulation of P-450E protein in teleost species, we colloborated with Drs Harry V. Gelboin and Sang S. Park of the National Cancer Institute, NIH, in the production of monoclonal antibodies (MAbs) against the purified isozyme. Dr. Gelboin has been interested in developing a suite of MAbs for use in purification and characterization of P-450 isozymes from various species (Cheng et al., 84; Park et al., 86b; Waxman et al., 87). In this case, BALB/c female mice were immunized with $\mathrm{P}-450 \mathrm{E}$ purified by Alan Klotz (Klotz et al., 83) and their spleen cells fused with SP2/OAg14 myeloma cells. The production and preliminary characterization of the MAbs is described in Park et al. (86a).

Nine hybridomas produced MAbs that strongly recognized P-450E in radioimmunoassays (RIA). Four of these nine hybridomas produced antibodies which produced precipitin reactions with scup $\mathrm{P}-450 \mathrm{E}$ in double immunodiffusion (Ouchterlony) analysis. None of the anti-scup P-450E antibodies could immunoprecipitate any of the purified mammalian P-450 forms tested (rat PB-B [P-450b], rat MC-B and BNF-B [the latter both P-450c, but from two different laboratories]; rabbit form 2 [PB-inducible, orthologue to rat P-450b]; and rabbit form 4 [MCinducible, orthologue to rat P-450d]). Ouchterlony immunodiffusion analysis is dependent on lattice formation, which may not occur with some (most) monoclonal antibodies. Thus, the MAbs were also examined for cross-reactivity with mammalian P-450s with solid-phase RIA. (The mammalian P-450s were bound to a plate and the MAb to be tested was added. Radiolabeled rat anti-mouse Ig kappa (light chain) antibodies were added and the amount of radioactivity was

measured.) In this analysis, one of the anti-scup antibodies, MAb 1-12-3, 
recognized purified rat MC-B and BNF-B. MAb 1-12-3 was also able to inhibit the AHH activity of reconstituted rat BNF-B.

The following publication describes the further characterization of several of the monoclonal antibodies generated by Dr. Sang Park, as well as some antiP450E polyclonal antibodies (PAbs) generated at the Animal Care Facility at MIT, by using immunoblot ("Western" blot) analysis. This method requires more conventional techniques (no radiolabeled antibodies need be generated) than does the RIA, and provides information on the number and molecular weight of proteins recognized, rather than lumping all cross-reactive proteins together. I examined the specificity of the antibodies in reactions with all purified and partially-purified P-450 forms available from scup hepatic microsomes. All monoclonals and polyclonals tested reacted solely with the antigen, P-450E, and with no other purified isozyme or isozyme fraction from scup.

I then examined scup microsomal samples, which contain a multitude of proteins besides the $\mathrm{P}-450$ s (including proteins possibly present in trace amounts in the antigen preparation). The monclonal antibodies, as expected, were highly specific for P-450E. The polyclonal antibodies recognized P-450E, but also reacted weakly with some other microsomal proteins. The signal from the nonP-450E proteins remained constant in microsomal samples from scup treated with vehicle only or with various inducers despite marked increases in the P-450E band, indicating that these non-inducible proteins are recognized because they were minor contaminants of the antigenic mixture. Because the content of these cross-reacting proteins was approximately constant in variously induced samples, and they did not migrate near or with P-450E, the PAb could still be used for immunoquantitation of P-450E. 
I also investigated microsomal preparations from a number of other teleosts for cross-reactivity of the antibodies with P-450E orthologues. Immunoblotting of preparations from various species with anti-P450E antibodies allows for a highly specific analysis of P-450E protein content without the tedious purification of $\mathrm{P}-450$ protein from each species and antibody generation against each purified protein. This is especially important in cases where only a small amount of tissue is available, either due to the small size of the organism (e.g., Fundulus) or the difficult logistics of obtaining a large number of individuals (e.g., species such as the deep-sea rattail Coryphanoides armatus, Stegeman et al., 86) or when numerous species are to be examined (e.g., Bermuda species, Stegeman and Woodin, manuscript in preparation). Microsomes from all teleost species examined here, including rainbow trout, brook trout, winter flounder and Fundulus, exhibited a single reactive band in immunoblots incubated with MAb 1-12-3.

Like the MAbs, the anti-scup P-450E polyclonal antibodies also gave a highly specific reaction with the P-450E orthologues. Reaction of the PAbs with other, non-P-450 teleost microsomal proteins was decreased compared to that observed in scup microsomes. This is possibly due to a different distribution of these cross-reacting proteins in other species, or to increased structural changes in these other proteins compared to the apparent close relationship of the P-450E homologues (see section on amino-terminal scup and trout sequences, Chapter 3 Discussion and Table 3-5). Because isolated proteins were not available from any species besides scup, scup P-450E served as a standard in all cases. Differences in teleost primary sequences may affect the affinity of the antibody for the P-450E orthologue in each individual species. Thus, $\mathrm{P}-450 \mathrm{E}$ protein values must be 
considered on a relative basis within each species and cannot be directly compared across species lines.

Cross-reactivity of the anti-scup antibodies with mammalian tissue was also examined. As noted above, MAb 1-12-3 recognizes purified rat P-450c in RIA; this finding was confirmed by recognition in immunoblots. Surprisingly, the monoclonal antibody (which recognizes a single band in scup and all other teleost microsomes tested thus far) recognizes two bands in induced rat microsomes: one band which co-migrates with purified P-450c (rat P450IA1) and another, fainter band with a lower apparent molecular weight. This band, or a comigrating one, is actually recognized more strongly than is P-450c by one of our polyclonal antibody preparations. In an attempt to establish the identity of the lower $\mathrm{M}_{\mathrm{r}}$ band, I immunoblotted rat microsomes with MAb 1-7-1, a monoclonal antibody generated against rat P-450c from Dr. Gelboin's laboratory which recognizes both $\mathrm{P}-450 \mathrm{c}$ and $\mathrm{P}-450 \mathrm{~d}$ (Cheng et al., 84) side by side with the polyclonal antibody. P-450d (P450IA2), as recognized by MAb 1-7-1, comigrated with the PAb cross-reactive band.

Inhibition of specific enzyme activities is another characteristic of some antibody-antigen interactions. The preliminary report on the MAbs showed that some of them could inhibit AHH and ECOD activities (Park et al., 86a). I found that MAb 1-12-3 inhibited EROD activity in induced scup, brook trout and rainbow trout microsomes to less than $10 \%$ of the EROD activity observed in the presence of a non-specific MAb. The polyclonal antibodies inhibited scup microsomal EROD and AHH by over $90 \%$, inhibited about $60 \%$ of ECOD activity, and had no effect on aminopyrine $\mathrm{N}$-demethylase (ApND) activity. This pattern is consistent with our knowledge of $\mathrm{P}-450 \mathrm{E}$ catalytic function: it is the 
major (and possibly sole) EROD and AHH catalyst, it is one of at least two ECOD catalysts, and it is not directly involved in ApND activity. 
ARCHIVES OF BIOCHEMISTRY AND BIOPHYSICS

Vol. 253, No. 1, February 15, pp. 268-278, 1987

Reprinted with permission from Acadenic Press, Inc.

Specificity and Cross-Reactivity of Monoclonal and Polyclonal Antibodies against Cytochrome $P-450$ E of the Marine Fish Scup ${ }^{1}$

\author{
PAMELA J. KLOEPPER-SAMS, ${ }^{*, 2}$ SANG S. PARK, $†$ HARRY V. GELBOIN, $\dagger$
} AND JOHN J. STEGEMAN*

*Department of Biology, Woods Hole Oceanographic Institution, Woods Hole, Massachusetts 02543, and $\dagger$ Laboratory of Molecular Carcinogenesis, National Cancer Institute, National Institutes of Health, Bethesda, Maryland 02892

Received September 22, 1986

Monoclonal antibody (MAb) 1-12-3 generated against liver cytochrome $P$-450E $(P$ $450 \mathrm{E}$ ), an aryl hydrocarbon hydroxylase of the marine fish Stenotomus chrysops (scup), reacted only with $P-450 \mathrm{E}$ when tested in immunoblot analysis with five $P-450$ fractions from scup liver. This and six other MAbs against $P-450 \mathrm{E}$ recognized purified $P-450 \mathrm{E}$, as well as a single band in $\beta$-naphthoflavone (BNF)-induced scup microsomes that comigrated with authentic $P-450 \mathrm{E}$. Like MAb $1-12-3$, polyclonal anti- $P-450 \mathrm{E}$ reacted with $P-450 \mathrm{E}$ but not with other scup $P-450$ fractions and reacted strongly with a band coincident to $P-450 \mathrm{E}$ in BNF-treated scup microsomes. However, the polyclonal antibody $(\mathrm{PAb})$ also faintly recognized additional microsomal proteins. MAb 1-12-3 recognized $P-450 \mathrm{E}$ induced by $3,3^{\prime}, 4,4^{\prime}, 5,5^{\prime}$-hexachlorobiphenyl and by polychlorinated biphenyl mixtures in scup, and a single band induced by BNF or 3-methylcholanthrene (MC) in microsomes of other teleosts, including two trout species, killifish and winter flounder. The content of the $P-450 \mathrm{E}$ counterpart in these fish and also in untreated scup coincided with induced ethoxyresorufin $O$-deethylase (EROD) activity. Induced EROD activity in scup and trout was strongly inhibited by MAb 1-12-3, further demonstrating the relationship between $P-450 \mathrm{E}$ and induced $P-450$ in trout. MAb 1-12-3, two other MAbs, and anti- $P-450 \mathrm{E}$ PAb recognized a band comigrating with $P-450 \mathrm{c}$ in BNF-induced rat microsomes. MAb 1-12-3 also recognized purified rat $P-450 \mathrm{c}$. MAb 1-12-3 and anti- $P-450 \mathrm{E}$ $\mathrm{PAb}$ recognized a second band of lower molecular weight than $P-450 \mathrm{c}$ in $\mathrm{BNF}$ rat microsomes which may correspond to $P-450 \mathrm{~d}$, the MC- and isosafrole-inducible rat isozyme. The results firmly establish the identity of scup $P-450 \mathrm{E}$, the relationship of BNF-induced $P-450$ in other teleosts with $P-450 \mathrm{E}$, and the immunochemical relationship of $P-450 \mathrm{E}$ with rat $P-450 \mathrm{c}$. Furthermore, results with untreated fish suggest that effects of environmental chemicals may be detected by immunoblotting with monoclonal anti- $P-450 \mathrm{E}$.

(c) 1987 Academic Press, Inc.

The $P-450$ cytochromes are a family of related enzymes which catalyze the transformation of a variety of substrates, from endogenous steroids and fatty acids to xenobiotics such as polynuclear aromatic hydrocarbons $(\mathrm{PAH})^{3}(1)$. Vertebrates from

\footnotetext{
${ }^{1}$ Some of these results have appeared in preliminary form in (1986) Fed. Proc. 45, 320.

${ }^{2}$ To whom correspondence should be addressed.

${ }^{3}$ Abbreviations used: $\mathrm{AHH}$, aryl hydrocarbon hy-

fish to mammals have been established as having multiple forms of $P-450$ (2). The

droxylase; BNF, $\beta$-naphthoflavone; ECOD, ethoxycoumarin $O$-deethylase; ELISA, enzyme-linked immunosorbent assay; EROD, ethoxyresorufin $O$-deethylase; HCB, hexachlorobiphenyl; HRP, horseradish peroxidase; MAb, monoclonal antibody; MC, 3-methylcholanthrene; PAb, polyclonal antibody; $\mathrm{PAH}$, polynuclear aromatic hydrocarbon; PBS, phosphatebuffered saline; $\mathrm{PCB}$, polychlorinated biphenyl. 
functions of the $P-450 \mathrm{~s}$ in fish are only now being established. Three highly purified forms, $P-450 \mathrm{~s} \mathrm{~A}, \mathrm{~B}$, and $\mathrm{E}$, have been isolated from hepatic microsomes of Stenotomus chrysops (scup), a North Atlantic coastal fish. Reconstituted scup $P-450 \mathrm{~A}$ is a major steroid hydroxylase (3) and $P-450 \mathrm{E}$ is the major aryl hydrocarbon hydroxylase $(\mathrm{AHH})$ in this fish $(4,5)$.

$P-450 \mathrm{E}$ is of special interest because of its potential for activation of $\mathrm{PAH}$ procarcinogens. When reconstituted with epoxide hydrolase, lipid, and $P-450$ reductase, this enzyme forms benzo[ $a]$ pyrene metabolites that are nearly $40 \%$ trans-7,8-dihydrodiol (4), the precursor to the ultimate carcinogen of benzo $[a]$ pyrene, 7,8-dihydrodiol-9,10epoxide (6). Properties of $P-450 \mathrm{E}$ also suggest that it is the major PAH-inducible $P$ 450 form in scup. The isolated protein has a catalytic profile (inhibition by $\alpha$-naphthoflavone, high AHH activity), optical properties $\left(\mathrm{Fe}^{2+}-\mathrm{CO}\right.$ absorption maximum near $447 \mathrm{~nm}$ ), and a molecular weight $(54,000)$ consistent with $\mathrm{PAH}-i n d u c i b l e$, AHH-metabolizing forms (4). Experimental treatment of scup with 3-methylcholanthrene (MC) or $\beta$-naphthoflavone (BNF) induces increased levels of microsomal $\mathrm{AHH}$ and 7-ethoxyresorufin $\mathrm{O}$-deethylase (EROD) activities, a blue shift in the Soret peak of the $\mathrm{Fe}^{2+}-\mathrm{CO}$ complex, and specific increases in a $54-\mathrm{kDa}$ protein (7). These properties are similar to those characteristic of the major MC-inducible isozyme in rats, $P-450 \mathrm{c}$ (also called $P-450$ BNF-B $(8,9))$. Furthermore, some antibodies to rat $P$-450c specifically recognize scup $P$ $450 \mathrm{E}$ (3).

We recently described the generation of monoclonal antibodies to scup $P-450 \mathrm{E}$ (10), one of which (monoclonal antibody 1-12-3) strongly recognized rat $P-450 \mathrm{c}$ in radioimmunoassay and immunoblots. In the present study we examined the specificity of these monoclonal antibodies, as well as polyclonal antibodies against scup $P-450 \mathrm{E}$, employing immunoblots with both microsomes and purified isozymes. In addition, we analyzed the recognition of specific proteins in different species. This is the first reported use of monoclonal antibodies in immunoblotting to identify and quantitate
PAH-inducible $P-450$ forms in aquatic organisms. The results establish the presence of a closely related protein in scup and other fish species and confirm an immunochemical relationship, manifested by the presence of common epitopes, between the $\mathrm{BNF}$-inducible rat and the fish $\mathrm{P}-450$ isozymes.

\section{MATERIALS AND METHODS}

Animals. Scup (Stenotomus chrysops) were caught by angling in Nantucket Sound, Vineyard Sound, and Buzzards Bay, Massachusetts. Winter flounder (Pseudopleuronectes americanus) weighing 300 to $360 \mathrm{~g}$ and with developed gonads were collected by otter trawl in local waters off Woods Hole in January. Nonspawning killifish (Fundulus heteroclitus) were collected by seining in Sippewissett Marsh. Brook trout (Salvelinus fontinalis) were raised from eggs obtained from the Sandwich Fish Hatchery. Immature rainbow trout (Salmo gairdneri) were obtained from Thistle Springs Trout Farm (Ashton, Ontario) and maintained as before (7). Marine fish were maintained in flowing seawater and trout in flowing well water on a diet of Purina Trout Chow. The diet of the marine species was supplemented with chopped squid. Male Sprague-Dawley retired breeder rats were purchased from Charles River Breeding Labs (Wilmington, MA) and maintained on Rat Chow and water ad libitum.

Treatment. Experimental animals were injected ip with either BNF in corn oil or corn oil alone. Adult scup of both sexes (200 to $430 \mathrm{~g}$ ) that were gonadally regressed were treated with 35 to $75 \mathrm{mg} / \mathrm{kg}$ BNF; after 5 days livers were pooled and hepatic microsomes were prepared. Similarly, nonspawning adult brook trout of both sexes were treated with $50 \mathrm{mg} / \mathrm{kg}$ BNF and hepatic microsomes were prepared from pooled livers. Rainbow trout received $20 \mathrm{mg} / \mathrm{kg} \mathrm{MC}$ and 3 days later the fish were killed and liver microsomes were prepared. Female killifish ( 5 to $15 \mathrm{~g}$ ) were dosed with 50 $\mathrm{mg} / \mathrm{kg} \mathrm{BNF}$ and killed 3 or 7 days later. Scup were also treated with the $\mathrm{PCB}$ congener $3,3^{\prime}, 4,4^{\prime}, 5,5^{\prime}$-hexachlorobiphenyl at $40 \mathrm{mg} / \mathrm{kg}$, and with Aroclor 1254/ 1242 at $2 \mathrm{mg} / \mathrm{kg}$, as described elsewhere (11). Rats were dosed ip daily for 3 days with $80 \mathrm{mg} / \mathrm{kg}$ BNF and killed on the fourth day.

Enzyme preparation and activity assays. Livers were excised and microsomes from all animals were prepared according to established methods $(7,12)$. Scup $P-450$ fractions A through $\mathrm{E}$ were isolated as described elsewhere (4). $P$-450c purified from Long-Evans rats was a generous gift of Dr. Michael Marletta, MIT. The specific contents of cytochromes $b_{5}$ and $P-450$ were measured spectrally and by protein analysis $(12,13)$; AHH, EROD, and aminopyrine $N$-demethylase activ- 
ities were assayed by established procedures $(7,12$, 14). For catalytic inhibition studies, antibody was incubated with the preparation for $20 \mathrm{~min}$ on ice prior to reaction initiation by addition of NADPH.

Antibody production and characterization. Polyclonal antibodies were generated against purified scup hepatic $P-450 \mathrm{E}$ in New Zealand male white rabbits. Each rabbit was primed with $500 \mu \mathrm{g} P-450 \mathrm{E}$ in complete Freund's adjuvant (Difco) and boosted 4 and 6 weeks later with $40 \mu \mathrm{g}$ in incomplete adjuvant. Rabbits were then bled from the ear at weekly intervals. The serum was collected and IgG was precipitated twice with $40 \%$ ammonium sulfate. The precipitate was redissolved in PBS, extensively dialyzed and clarified, and chromatographed on a Whatman DEAE-52 column (15). Void volume fractions with a high $A_{280}$ were concentrated and stored at $-70^{\circ} \mathrm{C}$. Ouchterlony double diffusion on agar plates was carried out using the modifications of Thomas et al. (16).

Monoclonal antibodies against scup cytochrome $P$ $450 \mathrm{E}$ were obtained by conventional hybridoma techniques. Their preparation and initial characterization have been described (10). Antibodies obtained in serum-free culture fluids and ascites fluids were stored in liquid $\mathrm{N}_{2}$ or at $-70^{\circ} \mathrm{C}$ until use.

Immunoblot analysis. Immunoblotting, as originally described by Towbin et al. (17), was carried out essentially by the method of Burnette (18). However, HRP-labeled antibodies were used and dilutions and incubation times were empirically optimized. Microsomes and protein fractions were separated on $10 \%$ SDS-PAGE gels (19) and transferred overnight onto $0.45-\mu \mathrm{m}$ nitrocellulose sheets (Schleicher \& Schuell) at $4^{\circ} \mathrm{C}$ (Bio-Rad Transblot). Incubations were carried out in the presence of $5 \%(\mathrm{w} / \mathrm{v})$ dry milk for nonspecific blocking. The primary antibody was diluted in PBS/ milk and incubated with the nitrocellulose for $2 \mathrm{~h}$. The secondary antibody, either HRP-conjugated goat anti-mouse or goat anti-rabbit IgG (Bio-Rad), was then incubated with the sheets for $1 \mathrm{~h}$ followed by HRP color developer containing 4-chloro-1-naphthol (Bio-Rad) and $\mathrm{H}_{2} \mathrm{O}_{2}$ (Fisher). In some incubations we employed a secondary antibody that was not HRP conjugated (goat anti-rabbit IgG, Pharmacia), and a third incubation with rabbit peroxidase-antiperoxidase complex (Pharmacia) was carried out before color development. Development was stopped within $30 \mathrm{~min}$ by thorough rinsing with distilled water. Sheets were scanned with a Helena Labs Quick Scan R \& D densitometer (courtesy of S. Watson, Associates of Cape Cod). Some nitrocellulose sheets were stained for protein with amido black.

\section{RESULTS}

\section{Isozyme Specificity}

The specificity of antibodies to $P-450 \mathrm{E}$ in immunoblots was tested with purified or

partially purified scup $P$-450 fractions A through E. Isozymes in fractions $\mathrm{A}, \mathrm{B}$, and $\mathrm{E}$ have been described $(3,4)$ and are electrophoretically separable and structurally distinct proteins. Although not purified to homogeneity, fractions $\mathrm{C}$ and $\mathrm{D}$ contain $P$ 450 s with optical properties distinct from each other and from A, B, and E. Monoclonal antibody 1-12-3 was highly specific for $P-450 \mathrm{E}$ and did not visibly react with any protein in fractions A-D (Fig. 1A). Recognition of $P-450 \mathrm{E}$ but not other scup liver $P-450$ s was also seen with polyclonal anti- $P-450 \mathrm{E}$ (Fig. 1B). Staining of gels with Coomassie blue after transfer showed little or no remaining protein, indicating that lack of reactivity with other fractions was not due to poor transfer to the nitrocellulose. In addition, amido black staining of the nitrocellulose consistently indicated substantially complete protein transfer in the relevant regions of the gel.
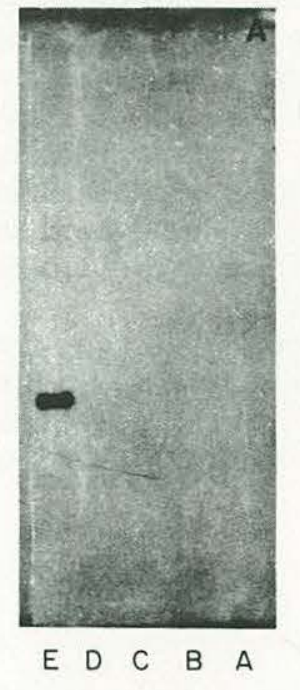

MAb 1-12-3

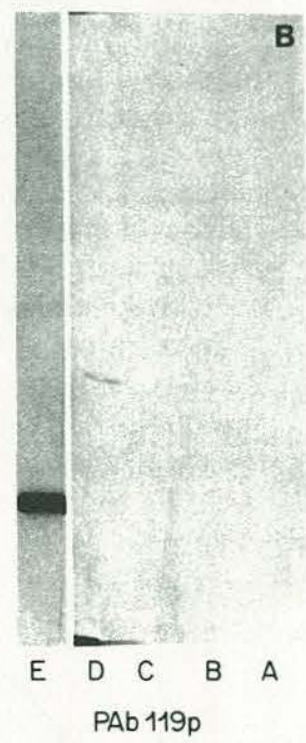

Fig. 1. Immunoblot of MAb 1-12-3 and PAb 119p with scup $P-450$ 's. (A) Fractions A, B, C, D, and E (40 pmol each) were applied to SDS gels, transferred to nitrocellulose, and incubated with MAb 1-12-3 (1:440) followed by HRP-conjugated goat anti-mouse IgG (1: 200). Staining was with HRP color developer in $\mathrm{MeOH}$ plus PBS, with $\mathrm{H}_{2} \mathrm{O}_{2}$ added immediately before use. (B) Fractions A through E, 40 pmol each. Incubations were PAb 119p (1:500), goat anti-rabbit IgG (1:200), and rabbit peroxidase anti-peroxidase (1:1000). 


\section{ANTIBODIES TO $P$-450E OF THE MARINE FISH SCUP}

Titrating a range of purified $P-450 \mathrm{E}$ amounts against MAb 1-12-3 provided quantitative results with the immunoblotting procedure. The results in Fig. 2 show a linear region up to $8 \mathrm{pmol} P-450 \mathrm{E}$ and "saturation" at higher concentrations. Repeated titrations have resulted in a linear response up to 5.0 to $8.0 \mathrm{pmol} P-450 \mathrm{E}$.

\section{$P-450 E$ in Microsomes}

Analysis of whole microsomes prepared from BNF-treated scup liver further demonstrated antibody specificity and showed xenobiotic induction of $P-450 \mathrm{E}$. Hepatic microsomes from BNF-induced scup exhibited only one band, $M_{\mathrm{r}}$ near 54,000 , upon incubation with MAb 1-12-3 (Fig. 3). The intensity of this band in BNF liver microsomes reacted with MAb 1-12-3 increased with the amount of microsomal protein applied. However, control scup microsomal $P-450$ show'ed no visible staining even when the amounts applied were twice the highest amount of BNF-scup microsomal P-450 analyzed. Six other monoclonal antibodies generated against scup $P-450 \mathrm{E}$, those designated MAb 1-8-4, 1-8-6, 1-9-5, 1-33-3, 149-5, and 1-54-8 (10), showed the same specificity. Each reacted with purified $P$ $450 \mathrm{E}$ and with only a single band, comigrating with $P-450 \mathrm{E}$, in $\mathrm{BNF}$-induced scup liver microsomes (Fig. 4).

Treatment of scup with other known $\mathrm{PAH}$-type inducers gave results similar to those with BNF (Table I). One HCB treatment regime resulted in a higher propor-

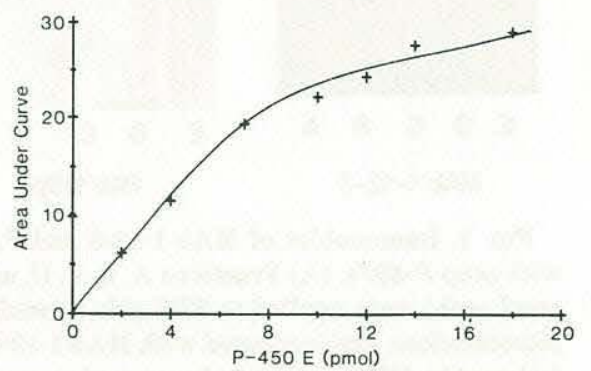

FIG. 2. Titration of purified $P-450 \mathrm{E}$ against MAb 112-3: 2 to $18 \mathrm{pmol}$ of $P-450 \mathrm{E}$ was blotted. $Y$ axis: area under the curve; $X$ axis: pmol $P-450 \mathrm{E}$ applied. Repeated scans were reproducible within 3 to $5 \%$ of the mean.

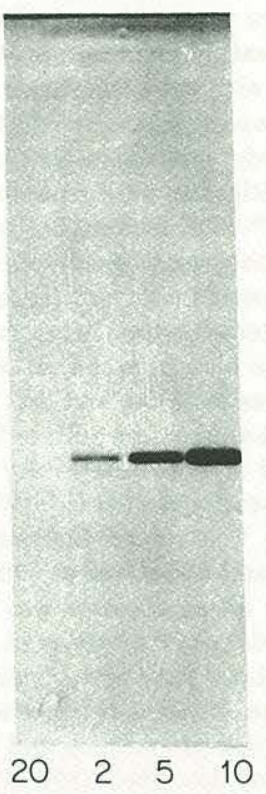

FIG. 3. Immunoblot of MAb 1-12-3 with control and BNF-treated scup microsomes. See Materials and Methods for treatment details. Control scup $P-450(20$ pmol) and 2, 5, and $10 \mathrm{pmol}$ of total $P-450$ from BNFtreated scup were applied to SDS gel. Incubation conditions were as in Fig. 1A.

tion of $P-450 \mathrm{E}$ to total $P-450$ compared to the other chemical exposures, but all treatments (BNF, $\mathrm{HCB}$, and $\mathrm{PCB}$ ) resulted in significant increases in the content of $P$ $450 \mathrm{E}$ over that in control animals. This increase in proportion of immunochemically detectable $P-450 \mathrm{E}$ accompanied a typical induction of the EROD turnover number (nmol product/min/nmol total $P-450$ ) in these fish (data not shown).

\section{Cross-Reactivity among Teleosts}

Proteins from other fish species were used to examine cross-reactivity of the MAb 1-12-3 and PAb probes. Hepatic microsomes to MC-treated rainbow trout and BNF-treated brook trout reacted with $\mathrm{MAb}$ 1-12-3 exhibited a single strong band $\left(M_{\mathrm{r}}\right.$ of about 57,000 ), but the same amounts of microsomal $P-450$ from control microsomes showed little or no staining (Fig. 5A) of this band. Polyclonal anti- $P-450 \mathrm{E}$ showed a similar strong recognition of this band in BNF-treated trout. However, the 
KLOEPPER-SAMS ET AL.

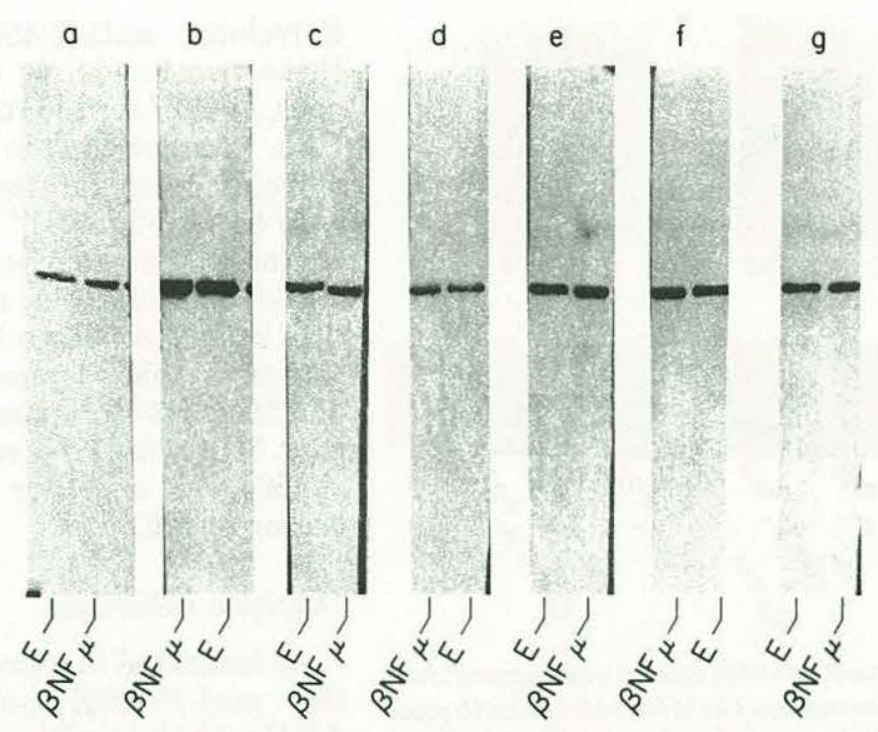

FIG. 4. Immunoblot of various monoclonal antibodies against scup $P-450 \mathrm{E}$ with purified scup $P$ 450E and BNF-treated scup microsomes. MAbs: (a) 1-54-8, (b) 1-49-5, (c) 1-33-3, (d) 1-9-5, (e) 1-8-6, (f) 1-8-4, (g) 1-12-3. For MAbs 1-8-4 and 1-12-3, 8 pmol P-450E or 20 pmol BNF-treated scup microsomes was used. All other lanes contained $10 \mathrm{pmol} P-450 \mathrm{E}$ or $30 \mathrm{pmol}$ microsomal $P-450$. MAbs were $20 \mu \mathrm{g} / \mathrm{ml}$ serum-free culture fluid, with other conditions as in Fig. 1A.

PAb also detected several faint, higher molecular weight bands that appeared with similar intensity in both control and treated trout (Fig. 5B).

Immunoblotting of killifish ( $F$. heteroclitus) microsomes gave results similar to those with trout; MAb 1-12-3 strongly recognized a single band $\left(M_{\mathrm{r}}\right.$ of about 54,000$)$ in BNF-treated fish. When microsomes containing equal amounts of spectrally determined $P$ - 450 from BNF and control fish were blotted, only a faint band was visible in control microsomes (Fig. 5C). For BNFtreated winter flounder ( $P$. americanus) as well, only a single band ( $M_{\mathrm{r}}$ of about 55,000$)$ appeared on blots probed with MAb 1-123 (data not shown). As with the other species, greater amounts of the immunochem-

TABLE I

Quantitation of Immunoblot of Cytochrome $P-450$ E and SCuP Liver Microsomes with Mab 1-12-3

\begin{tabular}{|c|c|c|c|c|}
\hline Sample & $\begin{array}{c}\text { pmol } P \text {-450 } \\
\text { applied }\end{array}$ & Area $^{a}$ & $\begin{array}{c}\text { pmol } P-450 \mathrm{E} \\
\text { calculated }\end{array}$ & $\begin{array}{l}P-450 \mathrm{E} \text { as } \% \\
\text { total } P-450^{b}\end{array}$ \\
\hline$P-450 \mathrm{E}$ & 1.5 & 125 & & \\
\hline$P-450 \mathrm{E}$ & 2.5 & 381 & & \\
\hline$P-450 \mathrm{E}$ & 4.0 & 505 & & \\
\hline PCB-treated microsomes ${ }^{c}$ & 5.0 & 280 & 2.3 & 46 \\
\hline HCB-treated microsomes ${ }^{c}$ & 5.0 & 556 & 4.2 & 83 \\
\hline BNF-treated microsomes ${ }^{c}$ & 7.0 & 375 & 2.9 & 42 \\
\hline
\end{tabular}

${ }^{a}$ The relative area under the curve of densitometric scans. Bands were scanned in the reflectance mode.

${ }^{b}$ Spectrally determined $P-450$; see Materials and Methods.

${ }^{\circ}$ Treatments were as described under Materials and Methods. The BNF sample was from pooled microsomes; the others were from individual fish. 


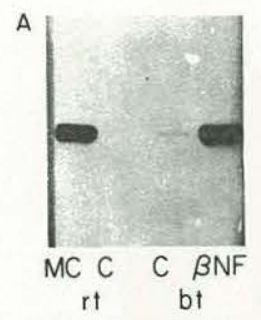

B

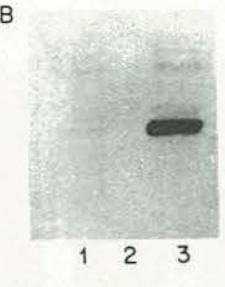

C

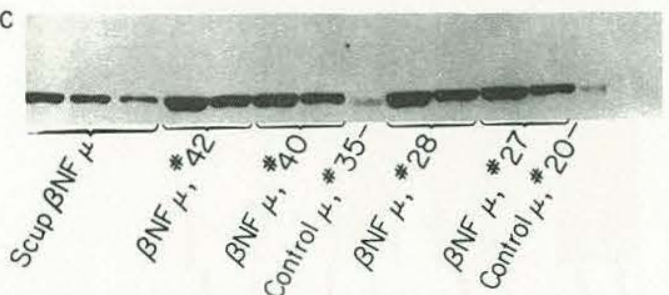

FIG. 5. Immunoblots with control and induced trout and killifish microsomes. (A) MAb 1-12-3 with 15 pmol total $P-450$ per lane, analyzed as in Fig. 1A. From left: MC-treated rainbow trout, control rainbow trout, control brook trout, BNF-treated brook trout. (B) PAb 118 with 20 pmol total $P-450$ per lane, analyzed as in Fig. 1B. Lane 1, control brook trout; lane 2, blank; lane 3, BNF-treated brook trout. (C) MAb 1-12-3 with individual killifish microsomes. $P-450(15,10$, and 5 pmol) from BNF scup microsomes was applied in the first three lanes. 20 and $10 \mathrm{pmol}$ were used from each BNF-treated sample, and 20 pmol was from control microsomes. Numbers 20, 27, and 28 were sacrificed on Day 3; all others were on Day 7.

ically determined protein in killifish and winter flounder corresponded to higher microsomal EROD turnover numbers.

\section{Cross Reactivity with Mammals}

In earlier studies, MAb 1-12-3 recognized purified rat $P-450 \mathrm{c}$ in RIA (10). Consistent with this, MAb 1-12-3 strongly recognized purified rat $P-450 \mathrm{c}$ in an immunoblot (Fig. 6A). Two of the other six monoclonal antibodies recognizing $P-450 \mathrm{E}$ in immunoblots also recognized a single band, presumably $P-450 \mathrm{c}$, in microsomes of BNF-induced rats (Fig. 6B). Surprisingly, MAb 1$12-3$, which recognized only a single band in BNF-induced scup liver microsomes (Fig. 3), recognized two bands in BNFtreated rat liver microsomes (Fig. 6C), one band corresponding to $P-450 \mathrm{c}$ and a fainter band of lower apparent molecular weight.
Polyclonal anti- $P-450 \mathrm{E}$ also recognized these two bands, or exactly comigrating ones, in BNF rat microsomes. However, the $\mathrm{PAb}$ recognized the lower band more strongly, with fainter staining of the $P$ $450 \mathrm{c}$ band (Fig. 6D). ${ }^{4}$ The lower band migrated at the same position as the MC- or isosafrole-inducible rat $P$-450d (ISF-G, (9)). This was shown by side-by-side blotting of rat microsomes with $\mathrm{PAb}$ to $P-450 \mathrm{E}$ and MAb 1-7-1 prepared against rat $P-450 \mathrm{c}$ (Fig. 6D). MAb 1-7-1 recognizes $P-450 \mathrm{c}$ and $P-450$ d, but no other proteins, in rat microsomes (20).

\section{Catalytic Inhibition}

As indicated in a preliminary report (5), the anti- $P-450 \mathrm{E}$ polyclonals inhibited AHHactivity inmicrosomesandin reconstitutions of $P-450 \mathrm{E}$. EROD activity in scup liver was also inhibited by more than $90 \%$ by these polyclonals, while ECOD activity was inhibited by only $60 \%$ (Table II). Aminopyrine $\mathrm{N}$-demethylase activity was not affected by the polyclonal antibodies (Table II).

Previous work has also shown that several of the MAbs to P-450E inhibit AHH and ECOD activity in microsomes and reconstitutions of $P-450 \mathrm{E}$ to varying degrees (10). The data in Table III show that EROD activity in rainbow and brook trout liver microsomes is inhibited by MAb 1-12-3 to the same extent as is the activity in scup liver. The microsomes in each case are those which have abundant protein recognized by MAb 1-12-3 in immunoblots.

\section{P-450E in Untreated Fish}

The above studies showed a strong and specific recognition of $P-450 \mathrm{E}$ induced by PAH-type inducers. Immunoblots of individual untreated scup caught in different areas around Woods Hole revealed a large range in $P-450 \mathrm{E}$ as a percentage of total hepatic microsomal $P$-450. Individuals collected from a site off of Nantucket Island

\footnotetext{
${ }^{4}$ In preliminary immunoblot studies, this polyclonal recognized purified $P-450 \mathrm{c}$ and the comigrating band in rat microsomes.
} 
KLOEPPER-SAMS ET AL.

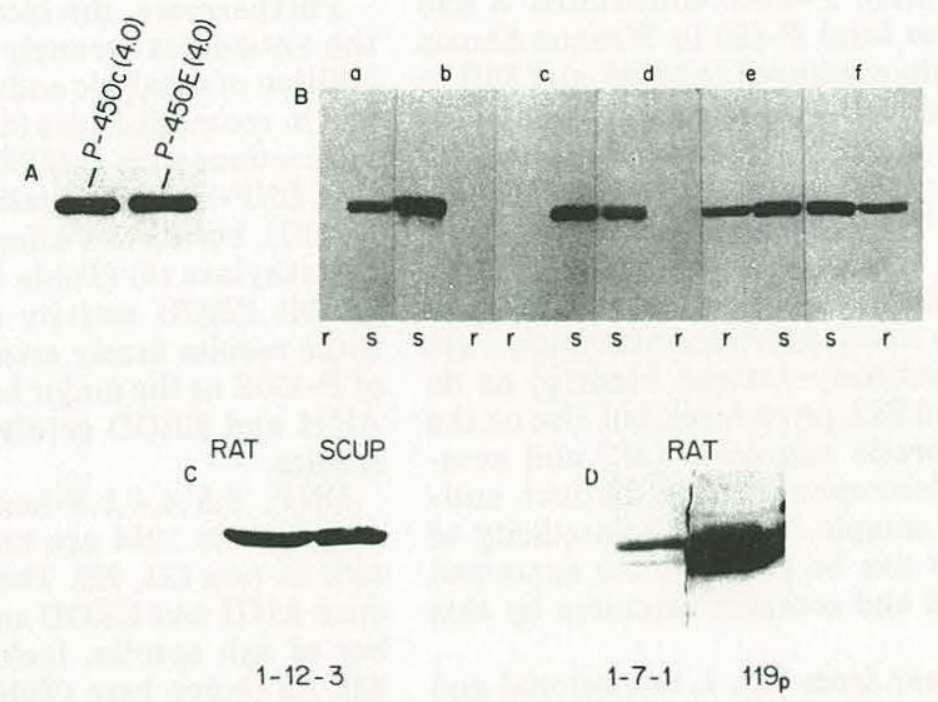

FIg. 6. Antibodies to $P-450 \mathrm{E}$ incubated against rat or scup liver microsomes. (A) MAb 1-12-3 with 4.0 pmol each of purified rat $P-450 \mathrm{c}$ and scup $P-450 \mathrm{E}$. (B) Culture fluids as in Fig. 4. MAbs: (a) $1-54-8$, (b) 1-49-5, (c) 1-33-3, (d) 1-9-5, (e) 1-8-6, (f) 1-8-4. $\mathrm{r}=150$ to $175 \mu \mathrm{g}$ BNF rat microsomes; $\mathrm{s}$ $=$ BNF scup microsomes (30-50 pmol P-450). (C) MAb 1-12-3 against $175 \mu \mathrm{g}$ BNF-treated rat microsomes and 15 pmol BNF-treated scup microsomes. Incubations as in Fig. 1A. (D) MAb 1-7-1 against $200 \mu \mathrm{g}$ BNF-treated rat microsomes, and PAb 119p against $175 \mu \mathrm{g}$ BNF-treated rat microsomes.

(Wasque Shoals) exhibited much weaker staining compared to those collected at two sites in Buzzards Bay (Cleveland Ledge and

\section{TABLE II}

INHIBITION OF BNF-TREATED SCUP HEPATIC Microsomal Activity by Polyclonal Anti- $P-450 \mathrm{E}$

\begin{tabular}{lccr}
\hline & & \multicolumn{2}{c}{ Assay conditions } \\
\cline { 3 - 4 } Enzyme & $\begin{array}{l}\mathrm{IgG} / P-450 \\
\text { activity }\end{array}$ & $\begin{array}{c}\text { Native }^{a} \\
(\%)\end{array}$ & $\begin{array}{c}\text { +PAb 119p } \\
(\%)\end{array}$ \\
\hline AHH & 30 & $100 \pm 10.7$ & $8.8 \pm 0.3^{b}$ \\
EROD & 40 & $100 \pm 11.5$ & $7.8 \pm 0.5$ \\
ECOD & 40 & $100 \pm 5.2$ & $40.3 \pm 2.1$ \\
ApND $^{c}$ & 35 & $100 \pm 1.5$ & $105.6 \pm 0.1$ \\
\hline
\end{tabular}

${ }^{a}$ Native values were, in $\mathrm{nmol}$ product $/ \mathrm{min} / \mathrm{nmol} P$ 450, $2.72(\mathrm{AHH}), 1.30$ (ECOD), and 6.42 (EROD), and $7.09 \mu \mathrm{mol}$ product $/ \mathrm{min} / \mathrm{nmol}$ (ApND). Preincubation with BSA or with preimmune IgG gave values within $10 \%$ of the native value, except for ApND, which was stimulated by preimmune IgG.

${ }^{b}$ Percentage of activity relative to native values. The results shown are for ratios of IgG to $P-450$ taken from titration curves.

${ }^{c} \mathrm{ApND}=$ aminopyrine $\mathrm{N}$-demethylase.
TABLE III

INHIBITION OF EROD ACTIVITY IN HEPATIC Microsomes of Scup and Trout Species BY MAb 1-12-3

\begin{tabular}{ccc}
\hline & \multicolumn{2}{c}{ Assay conditions } \\
\cline { 2 - 3 } $\begin{array}{c}\text { Microsome } \\
\text { source }^{a}\end{array}$ & $\begin{array}{c}\text { NBS } \\
(\%)\end{array}$ & $\begin{array}{c}\text { MAb 1-12-3 } \\
(\%)\end{array}$ \\
\hline $\begin{array}{c}\text { BNF-treated scup } \\
\text { BNF-treated } \\
\text { brook trout }\end{array}$ & $100 \pm 8.1^{b}$ & $1.5 \pm 0.4^{\circ}$ \\
$\begin{array}{c}\text { MC-treated } \\
\text { rainbow trout }\end{array}$ & $100 \pm 6.4$ & n.d. $^{d}$ \\
\hline
\end{tabular}

${ }^{a}$ Microsomes were from the scup and trout preparations used in Fig. 5.

${ }^{b} \mathrm{NBS}=$ nonspecific monoclonal antibody. EROD values in the presence of NBS are 4.54 (scup), 2.21 (brook trout), and 1.92 (rainbow trout) $\mathrm{nmol} / \mathrm{min} /$ nmol $P$-450. Activity determined with $100 \mathrm{mg}$ ascites fluid containing NBS or $\mathrm{MAb} / \mathrm{nmol} P-450$ for scup and brook trout, and $70 \mathrm{mg}$ ascites/nmol $P-450$ for rainbow trout.

${ }^{\circ}$ Percentage of activity relative to assay with NBS.

${ }^{d}$ Not detectable. Practical limit of detection is 0.0038 $\mathrm{nmol} / \mathrm{min} / \mathrm{nmol}$, or $<0.17 \%$. 
Butler Flats). $P-450 \mathrm{E}$ constituted 3 and $11 \%$ of the total $P-450$ in Wasque Shoals individuals, compared to 62,43 , and $53 \%$ in individuals collected in Buzzards Bay (Table IV).

\section{DISCUSSION}

Immunoblotting (Western blotting) is a technique which provides information not only on antibody-antigen binding, as do ELISA and RIA procedures, but also on the electrophoretic migration $\left(M_{\mathrm{r}}\right)$ and numbers of electrophoretically distinct antigens in a sample. Thus, the specificity of antibodies can be productively examined in purified and complex mixtures by this method.

As is clear from Fig. 1, monoclonal and polyclonal antibodies to scup $P-450 \mathrm{E}$ recognize a single scup hepatic $P-450$, the 54kDa immunogen $P-450 \mathrm{E}$. No other purified or partially purified $P-450$ isozyme is recognized by these antibodies. In addition, of the seven monoclonal antibodies to $P-450 \mathrm{E}$ tested, all failed to recognize any other proteins in scup microsomes (Figs. 3 and 4). This specific reaction with the $54-\mathrm{kDa}$ protein indicates that scup microsomes contain no cross-reacting proteins excluded during purification and thus lacking in analyses of purified isozymes or resolved fractions.

\section{TABLE IV}

QUANTITATION OF IMMUNOBLOT OF INDIVIdUAL FERAL SCUP MICROSOMES WITH MAb 1-12-3

\begin{tabular}{lcrc}
\hline Sample & $\begin{array}{c}\text { pmol } P-450 \\
\text { applied }\end{array}$ & Area $^{a}$ & $\begin{array}{c}P-450 \mathrm{E} \text { as \% } \\
\text { total } P-450^{b}\end{array}$ \\
\hline P-450E & 3.0 & 836 & \\
CL No. $2^{c}$ & 10.0 & 1749 & 62 \\
CL No. 6 & 10.0 & 1224 & 43 \\
BF No. $16^{c}$ & 10.0 & 1504 & 53 \\
${\text { WS No. } 4^{c}}_{\text {WS No. } 7}^{10.0}$ & 55 & 3 \\
\hline
\end{tabular}

${ }^{a}$ The relative area under the curve of the densitometric scan.

${ }^{b} P-450$ spectrally determined.

${ }^{c}$ Individual fish from CL, Cleveland Ledge; BF, Butler Flat; WS, Wasque Shoals.
Furthermore, the blotting specificity of the antibodies strongly suggests that inhibition of catalytic activity in microsomes and in reconstitutions $(5,10)$ is due to their interactions with $P-450 \mathrm{E}$. The PAbs inhibit two BNF-inducible activities $\mathrm{AHH}$ and EROD), but do not affect aminopyrine $\mathrm{N}$ demethylase (5) (Table II), and the MAbs inhibit EROD activity (Table III). Thus, these results firmly establish the identity of $P-450 \mathrm{E}$ as the major hepatic microsomal $\mathrm{AHH}$ and EROD catalyst in this marine species.

BNF, $3,3^{\prime}, 4,4^{\prime}, 5,5^{\prime}$-hexachlorobiphenyl, and Aroclor 1254 are known to induce $P$ $450 \mathrm{c}$ in rats $(21,22)$. These compounds induce AHH and EROD activities in a number of fish species, including scup $(2,11$, 23). As shown here (Table I), these chemicals also selectively induce the same protein, $P-450 \mathrm{E}$, in scup hepatic microsomes. Together with the earlier evidence indicating parallels between properties of purified $P-450 \mathrm{E}$ and properties appearing in microsomes after PAH treatment of scup $(4,7)$, these results confirm that $P-450 \mathrm{E}$ is the major PAH- or PCB-inducible isozyme in this species.

The strong specific recognition by monoclonal and polyclonal antibodies (Fig. 5) of a single protein band induced by $\mathrm{MC}$ or $\mathrm{BNF}$ in two trout species indicates the presence of a $P-450 \mathrm{E}$ counterpart in these salmonids. In rainbow trout, the increased levels of a single band in MC-treated microsomes compared to control levels, the molecular weight of this protein, and inhibition of EROD activity in MC-treated trout microsomes by MAb 1-12-3 (Table III) all indicate that this protein is identical to the BNF-inducible $P-450 \mathrm{LM}_{4 \mathrm{~b}}$ characterized by Williams and Buhler (24). The conclusion that $P-450 \mathrm{LM}_{4 \mathrm{~b}}$ is the rainbow trout counterpart to scup $P-450 \mathrm{E}$ is corroborated by cross-reactivity of $\mathrm{PAb}$ to trout $P-450 \mathrm{LM}_{4}$ with scup $P-450 \mathrm{E} .^{5}$

As in trout, the single band recognized by MAb 1-12-3 in hepatic microsomes from the other teleost species tested here, killifish and winter flounder, corresponded

\footnotetext{
${ }^{5}$ D. E. Williams, A. V. Klotz, D. R. Buhler, and J. J. Stegeman, unpublished observations.
} 
with BNF induction and high levels of EROD activity. Based on these similarities and the specificity of the antibody for scup and trout $P-450 \mathrm{~s}$, we conclude that the protein recognized by MAb 1-12-3 is the $P$ $450 \mathrm{E}$ counterpart in these animals as well. Given the phylogenetic distance between the families represented by these fish species (25), we predict that MAb 1-12-3, and perhaps the other monoclonals which bind to scup $P-450 \mathrm{E}$ in immunoblots, will specifically recognize the $P-450 \mathrm{E}$ counterpart in species from other families of fish.

Recognition of rat $P-450 \mathrm{c}$ by MAb 1-123 in immunoblots (Fig. 6A) is consistent with earlier RIA and immunoblot results (10). The specificity of MAb 1-12-3 for rat $P-450 \mathrm{c}$ has been further indicated by lack of recognition of purified $P-450 \mathrm{~b}$ or $P-450$ PCN-E (26) in solid phase RIA (10) and of purified forms designated PB-1, PB-2a (or PCN-E), 2b, 2c, 2d, 3, PB-4, PB-5, or 6 in an ELISA assay (David Waxman, unpublished data). ${ }^{6}$ In all these analyses, recognition of $P-450$ c (BNF-B) served as a positive control.

Although there is strong recognition of rat $P-450$ c by MAb $1-12-3$, not all the anti$P-450$ E monoclonals examined stained the rat protein. Of the six additional MAbs to scup $P-450 \mathrm{E}$, only two also recognize $P-450 \mathrm{c}$ (Fig. 6B). Reciprocal immunoblots using monoclonals generated against rat $P-450 \mathrm{c}$ have also indicated structural differences between the rat and fish proteins. MAbs $\mathrm{C} 4$ and $\mathrm{C} 6$, which were generated against rat $P-450 \mathrm{c}$ and do not cross-react with rat $P-450 \mathrm{~d}$ (27), recognized scup $P-450 \mathrm{E}$ in ELISA and immunoblot analyses (3). However, six other MAbs to rat $P-450 \mathrm{c}$ did not recognize scup $P-450 \mathrm{E}$ in that study. Furthermore, MAb $1-7-1$ to rat $P-450 \mathrm{c}$, which recognizes counterparts to $P-450 \mathrm{c}$ in several mammalian species $(28,29)$, did not recognize scup $P-450 \mathrm{E}$ in RIA, in immunoblots, or by enzyme inhibition (10). In addition, the $\mathrm{NH}_{2}$-terminal amino acid sequence of $P-450 \mathrm{E}$ shows no homology with rat $P-450 \mathrm{c}$ or any other known mammalian

\footnotetext{
${ }^{6}$ Some of these isozymes have equivalents in the Ryan et al. nomenclature. $2 \mathrm{c}=P-450 \mathrm{~h}, 2 \mathrm{~d}=P-450 \mathrm{i}$, $3=P-450 \mathrm{a}, \mathrm{PB}-4=P-450 \mathrm{~b}$, and PB-5 $=P-450 \mathrm{e}(9)$.
}

forms (4). These findings indicate structural homology of the PAH-inducible isozymes in these evolutionarily diverse species, expressed as at least one and possibly more highly conserved epitopes, but also demonstrate that there is a substantial degree of structural difference. Because each monoclonal binds a single characteristic epitope, the collection of antibodies to $P$ $450 \mathrm{E}$ may be useful for detailed probing of the structural relationships between and among species.

The possible recognition of $P-450 \mathrm{~d}$ by anti-scup $P-450 \mathrm{E}$ antibodies, as seen by reaction with a band in BNF-treated rat microsomes that comigrates with $P-450 \mathrm{~d}$, is intriguing. Defining the relationship between rat $P-450$ 's $\mathrm{c}$ and $\mathrm{d}$ and scup $P-450 \mathrm{E}$ may shed further light on the evolution of the $P-450$ 's. Based on intron/exon patterns, cDNA sequence homologies, and chromosome positions, Gonzalez et al. proposed earlier that genes for mouse isozymes $P_{1}$ 450 and $P_{3}-450$ (counterparts of the rat forms $P-450 \mathrm{c}$ and $P-450 \mathrm{~d}(30)$, respectively) diverged from a single ancestral gene (31) at a time subsequent to the appearance of fish in phylogeny. If so, then a more "ancestral" gene product, e.g., $P-450 \mathrm{E}$, could be related to both. More recently, gene conversion has been forwarded as a mechanism which created a large segment of sequence homology between the two genes (32), suggesting that the genes diverged much earlier. Anti-scup $P-450 \mathrm{E}$ polyclonals presumably bind to a variety of epitopes on the fish protein. These epitopes may include some common to both rat $P-450 \mathrm{c}$ and $P-450$ d, which could lie in the area of greatest homology. Stronger reactivity of polyclonal anti- $P-450 \mathrm{E}$ antibodies with rat $P-450$ d than with rat $P-450 \mathrm{c}$, as suggested by Fig. 6 , indicates that further characterization of the epitopes should provide clearer answers to these relationships. In any case, $P-450 \mathrm{E}$ could be orthologous to both $P-450 \mathrm{c}$ and $P-450 \mathrm{~d}$.

The immunoblots of untreated fish sampled directly from the environment explicitly show the presence of PAH- and PCBinducible $P-450 \mathrm{E}$. In earlier studies $(4,7)$, we noted high levels of AHH and EROD activity and other characteristics in feral 
scup. The correlation between the EROD turnover number and the immunoblot-determined percentage of total $P-450$ present as $P-450 \mathrm{E}$ in these fish was 0.98 , and both aspects correlate well with the sediment and water conditions at the three local sites. The New Bedford Harbor (Butler Flats) and the Cleveland Ledge sites are known to be contaminated with PCBs and PAH-containing petroleum (33, 34), whereas the Wasque Shoals site is nearly 30 miles distant from these sites and believed to be uncontaminated.

The close relationship between $\mathrm{PAH}-$ inducible $P-450 \mathrm{~s}$ in fish species, evidenced by recognition of the putative $P-450 \mathrm{LM}_{4 \mathrm{~b}}$ in $\mathrm{MC}$-induced rainbow trout and of a single protein in other PAH-induced fish, suggests that the antibody probes should be useful in studies of biochemical responses of various teleosts to environmental contamination. These antibodies, in fact, have been used successfully in analyses of fish from the deep sea (35). The use of immunoblotting has distinct advantages over enzymatic analysis to detect such effects, in part because it can be applied to denatured samples, an important consideration when field samples must be obtained and processed.

In summary, the results presented here establish immunochemical techniques for unambiguous identification of scup $P-450 \mathrm{E}$, and demonstrate that this protein is the $\mathrm{PAH}$-inducible, AHH-metabolizing scup $P$-450 form. These probes will be sensitive tools in analysis of the regulation and function of the major inducible $\mathrm{AHH}$ catalyst in scup and other aquatic species. Further investigations into the relationships between these proteins in fish and other vertebrates should enhance our knowledge of the evolution of this important family of proteins.

\section{ACKNOWLEDGMENTS}

We acknowledge Bruce R. Woodin and Dr. Alan V. Klotz for assistance in enzyme analysis and $P-450 \mathrm{E}$ purification. We also thank Dr. David Waxman for ELISA analysis and Dr. Frank Gonzalez for suggestions on the manuscript. This research was supported by NSF Grant OCE83-10505, by the WHOI/MIT Joint
Program, and by a WHOI Independent Study Award. This is contribution No. 6305 of the Woods Hole Oceanographic Institution.

\section{REFERENCES}

1. Nebert, D. W., AND Jensen, N. M. (1979) CRC Crit. Rev. Biochem. 6, 401.

2. Stegeman, J. J. (1981) in Polycyclic Aromatic Hydrocarbons and Cancer (Gelboin, H. V., and Ts'o, P. O., Eds.), Vol. 3, p. 1, Academic Press, New York.

3. Klotz, A. V., Stegeman, J. J., Woodin, B. R., SNOWBerger, E. A., Thomas, P. E., AND WaLSh, C. (1986) Arch. Biochem. Biophys., 249, 326.

4. Klotz, A. V., Stegeman, J. J., And Walsh, C. (1983) Arch. Biochem. Biophys. 226, 578.

5. Stegeman, J. J., Woodin, B. R., Park, S. S., Kloepper-Sams, P. J., and Gelboin, H. V. (1985) Marine Envirom. Res. 17, 83.

6. Stegeman, J. J., And James, M. O. (1985) Marine Environ. Res. 17, 122.

7. Stegeman, J. J., Klotz, A. V., Woodin, B. R., AND PAJOR, A. M. (1981) Aquatic Toxicol. 1, 197.

8. Ryan, D. E., Thomas, P. E., Korzeniowski, D., AND Levin, W. (1979) J. Biol. Chem. 254, 1365.

9. Waxman, D. J., Dannan, G. A., AND Guengerich, F. P. (1985) Biochemistry 24, 4409.

10. PARK, S. S., Miller, H., Klotz, A. V., KloepperSams, P. J., Stegeman, J. J., AND Gelboin, H. V. (1986) Arch. Biochem. Biophys., 249, 339.

11. Stegeman, J. J., Harris, E., Mayernik, J., Woodin, B. R., Giam, C. S., AND KloEpPERSAMS, P. J. Manuscript in preparation.

12. Stegeman, J. J., Binder, R. L., ANd OrRen, A. (1979) Biochem. Pharmacol. 28, 3431.

13. Lowry, O. H., Rosebrough, N. J., Farr, A. L., and Randall, R. J. (1951) J. Biol. Chem. 193, 265.

14. Klotz, A. V., Stegeman, J. J., And Walsh, C. (1984) Anal. Biochem. 140, 138.

15. Hurn, B. A. L., and Chauter, S. M. (1980) in Methods in Enzymology (Van Vunakis, H., and Langone, J. J., Eds.), Vol. 70, p. 104, Academic Press, New York.

16. Thomas, P. E., LU, A. Y. H., RYAN, D., West, S. B., KAWALEK, J., AND LEvin, W. (1976) J. Biol. Chem. 251, 1385.

17. Towbin, H., Staehelin, T., AND Gordon, J. (1979) Proc. Natl. Acad. Sci. USA 76, 4350.

18. Burnette, W. N. (1981) Anal. Biochem. 112, 195.

19. Laemmli, U. K. (1970) Nature (London) 227, 680.

20. Cheng, K.-C., Gelboin, H. V., Song, B.-J., PARK, S. S., ANd Friedman, F. K. (1984) J. Biol. Chem. $259,12279$.

21. Guengerich, F. P., Dannan G. A., Wright, S. T., MARTIN, M. V. AND KAMINSKY, L. S. (1982) Biochemistry 21, 6019 . 
22. Poland, A., And Glover, E. (1977) Mol Pharmacol. 13, 924.

23. LeCh, J. J., Vodicnik, M. J., AND Elcombe, C. R. (1982) in Aquatic Toxicology (Weber, L. J., Ed.), p. 107, Raven Press, New York.

24. Williams, D. E., ANd Buhler, D. R. (1984) Biochem. Pharmacol. 33, 3743.

25. Moyle, P. B., ANd Cech, J. J., JR. (1982) Fishes: An Introduction to Ichthyology, pp. 175-324, Prentice-Hall, Englewood Cliffs, NJ.

26. Elshourbagy, N., and Guzflian, P. (1980) J. Biol. Chem. 225, 1279.

27. Thomas, P. E., Reik, L. M., RYAN, D. E., AND LEvin, W.(1984) J. Biol. Chem. 259, 3890.

28. Fujino, T., West, D., Park, S. S., and Gelboin, H. V. (1984) J. Biol Chem. 259, 9044.

29. Friedman, F. K., Robinson, R. C., Song, B.-J.,
Crespi, C. L., Marletta, M. A., AND Gelboin, H. V. (1985) Mol. Pharmacol. 27, 652.

30. BLACK, S. D., AND COON, M. J. (1986) in Cytochrome P-450: Structure, Mechanism, and Biochemistry (Ortiz de Montellano, P. R., Ed.), p. 161, Plenum, New York.

31. Gonzalez, F. J., Mackenzie, P. I., Kimura, S., AND Nebert, D. W. (1984) Gene 29, 281.

32. Adesnik, M., AND Atchison, M. (1986) CRC Crit. Rev. Biochem. 19, 247.

33. Weaver, G. (1984) Environ. Sci. Technol. 18, 22 A.

34. TrIPP, B. W. (1985) Woods Hole Oceanographic Institute Technical Report, WHOI-85-27, CRC85-1, Woods Hole Oceanographic Institute, Woods Hole, MA.

35. Stegeman, J. J., Kloepper-Sams, P. J., And FarRINGTON, J. W. (1986) Science 231, 1287. 


\section{AFTERWORD}

Since this manuscript was written, the immunoblotting technique described herein has become a routine procedure in our laboratory. We generally employ the highly specific MAb 1-12-3. We have now screened at least 20 species of fish by this technique, and find a single band in every species. This immunoreactive protein has a $\mathrm{M}_{\mathrm{r}}$ near that of P-450E (sometimes slightly lower, sometimes higher), and is inducible by BNF, MC, 3,4,3',4' tetrachlorobiphenyl (TCB, Gooch et al., submitted), and environmental contaminants (Stegeman et al., 85; Elskus and Stegeman, submitted; B.R. Woodin, J.J. Stegeman and P.J. Kloepper-Sams, unpublished observations). In addition, MAb 1-12-3 recognition of a Norway flounder P-450E orthologue correponds to a pollution gradient and to EROD activity (Stegeman et al., 88). MAb 1-12-3 also recognizes a microsomal protein in other nonmammalian species (pigeons, sea birds, chicken; Stegeman and Woodin, unpublished observations) and at least one other mammal (the Minke whale; Goksøyr et al., 88).

The identity of the second band visible in induced rat liver microsomes has not been pursued further. Given the possibility that gene duplication may play a role in the origin and relationship of the related P-450c and P-450d isozymes in rat (P450IA1 and P450IA2, respectively; Athison and Adesnik, 86), this finding should be investigated in the future. Nebert and co-workers have concluded that rainbow trout contain a single $\mathrm{PAH}$-inducible $\mathrm{P}-450$ gene, and designate it P450IA1 (Heilmann et al., 88). A closer examination of specific portions of this (and other future) teleost sequence(s) may provide additional clues as to the evolution of the P-450IA subfamily. 
In conclusion, these antibodies have been shown to be highly specific, in immunoblots and catalytic inhibition assays, for scup microsomal P-450E and its orthologues in other teleosts. They will serve as exquisitely sensitive probes in studies of the regulation of induction of P-450E as described in the next chapters. 
CHAPTER 3:

REGULATION OF P-450E IN FUNDULUS HETEROCLITUS I:

P-450E PROTEIN AND EROD ACTIVITY AND INITIAL RNA WORK

$\begin{array}{ll} & \text { Page } \\ \text { INTRODUCTION } & 72 \\ \text { MATERIALS AND METHODS } & 75 \\ \text { Chemicals and General Procedures } & 75 \\ \text { Animals } & 75 \\ \text { Microsomal Preparation and Protein Studies } & 76 \\ \text { RNA Isolation } & 77 \\ \text { In vitro Translation of RNA and Immunoprecipitation } & 79 \\ \text { Statistics } & 81 \\ \text { RESULTS } & 81 \\ \text { Induction of P-450E Enzyme Activity } & 81 \\ \text { Induction of P-450E Protein Levels } & 86 \\ \text { RNA Isolation } & 89 \\ \text { RNA in vitro translations and immunoprecipitation } & 91\end{array}$




\section{INTRODUCTION}

The commonly accepted paradigm for TCDD- and PAH-type induction of mammalian P-450s may not be functional in fish. As outlined in Chapter 1, binding of the $A h$ receptor to the xenobiotic ligand (Poland et al., 76) is of paramount importance in the mammalian model. Interaction of the receptor-ligand complex with specific DNA sequences leads to increased transcription of some P-450 genes (Gonzalez et al., 84; Jones et al., 85). Subsequent translation of the elevated mRNA pool increases the amounts of the catalysts, thus increasing metabolism by these isozymes. Several laboratories have induced $\mathrm{AHH}$ and AHH-type activities in teleosts (e.g., Melancon et al., 81; Förlin, 80), yet attempts to identify an $A h$ receptor in fish have been unsuccessful (Denison et al., 85; Dr. J.W. Hamilton, Dartmouth College, NH, personal communication) until recently (Heilmann et al., 88). Denison and coworkers (85) have suggested that the relatively long time required for induction of P-450 activity in fish ruled out a receptor-mediated mechanism.

Heilmann et al. (88) utilized a technique to identify a TCDD-binding moiety that had failed to produce specific binding above background levels in earlier studies (Denison et al., 85; J. Hamilton, personal communication). Cytosol from untreated rainbow trout livers contained a saturable, specific TCDDbinding peak, which could be displaced with 100-fold excess MC or TCDD. The authors estimated the content of this " $A h$ receptor" to be 7.5 fmol per milligram cytosolic protein, similar to the content they had previously measured in some strains of $A h$-responsive mice. They also noted a peculiar enhancement of the TCDD-binding peak in the presence of phenobarbital, an enhancement they misreferenced as having occurred in other mammalian studies. Confirmation of this TCDD-binding peak in trout and other teleost species in future studies and 
experiments to determine its biochemical and mechanistic similarities to and differences from the mammalian $A h$ receptor will be crucial to understanding the role this moiety may play in the regulation of nonmammalian P-450 expression.

Regardless of the properties of this fish "Ah receptor," it is important to examine PAH induction in fish to determine the mechanisms involved in PAHmediated P-450 induction and to evaluate the evolution of these regulatory mechanisms. In the next two chapters, I address questions of transcriptional enhancement as a possible mechanism for MC-type induction of P-450 in fish. Chapter 3 addresses the temporal pattern of P-450E protein induction in Fundulus heteroclitus, including increases in catalytic activity, and Chapter 4 addresses $\mathrm{P}-450 \mathrm{E}$ mRNA induction and its temporal relationship to protein induction.

I initially planned to carry out this work with scup as the experimental animal, due to the wealth of background material we had concerning the MFO system in scup (Klotz et al., 83 and 86), and because the antibody probes had been generated against the scup $\mathrm{P}-450 \mathrm{E}$ protein (Chapter 2). The scup available at the outset of my studies, however, exhibited a wide range of EROD activities, indicating that some of these animals retained some induced P-450s. (This supposition has been substantiated by the fact that healthy scup held for 1 or more years in flowing, well-aerated Nantucket Sound water at the Environmental Systems Laboratory exhibit consistently low hepatic microsomal EROD activities and P-450E protein levels.) Thus, I switched to the estuarine killifish or mummichog Fundulus heteroclitus, another well-studied fish whose P-450 system is known to be inducible by PAHs (Stegeman, 79; Binder et al., 85; Elskus and Stegeman, 89). These non-migratory animals are relatively easy to obtain from local, "clean" sites most of the year and thus generally exhibit low constitutive EROD activities. Preliminary studies indicated that the MAb and PAb antibodies 
generated against scup P-450E would readily cross-react with the Fundulus orthologue (e.g., Chapter 2, Figure 5). In addition, Fundulus survive well (usually) in laboratory settings with minimal flow, and are able to withstand wide ranges of temperature and salinity (Griffith, 74). These last points are more significant for the turnover studies described in Chapter 5 (recirculating water system used) and for future studies of temperature effects on the induction response. Low temperatures can retard the induction response in teleosts, possibly producing temporal segregration of regulatory processes (e.g., mRNA and protein turnover) which are closely linked in more rapidly responding systems. Thus, aspects of basic physiology such as poikilothermy can be exploited to examine facets of induction that may be difficult to distinguish in mammals.

This chapter examines induction of the P-450E orthologue in Fundulus heteroclitus at the protein level, focusing on EROD as an indicator of P-450E enzymatic activity and on measurement of $\mathrm{P}-450 \mathrm{E}$ protein by immunoblotting as described in Chapter 2. B-naphthoflavone (BNF) was used throughout these studies as a non-carcinogenic model MC-type inducer. BNF binds well to the $A h$ receptor site (Okey et al., 80; Blank et al., 87) and induces the same isozymes and activities as $\mathrm{MC}$ and other aromatic hydrocarbons in mammals. The goals were to establish that $\mathrm{P}-450 \mathrm{E}$ protein and catalytic activity could be induced in Fundulus, to generate a time course of both the increase and the decrease in protein and enzyme activity following a single dosage of the compound, and to see how well protein levels and enzyme activities correlate. Finally, material from these experiments would be used to determine whether BNF treatment can induce an increase in P-450E mRNA concentration. 


\section{MATERIALS AND METHODS}

\section{Chemicals and General Procedures}

Chemicals were obtained from Sigma (general chemicals), BioRad (electrophoretic materials, ion exchange beads), Fisher Scientific (general solvents), Burdick and Jackson (high-purity solvents), and other companies as noted below. Gel electrophoresis apparatus was obtained from BioRad or Hoefer Scientific. Bicinchoninic acid (BCA) was obtained from Pierce. A Shimadzu UV 260 spectrophotometer was used for kinetic assays, spectral analysis and OD readings. L-[4,5-3 $\mathrm{H}$-leucine (150 Curies/mmol) was obtained from Amersham. Scintillation cocktail was Scintiverse II from Fisher Scientific.

Animals

Sexually immature female Fundulus heteroclitus were obtained by seining or cast netting at two local sites: Scorton's Creek, Sandwich and Little Sippewissett Marsh, Falmouth. Scup (Stenotomus chrysops) were caught by angling in local Woods Hole waters in the late summer months, and rainbow trout (Salmo gairdneri) were obtained from the Sandwich Hatchery, Sandwich, MA, with the cooperation of Lloyd Raymond. Scup were maintained at $20^{\circ} \mathrm{C}$ and fed alternately with locally-caught squid and Trout chow (Purina). Fundulus were maintained in flowing, filtered $13-16^{\circ} \mathrm{C}$ seawater on a diet of ground Trout Chow or Tetramin Flakes (Tetrawerke GmbH, West Germany). Reproductive status is known to affect MFO activity in fish (Stegeman and Chevion, 80) including Fundulus (McKee et al., 83). Gonadosomatic (GSI, gonad weight/total body weight $x$ 100) and hepatosomatic (HSI, liver weight/total body weight $\mathrm{x} 100$ ) indices provide a measure of this status. Thus, GSI and HSI were monitored in this group for several weeks prior to treatment to assure consistency in these values. 
Fundulus were given a single intraperitoneal (i.p.) injection of corn oil (controls) or $50 \mathrm{mg} / \mathrm{kg} \mathrm{BNF}$ (Aldrich) in corn oil at time 0 , fed regularly and sacrificed at the times noted in the Results section. Scup (150 to $300 \mathrm{~g}$ ) and rainbow trout (100 to $200 \mathrm{~g}$ ) received $40 \mathrm{mg} / \mathrm{kg}$ of $\mathrm{BNF}$ or an equivalent volume of corn oil alone.

Microsomal Preparation and Protein Studies

Hepatic microsomes were prepared from fresh liver pieces or from liver pulverized in liquid nitrogen. Portions of the pulverized liver powders were also taken for RNA isolation (see below). Microsomes were prepared by established methods (Stegeman et al., 81), as outlined in Chapter 2. Some microsomes were prepared by a minor modification of this method: the final centrifugation step was for 70 minutes at $38,200 \mathrm{rpm}$ in a $70.1 \mathrm{Ti}$ rotor, Beckman L8-60M Ultracentrifuge. Preliminary results using scup microsomes indicated no difference in microsomal P-450 specific content or EROD activity when fresh livers and liquid nitrogen frozen, pulverized liver powders were compared (B.R. Woodin and P.J. Kloepper-Sams, unpublished observations). EROD activity (Klotz et al., 84), spectral cytochrome b5 and spectral P-450 content were measured as before (Stegeman et al., 81). Protein concentration was determined either by the established method of Lowry et al. (51) or by the newer bicinchoninic acid (BCA) assay (Smith et al., 85). Both protein determinations employed bovine serum albumin (BSA) to develop daily standard curves in microassays of up to 25 ug protein.

Immunoblots were used to determine $\mathrm{P}-450 \mathrm{E}$ protein content. The primary antibody was anti-scup P-450E MAb 1-12-3 (described in Chapter 2). In all cases, the secondary antibody was Bio-Rad's affinity-purified, horseradish peroxidase-linked, goat anti-mouse immunoglobulin G (IgG). Purified scup 
P-450E served as standard, and only signals from unknowns falling within the linear portion of the standard curves ( 3 or 4 concentrations of scup P-450E per gel) were quantified. Microsomal proteins from control and early time point BNFtreated Fundulus were separated on large $(16 \times 18 \mathrm{~cm}) 6$ to $13 \%$ gradient gels to improve clarity of immunoreactive bands; bands from most BNF-treated animals could be easily detected on either large or "mini" gradient gels.

\section{RNA Isolation}

In all steps involving RNA work, from preparation of buffers to RNA isolation itself to use of RNA in translation mixtures or Northern blots, precautions were taken to avoid RNase contamination or activity. Immediately upon fish dissection, livers were weighed and pieces were pulverized under liquid nitrogen using a ceramic mortar and pestle. RNA was isolated through a cesium chloride $(\mathrm{CsCl})$ cushion by a modification of the procedure briefly outlined by Chirgwin et al. (79) for tissue containing high nuclease activity.

I chose this method based on earlier results with purification of rainbow trout, scup, winter flounder and Fundulus genomic DNA. We found that although good yields could be obtained from trout tissue by normal methods, high molecular weight DNA was rapidly lost from marine teleost tissues during routine incubations (E. Metz and P.J. Kloepper-Sams, unpublished observations). This indicated that nuclease activity could be a problem during RNA preparation as well. Thus, the more time-consuming but rigorous method of lysis in guanidine thiocyanate (GTC) buffer and centrifugation through a cesium chloride cushion was chosen. If multiple samples were prepared, individual tissues were ground under liquid nitrogen and stored in liquid nitrogen until needed. All solutions were prepared with diethyl pyrocarbonate- (DEPC, Sigma) treated water, then autoclaved or filtered ( 0.45 or 0.22 micron syringe filters, Nalgene) for sterility. 
Sterile plasticware was obtained from American Scientific Products (now Baxter Health Care). GTC solutions were made fresh for each set of experiments and stored in brown glass bottles at $4^{\circ} \mathrm{C}$ until use. All glassware was washed, rinsed, dried, and baked at approximately $230^{\circ} \mathrm{C}$ for 4 hours. Gloves were worn throughout the procedure and care was taken to avoid contamination of the samples with nucleases during all nucleic acid work.

For each sample, about 7.0 $\mathrm{ml} \mathrm{GTC} \mathrm{(GTC:} 4 \mathrm{M}$ guanidine thiocyanate (Fluka Chemie A.G.)/ $25 \mathrm{mM}$ sodium citrate, $\mathrm{pH}$ 7.0/ 0.5\% sarkosyl (N-lauroyl sarcosine)/ 0.1 M B-mercaptoethanol) was added to a glass homogenization vessel at room temperature. Pulverized liver powder $(0.5$ to $1.0 \mathrm{~g})$ was quickly added to the vessel and passed 2-3 times at maximum speed $(1160 \mathrm{rpm})$ to remove any clumps and homogenize well. This viscous, yellow/brown mixture was transferred to a sterile $50 \mathrm{ml}$ capped centrifuge tube. The homogenization vessel and pestle were rinsed twice with $0.5 \mathrm{ml} \mathrm{GTC}$, which was added to the tube. Solid CsCl (Special Biochemical Grade, Gallard-Schlesinger Chemical Mfg. Corp.) was added at $0.4 \mathrm{~g}$ per $\mathrm{ml}$ homogenate and the tube inverted slowly by hand to completely dissolve the $\mathrm{CsCl}$. The dense lysate was carefully layered over $3.5 \mathrm{ml} \mathrm{CsCl} \mathrm{Cushion} \mathrm{(6.2} \mathrm{M} \mathrm{CsCl/} 100 \mathrm{mM}$ EDTA, pH 7.0) in a labeled ultracentrifuge tube (Beckman Ultra-Clear, $14 \times 89 \mathrm{~mm}$ ). Tubes were centrifuged at $30,000 \mathrm{rpm}, 20^{\circ} \mathrm{C}$ for 18 hours in a SW $41 \mathrm{Ti}$ rotor head in a Beckman L8-60M ultracentrifuge.

Using sterile techniques, the supernate was removed until about $1 \mathrm{ml}$ of liquid remained. The tube was cut about $1 \mathrm{~cm}$ above the pellet and discarded. The sides of the remaining tube were rinsed three times with $0.5 \mathrm{ml} \mathrm{GTC}$. GTC rinses were carefully removed and the pellet was rinsed three times or more with ice-cold $70 \% \mathrm{EtOH}$ to remove any remaining GTC. After air drying, the pellet was slowly 
dissolved in a small volume of TE (10 mM Tris, $\mathrm{pH} 8.0 / 1 \mathrm{mM}$ EDTA) and transferred to a sterile $1.8 \mathrm{ml}$ Eppendorf tube. Sodium acetate $(0.1$ volume of $3 \mathrm{M}$ solution, $\mathrm{pH} 5.2)$ and ice-cold $75 \% \mathrm{EtOH}$ (2.2 volumes) were added and the mixture was left on ice or at $-20^{\circ}$ for several hours or overnight to precipitate the RNA.

The pellet was spun down in a cold $\left(4^{\circ} \mathrm{C}\right)$ microcentrifuge (eppendorf $5415)$ at $10,000 \mathrm{rpm}(12,000 \mathrm{~g})$ for 10 minutes. The supernate was drained off and the dried pellet resuspended in $2 \mathrm{ml} 80 \% \mathrm{EtOH}$, spun again, the rinse repeated, and the pellet dried thoroughly. The pellet was then dissolved in a smaller volume of TE. Small aliquots of the RNA were diluted in TE or water for spectrophotometric readings to determine concentration. Finally, 2.5 volumes of $75 \% \mathrm{EtOH}$ were added and the RNA was stored at $-20^{\circ} \mathrm{C}$. To reprecipitate the RNA for subsequent manipulations, 0.1 volume of $3 \mathrm{M}$ sodium acetate ( $\mathrm{pH}$ 5.2) was added to a small volume of the RNA/EtOH mixture and left overnight at $-20^{\circ} \mathrm{C}$. The pellet was spun down the following day and resuspended in a minimal volume of TE or water.

In vitro Translation and Immunoprecipitation

In vitro translation was accomplished according to the manufacturer's directions with rabbit reticulocyte lysate (BRL), $5 \mathrm{uCi} \mathrm{L-}\left[4,5-{ }^{3} \mathrm{H}\right]$ leucine and 10 ug total RNA per incubation. Translation of globin mRNA served as a positive control. Small aliquots of translation products were spotted on $2.4 \mathrm{~cm} \mathrm{GF/C}$ filters (Whatman), precipitated with cold $10 \%$ trichloroacetic acid (TCA), rinsed with 5\% TCA and diethyl ether (Mallinckrodt), dried and counted in a Beckman LS 1801 scintillation counter. A quench curve was established with Liquid Scintillation Tritium Quenched Standards (\# 566683, Beckman) and the "H\#" technique (Beckman operating manual). Triplicate determinations of the $\mathrm{H} \#$ were 
made for each vial and used to convert cpm to dpm for each unknown. Counting efficiency was generally around $47 \%$ for TCA-precipitated translation products. Unknowns were counted at least in duplicate.

Remaining translation products were precipitated essentially according to Fagan et al. (83) with non-immune IgG (Biomedical Technologies, Cambridge, $\mathrm{MA}$ ) and anti-P-450E polyclonal antibodies (PAb) in the presence of immunoprecipitin. Immunoprecipitin (BRL), a suspension of formalin-fixed Staphylococcus aureus cells, was first treated according to manufacturer's instructions to reduce protein sloughing and resultant high backgrounds, then resuspended to $10 \%(\mathrm{v} / \mathrm{v})$ in immunoprecipitation buffer (1\% Triton X-100/ $1 \%$ sodium desoxycholate (Difco)/ 0.1\% SDS/ 0.5\% Trasylol (Aprotinin)/ $50 \mathrm{mM}$ Tris, $\mathrm{pH} 7.5 / 150 \mathrm{mM} \mathrm{NaCl})$. Immunoprecipitation buffer $(0.5 \mathrm{ml})$ was added to the in vitro translation mixture, followed by 20 ug non-immune IgG. The mixture was vortexed and incubated on ice for 30 minutes. Immunoprecipitin (100 to 110 ul) was added and the incubation left on ice for 30 minutes more. The pellet was spun down for 3 minutes at $9000 \mathrm{rpm}$ in a cold microcentrifuge.

The supernate was transferred to a fresh tube and the pellet saved as the "pre-immune" pellet. Purified scup P-450E (0.05 ug) was added to the supernate as a carrier, followed by 20 ug anti-P-450E PAb. The mixture was incubated on ice for 30 minutes, 100 to $110 \mathrm{ul}$ immunoprecipitin was added and the mixture was incubated an additional 30 minutes. The pellet was spun down as before and all pellets ("pre-immune" and "P-450E-specific") were washed as follows: twice with immunoprecipitation buffer $+0.5 \mathrm{M} \mathrm{KCl}$, once with immunoprecipitation buffer alone, and once with Tris/Nonidet $(10 \mathrm{mM}$ Tris $\mathrm{Cl}, \mathrm{pH} 7.5 / 0.5 \%$ Nonidet $\mathrm{P}-40)$. Pellets were resuspended in $60 \mathrm{ul} \mathrm{SDS} / \mathrm{BME}$ treatment buffer $(0.25 \mathrm{M}$ Tris, $\mathrm{pH} 6.8 / 40 \%$ glycerol/ $4 \%$ SDS/ $0.32 \%$ bromophenol blue/ $5 \%$ 
B-mercaptoethanol) and boiled for 10 minutes to elute antigen and antibody from immunoprecipitin. Tubes were spun at $6000 \mathrm{rpm}$ for 10 minutes to pellet the immunoprecipitin and the supernates were size separated by electrophoresis on large 9\% SDS-PAGE gels overnight. Gels were saturated with dimethyl sulfoxide ( $\mathrm{Me}_{2} \mathrm{SO}$, Aldrich), impregnated with $20 \%$ (w/w) 2,5 diphenyloxazole/ $\mathrm{Me}_{2} \mathrm{SO}$, rinsed thoroughly in water, dried under vacuum onto Whatman 3MM paper and exposed to Kodak X-Omat AR film at $-70^{\circ} \mathrm{C}$ (Bonner and Laskey, 74). The $\mathrm{M}_{\mathrm{r}}$ of radiolabeled bands were determined by comparison to MW standards (Sigma) included in the gels and stained with Coomassie blue.

Statistics

Statistical analyses were carried out by standard methods (Zar, 74). Single factor analysis of variance was performed with Statworks (Cricket Ware) or Statview 512+ (BrainPower). When ANOV analysis rejected the hypothesis of equal means, Student-Newman-Keuls and Dunnett's tests were employed to determine which means were significantly different.

\section{RESULTS}

Induction of P-450E Enzyme Activity

In an initial Fundulus heteroclitus induction experiment using a $50 \mathrm{mg} / \mathrm{kg}$ dose, EROD activities were highest on the last day sampled, which was the third day following exposure (data not shown). All fish survived the treatment with corn oil or BNF dissolved in corn oil, but the times chosen for sampling were too short to determine the peak of activity or establish a time course. Thus, a similar experiment was carried out for seven days. Females were chosen for this and all subsequent studies as males were generally smaller (generating less liver tissue per fish), and there were possible sex differences which could complicate evaluation 
of the results (Stegeman and Chevion, 80; McKee et al., 83). Fundulus exhibit strong secondary sexual dimorphisms (e.g., brilliant yellow abdomen in the male, differential coloration and size of stripes) during the mating season, and more subtle sexually differentiated characteristics are apparent to the experienced eye year-round. Thus, only females were treated and gonadal identity was confirmed after sacrifice.

Basic parameters of the experimental fish from the 7 day experiment are shown in Table 3-1. As before, all fish survived treatment. The hepatosomatic index (HSI), an indicator of general health and condition, was between 3 and 4, typical values for laboratory Fundulus kept on a diet of Trout chow or Tetramin. The gonadosomatic index (GSI) indicates the gonadal and thus reproductive status of the animal. Fundulus spawn in the summer months, but development of the gonads can be strongly affected by water temperature and light cycles. A spent or immature fish would typically have a GSI of below 1, while extremely "ripe" females show GSIs of 15 or more. These animals had gonads that were beginning to develop, as indicated by GSIs of 3 to 5 . Microsomal yield is an indication of both the degree of contamination of the isolated microsomal fraction with other subcellular materials and of the yield compared to the starting material. In my hands, a yield of 15 to $20 \mathrm{mg}$ protein per gram liver is typical for Fundulus. 
TABLE 3-1:

7 Day Fundulus Experiment: HSI, GSI, and Microsomal Yield

\begin{tabular}{cccc} 
time, & HSI & GSI & microsomal yield \\
dose & $(\%$ liver/body wt $)$ & $(\%$ gonad/body wt $)$ & $(\mathrm{mg}$ protein $/ \mathrm{g}$ liver $)$ \\
\hline
\end{tabular}

Day 1

$\begin{array}{llll}\text { control } & 3.49 \pm 0.82(7)^{\mathrm{a}} & 3.51 \pm 2.34 & 15.5 \pm 2.6 \\ \text { BNFb }^{\mathrm{N}} & 2.85 \pm 0.96(8) & 3.72 \pm 1.51 & 19.8 \pm 2.7\end{array}$

Day 3

$\begin{array}{llll}\text { control } & 3.98 \pm 0.89(7) & 4.68 \pm 1.96 & 15.8 \pm 3.9 \\ \text { BNF } & 3.45 \pm 2.04(9) & 5.02 \pm 2.27 & 13.2 \pm 3.9\end{array}$

Day 7

$\begin{array}{llll}\text { control } & 4.04 \pm 0.61(8) & 3.95 \pm 0.79 & 10.1 \pm 4.3 \\ \text { BNF } & 3.50 \pm 1.67(9) & 4.16 \pm 1.31 & 14.4 \pm 3.7\end{array}$

HSI = hepatosomatic index (liver weight/total body weight $\mathrm{x} 100$ )

GSI = gonadosomatic index (gonad weight/total body weight $\mathrm{x} 100)$

$\mathrm{a}(\mathrm{N})=$ number of individuals analyzed. Values given are mean $\pm \mathrm{sd}$.

bDosage: On Day 0, 29 females received a single i.p. injection of approximately $100 \mathrm{ul} \mathrm{at} 50 \mathrm{mg} / \mathrm{kg}$ BNF dissolved in corn oil. Control females $(\mathrm{N}=22)$ received the same volumes of corn oil only. Fish were maintained in tanks containing 15 liters standing seawater, with up to 13 individuals per tank, and fed ground Trout Chow every other day. Water $\left(15^{\circ} \mathrm{C}\right)$ was changed on alternate days. 
Table 3-2 shows results of microsomal assays from these animals. BNF and other MC-type inducers are not known to induce cytochrome $\mathrm{b}_{5}$, another microsomal heme-containing protein, in mammals. As expected, the specific content of cytochrome $b_{5}$ was not significantly different with time or with treatment. The specific content of spectral P-450 was increased in the BNF-treated animals on Day 3 and Day 7. This increase in "total" P-450 is often seen with MC-type inducers in mammals and fish, but is not as marked in Fundulus as in some other species, such as scup and winter flounder.

Increases in EROD activity, which is known to be catalyzed specifically by scup P-450E or its orthologue in other teleosts (Klotz et al., 83; KloepperSams et al., 87), corresponded with increases in P-450 content. Compared with controls, the mean EROD activity was elevated in BNF-treated fish by Day 1, was significantly higher by Day 3 , and increased still further by Day $7^{1}$. These trends were seen whether EROD activity was expressed on a protein basis (specific activity, nmol product formed per minute per mg microsomal protein) or a P-450 basis (turnover number, nmol product formed per minute per nmol spectral $\mathrm{P}-450)$. Thus, the EROD catalyst (P-450E) made up a greater proportion of the $\mathrm{P}-450$ population, as measured by spectral means, in the BNF-treated animals, and also a greater proportion of the microsomal protein complement in these fish. This experiment established that the $50 \mathrm{mg} / \mathrm{kg}$ dose could, without mortality or visible sublethal effects, induce the PAH-inducible P-450 isozyme in Fundulus.

This experiment also showed that the response of fish to BNF is slower than that of rodents to a similar dose of the same compound. Because EROD activity was still increasing at the last time point chosen, the peak of activity could not be established. Consequently, a longer term experiment was carried 
TABLE 3-2:

Fundulus heteroclitus Induction Experiment, Microsomal Characteristics

\begin{tabular}{|c|c|c|c|c|c|}
\hline time & dose & $\begin{array}{c}\mathrm{b}_{5}, \\
\mathrm{pmol} / \mathrm{mg}\end{array}$ & $\begin{array}{c}\mathrm{P}-450, \\
\mathrm{nmol} / \mathrm{mg}\end{array}$ & $\begin{array}{c}\text { EROD, } \\
\mathrm{nmol} / \mathrm{min} / \mathrm{mg}\end{array}$ & $\begin{array}{c}\text { EROD, } \\
\mathrm{nmol} / \mathrm{min} / \mathrm{nmol} \mathrm{P}-450\end{array}$ \\
\hline \multirow[t]{2}{*}{ Day 1} & control & $42.7 \pm 5.5(6)^{\mathrm{a}}$ & $0.171 \pm 0.049$ & $0.272 \pm 0.050$ & $1.76 \pm 0.68$ \\
\hline & BNF & $39.3 \pm 9.6(8)$ & $0.178 \pm 0.058$ & $0.468 \pm 0.148$ & $2.71 \pm 0.86$ \\
\hline \multirow[t]{2}{*}{ Day 3} & control & $29.2 \pm 14.3(7)$ & $0.101 \pm 0.057$ & $0.139 \pm 0.152$ & $1.57 \pm 1.09$ \\
\hline & BNF & $46.4 \pm 20.0(9)$ & $0.228 \pm 0.074 *$ & $0.790 \pm 0.331 * *$ & $3.48 \pm 0.84 *$ \\
\hline \multirow[t]{2}{*}{ Day 7} & control & $49.3 \pm 16.0(8)$ & $0.137 \pm 0.073$ & $0.293 \pm 0.175$ & $2.31 \pm 0.90$ \\
\hline & BNF & $70.8 \pm 12.9(9)$ & $0.283 \pm 0.045++$ & $1.58 \pm 0.40++$ & $5.63 \pm 1.24++$ \\
\hline
\end{tabular}

$\mathrm{a}(\mathrm{N})=$ number of individuals analyzed. Values given are means \pm standard deviations.

bEROD = ethoxyresorufin O-deethylase activity

$*=P<0.01 \mathrm{c}$ (control) vs BNF group of that day,

** $=P<0.001 \mathrm{c}$ vs BNF group of that day,

$++=P<0.001 \mathrm{c}$ vs BNF group of that day, and of this BNF group compared to Day $1 \mathrm{c}$, and to Day $1 \mathrm{BNF}$. 
out, following the same treatment protocol. BNF-treated and control fish were sampled at the same time of day on Days $0,1,4,7,12,16$ and 20.

Again, the specific content of cytochrome b5 did not change significantly with either time or treatment (Table 3-3). The specific content of spectrallydetermined P-450 was significantly elevated only in the Day 7 BNF-treated group. Levels of EROD activity did not change over time in the control fish, but increased dramatically in BNF-treated animals (Table 3-3). This was true whether EROD activity was expressed as specific activity (Table 3-3) or as turnover number (Figure 3-1). As before, the mean EROD activity in BNF-treated fish was higher on Day 1 than that of control fish, but EROD activity was not significantly different from Day 0 or other control groups until Day 4. The levels of activity then remained significantly elevated in the BNF-treated animals through Day 20. Specific activity in BNF-treated fish peaked by Day 7, then declined to $35 \%$ of the maximal value by Day 20 . Turnover numbers also declined to $45 \%$ of the maximal value by Day 20 .

Induction of P-450E Protein Levels

As described in detail elsewhere (Park et al., 86a; Chapter 2; KloepperSams et al., 87), monoclonal antibody (MAb) 1-12-3 recognizes only P-450E in immunoblot analysis of scup microsomal preparations. It also recognizes a single BNF-inducible protein, with a $\mathrm{M}_{\mathrm{r}}$ of about 55,000, in Fundulus hepatic microsomes (see Chapter 2, Figure 5). Immunoreactive protein content was low in control Fundulus and increased up to 19 fold in BNF-treated animals (Figure 3-1). Because the total P-450 content was elevated only on Day 7 (which may account for the slight dip in EROD turnover number [nmol/min/nmol P-450] on day 7), the content of another isozyme(s) must have declined. 
TABLE 3-3:

Fundulus heteroclitus Induction Experiment (20 day), Microsomal Characteristics

\begin{tabular}{|c|c|c|c|c|c|c|}
\hline time & $\mathrm{b}_{5}{ }^{\mathrm{a}}$ & $\mathrm{P}-450^{\mathrm{b}}$ & ERODC & $b_{5}$ & $\mathrm{P}-450$ & EROD \\
\hline & \multicolumn{3}{|c|}{ Control Animals } & \multicolumn{3}{|c|}{ BNF Animals } \\
\hline Day 1 & $80.5 \pm 16.6$ & $0.200 \pm 0.065$ & $0.220 \pm 0.105$ & $73.4 \pm 24.3$ & $0.213 \pm 0.094$ & $0.363 \pm 0.166$ \\
\hline Day 4 & $56.6 \pm 12.9$ & $0.182 \pm 0.025$ & $0.184 \pm 0.143$ & $64.8 \pm 15.7$ & $0.200 \pm 0.038$ & $1.34 \pm 0.26^{* *}$ \\
\hline Day 12 & $62.9 \pm 20.1$ & $0.173 \pm 0.075$ & $0.234 \pm 0.236$ & $64.5 \pm 9.9$ & $0.157 \pm 0.038$ & $1.01 \pm 0.39 * *$ \\
\hline Day 16 & $68.6 \pm 22.3$ & $0.176 \pm 0.055$ & $0.204 \pm 0.179$ & $75.1 \pm 24.2$ & $0.177 \pm 0.059$ & $0.910 \pm 0.365^{* *}$ \\
\hline Day 20 & nd & nd & nd & $70.2 \pm 12.1$ & $0.176 \pm 0.034$ & $0.534 \pm 0.149^{*}$ \\
\hline
\end{tabular}

Control Group Means

$66.8 \pm 18.0 \quad 0.173 \pm 0.052 \quad 0.187 \pm 0.145$

\footnotetext{
a Spectrally-determined cytochrome $\mathrm{b}_{5}, \mathrm{pmol} / \mathrm{mg}$ protein

b Spectrally-determined $\mathrm{P}-450, \mathrm{nmol} / \mathrm{mg}$ protein

c $\mathrm{EROD}=$ ethoxyresorufin o-deethylase activity, $\mathrm{nmol}$ product $/ \mathrm{min} / \mathrm{mg}$ protein

d All values are means $\pm \mathrm{sd}, \mathrm{N}=6$

e nd $=$ value not determined

Values significantly different from Day 0 control values by Dunnett's test $(\mathrm{Zar}, 74), * P<0.05, * * P<0.01$
} 
Figure 3-1
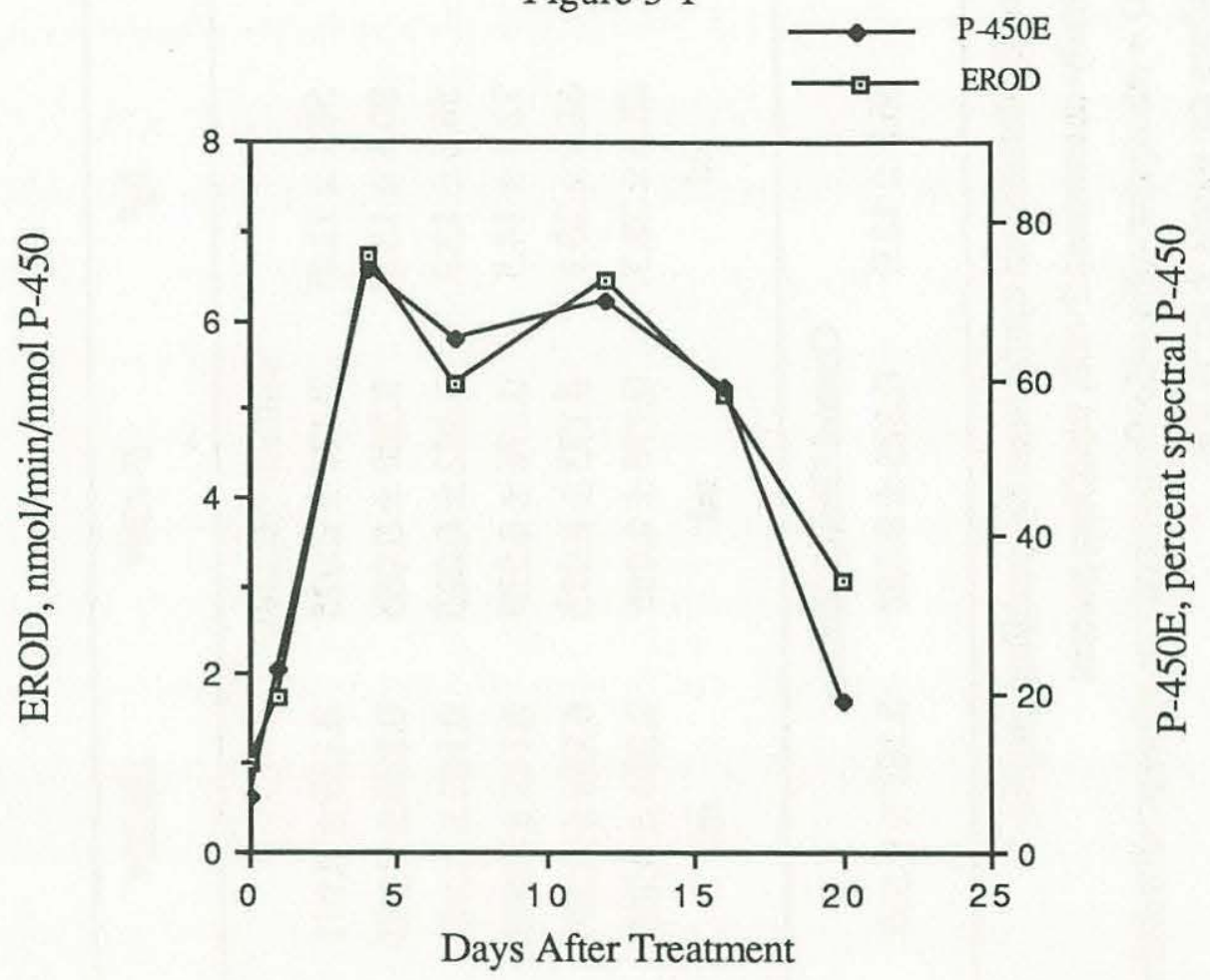

FIGURE 3-1: Temporal response of Fundulus microsomal P-450E protein and EROD activity following BNF treatment, 20 day experiment

Fundulus were given $50 \mathrm{mg} / \mathrm{kg} \mathrm{BNF}$ on day 0 and sacrificed as indicated. P-450E (closed diamonds) was quantitated immunochemically and EROD activity (open squares) was measured fluorometrically. Means from 6 animals per group are shown. Control P-450E means from Day 0 to Day 16 ranged from 4.7 to $9.7 \%$, and control EROD means ranged from 0.80 to 1.25 . 
If we assume that spectral analysis measures total microsomal P-450 content and that MAb 1-12-3 has the same affinity for the Fundulus orthologue as for the standard (scup P-450E), then P-450E comprised around 5\% of the total P-450 in control Fundulus, and rose to an average of $75 \%$ of the total P-450 in Fundulus that were highly induced by BNF (Figure 3-1). The BNF-induced rise in EROD activity corresponds directly with increases in content of the EROD catalyst itself. The same direct correspondence is observed when EROD activity per mg protein and P-450E specific content are compared (correlations $>0.9$ for EROD and P-450E protein values for individual samples, on both "per mg" and "per nmol P-450" bases). Thus, the trend in P-450E and EROD activity increases was apparent within the P-450 population (turnover number and percent P-450), as well as more generally in the microsomal preparation.

RNA Isolation

Having established the time course of EROD activity and P-450E protein induction, it was necessary to show that there are measurable differences in P-450E specific mRNA levels in uninduced and induced animals. As mentioned in the Materials and Methods section, I suspected that RNase activity would be high in the tissues of marine fishes, and so I chose a method of RNA isolation originally designed for use with pancreatic tissue (Chirgwin et al., 79). RNA was quantitated by taking spectrophotometric readings at 260 and $280 \mathrm{~nm}$ (Maniatis et al., 84). An optical density (OD) of 1.0 at $260 \mathrm{~nm}$ corresponds to $40 \mathrm{ug} / \mathrm{ml}$ single stranded RNA. The ratio OD 260/280 provides an estimate of the purity of the nucleic acid. Pure RNA should have an OD 260/280 of about 2.0. Proteins have a peak at $280 \mathrm{~nm}$ due to the contribution of aromatic amino acid residues, and protein-contaminated samples of RNA will have a 260/280 ratio lower than 2.0. Phenol contamination will also reduce this ratio. Typical teleost liver RNA yields 
and OD 260/280 readings are shown in Table 3-4. Samples from individual experiments were combined in this tabulation. The high OD 260/280 readings in all cases indicate that the RNA samples were quite pure, with little contamination by protein or phenol. RNA yield increased slightly for both Fundulus and scup preparations with time, presumably due to operator improvement in isolation technique. This range of yields is consistent with published yields from similar tissue in other species based on mammalian liver and cell culture estimates (Alberts et al., 83).

TABLE 3-4:

Teleost RNA Isolation

\begin{tabular}{|c|c|c|c|c|}
\hline Sample & date & $(\mathrm{N})$ & $\begin{array}{c}\text { OD } \\
260 / 280 \\
\end{array}$ & $\begin{array}{c}\text { yield, } \\
\text { (mg/g liver) }\end{array}$ \\
\hline $\mathrm{Fh}$ & $8 / 86$ & (2) & $2.1, \quad 2.1$ & $1.4,2.0$ \\
\hline Fh & $2 / 87$ & (3) & $2.0 \pm 0.1$ & $1.9 \pm 0.0$ \\
\hline $\mathrm{Fh}$ & $4 / 87$ & (17) & $1.9 \pm 0.5$ & $5.7 \pm 1.3$ \\
\hline Fh & $6 / 88$ & (13) & $1.9 \pm 0.1$ & $7.0 \pm 2.2$ \\
\hline scup & $7 / 87$ & (16) & $2.1 \pm 0.0$ & $4.2 \pm 1.1$ \\
\hline scup & $12 / 87$ & (5) & $2.2 \pm 0.1$ & $4.3 \pm 2.0$ \\
\hline scup & $6 / 88$ & (9) & $2.0 \pm 0.1$ & $7.4 \pm 3.8$ \\
\hline
\end{tabular}

$\mathrm{Fh}=$ Fundulus heteroclitus

$(\mathrm{N})=$ number of RNA samples prepared, generally from pulverized hepatic tissue. 
$\underline{\text { RNA in vitro translation and immunprecipitation }}$

Translation

Once RNA of high purity and good yield was obtained, it could be tested in an in vitro translation system, with the ultimate goal of quantitating P-450E mRNA. Scup and Fundulus RNA samples were translated using the micrococcal nuclease-digested rabbit reticulocyte lysate mixture provided by BRL, and the manufacturer's protocol was closely adhered to. The method was optimized for RNA concentration and magnesium ion concentration. First, various concentrations of the rabbit globin mRNA provided in the kit were translated and TCA-precipitable counts were plotted versus concentration (Figure 3-2). The relationship between counts and amount of mRNA used in the assays was linear, with a correlation coefficient of 0.996 . The concentration dependence of translation of total RNA isolated from BNF-treated scup was also examined (Figure 3-3A). Very low or very high concentrations of total RNA result in decreased incorporation of label. As Figure 3-3A indicates, 15 ug total RNA resulted in fewer dpm than did 12 or 9 ug RNA. The large deviation at 18 ug makes it difficult to intrepret the result at this higher concentration, but it seems clear that 9 ug is adequate. Thus, all subsequent translations were carried out with 10 ug total RNA. Some RNAs may require additional magnesium ions for efficient translation. Thus, scup total RNA was translated in the presence of an additional $0.5 \mathrm{mM}$ and $1.0 \mathrm{mM} \mathrm{Mg} \mathrm{Mg}^{++}$. As Figure 3-3B clearly demonstrates, added magnesium reduced the efficiency of translation. Therefore, additional magnesium ions were not routinely added to the reaction mixture. 
Figure 3-2

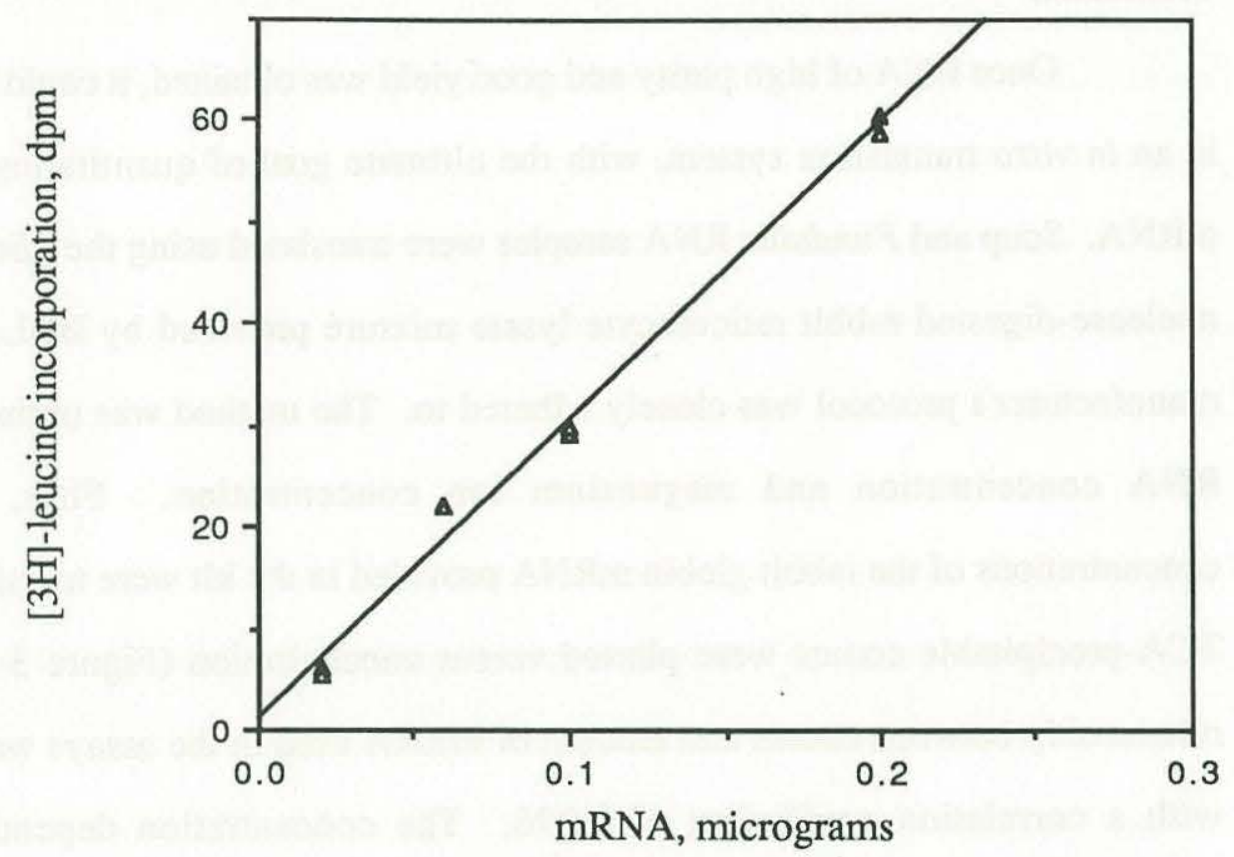

FIGURE 3-2: Effect of mRNA concentration on [ $\left.{ }^{3} \mathrm{H}\right]$-leucine incorporation Rabbit globin RNA were translated in vitro according to BRL Translation Kit instructions for 60 minutes at $30^{\circ} \mathrm{C}$ in the presence of $5 \mathrm{uCi}\left[{ }^{3} \mathrm{H}\right]$-leucine. Radioactive translation products were TCA-precipitated on GF-C filters and counted. The mean of the duplicate blank values $(12,454 \mathrm{dpm} ; 0 \mathrm{ug}$ RNA) was subtracted from all other values. Duplicate samples were counted at each concentration and plotted. The y-axis units are in dpm $x 10^{4}$. Linear regression of the line: $r^{2}=0.994$. 
Immunoprecipitation

Teleost RNA translation products were precipitated in the presence of immunoprecipitin (a suspension of $S$. aureus cell walls containing protein A) with a non-specific and a P-450E specific antibody. The utility of a polyclonal antiscup P450E (Kloepper-Sams et al., 87) antibody in immunoprecipitation was established in preliminary experiments with RNA isolated from BNF-treated scup. Lane 3 of Figure 3-4A shows that a number of tritiated products are present after translation of the total population of mRNAs, with numerous high molecular weight peptides as well as smaller peptides. Thus, little or no degradation of mRNAs encoding translation products of various sizes or of translation products themselves occurred. Non-specific IgG precipitated several peptides from this larger pool, whereas anti-P-450E precipitated only a single in vitro translation product of 54,000, identical to the known $\mathrm{M}_{\mathrm{r}}$ of purified P-450E (Klotz et al., 83;

Figure 3-4A). Although several peptides were precipitated by the non-immune antibody, no attempts were made to obtain "cleaner" control precipitates because the non-immune IgG did not precipitate any peptides at or near the Mr of P-450E.

Fundulus RNA was isolated from the livers of Day 0 (control) and Day 4 (control and BNF) animals from the 20 day BNF induction experiment. By Day 4, P-450E and EROD values were clearly elevated by BNF treatment (Table 3-3 and Figure 3-1) and P-450E mRNA levels were expected to be greater in BNFtreated than in control fish. A fluorogram of immunoprecipitated translation products from Day 0 and Day 4 Fundulus is shown in Figure 3-4B. As with scup, the non-immune IgG precipitated numerous products from each sample (lanes 1, 4 and 5). These bands occur in both control and induced Fundulus samples at the same intensity, indicating that these are non-specific, non-induced 
FIGURE 3-3: Conditions affecting the efficiency of translation of teleost RNA

3-3A: 6 to 18 ug of total RNA from BNF-treated scup was translated in vitro as described in Figure 3-2. Duplicate samples were counted for each concentration and their values plotted after subtraction of the blank (blank mean $\mathrm{dpm}=10760 \pm 1264)$. A line is drawn through the mean values of the duplicate readings. Y-axis values are $\mathrm{dpm} \times 10^{4}$.

3-3B: 15 ug of total scup RNA was translated (as described in Figure 3-2) in the presence of additional $\mathrm{Mg}^{++}$. Blank values as in Figure 3-3A. Y-axis values are dpm $\times 10^{4}$. Linear regression of the line: $r^{2}=0.953$. 
Figure 3-3
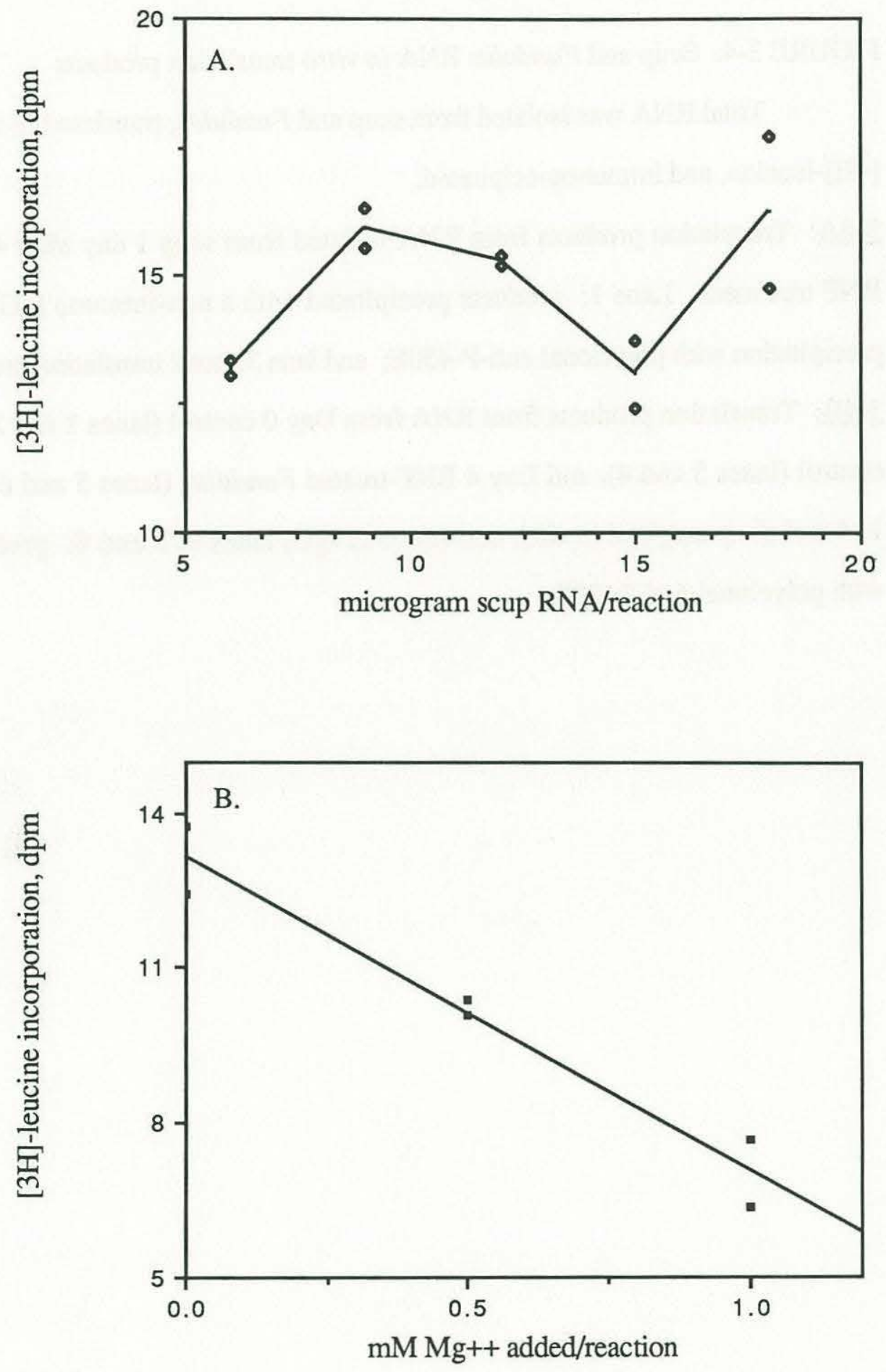
FIGURE 3-4: Scup and Fundulus RNA in vitro translation products

Total RNA was isolated from scup and Fundulus, translated in vitro with $\left[{ }^{3} \mathrm{H}\right]$-leucine, and immunoprecipitated.

3-4A: Translation products from RNA isolated from scup 1 day after $40 \mathrm{mg} / \mathrm{kg}$ BNF treatment. Lane 1: products precipitated with a non-immune IgG; lane 2: precipitation with polyclonal anti-P-450E; and lane 3: total translation products. 3-4B: Translation products from RNA from Day 0 control (lanes 1 and 2), Day 4 control (lanes 3 and 4), and Day 4 BNF-treated Fundulus (lanes 5 and 6). Lanes 1, 4 and 5: precipitation with non-immune $\mathrm{IgG}$, lanes 2, 3 and 6: precipitation with polyclonal anti-P450E. 
(Figure 3-4)
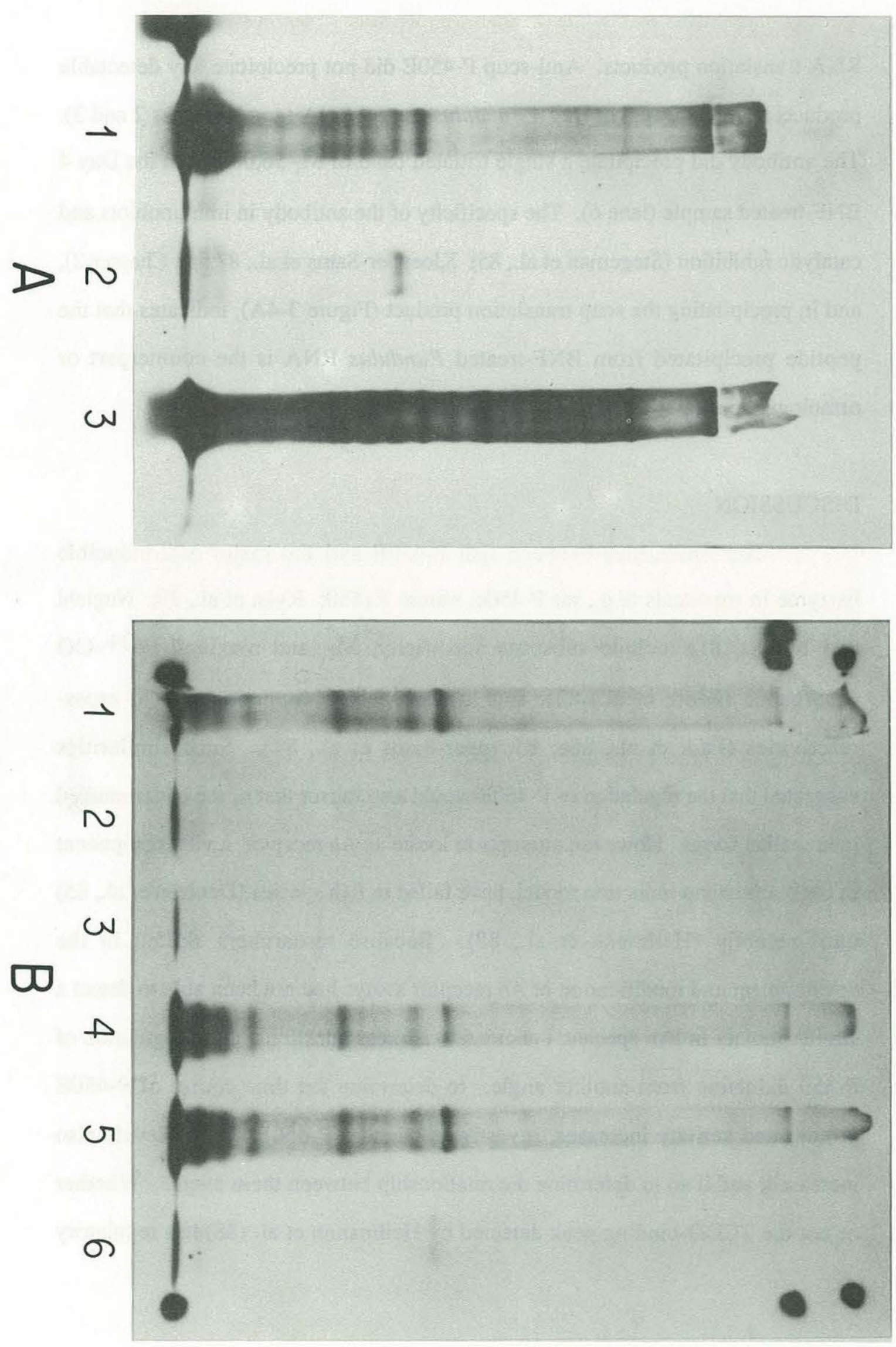
RNA translation products. Anti-scup P-450E did not precipitate any detectable products from the Day 0 or Day 4 Fundulus control RNA samples (lanes 2 and 3). The antibody did precipitate a single tritiated band of $\mathrm{M}_{\mathrm{r}} 56,000$ from the Day 4 BNF-treated sample (lane 6). The specificity of the antibody in immunoblots and catalytic inhibition (Stegeman et al., 85; Kloepper-Sams et al., 87 and Chapter 2), and in precipitating the scup translation product (Figure 3-4A), indicates that the peptide precipitated from BNF-treated Fundulus RNA is the counterpart or orthologue to scup P-450E.

\section{DISCUSSION}

The similarities between fish $\mathrm{P}-450 \mathrm{E}$ and the major MC-inducible isozyme in mammals (e.g., rat P-450c, mouse $\mathrm{P}_{1} 450$; Ryan et al., 79; Negishi and Nebert, 81) include substrate specificity, $\mathrm{M}_{\mathrm{r}}$, and maximal $\mathrm{Fe}^{2+}-\mathrm{CO}$ absorbance (Klotz et al., 83), and highly specific immunochemical crossreactivities (Park et al., 86a; Kloepper-Sams et al., 87). Such similarities suggested that the regulation of $\mathrm{P}-450 \mathrm{E}$ would also mirror that of the better-studied mammalian forms. However, attempts to locate an $A h$ receptor, a vital component in the mammalian induction model, have failed in fish species (Denison et al., 85) until recently (Heilmann et al., 88). Because researchers skilled in the development and modification of $A h$ receptor assays had not been able to detect a similar moiety in fish species, I decided to address questions of the regulation of P-450 induction from another angle: to determine the time course of P-450E protein and activity increases, investigate whether P-450E mRNA levels also increased, and if so to determine the relationship between these events. Whether or not the TCDD-binding peak detected by Heilmannn et al. (88) has regulatory 
properties similar to those of the mammalian $A h$ receptor, the question of mechanisms of induction in lower vertebrates must still be addressed.

The first step in determining the molecular mechanisms of regulation was to establish the time course of induction of P-450E activity and protein expression. After this was determined, I could examine RNA levels prior to and during initial increases in enzyme levels (see Chapter 4). Although total P-450 content did not change or increased only slightly with BNF treatment (Table 3-2 and Table 3-3), both EROD activity and immunodetectable P-450E content rose dramatically within 4 days and remained elevated for 20 days (Table 3-3 and Figure 3-1).

Although temporal profiles for induction of catalytic activities have been shown for fish, this is the first study specifically quantitating levels of an induced $\mathrm{P}-450$ isozyme over an extended time. The rise and fall of P-450E protein and EROD activity (Figure 3-1) track each other so closely that it is clear that the elevated level of the catalyst is responsible for EROD activity over the entire period. (Catalytic inhibition studies corroborate this statement: monoclonal antibody 1-12-3, which recognizes only P-450E in teleost microsomal preparations, inhibits EROD activity in all teleosts tested, including Fundulus EROD activity, while not affecting other MFO activities (Stegeman et al., 85; Kloepper-Sams et al., 87; unpublished observations).)

In other experiments, $\mathrm{PAH}$-induced $\mathrm{P}-450$ activities in fish returned to control levels after even longer periods. For example, sheepshead (Archosargus probatocephalus) held in the winter at $14^{\circ} \mathrm{C}$ retained elevated levels of $\mathrm{AHH}$ and EROD activities 4 weeks after MC treatment (James and Bend, 80). Similarly, rainbow trout treated with $100 \mathrm{mg} / \mathrm{kg}$ BNF and held at $10^{\circ} \mathrm{C}$ had maximal EROD activity at 3 days, followed by a steady decline but not a complete return to control values by 6 weeks after treatment (Andersson et al., 85). We suggest that elevated 
levels of the P-450E orthologue were responsible for the maximal and continued high activity levels in those studies as well.

Most mammalian studies have examined temporal relationships of rat or mouse PAH-inducible enzyme activity only until a peak or plateau in $\mathrm{AHH}$ or EROD activity was established, usually between 24 and 48 hours. Negishi and Nebert (81) found that B6 ( $A$ h-responsive) mice treated with $250 \mathrm{mg} / \mathrm{kg} \mathrm{MC}$ had elevated $\mathrm{AHH}$ activities by 12 hours, which reached a maximum at 48 hours and remained at this high value at 72 hours. In MC-treated rats, Fagan et al. (86) found that $\mathrm{AHH}$ was half-maximal by 14 hours, peaked at 24 hours and remained stable through 48 hours. In one of the few experiments that also examined the decline in monooxygenase activity following exposure to $\mathrm{MC}$ compounds, Boobis et al. (77) measured AHH activity in mice treated with a single injection of 80 $\mathrm{mg} / \mathrm{kg}$ BNF. AHH activity peaked at 40 hours and returned to basal levels by 72 hours. These authors reported similar results with rats.

A broad comparison between the mammalian and the fish literature indicates that comparable doses of PAH compounds produce a slower response in fish that is maintained longer. Interestingly, in the presence of Aroclor 1254 or 3,4,5,3',4',5'-hexachlorobiphenyl (HCB), rat P-450c is induced for longer periods than those listed above (Parkinson et al., 83a and 83b; Hardwick et al., 85). Slow metabolism of the inducer has been advanced as a possible cause of this persistence. TCDD, which induces mammalian AHH and EROD activity for up to 35 days after treatment (Poland and Glover, 73), is known to persist in the body for long periods. BNF and PAH are very rapidly metabolized and eliminated in fish (Stegeman et al., 84; Goddard et al., 87), arguing against slow metabolism of the inducer as a cause of persistent induction in fish. The prolonged persistence 
of the PAH-inducible catalyst may be characteristic in teleost species, particularly at low temperatures.

The next step in investigating the molecular mechanisms of P-450E regulation was to establish a method of P-450E mRNA measurement. The GTC method of RNA isolation consistently provided teleost RNA of high yield and purity (Table 3-4). In the rabbit reticulocyte system used here, an increase in translation product corresponds to elevated mRNA encoding that gene product. Given the specificity of the antibodies (Kloepper-Sams et al., 87; Chapter 2) and the results obtained with immunoprecipitation (Figure 3-4), we are confident that translation products precipitated by the anti-P-450E antibodies corresponded to peptides translated from P-450E mRNA.

The identical $\mathrm{M}_{\mathrm{r}}$ of scup and Fundulus microsomal P-450E proteins and their respective translation products are consistent with similar studies of MCinducible mammalian P-450s in which the $\mathrm{M}_{\mathrm{r}}$ of immunoprecipitated translation products are near the $\mathrm{M}_{\mathrm{r}}$ of the corresponding proteins (e.g., Bresnick et al., 81; Fagan et al., 86). The first protein found to retain a membrane-insertion signal peptide was rabbit P-450 form 2 (Black and Coon, 86). Black and Coon compared the amino-terminal amino acid residues of several P-450s and found them to be extremely hydrophobic, with the exception of some mitochondrial P-450s and the cytosolic, bacterial P-450cam. The two known teleost aminoterminal sequences are also very hydrophobic and are highly conserved (Table 3-5). The scup and trout amino-terminal sequences are more highly conserved, with a single amino acid substitution in 9 residues, than are the mammalian sequences. This is interesting from an evolutionary "unit time"/ functional restriction viewpoint, as ancestral scup and trout diverged from one another long before these closely-related mammals did. As one teleost sequence was 
TABLE 3-5:

Amino-Terminal Sequences of Selected P450IA1s

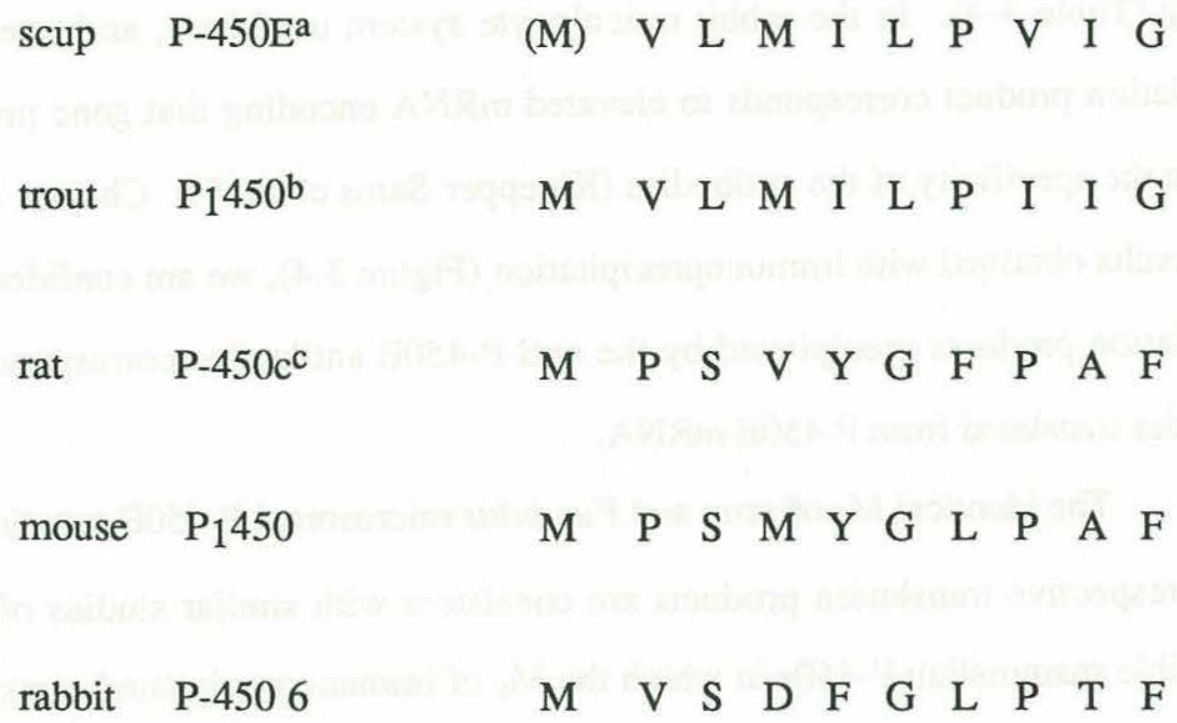

a The scup P-450E sequence was obtained by Edman degradation of the apoprotein (Klotz et al., 83). The (M) indicates that methionine was not detected by amino acid determination, but is probably present in the protein.

b The trout sequence was deduced from the nucleotide sequence. The cDNA was sequenced by Heilmann et al. (88) using the dideoxy method of Sanger et al. (77).

c The mammalian P-450 sequences were determined by Edman degradation of the purified forms. Sequences as reported by Black and Coon (86) and references therein. 
determined from purified P-450E protein (Klotz et al., 83), and the other one was deduced from the nucleotide sequence of the 5' coding region of a fish P450IA1 cDNA (and thus, derived from the P-450 mRNA sequence; Heilmann et al., 88), it is likely that neither fish protein undergoes cleavage and loss of the hydrophobic signal peptide region. Again, this is consistent with the findings from mammalian studies. Thus, a pre-P-450E protein is probably not synthesized and major posttranslational modifications of the peptide sequence are not likely to occur in these teleost species (scup, trout, and Fundulus).

In this chapter, I have established the time course of induction of P-450E protein and EROD activity in Fundulus following treatment with a single, nonlethal dosage of BNF. As expected if P-450E is the major BNF-inducible EROD catalyst, temporal increases in P-450E and EROD activity are highly correlated. I also determined conditions for isolation of total teleost RNA, translation of this RNA in an in vitro system, and precipitation of RNA translation products with non-specific and specific antibodies. Anti-P-450E precipitates a single band from scup and Fundulus translation products with the $\mathrm{M}_{\mathrm{r}}$ of the mature $\mathrm{P}-450 \mathrm{E}$ in both species. This band is present in samples prepared from RNA of BNF-treated scup and BNF-treated Fundulus, but was not detectable in RNA from control animals of either species. This result further indicates that the precipitated translation product is in fact the inducible P-450E. These studies establish the foundation for investigations of the temporal relationships between $\mathrm{P}-450 \mathrm{E}$ protein and mRNA levels, as described in the following chapter. 
1 Short term experiments are described in detail in Chapter 4. 


\section{CHAPTER 4:}

REGULATION OF P-450E IN FUNDULUS HETEROCLITUS II:

TEMPORAL PATTERNS OF P-450E PROTEIN AND mRNA INDUCTION

INTRODUCTION 106

MATERIALS AND METHODS 106

General Methods 106

$\begin{array}{ll}\text { Plasmid Isolation } & 107\end{array}$

$\operatorname{pfP}_{1} 450-3$ ' Isolation and Labeling 109

Isolation of Genomic Teleost DNA 112

Southern (Genomic) Blots $\quad 114$

Northern (RNA) Blots 115

$\begin{array}{ll}\text { RESULTS } & 116\end{array}$

Plasmid and cDNA Isolation and Characterization $\quad 116$

$\begin{array}{lr}\text { Southern Blot Analysis } & 122\end{array}$

Induction of P-450E Activity \& Protein Levels - short term study 123

Induction of P-450E mRNA Levels - short term study 127

Decline in P-450E mRNA Content $\quad 130$

$\begin{array}{ll}\text { DISCUSSION } & 133\end{array}$ 


\section{INTRODUCTION}

Chapter 3 established induction of teleost P-450E on the protein level: P-450E protein content and enzymatic activity rose concomitantly in Fundulus heteroclitus following exposure to the MC-type inducer BNF. Following in vitro translation of hepatic RNA from BNF-treated Fundulus, a single translation product was precipitated by anti-scup P-450E antibodies, and its $\mathrm{M}_{\mathrm{r}}$ agreed well with that of the authentic protein (as recognized by the P-450E-specific antibody MAb 1-12-3). This precipitable peptide was only apparent with RNA isolated from BNF-treated animals, further indicating that this mRNA corresponds to the P-450E message. In this Chapter, the temporal changes in mRNA levels are investigated and compared to changes in P-450E protein levels in the initial stages of the induction process in order to address the question of transcriptional regulation of P-450E expression in these animals. In addition, mRNA levels are examined over a longer time period to determine whether the presence of the mRNA is responsible for the maintenance of protein expression.

A specific cDNA probe of $\mathrm{P}-450 \mathrm{E}$ nucleic acid content, $\mathrm{pfP}_{1} 450-3^{\prime}$, is utilized in several of the following experiments. The isolation and characterization of this probe is described prior to the discussion of the induction experiments themselves.

\section{MATERIALS AND METHODS}

\section{General Methods}

Materials were obtained from the sources listed in Chapter 3, or from individual suppliers as noted. Animal collection and care, chemical treatment, preparation of hepatic microsomes and hepatic RNA, and statistical analyses were 
carried out as described in Chapter 3. The precautions listed in Chapter 3 for RNA isolation were adhered to for all nucleic acid work described here. For the 48 hour and 13 day BNF induction experiments, two to three Fundulus livers were pooled in order to obtain sufficient tissue for RNA isolation and microsomal preparations from identical starting tissue.

\section{Plasmid Isolation}

A recently isolated and characterized (Heilmann et al., 88) $1.4 \mathrm{~kb}$ (kilobasepair) 3'-specific trout $\mathrm{P}_{1} 450 \mathrm{cDNA}\left(\mathrm{pfP}_{1} 450-3^{\prime}\right)$ was used to probe Fundulus RNA. The cDNA was prepared by growing E. coli DH-alpha cells (courtesy of Dr. D.W. Nebert, NIH) harboring a $4 \mathrm{~kb}$ pUC19 plasmid (named "pUC19-pfP $1450-3$ ' ") containing the cDNA fragment and isolating the plasmid by cesium chloride/ethidium bromide centrifugation (Ish-Horowicz and Burke, 81). Alternately, a plasmid preparation was obtained from Dr. J.J. Lech (Medical College of Wisconsin). Growth of the E. coli and purification of the plasmid was carried out in conjunction with Darlene Bianca in Dr. Douglas Prasher's laboratory (WHOI) and is summarized below.

The $E$. coli were streaked on plates containing Luria medium supplemented with ampicillin and incubated overnight at $37^{\circ} \mathrm{C}$. Single colonies had developed by the next morning, so the plates were sealed with Parafilm and stored at $4^{\circ} \mathrm{C}$. A few days later, a single colony was picked from a plate and used to inoculate 1 liter of Luria broth plus ampicillin. The bacteria were grown overnight, shaking, at $37^{\circ} \mathrm{C}$.

Cells were spun down $\left(10\right.$ minutes, $0^{\circ} \mathrm{C}, 6000 \mathrm{rpm}$, Beckman JA10 rotor head) and the pellet was resuspended in $40 \mathrm{ml}$ of Solution I ( $50 \mathrm{mM}$ glucose/ $25 \mathrm{mM}$ Tris, $\mathrm{pH}$ 8.0/ $10 \mathrm{mM}$ EDTA). Solution II ( $80 \mathrm{ml}, 1 \% \mathrm{SDS} / 0.2 \mathrm{~N} \mathrm{NaOH}$, prepared immediately prior to use) was added, the tube swirled and left on ice 5 
minutes. Ice cold Solution III ( $40 \mathrm{ml}, 5 \mathrm{M} \mathrm{KOAc}, \mathrm{pH} 4.8)$ was added, the tube inverted to mix and left on ice 15 minutes. After addition of $10 \mathrm{ml}$ distilled water, the mixture was spun at $10,000 \mathrm{rpm}$ for 20 minutes to pellet the precipitate. The supernate was poured off through cheesecloth and its volume measured. Isopropanol ( 0.6 volumes) was added to the supernate and the tube inverted to mix. After centrifugation at $8000 \mathrm{rpm}$ for 10 minutes, the supernate was removed and the white pellet was partially dried in a Speedvac concentrator. TE $(5 \mathrm{ml}, \mathrm{pH}$ 8.0) was added to the dried pellet, which dissolved after thorough shaking. After transfer to a $12 \mathrm{ml}$ plastic tube, a small amount of $2 \mathrm{M}$ Tris base was added to neutralize the solution, and $1 \mathrm{~g}$ cesium chloride was added per ml liquid. The tube was spun at $10,000 \mathrm{rpm}$ for 5 minutes at room temperature to pellet any precipitated protein. This pellet was washed with a few $\mathrm{ml} \mathrm{TE}$ and respun. Both supernates were combined and $400 \mathrm{ul}$ ethidium bromide ( $\mathrm{EtBr}, 10 \mathrm{mg} / \mathrm{ml} \mathrm{stock}$ ) was added. The tube was spun again at $10,000 \mathrm{rpm}$ for 5 minutes to precipitate the flecks of EtBr which bound to protein and other material. The clear "day glo" orange supernate was transferred carefully to a new tube, leaving behind a deep red pellet. The density of the solution was adjusted to $1.60 \mathrm{~g} / \mathrm{ml}$, with a refractive index (R.I.) of 1.394 , by the addition of solid $\mathrm{CsCl}$. This solution was centrifuged in $12.5 \mathrm{ml}$ QuickSeal (Seton) tubes in a Ti70 rotor head, 40,000 rpm, $20^{\circ} \mathrm{C}$, for about 40 hours (Beckman L8-60M ultracentrifuge).

A wide reddish band was removed from the middle of the tube via a 18.5 gauge needle and $10 \mathrm{ml}$ syringe. After addition of a $\mathrm{CsCl} / \mathrm{TE}$ solution and $100 \mathrm{ul}$ $\mathrm{EtBr}$, the mixture was adjusted to a R.I. of 1.386 and centrifuged at $40,000 \mathrm{rpm}$ for about 24 hours. The reddish band was removed as before and the EtBr was repeatedly extracted with an equal volume of $\mathrm{NaCl}$-saturated isopropanol until the upper (isopropanol) layer was clear and colorless, then once more. The DNA was 
dialyzed in boiled, sterile dialysis tubing against at least three changes of TE to remove $\mathrm{CsCl}$. An OD 260 reading was taken to determine the approximate concentration (at $260 \mathrm{~nm}, 1 \mathrm{OD}=50 \mathrm{ug} / \mathrm{ml}$ double-stranded DNA), and the plasmid was stored at $4^{\circ} \mathrm{C}$ or $-70^{\circ} \mathrm{C}$.

pfP $1450-3$ ' Isolation and Labeling

In order to obtain the P-450 cDNA fragment, the plasmid was digested with restriction enzymes, fragments separated by gel electrophoresis, and the cDNA band cut, eluted and precipitated. Two restriction enzymes, Eco RI and Pst $I$, digest the plasmid containing the P-450 fragment at unique sites, resulting in the $1.4 \mathrm{~kb} \mathrm{cDNA}$ fragment and a larger piece of pUC19. The digestion protocol summarized below was modified from Gingold (84), with gel electrophoresis carried out according to Maniatis et al. (84). A final volume of five times the plasmid volume was calculated and employed in order to avoid problems with possible contaminants in that preparation. pUC19-pfP ${ }_{1} 450-3$ ' was combined with 0.1 vol 10x Restriction Enzyme (RE) buffer (1x RE: $100 \mathrm{mM}$ Tris, pH 7.5/ 50 $\mathrm{mM} \mathrm{NaCl} / 10 \mathrm{mM} \mathrm{MgCl} / 1 \mathrm{mM} \mathrm{DTT}$, a mixture which appears suitable for both restriction enzymes) and sterile water. This mixture was twice mixed and briefly spun down in an Eppendorf 5415 microcentrifuge. Restriction enzymes (NE Biolabs or BRL) were added (5 U/hr/ug Pst I and 2U/hr/ug Eco RI) quickly and the solution mixed and spun down as above. The plasmid was digested for 1 to 1 $1 / 2$ hours at $37{ }^{\circ} \mathrm{C}$ and the reaction was stopped by the addition of 0.1 vol DNA Stop/ Loading buffer (20\% (w/v) sucrose/ 10\% (w/v) type 400 Ficoll/ $100 \mathrm{mM}$ EDTA/ 1\% (w/v) bromophenol blue). After mixing and spinning down, the digested DNA was stored on ice until it was prepared for loading onto a $0.8 \%$ agarose gel. 
A horizontal gel apparatus was prepared during the digestion. Agarose (type I, low EEO, Sigma) was melted in boiling 1x DNA Agarose Gel Running Buffer (10x stock: $0.9 \mathrm{M}$ Tris/ $25 \mathrm{mM} \mathrm{Na} 2 \mathrm{EDTA} / 0.9 \mathrm{M}$ boric acid, $\mathrm{pH} 8.2$ ) and poured into the gel apparatus after cooling to $60-70{ }^{\circ} \mathrm{C}$ (Maniatis et al., 84). The gel set within 1 hour and was overlaid with $1 \mathrm{x}$ Running Buffer. Sample (digested plasmid) and standards ( $1 \mathrm{~kb}$ DNA ladder and/or Hind III $\lambda$ digest, both from BRL, diluted in a loading buffer of $1 \%$ SDS/ $0.1 \%$ bromophenol blue/ $100 \mathrm{mM}$ EDTA/ $50 \%$ glycerol) were heated for 5 minutes at $65^{\circ} \mathrm{C}$ to denature the DNA and stored on ice, then loaded onto the gel with a capillary micropipetter (VWR). The gel was electrophoresed overnight at $40 \mathrm{~V}$ constant voltage.

The gel was stained with $\mathrm{EtBr}$, destained in 1x Running Buffer or water, and visualized under UV light (Transilluminator, Fotodyne, courtesy of Dr. Norm Wainwright, Associates of Cape Cod; or Dr. Douglas Prasher, WHOI) and photographed. The lower band (the 1.4 kb pfP $1450-3$ ' fragment) was excised, cut into small cubes and loaded into the large cup of an Isco Electroeluter (Gaastra and Jørgensen, 84). The outer buffer chambers contained 2x Electroelution Buffer and the inner chambers contained 1x Electroelution Buffer (10x stock: $68 \mathrm{mM}$ Tris/ $11 \mathrm{mM}$ citrate/ 2 mM EDTA, pH 8.2). The membranes were Spectraphor dialysis tubing (3,500 MW cut-off) which had been boiled in $2 \%$ sodium bicarbonate/ $1 \mathrm{mM}$ EDTA, rinsed, then boiled in $1 \mathrm{mM}$ EDTA and stored at $4^{\circ} \mathrm{C}$. Fresh membranes were used for each elution; sample cups were fitted with new membranes and tested for leaks prior to addition of the agarose cubes. The fragment was eluted for 4 to 6 hours at 3 watts into the small sample collection cup. The membrane tubing was examined briefly with a hand-held UV lamp to localize the DNA fragment, which was on or near the membrane on the anode 
side. The orange material was carefully collected by washing off membrane and extracted to remove agarose and $\mathrm{EtBr}$.

The DNA fragment was extracted twice with an equal volume of room temperature TE-saturated phenol (BRL), then extracted twice with 3 volumes (1:1) water/ diethyl ether (Mallinckrodt), precipitated with 0.1 vol $3 \mathrm{M}$ sodium acetate/ $10 \mathrm{mM} \mathrm{MgCl}_{2}$ plus 3 vol $95 \% \mathrm{EtOH}$ and stored several hours or overnight at $-20^{\circ} \mathrm{C}$ (Gaastra and Jorgensen, 84). The DNA was spun down in a cold microcentrifuge and the pellet was air-dried and washed twice with ether. After thoroughly drying the pellet, it was dissolved in 50 ul TE and an aliquot was diluted in TE. The OD 260 of this aliquot was measured to obtain an approximate concentration. A small volume of the diluted DNA was electrophoresed on a high voltage agarose mini-gel system to confirm its size and integrity, and its EtBr staining intensity was compared to that of a standard (Hind III $\lambda$ DNA) of known concentration to confirm its concentration. The DNA was stored at $4^{\circ} \mathrm{C}$ or $-70^{\circ} \mathrm{C}$.

One microgram of the $\mathrm{P}_{1} 450 \mathrm{cDNA}$ was nick-translated in the presence of $\left[{ }^{32} \mathrm{P}\right]-\mathrm{dCTP}$ according to the manufacturer's instructions (BRL Nick Translation Reagent Kit). The 45 ul reaction volume consisted of : a) a mixture containing $0.02 \mathrm{mM}$ of each of the three unlabeled nucleotide triphosphates (dATP, dGTP, dTTP) in Tris buffer, b) approximately 1 ug pfP $1450-3^{\prime}$ cDNA, and c) $156 \mathrm{pmol}(125 \mathrm{uCi}, 800 \mathrm{Ci} / \mathrm{mmol}$ at $10 \mathrm{mCi} / \mathrm{ml}$, Amersham) or $100 \mathrm{pmol}$ (300 uCi, $3000 \mathrm{Ci} / \mathrm{mmol}$ at $10 \mathrm{mCi} / \mathrm{ml}, \mathrm{ICN}$ ) labeled dCTP (deoxycytidine 5'[alpha-32P] triphosphate, triethylammonium salt) in a sterile $1.8 \mathrm{ml}$ Eppendorf tube. DNA Polymerase I/ DNase I was added, the mixture was gently shaken, centrifuged briefly, and incubated at $15^{\circ} \mathrm{C}$ for 1 hour. Stop Buffer $(0.1$ vol of 300 mM EDTA) was added and the labeled DNA was separated from unincorporated 
nucleotides by ethanol precipitation (Crouse and Amorese, 87) as described below.

The DNA was precipitated with 0.5 volumes of $7.5 \mathrm{M}$ ammonium acetate $\left(\mathrm{NH}_{4} \mathrm{OAc}\right)$ at room temperature and spun down after 20 minutes. The pellet was rinsed with 95\% EtOH, resuspended in $50 \mathrm{ul} \mathrm{TE}(\mathrm{pH} 7.5$ ) and reprecipitated. The pellet was again rinsed, resuspended in $50 \mathrm{ul} \mathrm{TE}$, and stored in the freezer $\left(-20^{\circ}\right)$ until use. Aliquots were taken at each step for total and TCA counts, to determine radiolabel incorporated into the cDNA and specific activity of the labeled cDNA. To obtain "total" counts, $1 \mathrm{ul}$ volumes were added directly to $3 \mathrm{ml}$ Scintiverse and counted. For TCA counts, $1 \mathrm{ul}$ was combined with $100 \mathrm{ul}$ of $200 \mathrm{ug} / \mathrm{ml}$ BSA carrier in a test tube, $2 \mathrm{ml}$ ice cold 5\% TCA was added and the mixture was vortexed and left on ice 10 minutes. The cloudy white precipitate was filtered through a GF-C disk (Whatman) on a sintered glass filter. The disk was rinsed once with $5 \mathrm{ml} 1 \%$ ice cold TCA and twice with $2 \mathrm{ml} \mathrm{95 \%} \mathrm{EtOH.} \mathrm{The} \mathrm{disk} \mathrm{was}$ air-dried, Scintiverse was added and the sample was counted in a Beckman LS 1801 liquid scintillation counter. Because $\left[{ }^{32} \mathrm{P}\right]$ has a very high counting efficiency even at high H\#s, no quench correction was necessary. Isolation of Genomic Teleost DNA

Genomic teleost DNA was isolated by a modification of Hewish and Burgoyne (73a and 73b), as briefly described by McMahon et al. (manuscript submitted). As discussed in Chapter 3, this method was chosen due to the high degree of nuclease (DNase) activity present during the more routine DNA isolation procedures. Approximately 1 gram of whole liver powder, which had previously been pulverized and stored in liquid nitrogen, was mixed with $10 \mathrm{ml}$ of ice-cold DNA Homogenization Buffer (1 x Burgoyne's buffer*/ 2 mM EDTA/ $0.5 \mathrm{mM}$ EGTA/ 0.34 M Sucrose) by vigorous shaking in a sterile $50 \mathrm{ml}$ capped centrifuge 
tube. The mixture was homogenized by hand in a chilled Dounce glass homogenizer (type "A") 10 to 15 times and overlaid onto $10 \mathrm{ml}$ of ice-cold DNA Cushion Buffer (1 x Burgoyne's buffer/ 0.1 mM EDTA/ 0.1 mM EGTA/ 0.5 M sucrose) in a fresh $50 \mathrm{ml}$ tube. The tube was centrifuged 10 minutes at $2000 \mathrm{rpm}$ and $0^{\circ} \mathrm{C}$ to spin nuclei through the cushion. Generally, a whitish/yellow pellet resulted. The supernate was poured off and the pellet drained briefly. Then $10 \mathrm{ml}$ of DNA Isolation Solution ( $150 \mathrm{mM} \mathrm{NaCl} / 10 \mathrm{mM}$ EDTA/ $10 \mathrm{mM}$ Tris, $\mathrm{pH} 7.5$ ) was added and the tube was shaken vigorously to resuspend the pellet. In quick succession, $0.4 \mathrm{ml} 10 \%$ SDS, $5 \mathrm{ml}$ TE-saturated phenol, and $5 \mathrm{ml}(24: 1)$ chloroform/isoamyl alcohol were added and the tube was inverted by hand $15-20$ times to mix thoroughly. The tube was then shaken for 1 hour at room temperature.

After a 10 minute, $2000 \mathrm{rpm}$, spin at room temperature, the upper (aqueous) layer was gently transferred to a new tube, leaving behind the interface. The DNA was reextracted two times with an equal volume of (1:1) phenol: chloroform and one time with an equal volume of chloroform. Solid ammonium acetate was then added to a concentration of 1.5 to $2 \mathrm{M}$. Two volumes cold $100 \%$ EtOH were added and the tube was inverted several times to precipitate the DNA. A sharp rap on the benchtop settled the DNA, which was then wound out on a sterile glass rod, dipped into $70 \% \mathrm{EtOH}$ followed by $100 \% \mathrm{EtOH}$ to rinse, and briefly air-dried. The DNA was then unwound and dissolved in $5 \mathrm{ml} \mathrm{TE}(\mathrm{pH}$ 8.0). RNase was added to $100 \mathrm{ug} / \mathrm{ml}$ and the DNA was incubated 1 hour at $37^{\circ} \mathrm{C}$. Proteinase $\mathrm{K}$ was added to $200 \mathrm{ug} / \mathrm{ml}$, and the mixture was incubated at least 3 hours or overnight at $37^{\circ} \mathrm{C}$.

The DNA was again reextracted (e.g., 2 times with (1:1) phenol:chloroform, 1 time with chloroform), precipitated by the addition of 
ammonium acetate to $2 \mathrm{M}$, and wound out, rinsed, and dissolved in a smaller volume of TE. Genomic DNA was stored at $4^{\circ} \mathrm{C}$.

*Burgoyne's buffer (Hewish and Burgoyne, 73a and 73b): $60 \mathrm{mM} \mathrm{KCl}$ / $15 \mathrm{mM} \mathrm{NaCl} / 15 \mathrm{mM}$ Tris, $\mathrm{pH}$ 7.5/ $1.5 \mathrm{mM}$ spermine/ $5 \mathrm{mM}$ spermidine).

\section{$\underline{\text { Southern (Genomic) Blots }}$}

Scup, rainbow trout, and Fundulus hepatic genomic DNA (15 ug of each, precipitated with $0.5 \mathrm{vol} 7.5 \mathrm{M}$ ammonium acetate plus $2.5 \mathrm{vol} 95 \% \mathrm{EtOH}$ and resuspended in fresh TE) were digested overnight with Pst 1 ( $80 \mathrm{U})$ or Eco $R I$ (30 U) or both, separated on an $0.8 \%$ agarose gel, and stained with $\mathrm{EtBr}$ as described above for purification of $\mathrm{pfP}_{1} 450-3^{\prime} \mathrm{cDNA}$. After visualization and further destaining, the gel was placed in $0.25 \mathrm{M} \mathrm{HCl}$ for 10 minutes, rinsed, and incubated in Denaturing Solution (1.5 M NaCl/ $0.5 \mathrm{M} \mathrm{NaOH})$ for 1 to 2 hours. The gel was rinsed again, then left in Neutralizing Solution $(1.5 \mathrm{M} \mathrm{NaCl} / 1 \mathrm{M}$ Tris, $\mathrm{pH}$ 8.0) for 1 hour. Transfer to 0.45 micron nitrocellulose (Schleicher and Schuell) was carried out in 10x ssc (20x ssc stock: $3.0 \mathrm{M} \mathrm{NaCl} / 0.30 \mathrm{M}$ citrate, $\mathrm{pH}$ 7.0) essentially as described by Maniatis et al. (84). The residual gel showed no bands after extensive staining with EtBr. The nitrocellulose was baked and stored at $4^{\circ} \mathrm{C}$ until use.

The nitrocellulose was pre-hybridized for 2 hours at $65^{\circ} \mathrm{C}$ in $6 \mathrm{x} \mathrm{ssc}$, 0.5\% SDS, 5x Denhardt's Solution (50x stock: 1\% (w/v) Ficoll/ 1\% (w/v) polyvinylpyrrolidane/ $1 \%(\mathrm{w} / \mathrm{v}) \mathrm{BSA}$ ) and $100 \mathrm{ug} / \mathrm{ml}$ sheared E. coli DNA (Sigma). The filter was transferred to hybridization mixture of the same composition with the addition of $10 \mathrm{mM}$ EDTA and $2 \times 10^{7} \mathrm{cpm}\left[{ }^{32} \mathrm{P}\right] \mathrm{cDNA}$, and incubated at $65^{\circ} \mathrm{C}$ overnight. Washes consisted of $2 \mathrm{x}$ ssc, $0.5 \%$ SDS and $2 \mathrm{x}$ ssc, $0.1 \%$ SDS. The nitrocellulose was dried, labeled with $\left[{ }^{14} \mathrm{C}\right]$-glycine ink 
spots and autoradiography performed at $-70^{\circ} \mathrm{C}$. Kodak X-Omat film was placed between two Cronex Lightning Plus shields (Dupont) as described by Maniatis et al. (84).

\section{Northern (RNA) Blots}

For Northern blots, RNA was isolated from liver homogenates as described previously (Chapter 3) and 15 ug total RNA per lane was loaded onto $1.0 \%$ agarose/ formaldehyde gels by a modification of the procedure of Gerard and Miller (86). Gel electrophoresis was carried out in a hood. Agarose was melted in water and cooled to $60^{\circ} \mathrm{C}$. The dissolved agarose was stirred while formaldehyde $(37 \%=12.3 \mathrm{M})$ and RNA Running Buffer $(5 \mathrm{x}$ stock: $5 \mathrm{mM}$ MOPS/ 0.2 M EDTA, pH 7.0) were added to final concentrations of $2.2 \mathrm{M}$ and $1 \mathrm{x}$, respectively. The mixture was poured immediately into a horizontal gel apparatus and samples were prepared. RNA samples were combined with a mixture to obtain a final composition of $0.5 \mathrm{x}$ Running Buffer/ $2.2 \mathrm{M}$ formaldehyde/ $50 \%$ deionized formamide. The gel was pre-electrophoresed for 30 minutes at $60 \mathrm{~V}$. Meanwhile, the samples were heated at $65^{\circ} \mathrm{C}$ for 10 to 15 minutes to denature the RNA, plunged into ice, and 0.1 vol Loading buffer (50\% (v/v) glycerol/ $0.4 \%(w / v)$ bromophenol blue/ $0.4 \%(w / v)$ xylene cyanol/ $1 \mathrm{mM}$ EDTA) was added to each. RNA molecular weight standards (RNA ladder, BRL) were generally included in the same gel. Samples and standards were loaded with a micropipettor and the gel was run at $60 \mathrm{~V}$ for 1 hour, then $100 \mathrm{~V}$ for several hours. Buffer was exchanged between the chambers half-way through the run.

The gel was stained in a foil-covered glass dish for 5 minutes $(5 \mathrm{ug} / \mathrm{ml}$ $\mathrm{EtBr}$ in water) and destained in water in the dark for up to 2 hours. Photographs were taken and the RNA was transferred to nitrocellulose ( 0.45 micron, Schleicher and Schuell or Millipore) overnight with 10x ssc. The nitrocellulose was air dried 
without rinsing, then baked in a conventional oven at $75^{\circ} \mathrm{C}$ for 2 hours, and stored, desiccated, at $4^{\circ} \mathrm{C}$ until use. Nitrocellulose strips corresponding to standard lanes were excised from the filter after baking, soaked in 5\% acetic acid for 15 minutes, stained with methylene blue ( $0.5 \mathrm{M} \mathrm{NaAcetate} / 0.04 \%$ methylene blue) for 15 minutes, and destained in water.

Prior to hybridization, the nitrocellulose was floated in $5 \mathrm{x}$ ssc for at least 2 minutes, then placed in a hybridization bag (BRL). The nitrocellulose was prehybridized, shaking, for 1 to 2 hours at $42^{\circ} \mathrm{C}$ in $50 \%$ deionized formamide, $5 \mathrm{x}$ Denhardts, $0.5 \%$ SDS, $5 \mathrm{x}$ ssc and $100 \mathrm{ug} / \mathrm{ml}$ sheared E. coli DNA. This mixture was replaced with hybridization mixture (pre-hybridization mixture plus $2 \times 10^{7}$ cpm or $\left.5.8 \times 10^{7} \mathrm{cpm}\left[{ }^{32} \mathrm{P}\right] \mathrm{pfP}_{1} 450-3^{\prime} \mathrm{cDNA}\right)$ and the nitrocellulose was incubated, shaking, at $42^{\circ} \mathrm{C}$ for about 20 hours. Washes consisted of $2 \mathrm{x}$ ssc, $0.5 \%$ SDS; $2 x$ ssc, $0.1 \%$ SDS; $1 \mathrm{x}$ ssc, $0.1 \%$ SDS; and $0.5 \mathrm{x}$ ssc, $0.1 \%$ SDS, the latter washes at $55^{\circ} \mathrm{C}$. Alternatively, washes consisted of $2 \mathrm{x}$ ssc, $0.5 \%$ SDS, 5 min rm temp; $2 \mathrm{x} \mathrm{ssc}, 0.1 \%$ SDS, $15 \mathrm{~min} \mathrm{rm}$ temp; $2 \mathrm{x} \mathrm{ssc}, 0.1 \% \mathrm{SDS}, 55^{\circ} \mathrm{C}, 15$ $\min ; 1 \mathrm{x} \mathrm{ssc}, 0.1 \% \mathrm{SDS}, 55^{\circ} \mathrm{C}, 15 \mathrm{~min} ; 0.5 \mathrm{x} \mathrm{ssc}, 0.1 \% \mathrm{SDS}, 55^{\circ} \mathrm{C}, 15 \mathrm{~min}$. Autoradiography was carried out as described above for Southern blots. Bands were scanned with a Helena Labs Densitometer (courtesy of Dr. Stanley Watson, Cape Cod Associates, Falmouth, MA) in the transmission mode.

\section{RESULTS}

\section{Plasmid and cDNA Isolation and Characterization}

An approximately $4.1 \mathrm{~kb}$ pUC19 plasmid containing a $\mathrm{P}_{1} 450 \mathrm{cDNA}$ from MC-treated rainbow trout, $\mathrm{pfP}_{1} 450-3$ ', has been prepared and described by Heilmann et al. (88). Figure 4-1 illustrates the main features of the plasmid and insert. pUC19 contains a fragment of the pBR322 plasmid which carries an 


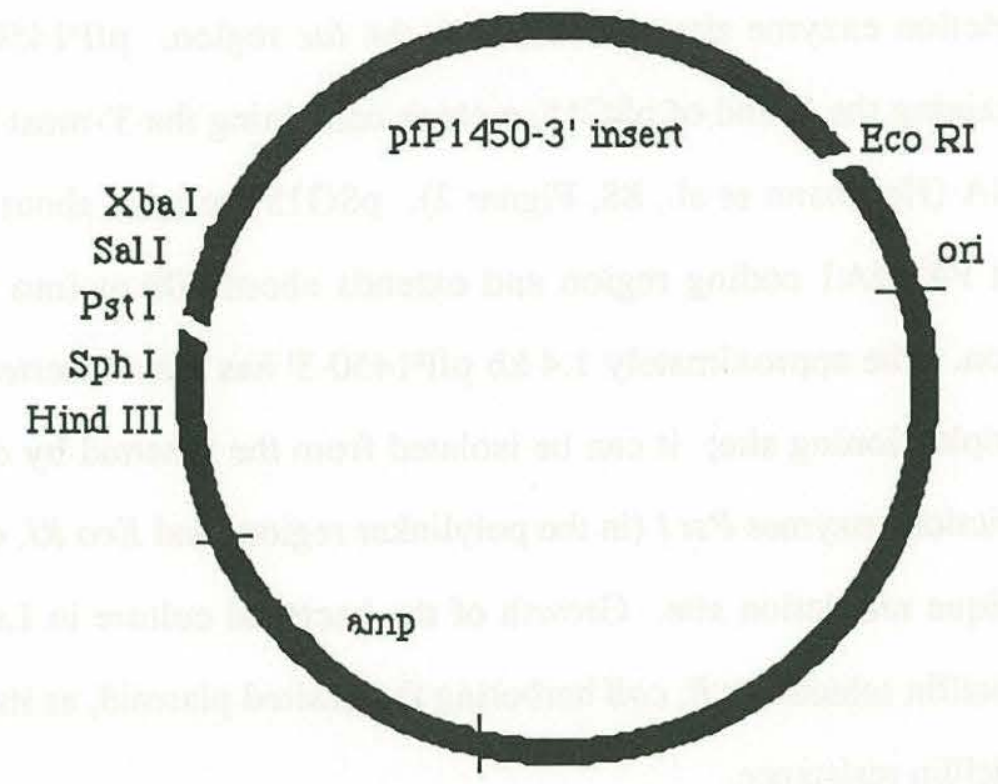

FIGURE 4-1: Non-artist's rendition of plasmid pUC19-P $1450-3$ '

The plasmid is double stranded DNA, with a total size of about $4.1 \mathrm{~kb}$. The P-450 insert can be cleaved from the pUC19 portion by digestion with Pst I and Eco RI, each of which cuts this construct only once. In the pUC19 plasmid, the multiple cloning site contains the following restriction sites: Eco RI, Sst I, Kpn I, Sma I, Bam HI, Xba I, Sal I, Pst I, Sph I, Hind III. The P-450 cDNA is inserted between the Eco RI and XbaI sites, destroying the intervening sites. (amp = ampicillin resistance gene, lactamase; ori $=$ origin of replication $).$ 
ampicillin resistance gene (B-lactamase), an origin of replication, and a portion of the lac $\mathrm{Z}$ gene. A multiple cloning region containing a number of unique restriction enzyme sites is located in the lac region. pfP1450-3' is a subclone containing the 3 ' end of pSG15, a clone containing the 3'-most 2060 bases of the cDNA (Heilmann et al., 88, Figure 2). pSG15 includes about two-thirds of the trout P450IA1 coding region and extends about $600 \mathrm{nt}$ into the $3^{\prime}$ noncoding region. The approximately $1.4 \mathrm{~kb}$ pfP1450-3' has been inserted into the pUC19 multiple cloning site; it can be isolated from the plasmid by digestion with the restriction enzymes Pst I (in the polylinker region) and Eco RI, each of which has a unique restriction site. Growth of the bacterial culture in Luria medium plus ampicillin selects for $E$. coli harboring the desired plasmid, as its presence confers ampicillin resistance.

A small amount of the plasmid was digested with each restriction enzyme alone (single cut $=$ linearization) and both together (two cuts $=$ fragmentation) under the conditions outlined in Materials and Methods. The digests were electrophoresed on a $0.8 \%$ agarose gel and stained with EtBr. Digestion with either enzyme alone resulted in linearization of the plasmid, with a single band of approximately $4 \mathrm{~kb}$ (Figure 4-2, lanes 4 and 6). The very faint, higher MW bands (lane 6) are probably concatamers of uncleaved plasmid. Simultaneous digestion with Eco R1 and Pst 1 resulted in two smaller bands, of approximately 2.6 and $1.4 \mathrm{~kb}$ (lane 2). The lower band corresponds to the cDNA fragment, while the upper band represents the remainder of the pUC19 plasmid. Thus, this simultaneous digestion protocol can be used to successfully obtain the $P_{1} 450$ cDNA fragment from the plasmid. 


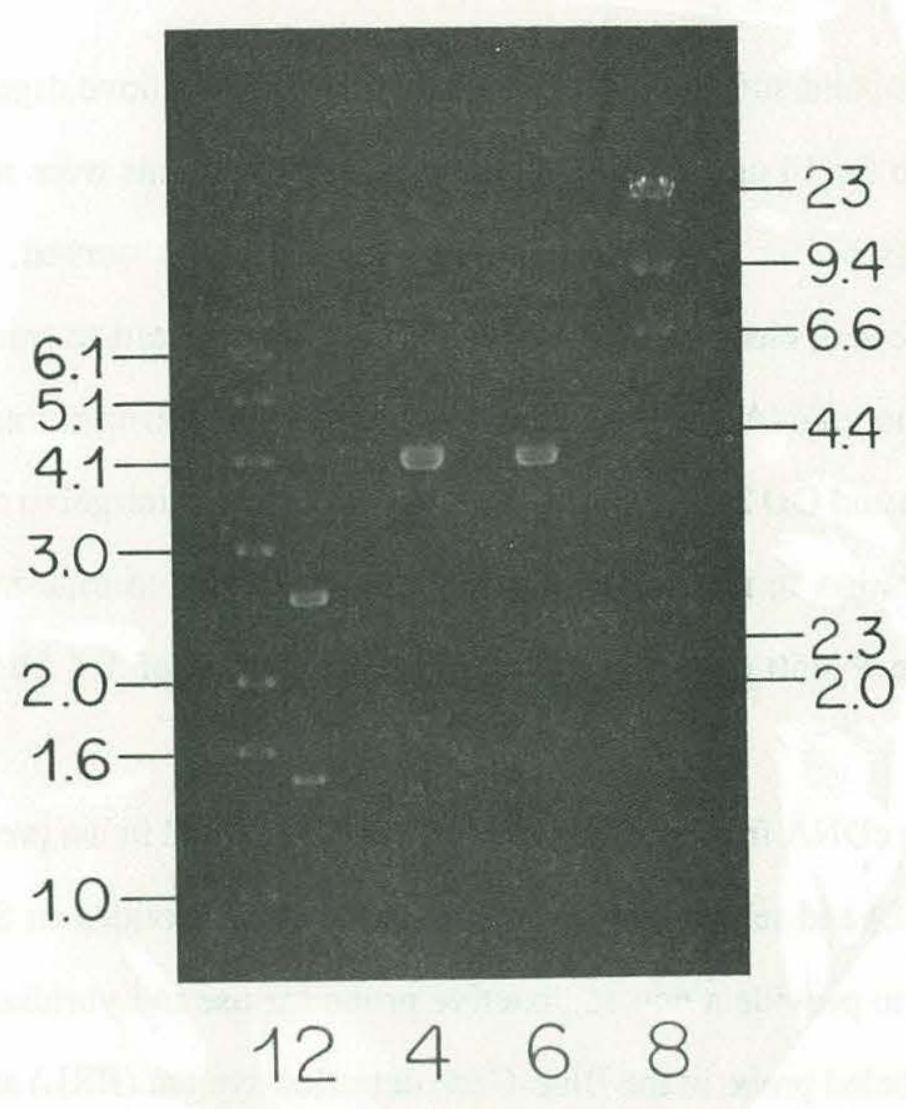

FIGURE 4-2: Restriction digestion of plasmid pUC19-pfP ${ }_{1}^{450-3 ' . ~}$

The plasmid was digested with $5 \mathrm{U} / \mathrm{hr} / \mathrm{ug}$ Pst I and/or $2 \mathrm{U} / \mathrm{hr} / \mathrm{ug}$ Eco RI as described in the Materials and Methods section. Standard fragment size, in kilobasepairs, is shown for lanes 1 and 8 .

Lane1: $1 \mathrm{~kb}$ DNA ladder standard (5 ug, BRL); lane 2: Eco RI and Pst I digest; lane 4: Pst I digest; lane 6: EcoRI digest; lane 8: $\lambda$ Hind III digest ( 3 ug, BRL). 
To obtain sufficient material for labeling, the above digestion protocol was scaled up for 14 ug plasmid and the resulting fragments were separated on an agarose gel as before. The same banding pattern was observed, and the lower band was excised, electroeluted, extracted and precipitated to remove $\mathrm{EtBr}$ and phenol. The cDNA fragment was examined spectrophotometrically for concentration and OD 260/280 ratio, and separated on a mini-gel to confirm its size and concentration in relation to known standards prior to nick-translation. As expected, the $\mathrm{P}_{1} 450 \mathrm{cDNA}$ constituted a single band of $1.4 \mathrm{~kb}$ size (data not shown).

The cDNA fragment was initially nick-translated in the presence of biotin 7-dATP (BRL) and separated from unincorporated nucleotides on Sephadex G-50 (Pharmacia) to provide a non-radioactive probe for use in hybridizations. Use of this biotin-labeled probe in the Blue-Gene detection system (BRL) according to the manufacturer's instructions was unsuccessful, resulting in high and variable backgrounds and no specific banding when used to probe a Northern blot of Fundulus RNA. Subsequent labeling was accomplished by nick-translation in the presence of [32P]-labeled dCTP, a more conventional and sensitive method. Table 4-1 shows the results of a single nick-translation reaction. In this case, approximately $21 \%$ of the labeled dCTP was incorporated into the cDNA fragment, resulting in a specific activity of about $6.2 \times 10^{7} \mathrm{cpm} / \mathrm{ug}$. The radiolabeled cDNA was used in hybridizations within one half-life of labeling. 
Table 4-1: Nick Translation of $\operatorname{pfP}_{1} 450-3^{\prime}$

ID $\mathrm{cpm}^{\mathrm{b}}$ $\mathrm{uCic}$ Comments

T1

997,558

131.5

Total starting material, desired $125 \mathrm{uCi}$

TCA1

21,417

$\mathrm{T} 2$

738,357

97

TCA2

4,635

0.5

Unincorporated nucleotides (nt)

TCA counts should be very low:

supernate should be free nt only

T3

292,667

35

Ideally, $\mathrm{T} 2+\mathrm{T} 3=\mathrm{T} 1(97+35=132)$

TCA3 34,365

$\mathrm{T} 4$

4,029

0.5

T4 and TCA4 should be very low:

TCA4

546

removed most free $\mathrm{nt}$ in the first ppt

$\mathrm{T} 5$ $1,238.605$

$28.221 \%$ incorporation. $6.2 \times 10^{7} \mathrm{cpm} / \mathrm{ug}$

a ID = identity of sample, $\mathrm{T}=$ total counts, $\mathrm{TCA}=$ acid-precipitable counts $1=$ nick trans mix $+\mathrm{NH}_{4} \mathrm{OAc}+\mathrm{EtOH}$, sampled during incubation (290 ul) $2=\# 1$ precipitated, supernate sampled

$3=$ resuspended pellet $+\mathrm{NH}_{4} \mathrm{OAc}+\mathrm{EtOH}$, sampled during incubation ( $263 \mathrm{ul}$ )

$4=\# 3$ precipitated, supernate sampled

$5=$ pellet resuspended in $50 \mathrm{ul} \mathrm{TE}$

b Raw cpm for each $1 \mathrm{ul}$ aliquot

c Microcurie values, after volume correction (e.g., T5 counts x 50 ul total volume equals $6.2 \times 10^{7} \mathrm{cpm}$, or $28.2 \mathrm{uCi}$ ) 
$\underline{\text { Southern Blot Analysis }}$

To determine whether labeling of the cDNA probe with [32P]-dCTP had been successful, and to test for cross-reactivity of the probe, labeled $\mathrm{pfP}_{1} 450-3^{\prime}$ was hybridized with several teleosts species in a Southern blot prior to its use in Northern hybridizations. Agarose gel electrophoresis of scup, trout, and Fundulus DNA prior to restriction enzyme digestion resolved a single, tight band of high molecular weight material for each, indicating that in all three cases genomic DNA had been isolated, with negligible degradation to smaller fragments (which would occur as smears of EtBr-staining material). Overnight digestion with the two restriction enzymes followed by gel electrophoresis yielded DNA from each species that appeared as a smear on an agarose gel, indicating that DNA fragments of many sizes had been generated (data not shown). This digested, size-separated DNA was transferred to nitrocellulose and hybridized with the [32P]-labeled trout cDNA. Distinct bands were observed in each lane (Figure 4-3).

Each species showed a unique pattern of cross-reactivity with the trout cDNA. Rainbow trout hepatic DNA (lanes 4-6) served as a positive control, as the cDNA was derived originally from trout liver mRNA. In the Pst I and PstI/Eco $R 1$ digested samples, two strong bands of approximately 2.5 and $4.5 \mathrm{~kb}$ were visible, indicating the possibility of two trout genes. Scup DNA, tested due to the wealth of background information on scup P-450E, gave a single discrete band of about $6.6 \mathrm{~kb}$ when digested with both REs, with a signal as strong as that seen for the trout (lanes 1-3). The strength of the signals indicates similar recognition of the trout and scup genes by the $\mathrm{P}_{1} 450$ probe. This supports immunological (Chapter 2; Kloepper-Sams et al., 87) and sequencing results (see Table 3-5) indicating that the $\mathrm{P}-450$ protein orthologues in these two species are structurally 
related. The Fundulus DNA digested with Pst I and PstI/Eco RI exhibited a single labeled band at about $3.4 \mathrm{~kb}$, but also showed some smearing, a condition which may have been due to overloading of the lanes or degradation of the DNA by nucleases (lanes 7-9). Nevertheless, the general conclusion from this study is that the trout cDNA is an acceptable probe to use in analyzing the RNA from these three teleost species, including RNA from treated and control Fundulus.

Induction of P-450E Activity and Protein Levels - Short term Study

Once the methods of measuring P-450E mRNA were established, I conducted a short term Fundulus induction experiment to elucidate the temporal relationship between increases in P-450E mRNA and protein levels. Fish were treated with $50 \mathrm{mg} / \mathrm{kg} \mathrm{BNF}$ as before (Chapter 3) and sampled every six hours for the first 24 hours, then every eight hours for the next 24 hours. As in the experiments described in Chapter 3, hepatic P-450 and b5 specific content, EROD enzyme activity, and P-450E protein were all assayed to ensure that the RNA samples represented values from inducible/induced animals. Over this short time, as expected, the specific content of spectral P-450 and b5 did not change in control or BNF-treated fish (Table 4-2). EROD activity in BNF-treated animals was significantly elevated compared to control values by 32 hours and continued to rise over the rest of the time course. As in the 20 day (long term) experiment, the temporal trend of EROD activity levels was similar when expressed as turnover number (nmol/min/nmol P-450) and specific activity (nmol/min/mg protein). The magnitude and temporal pattern of EROD specific activity in the short term (48 hr) experiment fit well into the EROD activity pattern observed in the long term (20 day) experiment. The consistency of the pattern of EROD activity in the short and long term experiments indicates that the increases observed in the short term experiment reflect induced expression of P-450E. 
FIGURE 4-3: Southern blot of scup, trout, and Fundulus genomic DNA, hybridized to [32P]-labeled trout $\mathrm{pfP}_{1} 450-3$ ' cDNA

Genomic DNA was isolated, cleaved with restriction enzymes and separated on a $0.8 \%$ agarose gel. Hybridization conditions are described in the Materials and Methods section. Molecular weight markers were run in lane 10 and stained separately. ( $\lambda$ Hind III digest (BRL) was electrophoresed as in Figure 4-2, lane 8.) Lanes 1-3: scup DNA, lanes 4-6: rainbow trout DNA, lanes 7-9: Fundulus DNA. Lanes 1, 4, and 7: Pst I; lanes 2, 5 and 8: Eco Rl plus Pst I; and lanes 3, 6 and 9: Eco RI. 
(Figure 4-3)

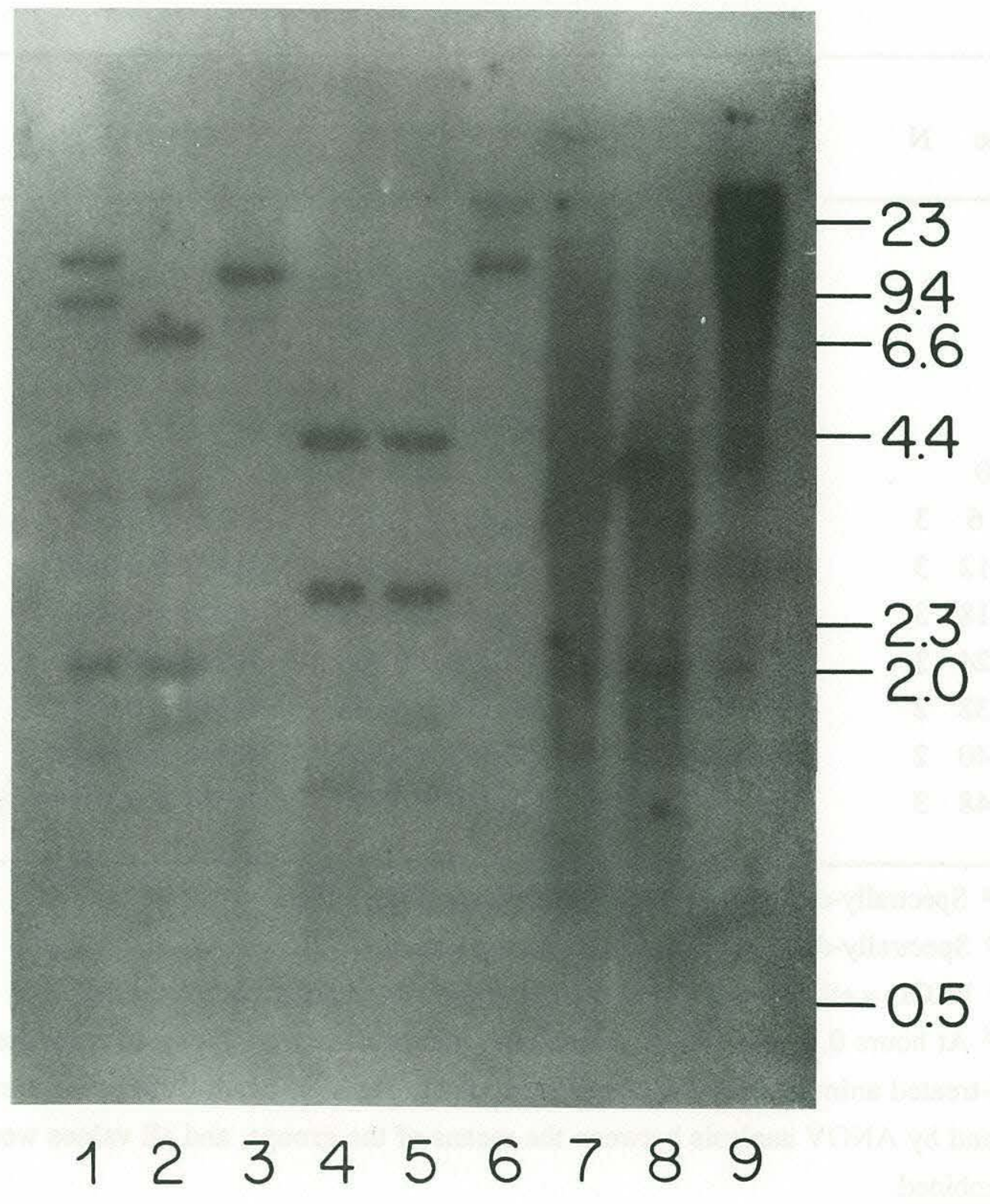




\section{TABLE 4-2:}

Monooxygenase parameters in Fundulus following BNF treatment, 48 hours

\begin{tabular}{|c|c|c|c|c|}
\hline time & $\mathrm{N}$ & $b_{5}{ }^{a}$ & $\mathrm{P}-450^{\mathrm{b}}$ & ERODC \\
\hline & & \multicolumn{3}{|c|}{ Control Group Means ${ }^{d}$} \\
\hline & & $50.1 \pm 12.3$ & $0.175 \pm 0.048$ & $0.179 \pm 0.073$ \\
\hline & & \multicolumn{3}{|c|}{ Pools from BNF-treated Animals } \\
\hline hr 0 & & $n d^{e}$ & nd & nd \\
\hline hr 6 & 3 & $49.0 \pm 6.7$ & $0.161 \pm 0.033$ & $0.189 \pm 0.049$ \\
\hline hr 12 & 3 & $40.6 \pm 5.3$ & $0.133 \pm 0.046$ & $0.177 \pm 0.052$ \\
\hline hr 18 & 3 & $51.6 \pm 2.4$ & $0.164 \pm 0.066$ & $0.230 \pm 0.057$ \\
\hline hr 24 & 3 & $54.9 \pm 22.5$ & $0.178 \pm 0.067$ & $0.253 \pm 0.102$ \\
\hline hr 32 & 2 & $59.4 \pm 6.0$ & $0.174 \pm 0.011$ & $0.341 \pm 0.027 *$ \\
\hline hr 40 & 2 & $40.9 \pm 8.1$ & $0.143 \pm 0.061$ & $0.345 \pm 0.081^{*}$ \\
\hline $\mathrm{hr} 48$ & 3 & $45.4 \pm 12.4$ & $0.149 \pm 0.023$ & $0.557 \pm 0.101^{* *}$ \\
\hline
\end{tabular}

a Spectrally-determined cytochrome $\mathrm{b}_{5}, \mathrm{pmol} / \mathrm{mg}$ protein

b Spectrally-determined $\mathrm{P}-450, \mathrm{nmol} / \mathrm{mg}$ protein

c EROD = ethoxyresorufin O-deethylase activity, $\mathrm{nmol}$ product $/ \mathrm{min} / \mathrm{mg}$

d At hours 0, 6, 12, 18, 24, 40, and 48, microsomes were prepared from corn oil-treated animals ( $n=3$ or 2 per timepoint). No significant differences were found by ANOV analysis between the means of the groups, and all values were combined.

e $\mathrm{nd}=$ value not determined

Values significantly different from pooled control values by Dunnett's test (Zar, 74): $* P<0.05, * * P<0.01$ 
P-450E protein levels were elevated at the later time points examined. $\mathrm{P}-450 \mathrm{E}$ on a per mg microsomal protein basis was significantly higher than control values at 48 hours $(P<0.05)$ and $\mathrm{P}-450 \mathrm{E}$ as a percent of total spectral $\mathrm{P}-450$ was significantly elevated at $40(P<0.05)$ and $48(P<0.01)$ hours after BNF treatment. The EROD and P-450E values exhibited a coincident rise (Figure 4-4) and, as was seen in the long term experiment, no lag was apparent between the increases in EROD activity and P-450E protein levels. Induction of P-450E mRNA Levels - short term study

In vitro translation and immunoprecipitation analyses were conducted with Fundulus RNA from each time point of the 48 hour experiment. Visual observation and densitometric scans of fluorograms (values from a representative fluorogram, Figure 4-5) showed that the content of P-450E-specific translatable RNA remained below the limits of detection in the corn oil controls. The hepatic RNA from all BNF-treated animals, however, gave detectable signals. A single band was evident by 6 hours after treatment and the response increased dramatically up to 40 hours, then declined slightly. Other analyses of RNA from these fish showed a plateau at 40 to 48 hours (data not shown).

Because the translation/immunoprecipitation method did not show detectable signal in control animals, it seemed wise to attempt a more direct, and perhaps more sensitive, method. As a second method of measuring mRNA levels, I directly probed size-separated RNA from control and induced fish with radiolabeled pfP $1450-3$ ', the cDNA derived from trout $\mathrm{P}_{1} 450$ mRNA.

Total RNA from control and BNF-treated Fundulus exhibited two EtBrstaining bands after formaldehyde/ agarose gel electrophoresis. These two bands correspond to the $28 \mathrm{~S}$ and $18 \mathrm{~S}$ rRNA moieties, which are the predominant RNA species in total RNA samples ${ }^{1}$. The [32P]-labeled trout $\mathrm{P}_{1} 450 \mathrm{cDNA}$ hybridized 
Figure 4-4

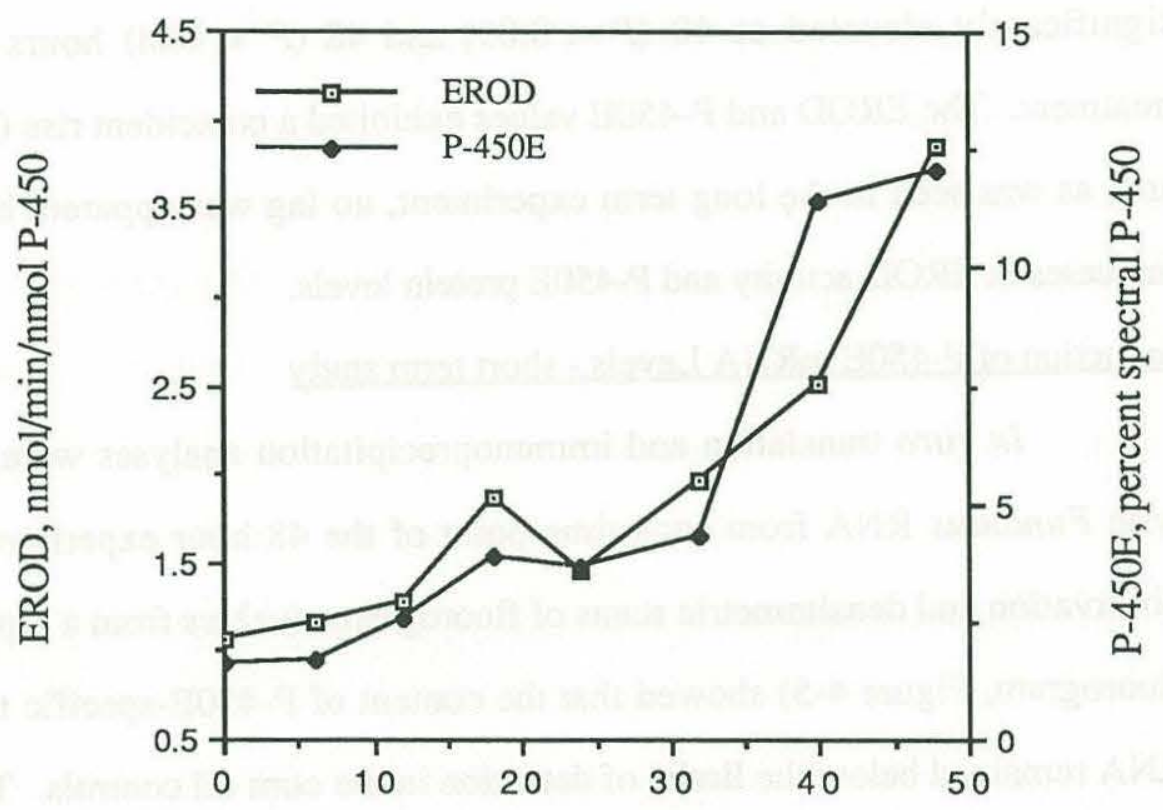

Hours after Treatment

FIGURE 4-4: Relationship between Fundulus P-450E protein levels and EROD activity following BNF treatment, 48 hour experiment

P-450E protein (closed diamonds) and EROD activity (open squares) were measured as described in the Materials and Methods section. Control P-450E means ranged from 1.6 to $2.2 \%$, and control EROD means ranged from 0.80 to 1.8 . 
Figure 4-5

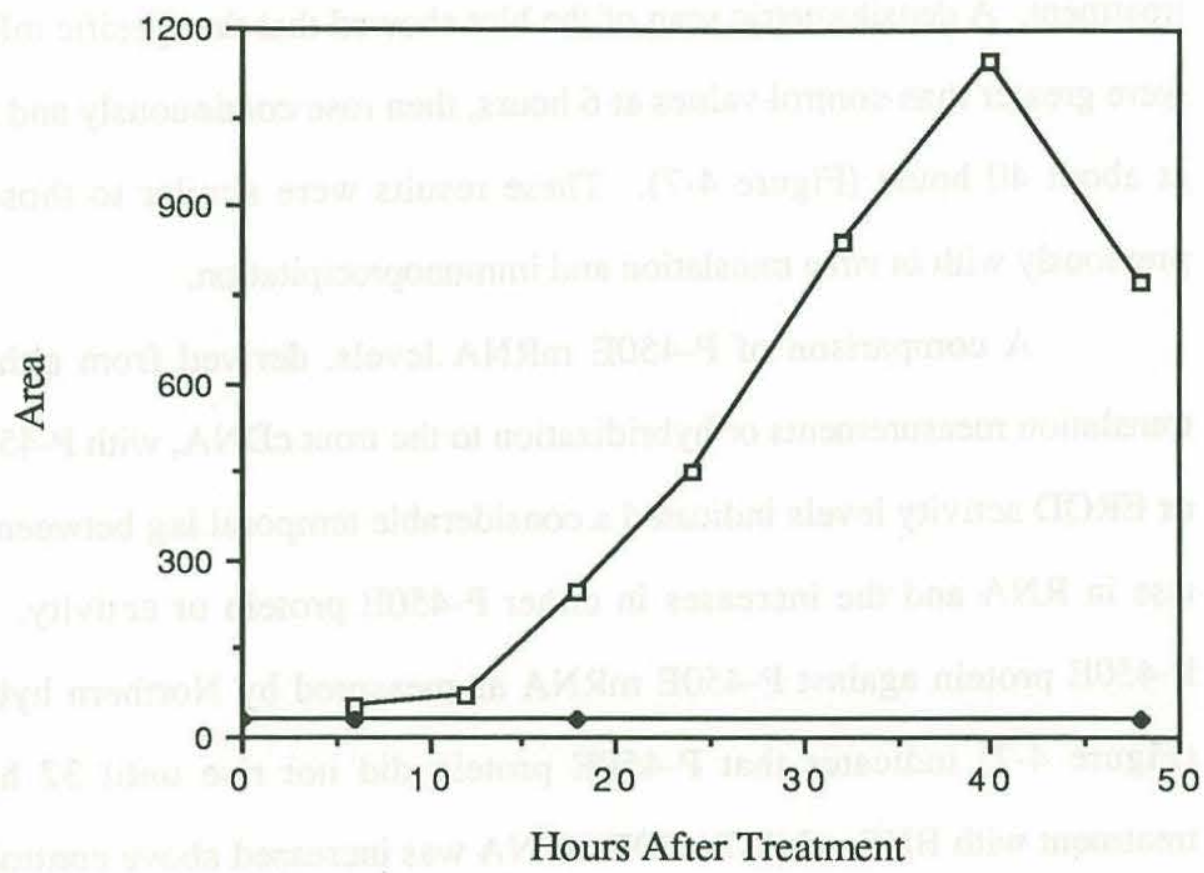

FIGURE 4-5: Immunoprecipitated in vitro translation products (P-450E) from Fundulus following BNF treatment , 48 hour experiment

Ten micrograms RNA from each time point was translated and precipitated with polyclonal anti-P450E as described in Chapter 3. Fluorograms were scanned with a densitometer, and the curves were integrated and values reported as arbitrary units. Control animal samples (closed diamonds) all had values below 30 , the limit of detection. BNF-treated animals are shown by open squares. Values from one representative analysis are shown; the experiment was repeated at least in triplicate with the same and duplicate RNA samples with similar results. 
to a single band of $M_{r}$ between 2 and $4 \mathrm{~kb}$ in each lane (Figure 4-6). The signal was faint but detectable in the control sample, and increased with time after BNF treatment. A densitometric scan of the blot showed that the specific mRNA levels were greater than control values at 6 hours, then rose continuously and leveled off at about 40 hours (Figure 4-7). These results were similar to those obtained previously with in vitro translation and immunoprecipitation.

A comparison of $\mathrm{P}-450 \mathrm{E}$ mRNA levels, derived from either in vitro translation measurements or hybridization to the trout cDNA, with P-450E protein or EROD activity levels indicated a considerable temporal lag between the initial rise in RNA and the increases in either P-450E protein or activity. A plot of P-450E protein against P-450E mRNA as measured by Northern hybridization (Figure 4-7) indicates that P-450E protein did not rise until 32 hours after treatment with BNF, while P-450E mRNA was increased above control levels by 6 hours after treatment. A similar result was observed when EROD activity rather than protein values were plotted against RNA from the in vitro translation or Northern blot analyses (data not shown).

\section{Decline in P-450E mRNA Content}

To determine whether a secondary peak in P-450E mRNA content, or maintenance of moderate levels of the mRNA could be responsible for the continued presence of $\mathrm{P}-450 \mathrm{E}$ protein and activity levels beyond 48 hours after BNF treatment (e.g., Figure 3-1), Fundulus were treated with $50 \mathrm{mg} / \mathrm{kg} \mathrm{BNF}$ as before and sampled at $0,1,2,4,5,8$, and 13 days. P-450E mRNA levels were measured at each time point, and microsomal P-450E protein and EROD activity were analyzed on days $0,2,5,8$, and 13 . The microsomal parameters were examined primarily to confirm that induction was occurring in these Fundulus. Consistent with our earlier findings, hepatic microsomal EROD activity rose 


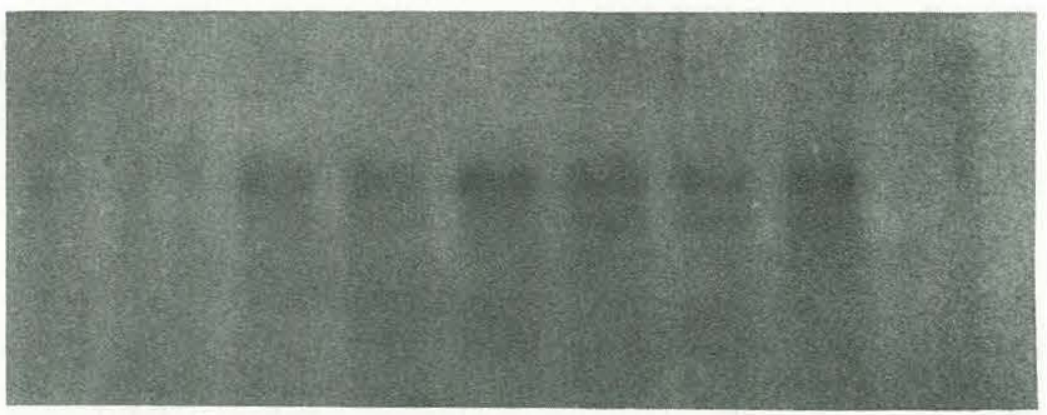

\section{$\begin{array}{lllllllll}1 & 2 & 3 & 4 & 5 & 6 & 7 & 8\end{array}$}

FIGURE 4-6: Northern blot of Fundulus RNA, hybridized to [32-P]-labeled $\operatorname{pfP}_{1} 450-3$ ' trout cDNA

Total RNA was isolated from BNF-treated fish as outlined in Chapter 3 and the blot performed as described in the Materials and Methods section.

Lane 1: 0 hour control; lane 2: 6 hour BNF; lane 3: 12 hour BNF; lane 4: 18 hour BNF; lane 5: 24 hour BNF; lane 6: 32 hour BNF; lane 7: 40 hour BNF; and lane 8: 48 hour BNF. 


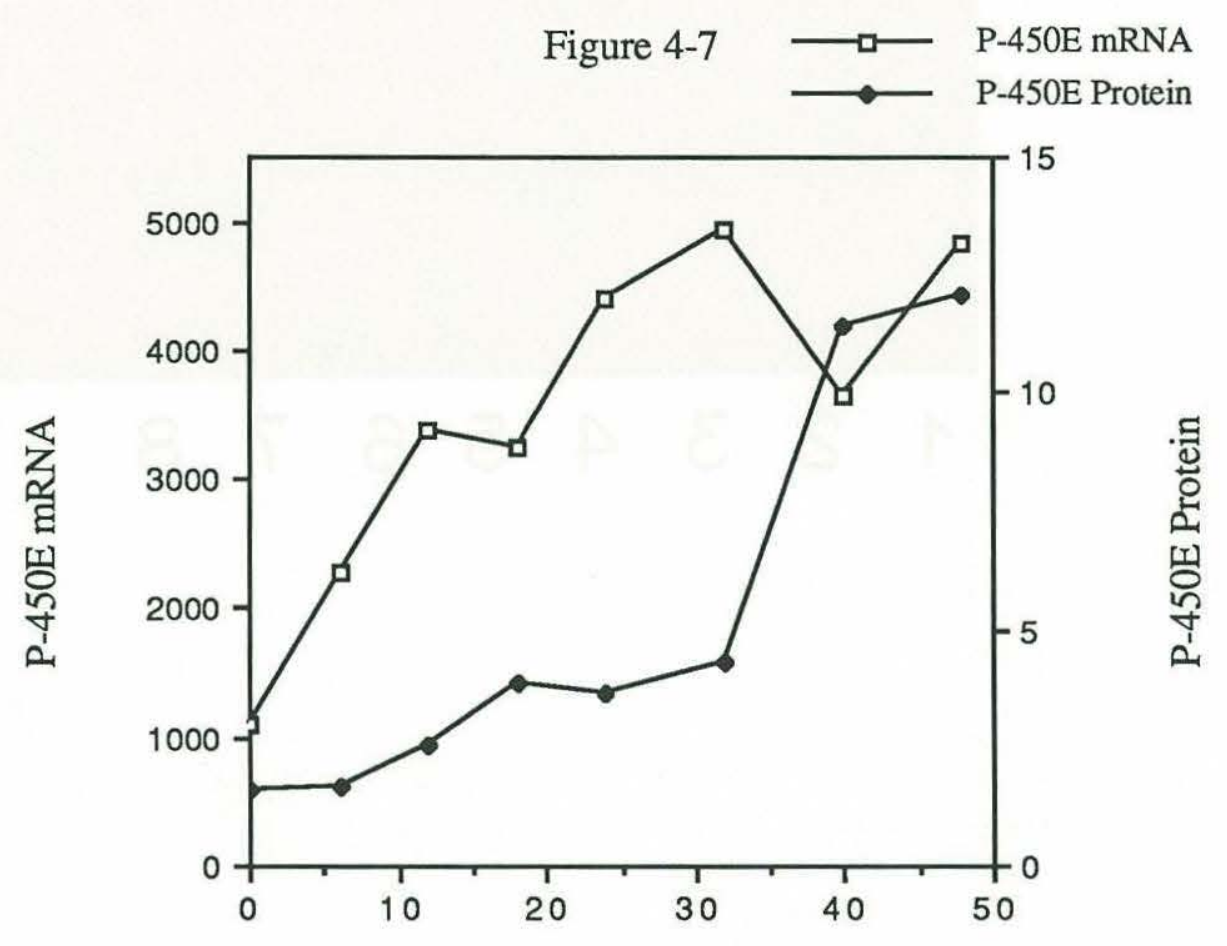

Hours after Treatment

FIGURE 4-7: Temporal relationship between Fundulus P-450E mRNA and protein levels following BNF treatment

P-450E mRNA (open squares) values are derived from densitometric scans of the Northern blot shown in Figure 4-6. P-450E protein levels (closed diamonds, as shown in Figure 4-4) are relative to spectral P-450. 
dramatically within 5 days and remained above control levels 13 days following treatment (data not shown). P-450E protein levels exhibited the same trend (Figure 4-8A). P-450E mRNA was measured by both in vitro translation/immunoprecipitation (Figure 4-8A) and Northern blot analysis (Figure 4-8B). P-450E mRNA peaked at the one-day time point and declined rapidly, with no (Figure 4-8A) or little (Figure 4-8B) signal at 8 and 13 days following BNF treatment. Therefore, mRNA accumulation or stability over extended times does not occur and cannot account for the long-term presence of $\mathrm{P}-450 \mathrm{E}$ protein and EROD activity.

The Fundulus treated for this 13 day experiment were held over winter and injected with BNF in early May. Although their GSI values were higher than those of immature animals used in earlier experiments, they achieved the same levels of EROD activity and P-450E protein levels as their immature counterparts. The issue of inducibility of mature vs immature teleosts is addressed in more detail in Chapter 5, as animals used for the dual label experiment were treated at the same time, and sufficient fish were analyzed for MFO parameters for statistical analysis.

\section{DISCUSSION}

As discussed in Chapter 3, the physical and functional similarities between $\mathrm{P}-450 \mathrm{E}$ and its mammalian orthologues suggested that the regulation of P-450E might resemble that of the better-studied mammalian forms. Chapter 3 established the time course of protein induction and the experiments outlined here address the question of transcriptional enhancement in lower vertebrates. Using specific antiP-450E antibodies and the trout P450IA1 cDNA probe (Heilmann et al., 88), I have found evidence that transcriptional enhancement is a possible induction mechanism in fish. My results led me to examine later time points in the 
FIGURE 4-8: Decline in P-450E mRNA levels

P-450E mRNA levels were measured by in vitro translation and immunoprecipitation or by Northern hybridization with a [32P]-cDNA, as described in the Materials and Methods sections in Chapter 3 and this Chapter.

A : P-450E mRNA was determined as in Figure 4-5. Means are shown (open squares). P-450E protein was measured by immunoblotting with MAb 1-12-3 (means: closed diamonds).

B: P-450E mRNA was determined by hybridization of fractionated total RNA with the cDNA pfP $1450-3$ '. Means are shown (open circles). 

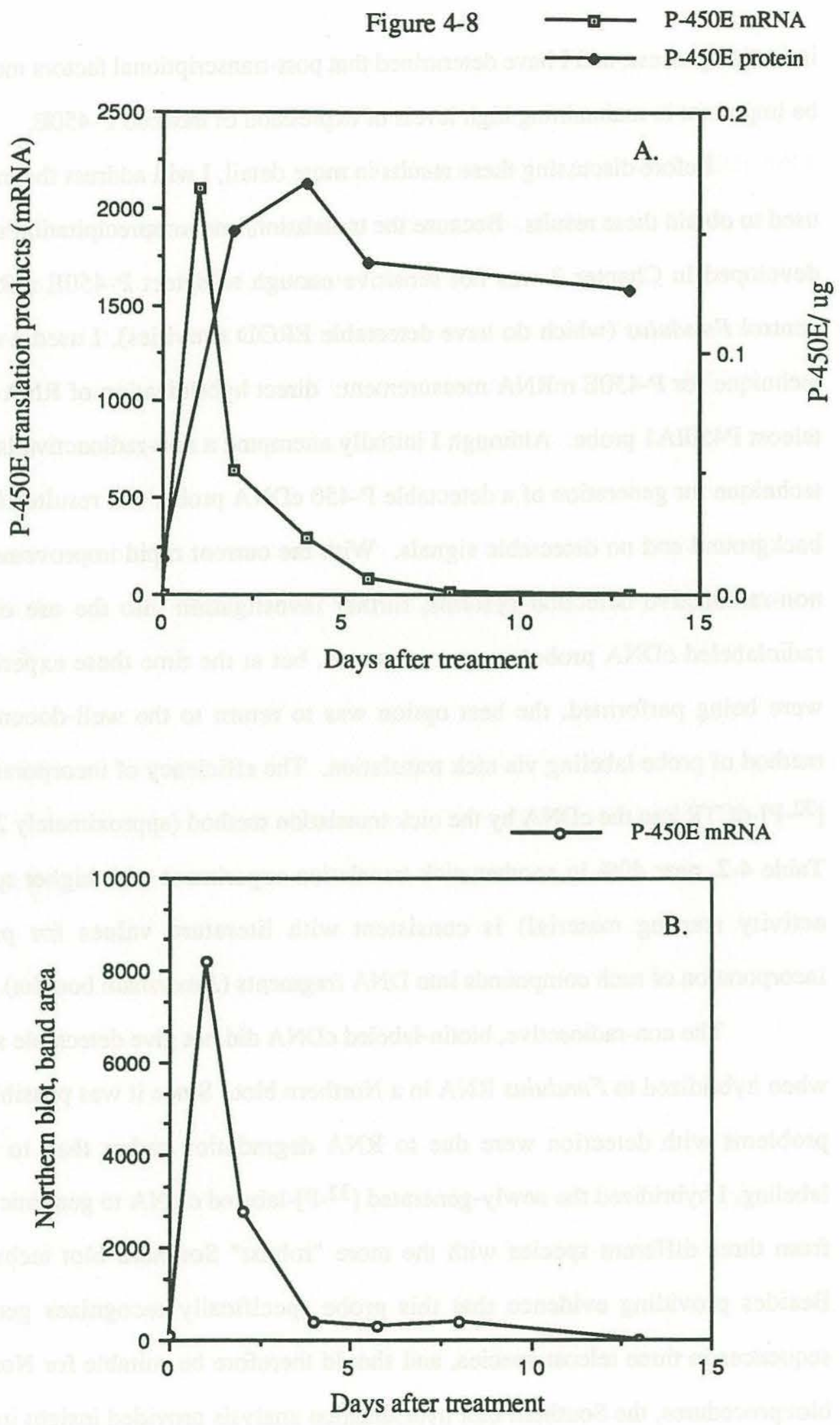

135 
induction process, and I have determined that post-transcriptional factors must also be important in maintaining high levels of expression of induced P-450E.

Before discussing these results in more detail, I will address the methods used to obtain these results. Because the translation/immunoprecipitation method developed in Chapter 3 was not sensitive enough to detect P-450E mRNA in control Fundulus (which do have detectable EROD activities), I used a second technique for P-450E mRNA measurement: direct hybridization of RNA with a teleost P450IA1 probe. Although I initially attempted a non-radioactive labeling technique for generation of a detectable P-450 cDNA probe, this resulted in high background and no detectable signals. With the current rapid improvements in non-radioactive detection systems, further investigation into the use of nonradiolabeled cDNA probes seems warranted, but at the time these experiments were being performed, the best option was to return to the well-documented method of probe labeling via nick translation. The efficiency of incorporation of [32-P]-dCTP into the cDNA by the nick translation method (approximately $21 \%$ in Table 4-2, near $40 \%$ in another nick translation experiment with higher specific activity starting material) is consistent with literature values for percent incorporation of such compounds into DNA fragments (Amersham booklet).

The non-radioactive, biotin-labeled cDNA did not give detectable signals when hybridized to Fundulus RNA in a Northern blot. Since it was possible that problems with detection were due to RNA degradation rather than to probe labeling, I hybridized the newly-generated [32-P]-labeled cDNA to genomic DNA from three different species with the more "robust" Southern blot technique. Besides providing evidence that this probe specifically recognizes genomic sequences in three teleost species, and should therefore be suitable for Northern blot procedures, the Southern blot hybridization analysis provided insight into the 
nature of the P450IA1 gene in these species. Rainbow trout may have more than one such gene in their genome, while both scup and Fundulus appear to be limited to a single cross-reactive gene. More work needs to be done to properly address such questions.

Relationships between P-450E protein, activity, and mRNA levels were revealed by examining various time points in the induction process. The results presented in Chapter 3 from the 20 day induction experiment and here from the 48 hour experiment indicate the close relationship between P-450E protein and EROD catalytic activity. The 48 hour experiment was undertaken to examine protein and mRNA levels at the initial stages of the induction process. As expected, spectral b5 and P-450 levels did not change over the 48 hour period (Table 4-2). However, increases in both EROD activity and immunochemically detectable P-450E levels indicated that the BNF-treated animals were responsive (Figure 4-4). It was exciting to see that by the first time point examined, 6 hours after exposure to BNF, P-450E mRNA was elevated (Figure 4-5) above control levels. The samples had been balanced for TCA-precipitable counts and the relative intensity and $\mathrm{M}_{\mathrm{r}}$ of the banding patterns obtained by immunoprecipitating with a non-specific antibody was similar for all time points assayed (data not shown). Thus, the proportion and types of other translatable mRNA present in the total RNA remained constant. Hybridization of the trout $\mathrm{P}_{1} 450 \mathrm{cDNA}$ probe to a Northern blot containing size-separated RNA from Fundulus at 0 and 48 hours after treatment confirmed the trend of the in vitro translations (Figure 4-6). Therefore, we conclude from both in vitro translation analysis and direct hybridization that P-450E mRNA is elevated in BNF-treated animals by 6 hours after treatment. 
Recent reports indicate that post-transcriptional control may be important in the accumulation of P450IA mRNAs. Rat P-450d (P450IA2) mRNA can accumulate in primary hepatocyte cultures following TCDD treatment, with no changes in transcription rate (Pasco et al, 88). A similar study of rat hepatocyte cultures presented evidence for post-transcriptional control in MC-induction of both P-450c and P-450d, although transcriptional control could account for P-450c mRNA increases in vivo (Silver \& Krauter, 88). Nebert and coworkers found inconsistencies between mouse $\mathrm{P}_{1} 450$ and $\mathrm{P}_{3} 450$ transcriptional rates and mRNA levels in a number of extrahepatic tissues (Kimura et al., 86). To confirm that the accumulation of Fundulus $\mathrm{P}-450 \mathrm{E}$ mRNA I have observed is due to de novo synthesis rather than mRNA stabilization, transcriptional rates should be measured in isolated nuclei. The data presented are consistent with a mechanism based at least partially on transcriptional enhancement having an important role in the induction of the major MC-inducible form of P-450 in teleosts.

$\mathrm{P}-450 \mathrm{E}-$ specific mRNA levels rise in advance of increases in P-450E protein or activity (Figure 4-7). A lag between mRNA and protein accumulation is consistent with studies of induction in mammalian P-450 systems. It is difficult to measure the lag between initial mRNA and protein or activity increases observed in Fundulus, but it appears to be about 26 hours. While it is possible that the sensitivity limits of the analyses employed or variability within the control groups may be obscuring the earliest rises in P-450E protein content or activity, it is probable that this lag is real. The lag is more pronounced than that seen in mammals, which could be due to temperature effects, physiological differences in protein synthesis, or other factors. In any case, the results are fully consistent with a receptor-mediated mechanism in fish. This is contrary to the suggestion made by Denison et al. (85) that some other, non-receptor-mediated mechanism 
might explain the long period of 4 to 7 days before maximal monooxygenase activity is reached in fish.

While P-450E mRNA levels appeared to peak or plateau within 2 days after BNF treatment (Figure 4-5), immunodetectable P-450E protein continued to accumulate for about 7 days (Figure 3-1). Thus, I carried out an additional study of P-450E mRNA and protein content at times following establishment of the induction response. Because P-450E mRNA levels were not examined beyond 48 hours in the first RNA experiment, it could not be ruled out that the mRNA had been stabilized beyond 48 hours (or, more unlikely, exhibited a second peak in content) and was maintained at some sufficiently high level to act as a template for new P-450E protein synthesis. The results (Figure 4-8) showed that the maintenance of $\mathrm{P}-450 \mathrm{E}$ protein levels through at least 13 days was not due to a second peak in mRNA levels or to stabilization of a moderate level of mRNA. The P-450E mRNA levels declined rapidly, with no evidence of a secondary spike. Therefore, transcription may be the rate-limiting component early in P-450E induction, with other factors playing a dominant role in maintaining the protein. Mammals can show endogenous P450IA1 activity despite undetectable or nonfunctional $A h$ receptors (e.g., differentiated F9 cells, cited by Kimura et al., 87), and perhaps P-450E in lower vertebrates, including fish, is regulated through another, as yet undefined mechanism.

The persistence of the teleost P-450E catalyst is in contrast to the quick return to control levels achieved by mammalian $\mathrm{PAH}$-inducible proteins. As this persistence cannot be explained by an unusually long-lived P-450E mRNA, it seemed important to examine the turnover of teleost microsomal proteins and P-450E. This aspect is explored in Chapter 5. 


\section{FOOTNOTES}

1 Interestingly, when scup total RNA was electrophoresed on formaldehyde/ agarose gels next to samples of rat or chick RNA and stained with ethidium bromide, the fish large rRNA migrated farther on an agarose gel than did the corresponding chick or rat $28 \mathrm{~S}$ rRNA, indicating that the fish rRNA may have a smaller size. In their investigations of diploidization, Leipoldt and coworkers electrophoresed RNA from a variety of species under denaturing conditions on 2.5 to $3.0 \%$ polyacrylamide gels (Leipoldt et al., 84). Although the authors do not explicitly address this result in the text of the article, some fish species such as Barbus tetrazona, Leuciscus cephalus, and others appeared to have lower molecular weight "28S" rRNA bands, compared to mouse cytoplasmic RNA size markers. I did not electrophorese Fundulus RNA simultaneously with other RNAs, but future studies should investigate the relative sizes of teleost and mammalian rRNAs, to determine whether this observation holds true for scup only, or for other marine teleosts as well. 
CHAPTER 5:

PROTEIN AND HEME TURNOVER STUDIES IN

FUNDULUS HETEROCLITUS

Page

$\begin{array}{ll}\text { INTRODUCTION } & 142\end{array}$

General Protein Turnover $\quad 142$

General Heme Turnover 146

$\begin{array}{ll}\text { Protein Turnover in Fish } & 147\end{array}$

$\begin{array}{lr}\text { Heme Turnover in Fish } & 150\end{array}$

$\begin{array}{ll}\text { MATERIALS AND METHODS } & 153\end{array}$

General Methods 153

Antibody Production \& Immunoprecipitation of Microsomal $\begin{array}{ll}\text { P-450E } & 153\end{array}$

Experiment 1: Animal Treatment \& Preparation of Microsomes 155

Experiment 1: Sample Counting and dpm Calculations 156

Experiment 2: Dual Label Materials and Treatment 157

$\begin{array}{ll}\text { Statistics } & 159\end{array}$

$\begin{array}{lr}\text { RESULTS } & 159\end{array}$

Immunoprecipitation of Microsomal P-450E - Early Attempts 159

Experiment 1: Basic Parameters \& [ $\left.{ }^{3} \mathrm{H}\right]$-Leucine Incorporation 162

Experiment 1: Immunoprecipitation 165

Experiment 2: Basic Parameters 168

Experiment 2: Incorporation of $\left[{ }^{3} \mathrm{H}\right]$ and $\left[{ }^{14} \mathrm{C}\right] \quad 170$

$\begin{array}{ll}\text { DISCUSSION } & 177\end{array}$ 


\section{INTRODUCTION}

I had two major reasons for embarking on a study of the turnover of P-450E apoprotein and heme in induced Fundulus heteroclitus. First, very little is known about protein turnover or hepatic heme metabolism in fish. Thus, basic knowledge of the kinetics and mechanisms of turnover could be gained from these studies. Second and more specifically, I was interested in the time course of increase and decrease in expression of P-450E following induction, and how it might compare to similar expression in mammals. The results reported in Chapter 4 suggest that while P-450E mRNA levels decline rapidly following exposure to a chemical inducer, $\mathrm{P}-450 \mathrm{E}$ protein (and catalytic activity) levels remain elevated over much longer periods of time (e.g., Figure 4-8). One possible reason for this would be a long P-450E half-life, or slow turnover. Thus, the experiments described in this Chapter were designed 1) to establish some baseline data on the uptake and incorporation of labeled amino acid and aminolevulinic acid in teleosts, and provide radiolabeled material for testing immunoprecipitation procedures, and 2) to begin to address questions of both $\mathrm{P}-450 \mathrm{E}$ apoprotein and heme turnover in fish via a dual label experiment.

\section{General Protein Turnover}

The theories concerning protein synthesis and degradation have been detailed by several authors. The following discussion, which outlines some of the major problems and ideas behind various methods, is based on articles by Zak et al., 79; Berlin and Schimke, 65; Arias et al., 69; and Gan and Jeffay, 67. The rate of protein synthesis is considered to be zero order (not dependent on protein concentration), while degradation is seen as a first order reaction (dependent on the current protein concentration). 
In general, real proteins do exhibit first order decay kinetics. Blood hemoglobin is an exception: it degrades rapidly when red blood cells are degraded and thus shows "life span" kinetics. In turnover experiments using radiolabeled precursors, the rate of change of a protein's radioactivity is proportional to the difference between the specific radioactivity of the precursor (amino acid) and of the product (protein). However, the specific activity of the amino acyl tRNA pool may not equal that of the intracellular free amino acid pool or the plasma free amino acid pool. In fact, there may two or more discrete pools of available charged tRNAs, each with a unique specific radioactivity. Thus, unless amino acyl tRNAs are measured, it is not possible to know precursor concentrations. The theoretically most straight-forward analysis should measure the specific activity of the incorporated label and of the actual precursor population. This is not a simple operation, and much effort has gone in to devising new labeling conditions and techniques.

An additional problem must also be addressed. The simple assumption that decay of radiolabel in a protein corresponds to the protein's half-live is almost always an overestimate of the half-life, because radiolabeled tracers are not eliminated instantaneously from the body, but may be reutilized. The more likely the reuse of the precursor, the greater the overestimate. Various methods have been developed the circumvent this problem. The use of $\left[{ }^{14} \mathrm{C}\right]$-guanidino-arginine decreases the extent of reutilization of label, as high levels of arginase in the mammalian liver will convert the labeled guanidino carbon to a portion of the readily-excreted urea molecule (see discussion of Arias et al., 69, below). A more recent improvement, which avoids the incorporation of extrahepatic arginine (e.g., mobilization of reutilized label from tissues lacking high levels of arginase), is the injection of $\left[{ }^{14} \mathrm{C}\right]$-bicarbonate. In hepatocytes, bicarbonate is incorporated directly 
into the urea cycle by carbamoyl phosphate synthase and incorporated into protein as arginine (and other amino acids such as aspartate). The label will again end up in urea, rather than being reutilized. Arias et al. (69) employed these methods to address the question of whether endoplasmic reticulum (ER) proteins degrade simultaneously (the "unit membrane" hypothesis) or independently (the "mosaic" model). When they injected $\left[{ }^{14} \mathrm{C}\right]$-guanidino-arginine rather than normal $\left[{ }^{14} \mathrm{C}\right]-$ arginine, they found that the "mean half-life" of proteins in each subcellular compartment was decreased (e.g., SER 2.1 vs 5.2 days, RER 2.0 vs. 5.8 days, total microsomes 3.0 vs. 5.2 days).

Arias et al. (69) also developed a dual label technique for the determination of whether there existed different rates of protein degradation in a given set of proteins. This involved injection with a radiolabeled compound (e.g., $\left[{ }^{14} \mathrm{C}\right]$-leucine) at the beginning of the experiment, followed by injection shortly before termination of the experiment with the same compound labeled with a different isotope (e.g., $\left[{ }^{3} \mathrm{H}\right]$-leucine). (The theory behind this technique, which bypasses the need for knowledge of precursor specific activity, is detailed by Zak et al., 79). By this analysis, cytochrome $\mathrm{b}_{5}$, NADPH-cytochrome $\mathrm{c}$ reductase, and other microsomal protein fractions had very different half-lives, supporting the view that the ER is comprised of proteins with different rates of synthesis and degradation. Treatment with phenobarbital (PB) stimulated the synthesis of some ER proteins but not others, and did not appear to influence degradation rates of bulk proteins. Based on these results, Arias et al. (69) concluded that the findings by other researchers of protein stabilization (reduction in degradation) following PB treatment may be attributable to an increase in reutilization due to an increase in synthesis. 
In a direct application of the technique developed by Arias et al. (69) to the study of P-450 isozymes, Voorman and Aust (88) injected TCDD pre-treated rats with $[3 \mathrm{H}]$-leucine three hours prior to addition of a second inducer (isosafrole or $3,4,5,3^{\prime}, 4^{\prime}, 5^{\prime}$-hexachlorobiphenyl) and injected $\left[{ }^{14} \mathrm{C}\right]$-leucine shortly before termination of the experiment. The greater retention of ${ }^{3} \mathrm{H}$ relative to ${ }^{14} \mathrm{C}$ in immunoprecipitated P-450d from isosafrole- and HCB-treated animals $\left({ }^{3} \mathrm{H} /{ }^{14} \mathrm{C} \sim\right.$ 2.6 and 2.7) compared to retention in animals not exposed to a second inducer $\left({ }^{3} \mathrm{H} /{ }^{14} \mathrm{C} \sim 1.5\right)$ led the authors to conclude that the increase in P-450d half-life resulting from treatment with these inducers (also observed in previous studies) is due to decreased degradation of P-450d. The formation of an isosafrole/P-450d complex may be the basis of the stabilization mechanism.

Parkinson et al. (83a) find fault with the application of Arias et al.'s (69) dual label technique, because it is usually taken as an endpoint determination, giving no information on the shape of the radioactive decay curve. They point out that this is a problem particularly when highly reutilizable amino acids, such as leucine, are used. These researchers turned instead to bicarbonate as a nonrecycleable precursor. Parkinson et al. (83a) examined the change in radiolabel in Aroclor 1254-treated rats during a period of prolonged induced steady-state levels of each P-450 isozyme. Turnover was determined by measuring isotope decay $\left(t_{1 / 2}\right.$ was estimated from the slope of a straight line fitted by linear regression analysis to a semilog plot of specific radioactivity vs time).

For each P-450 isozyme, turnover of the heme moiety was significantly more rapid than that of the apoprotein moiety in Parkinson et al.'s (83a) work. Both P-450 $(\mathrm{b}+\mathrm{e})(\mathrm{P} 450 \mathrm{IIB}(1+2))$ and P-450c had heme half-lives of about 28 to 29 hours, compared to an apoprotein half-life of 37 to 38 hours $(P<0.01)$. All the P-450 apoproteins examined exhibited shorter half-lives than did the "average" 
hepatic microsomal protein (total microsomal protein showed biphasic kinetics, with a rapid phase of 5-8 hr and a slow phase of $82 \mathrm{hr}$ ). The authors also compared these half-life calculations (based on isotopic decay determinations) with half-lives calculated from the time it takes for an induced protein to reach one half its new steady state level (Berlin and Schimke, 65) ${ }^{1}$. The latter values were obtained from a time course study of Aroclor induction of the corresponding isozymes (Parkinson et al., 83b). Values calculated for both methods showed close agreement for P-450 b + e ( $37 \mathrm{hr}$ by kinetics, $38 \mathrm{hr}$ by isotope decay), P-450c (37 hr for both), and epoxide hydrolase (121 and $132 \mathrm{hrs}$, respectively).

\section{General Heme Turnover}

As discussed in Chapter 1, heme may be intimately involved in the regulation of P-450 expression. Contradictory results have been obtained concerning relative rates of $\mathrm{P}-450$ heme turnover and apoprotein turnover. While Parkinson et al. (83a) found that the heme moiety has a shorter half-life compared to the rat P-450c apoprotein, Sadano and Omura (82) found that heme has the same half-life as the MC-P-450 apoprotein (both $15 \mathrm{hr}$ in PB-induced rats) and shorter than the PB-P-450 apoprotein (heme at $15 \mathrm{hr}$, apoprotein at 25 to $30 \mathrm{hr}$ ). These differences may be due to induction regimes or labeling protocols. Sadano and Omura (82) found that the heme moieties incorporated in P-450 isozymes have more rapid turnover than do the heme components of other cellular proteins.

In contrast to the problems caused by possible amino acid reutilization in the synthesis of proteins, the heme precursor ALA provides a good label. ALA is a specific substrate for ALA synthase in the hepatic heme biosynthetic pathway, and during degradation heme is converted to bilirubin and the porphyrin ring is not reutilized. Druyan et al. (69) found insignificant incorporation of ALA into nonheme proteins in the rat liver. The turnover of microsomal cytochrome $b_{5}$ was 
determined by counting radioactivity in purified $b_{5}$ isolated from microsomes of rats up to 17 days after treatment. Turnover determined by $\left[{ }^{3} \mathrm{H}\right]$-ALA counts was 2.4 days, while it was 2.5 days according to labeling with $\left[{ }^{14} \mathrm{C}\right]$-guanidinoarginine. Thus, turnover of heme and protein may be coincident in at least a subpopulation of microsomal proteins. Of course, if reports of heme shifting between different P-450 molecules are correct (e.g., Sadano and Omura, 83), this would add a complicating factor.

\section{Protein Turnover in Fish}

A literature search of "fish," "protein turnover," and "heme" revealed that very little work has been published in these areas. Most protein studies have emphasized turnover of total protein in muscle, or compared muscle protein synthesis to that in other tissues in the body. The following discussion briefly describes some of the techniques used and the results obtained from some of these fish studies; note that in general total radioactive counts, or at most acid-soluble vs. acid-insoluble counts, were measured. Only in the last papers mentioned (Vodnicik et al., 84; Sadler et al., 85) is any fractionation beyond the tissue level attempted.

Various methods have been used to address protein turnover in fish. There is surprisingly little or no concern expressed in the publications regarding possible amino acid reutilization or other problems. The question of precursor measurement has also not been satisfactorily answered. It is very difficult to determine the content of the actual protein precursor, which is the appropriately charged amino acyl tRNA. Some researchers measure the extracellular and the intracellular amino acid content, and estimate that the actual content should fall between these values (e.g., Fauconneau and Arnal, $85 a$ and 85 b). In an attempt to quantify teleost amino acid metabolism (oxidative metabolism vs protein 
synthesis), Fauconneau and Arnal (85b) gave rainbow trout a single injection of $\left[{ }^{14} \mathrm{C}\right]$-leucine to the caudal vein and measured $\left[{ }^{14}\right]-\mathrm{CO}_{2}$ excreted in a respiratory chamber. The trend of leucine incorporation (lowest in the muscle and higher in the liver and digestive tract) is the same as that observed in mammals, but the quantitative differences were not as great as those in mammals. Whole fish protein synthesis was lower than that in mammals. Approximately $60 \%$ of leucine metabolized in whole fish was directed toward protein synthesis, while $36-37 \%$ of the leucine was catabolized.

L-leucine is taken up in fish by a combination of facilitated diffusion and active transport (reference in Persell and Haschemeyer, 80). Persell and Haschemeyer examined initial in vivo amino acid uptake in the liver of the toadfish Opsanus tau. These researchers used inulin as a marker of the extracellular space for standardization of the leucine counts. They found that amino acid transport and protein synthesis were both strongly temperature dependent, slowing down at lower temperatures.

Haschemeyer and coworkers (Pocrnjic et al., 83) employed phenylalanine swamping in further studies of toadfish protein turnover to provide a constant source of radiolabeled precursor. In mammalian studies, this method is useful for measuring rates of protein synthesis in tissues having very rapid protein turnover (Garlick et al., 80). Phenylalanine is preferred over leucine because large quantities of the latter have been shown to play a role in the control of muscle protein synthesis and breakdown. High rates of protein turnover were observed in the head kidney, gill, and spleen, as well as the liver. There was a large effect of temperature on phenylalanine incorporation into protein, with a $\mathrm{Q}_{10}$ of 6 to 7 . Pocrnjic et al. (83) speculated that the drop in protein synthesis with lower temperatures may be due to temperature effects on the elongation rate of the 
growing polypeptide and/or on ribosome recruitment. Unfortunately, the final time point in these studies is a mere 10 minutes after injection of the amino acid (while decline is still linear), limiting their usefulness to investigations of the most rapidly changing proteins.

A few studies have addressed, at least peripherally, turnover of P-450 proteins in fish. Vodnicik et al. (84) examined the incorporation of $\left[{ }^{35} \mathrm{~S}\right]-$ methionine into trout microsomal proteins. Trout were induced with $150 \mathrm{mg} / \mathrm{kg}$ BNF, injected with the radiolabel 18 hours later, and sacrificed at various times following the addition of the label. The pattern of label incorporated into proteins in the total microsomal fraction was compared to that for untreated animals. Mean incorporation was higher in BNF-treated animals, but was not significantly different from incorporation in control animals. Three bands, of $\mathrm{M}_{\mathrm{r}} 59,000$, 57,000 , and 50,000, appeared in autoradiograms of SDS PAGE gels of BNFtreated trout microsomes. Trout $\mathrm{P}_{1} 450$ has a $\mathrm{M}_{\mathrm{r}}$ of near 58,000 (Williams and Buhler, 84). It was not established which, if any, of these proteins contained heme, and their identity was not further investigated. Thus, this study provides circumstantial evidence of de novo $\mathrm{P}-450$ protein synthesis in induced animals.

I decided to attempt a Fundulus dual label experiment patterned after the method described by Parkinson et al. (83a), as the fish papers I found did not address label incorporation into specific proteins. In addition, many of the fish methods involved restraining the animals during the course of the experiment (not feasible for treatment and long-term maintenance of some 40 to 60 individual Fundulus), or labeling for a very short time interval. Although Parkinson et al. (83a) were investigating mammalian P-450 turnover, the inducer used - Aroclor 1254 - caused a prolonged P-450 protein induction response, on a similar temporal scale to the effects I observed with BNF treatment of Fundulus (Chapter 3). I 
could not replicate the protocol exactly, however. The use of $\left[{ }^{14} \mathrm{C}\right]$-bicarbonate in mammals is based on the rapid elimination of label due to high levels of arginase, as described above. In teleosts, nitrogen is excreted primarily as ammonia through the gills (Forster and Goldstein, 69). The small amount of urea excreted by teleosts is derived primarily from nucleotides via the uricolytic pathway, and although most teleosts probably have a complete set of ornithine-urea cycle enzymes, the activity of the rate limiting enzyme carbamoyl phosphate synthase is usually very low (van Waarde, 83). Given these physiological differences, I decided to return to the "simple" methods and inject the radiolabeled amino acid (leucine) itself, rather than a pre-amino acid precursor. Although ALA appears to be a very specific label of mammalian heme, with little or no reutilization into other compounds, there exists no baseline knowledge of its uptake and degradation pathways in fish. All results must be considered with the possible reutilization of labeled leucine (and less likely, of ALA) in mind, as reutilization of hepatic leucine or uptake of extrahepatic leucine may complicate the interpretations of these studies.

\section{Heme Turnover in Fish}

Little is known about heme metabolism in teleosts. Fernandez et al. (87) sought ALAS (ALA synthase, the rate limiting enzyme of mammalian hepatic heme synthesis) activity in rainbow trout tissue. They found evidence for two forms, a 110,000 dalton cytosolic form and a 70,000 dalton (possibly inner membrane) mitochondrial form. It is not clear from their descriptions whether the cytosolic form is active in vivo, or is simply an immature precursor awaiting transport to the mitochondria. In fact, May et al. (86) state that the question of whether a cytosolic form of ALAS is active or not is a moot point, since the substrate succinyl-CoA is not present in the cytosol. Gooch and Matsumura (83) 
measured ALAS in goldfish (Carassius auratus) whole liver homogenates. There was no significant difference between control and BNF-treated activities: both were near $10 \mathrm{nmol}$ product/g liver/hr. Analysis of ALA synthase activity in scup homogenates (Dr. Neal Cornell (NIAAA and WHOI), unpublished observations) gave the following results: 2 individuals had activities of 6.0 and $9.5 \mathrm{nmol} / \mathrm{g}$ liver $/ \mathrm{hr}(0.071$ and $0.106 \mathrm{nmol} / \mathrm{mg}$ protein/ $/ \mathrm{hr})$, values similar to the Gooch and Matsumura (83) findings. The ALAS activity for liver homogenate from a starved (e.g., partially induced) rat - measured by Dr. Cornell simultaneously with the scup samples - was $36 \mathrm{nmol} / \mathrm{g}$ liver $/ \mathrm{hr}$.

Preliminary results from this laboratory indicate that scup liver homogenates have the capacity to incorporate ALA into heme and protoporphyrin (Dr. Mark E. Hahn, unpublished observations). The rate of ALA incorporation in scup liver homogenates is approximately one-third of the rate measured simultaneously in rat homogenates (13.9 vs $44.2 \mathrm{nmol}$ ALA equivalents/g liver/hr at $30^{\circ} \mathrm{C}$ ). Thus, it appears from these preliminary studies that the production of ALA (rate of ALAS activity) is slower than all other enzymatic steps of scup hepatic heme biosynthesis (rate of incorporation of ALA by a multi-step process into heme). This is consistent with the mammalian literature, which indicates that ALAS is the rate-limiting enzyme in hepatic heme biosynthesis.

Heme oxygenase is the rate limiting enzyme of heme degradation in mammals (heme is metabolized to biliverdin). An additional enzyme, biliverdin reductase, converts mammalian biliverdin to bilirubin, which is then conjugated and excreted. Reptiles and birds excrete biliverdin and fish appear to belong to two categories, with the excretion of bilirubin and/or biliverdin possible. In a survey of bile from numerous fish species (Fang, 87), yellow bile generally contained conjugated bilirubin, while green or yellow-green bile contained 
unconjugated biliverdin and occasionally some bilirubin. Teleosts challenged with excess biliverdin did not convert it to bilirubin, as mammals can (Fang, 87); starvation increased the ratio of biliverdin to bilirubin. These results indicate that biliverdin reductase in fish may be limiting under some conditions, leading to biliverdin excretion. M. Maines and J.J. Stegeman (unpublished observations) found very low levels of biliverdin reductase in scup hepatic cytosols (20-30 fold lower than in rats), while microsomal heme oxygenase was also low (but only about 10 fold lower than in rats). The possible effects of P-450 inducers on these activities in teleosts is not known.

In an experiment which measured incorporation of label into the heme moiety of microsomal proteins, $\left[{ }^{14} \mathrm{C}\right]$-ALA was injected i.p. into rainbow trout held at $6^{\circ} \mathrm{C}$ at an unspecified time ("after....suitable time for induction") after treatment with Aroclor 1254 (60 mg/fish, fish 300-800 g, Sadler et al., 85). Peak $\left[{ }^{14} \mathrm{C}\right]$ incorporation (as dpm/mg microsomal protein) was observed at 20 to 25 hours after injection. The induced animals exhibited a temporal trend in labeling parallel to that of control animals (given ALA only). Although no difference is discussed in the text, the mean $\mathrm{dpm} / \mathrm{mg}$ from Aroclor-treated animals was close to the mean dpm/mg value for control animals only at early time points. By 24 hours, the Aroclor mean was lower and it maintained a parallel, lower value through 96 hours. Sadler et al. (85) compare their results to a rat study where peak ALA incorporation occurred 2 hours after i.v. administration. They note that while ALA is incorporated in rats predominantly into hepatic heme proteins, in the trout ALA was incorporated predominantly in the kidney, the site of fish erythropoiesis. Given this fact, and the different routes of administration, direct comparisons cannot be readily made. 


\section{MATERIALS AND METHODS}

\section{General Methods}

Materials were obtained from the sources listed in Chapters 3 and 4, or from individual suppliers as noted below. Animal collection and care, preparation of and injection with BNF solutions, and preparation of hepatic microsomes were all carried out as described in Chapter 3, with the modifications described below. Protein determinations, spectral $b_{5}$ and P-450 specific content measurements, and EROD assays were performed as described in Chapters 2 and 3.

The immunoblot procedure described in Chapter 2 was modified by the addition of another step. After electrophoretic transfer of proteins to a nitrocellulose filter, the filter was reversibly stained for 5 minutes with Ponceau S (working solution: $0.2 \%(w / v)$ Ponceau S/ 3.0\% (w/v) TCA/ 3.0\% (w/v) sulfosalicylic acid). The filter was rinsed with water, pink/reddish protein bands were visualized, and the nitrocellulose was placed in PBS/milk blocking solution and the normal procedure continued. Previous use of Ponceau S under these conditions indicated that it caused no interference with subsequent signal development (B.R. Woodin, unpublished observations).

\section{Antibody Production and Immunoprecipitation of Microsomal P-450E}

A greater quantity of anti-P-450E polyclonal antibody was needed to establish conditions for immunoprecipitation of P-450E from relatively large microsomal samples, and an antibody preparation with reduced recognition of other microsomal proteins was desired. Thus, I prepared additional polyclonal antibody from the remaining serum from rabbit 119 as outlined in Chapter 2 (ammonium sulfate precipitation, dialysis, chromatography on a DE-52 anionic exchange column, and ultrafiltration of the first $280 \mathrm{~nm}$ peak). Approximately 440 $\mathrm{mg}$ of IgG was isolated by this procedure. This new antibody preparation was 
examined for P-450E specificity and cross-reactivity by immunoblotting purified scup P-450E and control and BNF-treated Fundulus microsomes against several antibodies. The new antibody recognized scup P-450E and a dominant single band (the P-450E orthologue) in the Fundulus microsomes. Although it also recognized a few other Fundulus microsomal proteins, these bands were much less intense relative to the $\mathrm{P}-450 \mathrm{E}$ orthologue than were other non-P-450E proteins recognized by the other polyclonal preparations. As with the other antibodies, the staining of these non-specific proteins was identical in the control and induced microsomes. This new polyclonal antibody preparation was chosen for use in the immunoprecipitation of microsomal P-450E.

Hepatic microsomal P-450E was precipitated for determination of radioactive counts, to obtain data on the specific activity of the protein itself. The development of several possible immunoprecipitation techniques is described in the Results section below. The final method used is a modification of the method described in Chapter 3 for precipitation of P-450E RNA translation products (from Fagan et al., 83). The modification included a microsomal solubilization step prior to addition of the primary PAb. Potassium cholate $(0.5 \%)$ and Emulgen 911 ( $0.2 \%$ ) were added to $0.9 \mathrm{nmol}$ spectral P-450 and the mixture was incubated on ice for 45 minutes prior to dilution by addition of immunoprecipitation buffer to 1.4 - $1.6 \mathrm{ml}$. Anti-P-450E PAb was added at $5 \mathrm{ug} / \mathrm{pmol} \mathrm{P-450} \mathrm{and} \mathrm{scup} \mathrm{P-450E}$ (as carrier) was added to $0.056 \mathrm{ug}$. $200 \mathrm{ul}(10 \%$ (w/v)) immunoprecipitin was added to each tube. All incubations on ice were of 45 minutes duration, and centrifugation after washes was for 5 minutes at $5000 \mathrm{rpm}$ in a Sorvall RC2-B high speed centrifuge (SS34 rotor head). Washed pellets were resuspended in SDS PAGE sample treatment buffer and boiled to release the antibody-antigen complexes from the immunoprecipitin. After immunoprecipitin was spun down, 
supernates were either applied directly to SDS PAGE gel electrophoresis, or added to $6 \mathrm{ml}$ Scintiverse II and analyzed for radioactive counts. To determine whether the presence of sample treatment buffer would affect dpm calculations of tritiated samples, I added different volumes of sample treatment buffer ( 0 to $150 \mathrm{ul}$ ) to solutions spiked with $\left[{ }^{3} \mathrm{H}\right]$-toluene (NEN) and counted cpm and dpm. Although the $\mathrm{H} \#$ increased and cpm values decreased with increasing volumes of sample treatment buffer, the calculated dpm remained the same. Thus, the counting program corrects well for quench under these conditions.

\section{Experiment 1: $[3$ H]-Leucine Experiment}

\section{Animal Treatment and Preparation of Microsomes}

On Day 0, 24 Fundulus heteroclitus were given a single i.p. injection of $50 \mathrm{mg} / \mathrm{kg}$ BNF in corn oil ( $5 \mathrm{mg} / \mathrm{ml}, 100 \mathrm{ul} / 10 \mathrm{~g})$. On Day 4, fish were weighed to the nearest $0.1 \mathrm{~g}$ and the volume of tritiated leucine needed based on label concentrations and dose was calculated $(5 \mathrm{ul} / \mathrm{g}$; about $4.2 \mathrm{uCi} / \mathrm{g})$. Twenty fish were injected i.p. with L-[4,5-3 $\left.{ }^{3} \mathrm{H}\right]$-leucine (Amersham, $156 \mathrm{C} / \mathrm{mmol}$, check) in fish saline using a 25 gauge needle, and placed in a closed circulating, filtered water system. At appropriate times ( 2 and 23 hours after injection with leucine), 10 fish were sacrificed, livers weighed and pooled in homogenization buffer (150 $\mathrm{mM} \mathrm{KCl} / 50 \mathrm{mM}$ Tris- $\mathrm{Cl}, \mathrm{pH} 7.4$ to 7.5 ) on ice. In addition, the 4 remaining BNF-treated animals were sacrificed concurrently with the 2 hour (hr) leucine fish, to provide a positive (unlabeled) control. Pooled livers were brought to $3 \mathrm{ml} / \mathrm{g}$ wet weight with homogenization buffer and homogenized 8 times at high speed (1160 rpm). Bodies and ovaries were weighed later. Aliquots were taken for determination of "total" and TCA-precipitable counts of whole liver homogenates, and the remaining homogenates were used to prepare microsomes as usual. 
Microsomes, resuspended to $2 \mathrm{ml}$ per g liver, were aliquoted for "total" and "TCA" counts and stored in liquid nitrogen.

\section{Sample Counting and dpm Calculation}

Aliquots were taken from each sample as follows: a) $2 \times 75 \mathrm{ul}$ homogenate were transferred directly to a scintillation vial ("total" counts), b) $2 \mathrm{x}$ $100 \mathrm{ul} \mathrm{homogenate}$ were transferred to an Eppendorf tube for acid precipitation ("TCA" counts). Larger aliquots were initially examined, to determine if such small volumes would provide detectable and consistent measurements. The values obtained for both large and small volumes were similar, and therefore the smaller volumes were used here and in subsequent experiments.

Counts were determined according to the method described by Parkinson et al. (83). Briefly, for total counts, $12 \mathrm{ml}$ liquid scintillation cocktail was added directly to the $75 \mathrm{ul}$ aliquot and the sample was vortexed for 30 seconds and counted. For TCA counts, 400 ul cold $12.5 \%$ TCA was added to the $100 \mathrm{ul}$ aliquot. The mixture was vortexed, then left on ice until ready to proceed. At this time, the sample was centrifuged in a Sorvall high speed centrifuge for $10 \mathrm{~min}$, $0^{\circ} \mathrm{C}, 2500 \mathrm{rpm}$ (SS34 rotor). The pellet was washed twice with $1 \mathrm{ml} 10 \%$ cold TCA and twice with $1 \mathrm{ml}$ anhydrous diethyl ether. The pellet was then resuspended in $300 \mathrm{ul} 1 \mathrm{M} \mathrm{NaOH}$ and left at room temperature overnight. The sample was heated for 2 hours at $60^{\circ} \mathrm{C}$, cooled to room temperature, and neutralized. Generally, two 150 ul aliquots of each sample were neutralized with 638 ul $0.25 \mathrm{~N} \mathrm{HCl} .12 \mathrm{ml}$ ScintiVerse II was added and the sample was counted. The program designed to count $\left[{ }^{3} \mathrm{H}\right]$-leucine incorporated into RNA translation products (Chapter 3 ) was used here. 
Experiment 2: Dual Label ([ $[\underline{3} \mathrm{H}]$-leucine and $\left[{ }^{14} \mathrm{C}\right]$-ALA) Experiment Materials and Treatment

On Day 0 (May 5) fish were weighed and treated with $50 \mathrm{mg} / \mathrm{kg}$ BNF i.p. $(5 \mathrm{mg} / \mathrm{ml}, 100 \mathrm{ul} / 10 \mathrm{~g})$. On Day 4, these fish were treated with a mixture of [14-C]- delta-aminolevulinic acid (ALA, Amersham, $56 \mathrm{mCi} / \mathrm{mmol}$ ) and $\left[{ }^{3} \mathrm{H}\right]-$ leucine (Amersham, $144 \mathrm{Ci} / \mathrm{mmol}$ ). Two hundred fifty microCuries of ALA was dissolved in $200 \mathrm{ul} 0.1 \mathrm{~N} \mathrm{HCl} ; 64 \mathrm{ul}(80 \mathrm{uCi})$ of this solution was added to a total of $6 \mathrm{ml}$ fish saline containing approximately $4.9 \mathrm{mCi}\left[{ }^{3} \mathrm{H}\right]$-leucine. The remaining ALA stock was flushed with nitrogen gas and stored at $4{ }^{\circ} \mathrm{C}$ for later use. A small aliquot of the fish saline containing both $\left[{ }^{3} \mathrm{H}\right]$-leucine and $\left[{ }^{14} \mathrm{C}\right]$-ALA was taken and counted. The dpm of each isotope was calculated from this $1 \mathrm{ul}$ of stock. The tritiated leucine resulted in $1,349,999 \mathrm{dpm}$ in channel one $(0-400)$, or $74 \%$ of the expected dose. The $\left[{ }^{14} \mathrm{C}\right]$ resulted in $28,992 \mathrm{dpm}$ in channel two (400-670), or $98 \%$ of expected dose. As the leucine was taken from a vial previously used for other experiments, it is not surprising that the estimated activity was higher than the actual activity (e.g., for each previous experiment, slightly more volume than needed was removed from the vial, excess volume was wiped off the pipette, and the correct volume was used in the experiment). The $\left[{ }^{14} \mathrm{C}\right]$-ALA was obtained from a new vial, with the solid compound freshly dissolved in $\mathrm{HCl}$ and aliquoted as a known volume. Therefore, the close agreement with the estimated $\left[{ }^{14} \mathrm{C}\right]$ value indicates that these volumes were accurately measured.

Fish were weighed to the nearest $0.5 \mathrm{~g}$ and injected with $7.5 \mathrm{ul} / \mathrm{g}$ (a final dose of approximately $4.5 \mathrm{uCi} / \mathrm{g}$ leucine and $0.1 \mathrm{uCi} / \mathrm{g} \mathrm{ALA})$. The animals used in this experiment had been held over the winter and were developing "red mouth" disease, and some were not in good shape when they were injected. A few animals died immediately prior to and one died after radiolabel injection. Thus, 
there were not enough fish for three pools to be prepared at the final time point $(190 \mathrm{hr})$. In studies of the effects of feeding on the contribution of rainbow trout muscle cytosol as the source of tRNA, amino acyl tRNA synthetases, and other translation factors for protein synthesis, Junghahn and Jürss (88) found that starvation decreased the "stimulating activity" of the fish cytosols. Given this and other background information, Fundulus were fed Tetramin during the experiment. At appropriate times ( $30 \mathrm{~min}, 90 \mathrm{~min}, 8 \mathrm{hr}, 30 \mathrm{hr}, 96 \mathrm{hr}$, and $190 \mathrm{hr}$ ) after injection with the dual label, fish were sacrificed and livers were excised and weighed. Three to four livers were pooled to obtain $>1 \mathrm{~g}$ per sample, and three samples were prepared at each time point except at 190 hours, when 2 samples were prepared.

Pooled livers were brought to $4 \mathrm{ml} / \mathrm{g}$ wet weight in homogenization buffer and the procedure outlined above followed for homogenate and microsomal preparation. The final microsomal spin was for $2 \mathrm{hr}$ at $18,000 \mathrm{rpm}$ in a high speed Sorvall, rather than an ultracentrifuge, and microsomes were resuspended to 2 $\mathrm{ml} / \mathrm{g}$. Slightly smaller volumes were taken for total (70 ul) and TCA (90 ul) counts. Sample preparation was carried out as above, but a dual label dpm counting program was used to simultaneously determine $\left[{ }^{3} \mathrm{H}\right]$ and $\left[{ }^{14} \mathrm{C}\right]$ values. Both $\left[{ }^{3} \mathrm{H}\right]$ (dpm corrected for current date) and $\left[{ }^{14} \mathrm{C}\right]$ quenched standard sets (Beckman) were counted to establish quench curves for the two isotope channels. Channel 1 was defined as 0 to 400 , channel 2 as 400 to 670 . Multiple $\mathrm{H} \#$ values $(n=4)$ were calculated for each sample, and samples were counted for 20 or 30 minutes or to a 2 sigma value of $1.00 \%$. MFO parameters were measured in these samples as before. 
Statistics

Means and standard deviations were calculated and ANOVA analyses were carried out as previously described (Chapter 3 and 4). In addition, if the single factor analysis of variance showed differences between groups, the StudentNewman-Keuls test was applied to see where the differences could be found. This multiple range test was used rather than the Dunnett's test, so each group could be compared with all other groups (time points), rather than controls versus various BNF-treated groups as in previous analyses.

\section{RESULTS}

\section{Immunoprecipitation of Microsomal P-450E - Early Attempts}

Before I could proceed with a dual label experiment to address questions of P-450E apoprotein and heme turnover in Fundulus, a way of measuring radioactivity incorporated into $\mathrm{P}-450 \mathrm{E}$ had to be established. Due to the availability of anti-P-450E antibodies, I chose immunoprecipitation as the method for separating P-450E from other microsomal proteins. Several steps were taken to achieve this goal. First, microsomes were solubilized under conditions amenable to antibody-antigen interactions. Solubilization of Fundulus hepatic microsomes with potassium cholate and Emulgen 911 according to the protocol used for scup P-450E purification (Klotz et al., 83) was followed by a $21 / 2$ hour centrifugation to separate the supernates and pellets. The pellets contained less than $10 \%$ of the P-450E found in the supernate, which contained amounts consistent with the expected $\mathrm{P}-450 \mathrm{E}$ in each sample.

The next step was to establish antibody-antigen interactions leading to immunoprecipitation. I initially wanted to use a MAb, because the available antiscup P450E MAbs are highly specific for the Fundulus orthologue. It is difficult 
for monoclonal antibodies to form precipitates unless the antigen is multivalent (contains identical repeated antigenic determinants). Thus, I obtained Sepharose 4B-linked affinity purified goat anti-mouse IgG (Organon Teknika-Cappel, Malvern, PA). This bead complex should recognize IgMs as well as IgG classes and it should be possible to elute bound immunoglobulins from the matrix in a biologically active state. After elution of solubilized Fundulus hepatic microsomes and MAb 1-8-4 (an IgM which has a high avidity for P-450E, see Chapter 2, Figure 4) from the Sepharose-antibody column according to the manufacturer's protocol, I immunoblotted the eluate against MAb 1-12-3. Positive controls, aliquots of starting material alone, resulted in a single band in each lane at the appropriate $\mathrm{M}_{\mathrm{r}}$ for P-450E. Eluates reacted with MAb 1-12-3 only as faint fragments at or near the dye front, with no signal apparent in the middle molecular weight range. Thus (although some of the P-450E signal may have been blocked by antibody, see below), I decided to return to immunoprecipitation using polyclonal antibodies (PAb) and immunoprecipitin (formalinized S. aureus containing protein A), as described in Chapter 3 for precipitation of P-450E RNA translation products. Modifications of the immunoprecipitation technique are listed in the Materials and Methods section.

The size of the immune complex depends on the relative concentrations of the two components, so the proper ratio of antibody to antigen was determined. Typically, a bell-shaped curve is produced, with maximal precipitation complexes forming near equivalence (Alberts et al., 83). To establish this ratio and use the same PAb preparation in routine microsomal precipitations, however, greater amounts of PAb were required. Thus, I prepared additional polyclonal antibodies (see Materials and Methods). BNF-treated Fundulus microsomes were solubilized and incubated with the new polyclonal antibody preparation at ratios of 0.1 to 30 
ug PAb/pmol spectral P-450. Immunoprecipitin was added to each mixture to precipitate the antibody-antigen complex. The pellets were washed, then boiled to release the complex and centrifuged to pellet the immunoprecipitin. The supernates were electrophoresed on SDS PAGE minigels, transferred to nitrocellulose and stained with Ponceau S.

Generally, this protein stain is used to confirm that all samples transferred well and that no bubbles occurred in the area of interest. In this case, however, Ponceau S staining indicated the presence of enormous amounts of protein in the 50,000 molecular weight range. Staining after incubation with MAb 1-12-3 and the secondary antibody and color developer resulted in typical signals for the positive controls (non-precipitated Fundulus microsomes), but no signal in this region for the precipitated samples. When the immunoblotted nitrocellulose was directly compared with the Ponceau-staining pattern, and with the Coomassie blue-stained residual gel, the area showing a LACK of immunoblot staining coincided with the area occupied by this protein. Given the concentration of this protein and its $M_{r}$ (IgG heavy chain monomers have a $M_{r}$ of 50,000; Tijssen, 85) in this denaturing gel system, this protein is probably the antibody heavy chain. A second dominant protein-staining band was present at a lower $\mathrm{M}_{\mathrm{r}}$ and presumably corresponds to the antibody light chain (light chain monomers have $\mathrm{M}_{\mathrm{r}} \mathrm{s}$ of 20 25,000). In any case, the results of this experiment are inconclusive. It is possible that the PAb precipitated the P-450E, but its presence was masked by the massive amounts of immunoglobulin heavy chains in this analysis. (This may have been the cause of a negative result with the MAb-Separose bead complex, as well.) Therefore, I decided to carry out an induction experiment in the presence of a radiolabeled compound to generate material which could be detected by radioactive methods. 


\section{Experiment 1: Basic Parameters and [ $3 \mathrm{H}]$-Leucine Incorporation}

Based on the results presented in Chapter 3, steady state levels of BNFinduced P-450E are most likely to occur between 4 and 12 days after treatment with the inducer (Figure 3-1). Therefore, Fundulus were injected with $\left[{ }^{3} \mathrm{H}\right]-$ leucine 4 days after treatment with $50 \mathrm{mg} / \mathrm{kg} \mathrm{BNF}$ and sacrificed 2 and 23 hours later. A "BNF" pool (no leucine injection, $n=4$ ) was prepared at the same time as the 2 hour leucine-treated animals. At each time point, leucine-treated livers were combined to obtain a large pool of labeled material. Results of microsomal analyses and total and TCA counts are shown in Table 5-1. There is no difference between the mean GSI and HSI parameters, indicating that $\left[{ }^{3} \mathrm{H}\right]$-leucine treatment did not affect these parameters in the short term. All other values are for pooled samples, so statistical comparisons are not possible. However, given our previous knowledge of Fundulus MFO characteristics at this time following BNF treatment, and comparing the "BNF" value to the $2 \mathrm{hr}$ and $23 \mathrm{hr}$ values, it appears that $\left[{ }^{3} \mathrm{H}\right]$-leucine treatment did not cause alterations in MFO parameters. Microsomal yield is higher in both leucine-treated pools, but all 3 values fall within the norm for Fundulus preparations.

Radioactive counts are shown in the lower portion of Table 5-1. Liver homogenate counts were calculated relative to the liver wet weight prepared. At 2 $\mathrm{hr}$, TCA counts represented $78 \%$ of the total counts, while at $23 \mathrm{hr}$ they represented $90 \%$ of the total counts. This would be expected of the homogenate pool, if some free leucine was still available after $2 \mathrm{hr}$, but most of the amino acid was incorporated into protein by $23 \mathrm{hr}$. Loss of total label during the experiment (corresponding to oxidative degradation of the amino acid and elimination of label from degraded proteins) was also apparent: the ratio of 23 to $2 \mathrm{hr}$ counts is 0.51 for total counts and 0.59 for TCA counts. 
Table 5-1: $\left[{ }^{3} \mathrm{H}\right]$-Leucine Labeled Fundulus - Single Label Experiment

\begin{tabular}{|c|c|c|c|}
\hline Parameter & BNF & 2 hr Leu & $23 \mathrm{hr}$ Leu \\
\hline \multicolumn{4}{|l|}{ Basic Assays } \\
\hline HSI & $6.3 \pm 1.4(4)^{\mathrm{a}}$ & $5.7 \pm 1.2(10)$ & $5.7 \pm 2.7(10)$ \\
\hline GSI & $3.6 \pm 1.0(4)$ & $3.5 \pm 1.4(10)$ & $3.2 \pm 0.9(10)$ \\
\hline \multicolumn{4}{|l|}{ Microsomes } \\
\hline $\mathrm{b}_{5}^{\mathrm{b}}$ & 52.4 & 55.4 & 61.0 \\
\hline $\mathrm{P}-450^{\mathrm{c}}$ & 326 & 294 & 297 \\
\hline $\mathrm{EROD}^{\mathrm{d}}$ & 1.69 & 1.74 & 2.23 \\
\hline ERODe & 5.19 & 5.92 & 7.51 \\
\hline $\mathrm{P}-450 \mathrm{E} / \mathrm{ng}$ & 156 & 139 & 136 \\
\hline $\mathrm{P}-450 \mathrm{E} / \mathrm{P}-450$ & $48 \%$ & $47 \%$ & $46 \%$ \\
\hline usomal yield & 15.3 & 21.9 & 21.1 \\
\hline \multicolumn{4}{|c|}{$\underline{\text { Radioactive Counts }}$} \\
\hline \multicolumn{4}{|c|}{ liver homogenates } \\
\hline total, dpm/g & & $1.24 \times 10^{7}$ & $6.32 \times 10^{6}$ \\
\hline TCA, dpm/g & & $9.71 \times 10^{6}$ & $5.69 \times 10^{6}$ \\
\hline \multicolumn{4}{|l|}{ liver microsomes } \\
\hline total, $\mathrm{dpm} / \mathrm{mg}$ & & $1.27 \times 10^{5}$ & $4.82 \times 10^{4}$ \\
\hline $\mathrm{TCA}, \mathrm{dpm} / \mathrm{ms}$ & & $1.34 \times 10^{5}$ & $4.96 \times 10^{4}$ \\
\hline
\end{tabular}
a $(n)=$ number of individuals in each pool
b Spectral cytochrome $\mathrm{b}_{5}$, $\mathrm{pmol} / \mathrm{mg}$ protein
c Spectral P-450, pmol/mg protein
d Ethoxyresorufin O-deethylase, $\mathrm{nmol} / \mathrm{min} / \mathrm{mg}$
e Ethoxyresorufin O-deethylase, $\mathrm{nmol} / \mathrm{min} / \mathrm{nmol} \mathrm{P}-450$ 
Liver microsomal counts, calculated relative to $\mathrm{mg}$ protein in the microsomes, present a slightly different picture. At both times, TCA count values were approximately the same as total count values (106\% and 103\%), indicating that all leucine found in the microsomes was incorporated into protein. This is also expected, because any free leucine should not be found in the microsomal fraction, but should be localized predominantly to the cytosol (leucine nonspecifically, loosely, associated with organelles would probably be washed off during subcellular fractionation). The $23 / 2 \mathrm{hr}$ ratio was lower in the microsomal preparation compared to the whole homogenate: 0.38 for total counts and 0.37 for TCA counts. This indicates that release of incorporated leucine may have been more rapid in the microsomes than in the total homogenate (e.g., the "average" microsomal protein half-life was shorter than the "average" total protein half-life).

Finally, I wanted to know the size distribution of radiolabel in the microsomes - is it possible that P-450E was labeled? 10 pmol of spectral P-450 ( 34 ug protein) from the 2 and $23 \mathrm{hr}$ samples were electrophoresed on a large SDS-PAGE gel and autoradiography performed. The 2 hour sample exhibited multiple bands, and the 23 hour sample had two major bands, of 54,700 and $50,600 \mathrm{M}_{\mathrm{r}}$. The higher $\mathrm{M}_{\mathrm{r}}$ band could be P-450E. Taken together, the MFO parameters, total and TCA radiolabel count patterns, and autoradiography results suggest that the labeling protocol chosen for this study should be sufficient for protein labeling in the dual label experiment, and that this concentration of $\left[{ }^{3} \mathrm{H}\right]-$ leucine should be adequate for detectable labeling in BNF-induced Fundulus. In addition, radiolabeled microsomal proteins (probably including labeled P-450E) were now available for further immunoprecipitation experiments. 
Experiment 1: Immunoprecipitation

Once basic MFO parameters and leucine incorporation had been analyzed for the single label experiment, I returned to the question of immunoprecipitation. The method eventually developed is essentially that described in Chapter 3, modified to include microsome solubilization prior to antibody addition. As before, a range of antibody ratios was used ( 0.1 to $20 \mathrm{ug}$ antibody/ pmol P-450), and two concentrations of P-450E carrier were added. The best precipitate complex occurred at 5 ug antibody per pmol total spectral P-450 (Figure 5-1). This ratio was used in all subsequent immunoprecipitations. Results were also improved when a greater amount of P-450E carrier was utilized (Figure 5-1).

This immunoprecipitation protocol was repeated using 2 to $3 \mathrm{mg}$ total protein for the $2 \mathrm{hr}\left[{ }^{3} \mathrm{H}\right]$-leucine sample and the $2 \mathrm{hr}$ "BNF only" sample (no radiolabel added) in duplicate. One sample of each replicate was separated on a wide comb large SDS-PAGE gel and autoradiography performed, the other sample was counted as usual. Counting results are presented in Table 5-2. The $2 \mathrm{hr}$ $\left[{ }^{3} \mathrm{H}\right]$-leucine sample contained $\left[{ }^{3} \mathrm{H}\right]$ counts significantly above background. The pellet contained some counts, but was well below the amounts for the supernate. Additional wash steps after removal of the supernate would probably reduce pellet radiolabel content. (There was obviously sample treatment buffer [blue color] within the immunoprecipitin pellet [white color].) The "BNF" sample contained counts similar to background counts (sample treatment buffer alone). The autoradiogram of the immunoprecipitated $2 \mathrm{hr}\left[{ }^{3} \mathrm{H}\right]$-leucine sample showed a single band, with an approximate $\mathrm{M}_{\mathrm{r}}$ of 57,000 . Thus, this immunoprecipitation procedure appears to isolate a single labeled protein with a size near that of 
Figure 5-1

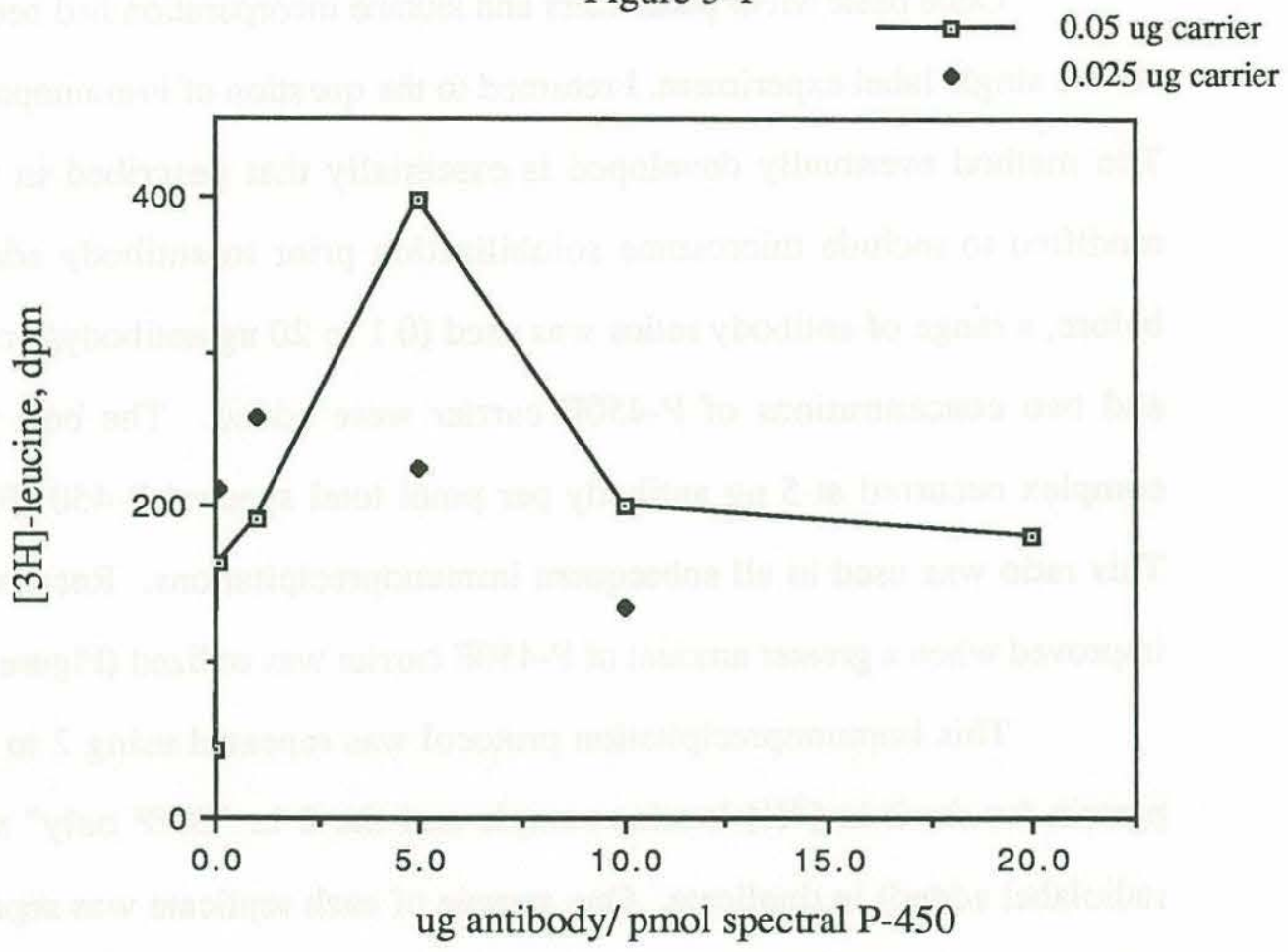

FIGURE 5-1: Ratio of PAb 119 to P-450 protein.

Immunopreciptitation was carried out as described in the Materials and Methods section with Fundulus microsomes from the $2 \mathrm{hr}\left[{ }^{3} \mathrm{H}\right]$-leucine pool and various concentrations of the "new" polyclonal antibody preparation. Two concentrations of scup P-450E were added as a carrier ( 0.05 ug and $0.025 \mathrm{ug}$ ). Results obtained with 0.05 ug scup P-450E content are shown as open squares, results with 0.025 ug as closed diamonds. (P-450E was $47 \%$ of the total P-450 in this sample.) 
Fundulus P-450E. Given the known specificity of this PAb preparation, namely that it does not recognize any other microsomal proteins besides P-450E near that $\mathrm{M}_{\mathrm{r}}$, it is concluded that this band represents labeling of Fundulus P-450E. Therefore, this procedure could be employed for analysis of amino acid and heme incorporation into $\mathrm{P}-450 \mathrm{E}$ in the dual label experiment, providing a means for separating labeled $\mathrm{P}-450 \mathrm{E}$ from remaining microsomal proteins.

Table 5-2: $\left[{ }^{3} \mathrm{H}\right]$-Leucine in Immunoprecipitated Microsomes

amount, spectral P-450 dpm, dpm, sample ID supernate pelleta

$750 \mathrm{pmol}, 2 \mathrm{hr}$ leu 1154 385 750 pmol, BNFb 78 46 background 51 nd

a Samples were immunoprecipitated, washed, boiled in sample treatment buffer to dissociate the antibody/antigen complex from the immunoprecipitin (and itself), and spun down to separate immunoprecipitin from the freed antibody and antigen. Thus, "supernate" values represent antibody and antigen, and "pellet" values represent immunoprecipitin.

b $2 \mathrm{hr} \mathrm{BNF}$ "positive" control (BNF only, no leucine injection)

c sample treatment buffer only

$\mathrm{d}$ nd $=$ not determined 


\section{Experiment 2: Basic Parameters}

The second labeling experiment, designed to provide information on protein and heme turnover in induced Fundulus, was carried out for $190 \mathrm{hr}$ after injection with a dual label. Fundulus were treated with $50 \mathrm{mg} / \mathrm{kg} \mathrm{BNF}$, and injected with $\left[{ }^{3} \mathrm{H}\right]$-leucine and $\left[{ }^{14} \mathrm{C}\right]$-ALA 4 days afterwards. Analysis of MFO activities in these animals is shown in Table 5-3. Cytochrome b5 and P-450 specific contents were significantly different for two time points: b5 specific content at $96 \mathrm{hr}$ was greater than b5 content at 30 or $8 \mathrm{hr}$, and P-450 content at 190 $\mathrm{hr}$ was lower than content at $8 \mathrm{hr}$.

These animals, which were treated in early May, had relatively high GSI values. There were no significant differences between the groups, but the averages for all except the $190 \mathrm{hr}$ time point ranged from 8.9 to 12.5 . The average at $190 \mathrm{hr}$ was 6.2 . All these values are greater than those for the animals treated and analyzed in Chapters 3 and 4 (e.g., compare Table 3-1). The HSI averages ranged from 3.1 to 4.8 , and thus fell in the normal range of values. There has been some debate as to whether "ripe" or gonadally mature female teleosts are capable of a normal P-450 induction response to xenobiotics such as PAH and BNF (McKee et al., 83; Hansson and Gustafsson, 81; Stegeman et al., 82; Stegeman and Woodin, 84). It seems clear from the P-450E protein values that these fish were induced to the same extent as their immature or regressed counterparts (compare P-450E\% column in Table 5-3 with Figure 3-1). Interestingly, microsomal yield was significantly lower in the 96 and $190 \mathrm{hr}$ samples compared to the first two times sampled, 0.5 and $1.5 \mathrm{hr}$ (data not shown). The microsomal yield at the early times was similar to the yield in Experiment 1 (all $21 \mathrm{ug} / \mathrm{g}$ liver), indicating that perhaps injection with $\left[{ }^{3} \mathrm{H}\right]$-leucine does cause 
Table 5-3: Monooxygenase Parameters in "Dual Label" Fundulus

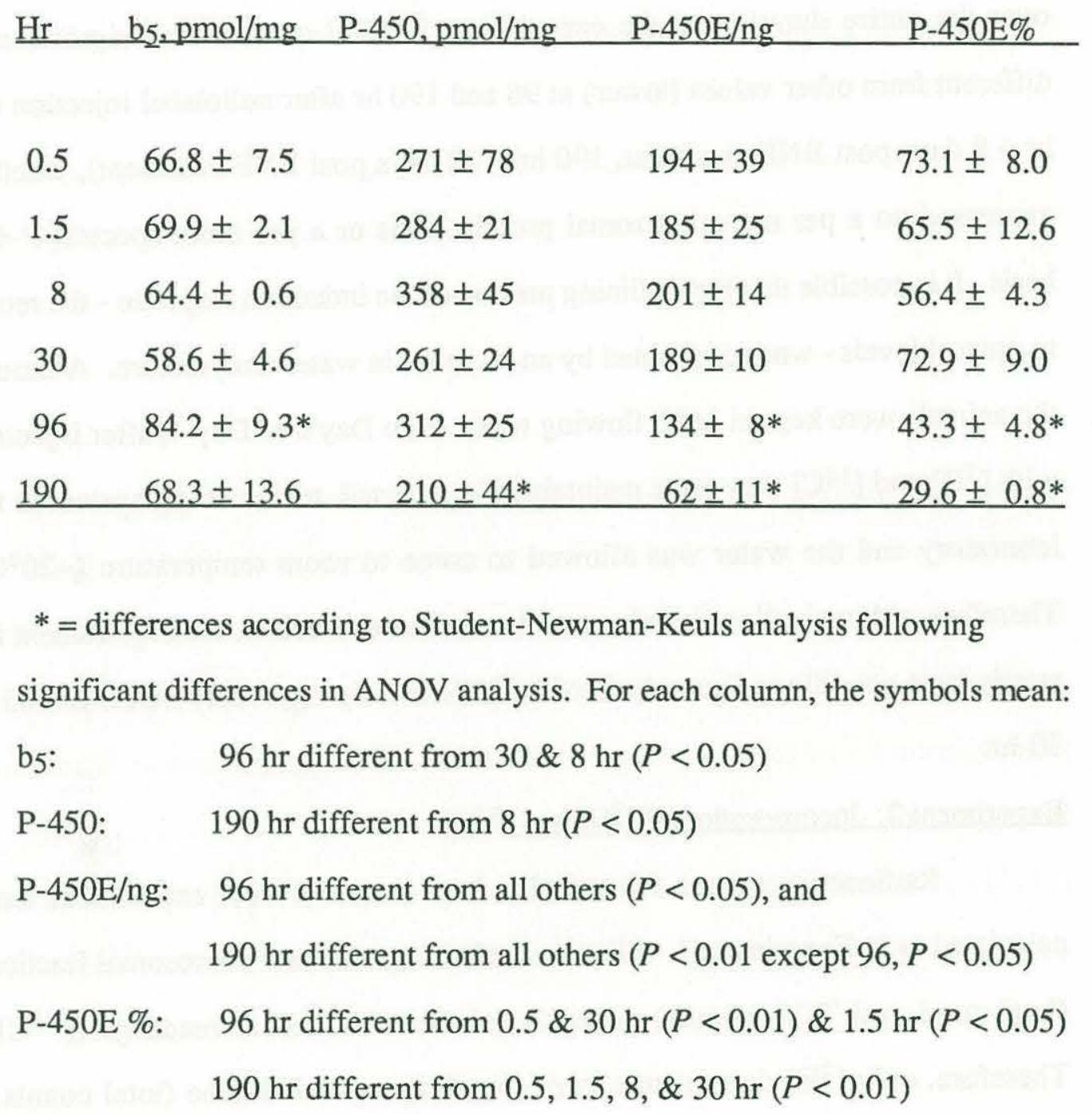

NOTE: HSI and GSI: no significant differences between the groups 
an at least transient increase in microsomal yield. Any link between reduced hepatic microsomal yield at the later time points and reduction in GSI is unknown.

Despite the assumption that $\mathrm{P}-450 \mathrm{E}$ protein content would remain stable over the entire duration of the experiment, P-450E content was significantly different from other values (lower) at 96 and $190 \mathrm{hr}$ after radiolabel injection (96 $\mathrm{hr} \sim 8$ days post BNF treatment, $190 \mathrm{hr} \sim 12$ days post BNF treatment), whether expressed on a per mg microsomal protein basis or a per nmol spectral P-450 basis. It is possible that the declining portion of the induction response - the return to control levels - was accelerated by an increase in water temperature. Although the animals were kept in $16^{\circ} \mathrm{C}$ flowing water from Day 0 to Day 4 , after injection with $\left[{ }^{3} \mathrm{H}\right]$ and $\left[{ }^{14} \mathrm{C}\right]$ they were maintained in a closed, recirculating system in the laboratory and the water was allowed to come to room temperature $\left(\sim 20^{\circ} \mathrm{C}\right)$. Therefore, although all radioactive counts are included below, the requirement for steady state conditions for analysis of half-life is only rigorously met from 0.5 to $30 \mathrm{hr}$.

\section{Experiment 2: Incorporation of $[\underline{3} \underline{\mathrm{H}}]$ and $[\underline{14} \mathrm{C}]$}

Radioactive counts for samples from the dual label experiment were calculated as in Experiment 1. Aliquots for homogenate and microsomal fractions (both total and TCA counts) gave no coherent channel 2 readings $\left(\left[{ }^{14} \mathrm{C}\right]\right)$. Therefore, only $\left[{ }^{3} \mathrm{H}\right] \mathrm{dpm}$ counts, corresponding to total leucine (total counts $=$ free plus incorporated leucine) and incorporation of leucine into protein (TCA counts $=$ incorporated leucine), are plotted in Figure 5-2. Figure 5-2A shows counts from the liver homogenates at each time point, Figure 5-2B shows microsomal counts. In each case, maximal radiolabel incorporation occurred at $1.5 \mathrm{hr}$, followed by a rapid decline. Thereafter, counts remained fairly constant from 30 to $190 \mathrm{hr}$. It is possible that turnover is biphasic, with a rapid phase 
from 1.5 to between 8 and $30 \mathrm{hr}$, and a much slower phase (proteins with a longer half-life) beyond $30 \mathrm{hr}$. The initial decline in microsomal protein is more rapid than the initial decline in homogenate protein (comparison of TCA counts), indicating that "average" microsomal proteins turn over faster than do "average" total proteins. The slight (not statistically significant) increase in labeled protein at $190 \mathrm{hr}$ in all samples tested may be due to a decline in microsomal yield at 96 and $190 \mathrm{hr}$. For example, if labeled proteins were preferentially retained but other proteins were lost, an apparent increase in $\mathrm{dpm} / \mathrm{mg}$ could result. (This is actually unlikely, as most research has indicated that newly synthesized proteins have the same probability of degradation as do older proteins.) The protein half-life can be calculated for the fast and slow phases according to Parkinson et al. (83a). When a straight line is fitted to a semilog plot of specific radioactivity (TCA counts, $\mathrm{dpm} / \mathrm{mg}$ ) vs time, the microsomal fast phase ( 1.5 to $\left.30 \mathrm{hr}, \mathrm{r}^{2}=-0.877\right)$ half-life is $9.3 \mathrm{hr}$ and the homogenate fast phase $\left(1.5\right.$ to $\left.30 \mathrm{hr}, \mathrm{r}^{2}=-0.950\right)$ half-life is $16 \mathrm{hr}$. The slow phases then have half-lives of $190 \mathrm{hr}$ and $140 \mathrm{hr}$, respectively (both measured at 30 and $96 \mathrm{hr}$ only).

Equal amounts of spectral P-450 $(0.90 \mathrm{nmol})$ were used as starting material for immunoprecipitation, at a ratio of $5 \mathrm{ug} \mathrm{PAb} / \mathrm{pmol} \mathrm{P}-450$. The expectation was that $\left[{ }^{14} \mathrm{C}\right]$ would be detectable in these samples, due to the greater specific content of heme in $\mathrm{P}-450$ s as compared to bulk microsomal proteins ( $70 \%$ of microsomal heme is incorporated into P-450 isozymes, Muller-Eberhard and Vincent, 85). A detectable signal was obtained for both isotope channels. This was not due to "spillage" of tritium counts into the second window: the ${ }^{3} \mathrm{H} /{ }^{14} \mathrm{C}$ ratio shifted with time.

$\left[{ }^{3} \mathrm{H}\right]$-leucine per nmol P-450E achieved its peak at $1.5 \mathrm{hr}$ (Figure 5-3), as was observed for "average" microsomal protein (Figure 5-2B, TCA counts). 
Figure 5-2: Incorporation and disappearance of $\left[{ }^{3} \mathrm{H}\right]$-leucine in Fundulus liver homogenate and liver microsome fractions.

BNF-treated fish were sacrificed at various times $(0.5$ to $190 \mathrm{hr})$ after treatment with radiolabel. Radioactivity was measured before (open squares) and after (closed diamonds) TCA precipitation as described in the Materials and Methods section. Means ( $\mathrm{n}=3$ in all but the $190 \mathrm{hr}$ group, where $\mathrm{n}=2) \pm \mathrm{sd}$ are plotted at each time.
A. Liver homogenates, dpm/g liver ( values $\times 10^{5}$ )
B. Liver microsomes, dpm/mg microsomal protein 
Figure 5-2
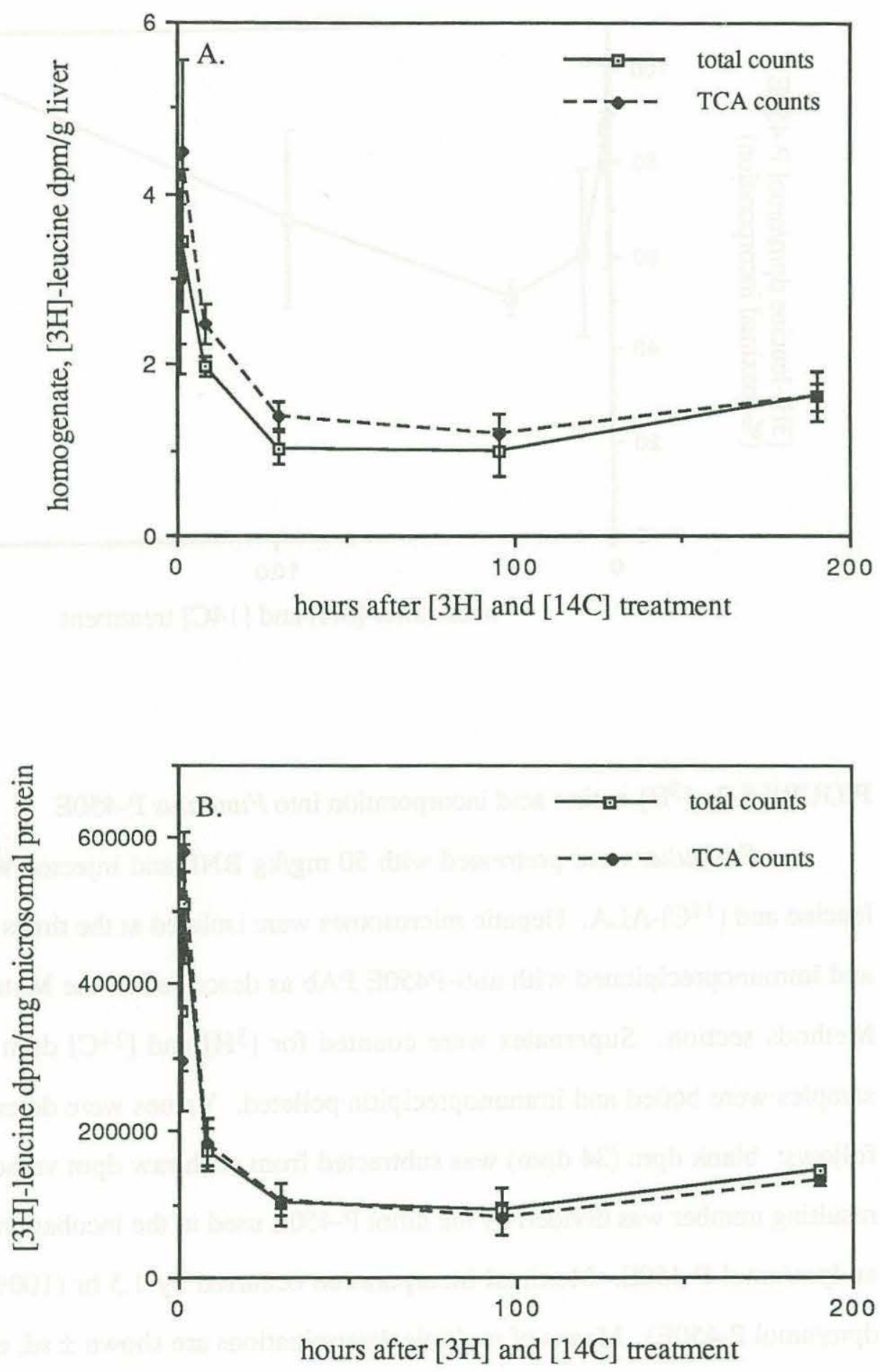
Figure 5-3

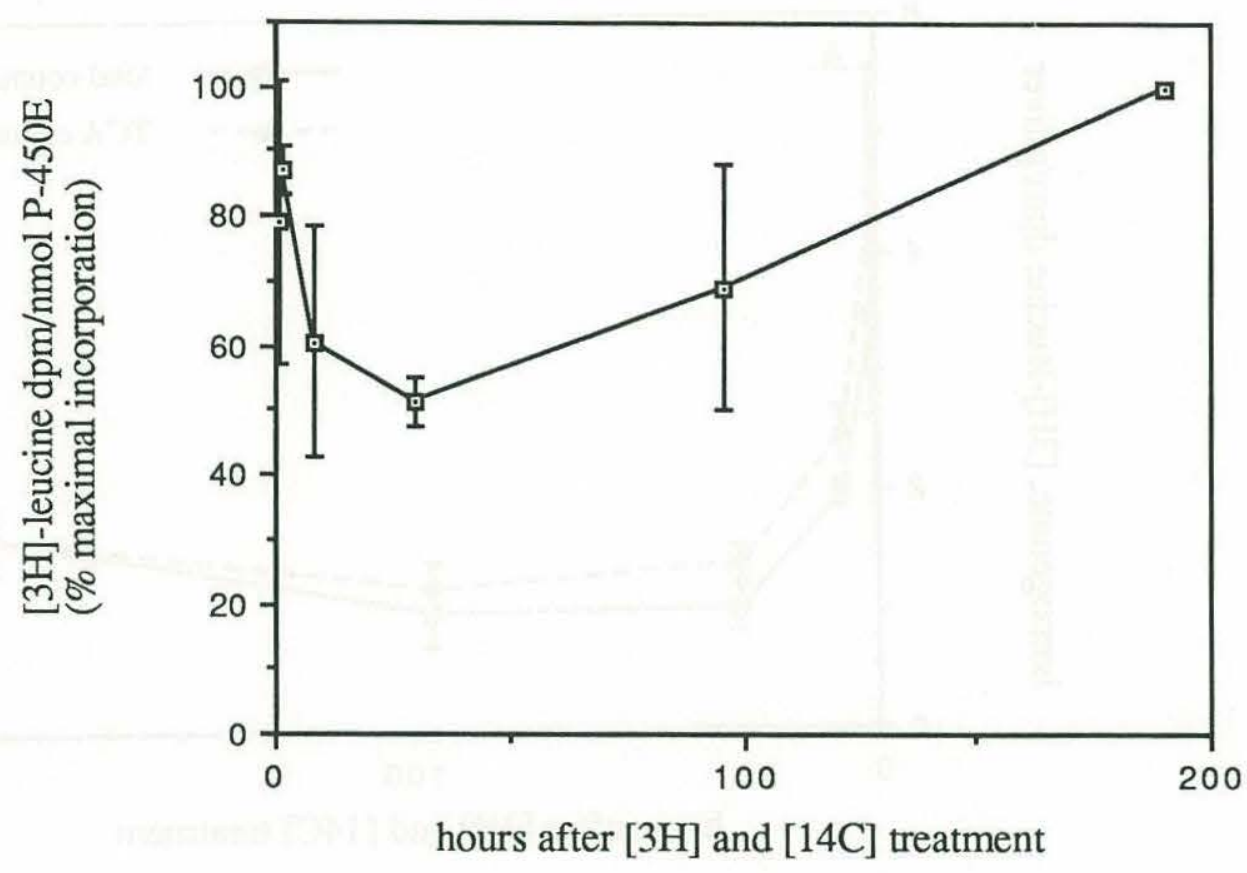

FIGURE 5-3: $\left[{ }^{3} \mathrm{H}\right]$-amino acid incorporation into Fundulus $\mathrm{P}-450 \mathrm{E}$

Fundulus were pretreated with $50 \mathrm{mg} / \mathrm{kg} \mathrm{BNF}$ and injected with $\left[{ }^{3} \mathrm{H}\right]-$ leucine and $\left[{ }^{14} \mathrm{C}\right]$-ALA. Hepatic microsomes were isolated at the times indicated and immunoprecipitated with anti-P450E PAb as described in the Materials and Methods section. Supernates were counted for $\left[{ }^{3} \mathrm{H}\right]$ and $\left[{ }^{14} \mathrm{C}\right] \mathrm{dpm}$ after the samples were boiled and immunoprecipitin pelleted. Values were determined as follows: blank dpm (34 dpm) was subtracted from each raw dpm value, and the resulting number was divided by the nmol P-450E used in the incubation to arrive at $\mathrm{dpm} / \mathrm{nmol}$ P-450E. Maximal incorporation occurred by $1.5 \mathrm{hr}(100 \%=3134$ $\mathrm{dpm} / \mathrm{nmol}$ P-450E). Means of multiple determinations are shown $\pm \mathrm{sd}$, except for at $190 \mathrm{hr}$ (a single determination). 
Rather than the expected constant decline following maximal incorporation, a second increase appeared by $190 \mathrm{hr}$. Possible explanations for this observation are described in the Discussion section. A calculation like those reported above was made for $\mathrm{P}-450 \mathrm{E}$ protein from 1.5 to $30 \mathrm{hr}\left(\mathrm{r}^{2}=-0.873\right)$, with a resultant half-life of $32 \mathrm{hr}$. It takes Fundulus approximately 4 days to achieve the induced steady state level of P-450E after a single i.p. injection of $50 \mathrm{mg} / \mathrm{kg}$ BNF (Figure 3-1). A rough estimate of the time required for $\mathrm{P}-450 \mathrm{E}$ to reach one half its steady state level, as described by Berlin and Schimke (65), provides a half-life of $43 \mathrm{hr}$ (based on P-450E/total P-450 values). Thus, there is a reasonable agreement between the two methods. It must be stressed that only the earlier time points were employed for the determination of half-life by isotope decay. Figure 5-3 suggests that some puzzling phenomenon may be occurring at later times (a stabilization of a subpopulation of P-450E? differential precipitation of $\mathrm{P}-450 \mathrm{E}$ at different concentrations?)

Incorporation of $\left[{ }^{14} \mathrm{C}\right]-\mathrm{ALA}$ into $\mathrm{P}-450 \mathrm{E}$ over time resulted in a more consistent picture (Figure 5-4). $\left[{ }^{14} \mathrm{C}\right]$ achieved maximal incorporation by $8 \mathrm{hr}$, indicating a lag between incorporation of leucine into the apoprotein and incorporation of the heme moiety (maximal leucine incorporation occurred at 1.5 $\mathrm{hr}$ ). The subsequent decline in $\left[{ }^{14} \mathrm{C}\right] \mathrm{dpm} / \mathrm{P}-450 \mathrm{E}$ was relatively slow, with a calculated $\mathrm{t}_{1 / 2}$ (half-life) of $104 \mathrm{hr}$ (calculated from 8 to $190 \mathrm{hr}, \mathrm{r}^{2}=-0.932$ ). This determination included more time points than did the protein determination, but also included those later in the experiment, which may be susceptible to problems (see below). 
Figure 5-4

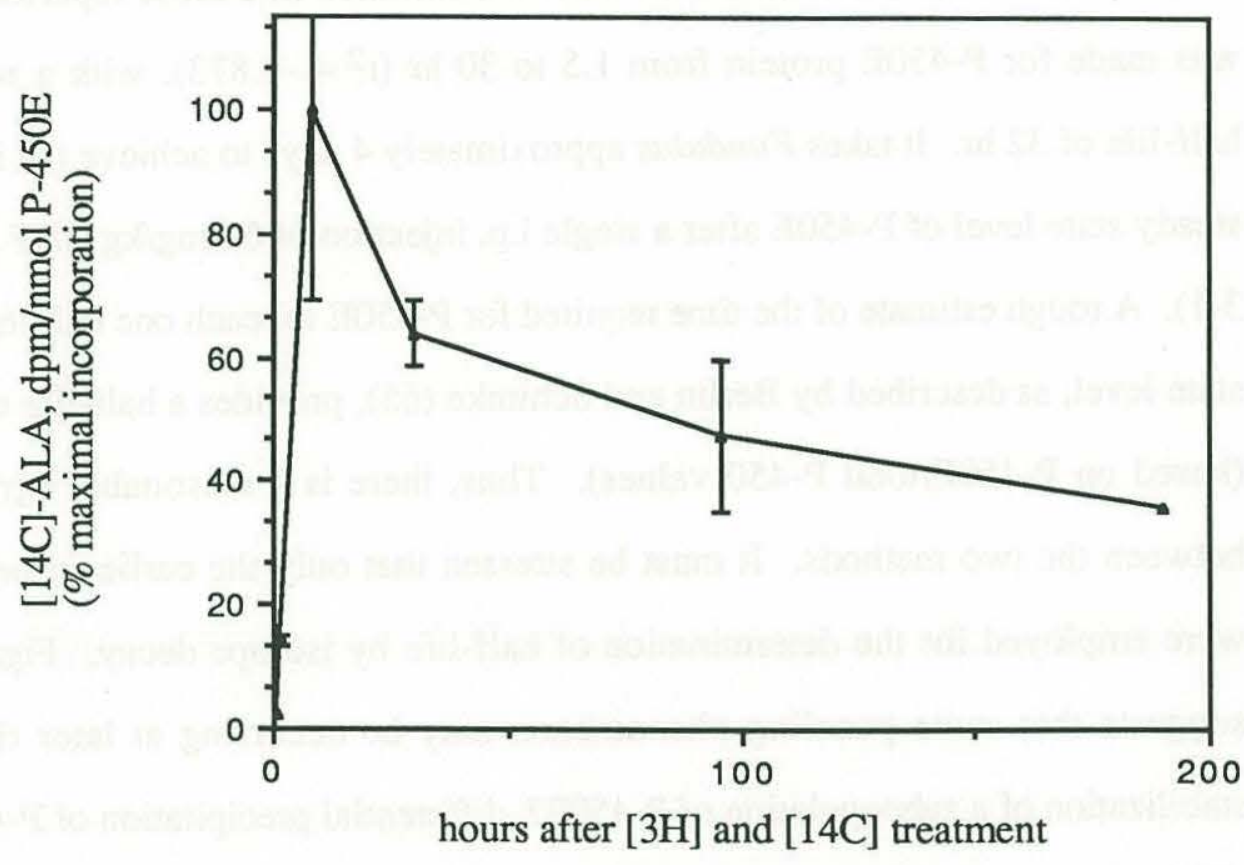

Figure 5-4: $\left[{ }^{14} \mathrm{C}\right]$-heme incorporation into Fundulus $\mathrm{P}-450 \mathrm{E}$

Fundulus were treated and microsomal P-450E precipitated as described in Figure 5-3. The same samples were analyzed for both amino acid and heme labeling; calculations were performed as outlined in Figure 5-3. Maximal incorporation of ALA occurred by $8 \mathrm{hr}$ (blank was $26 \mathrm{dpm}$, and corrected $100 \%=531$ $\mathrm{dpm} / \mathrm{nmol}$ P-450E). Means of multiple determinations are shown $\pm \mathrm{sd}$, except for at $190 \mathrm{hr}$ (a single determination). 


\section{Discussion}

In studies of induction of mammalian xenobiotic-inducible P450IA1 by $\mathrm{BNF}$, protein and enzymatic activity levels exhibit the same trend as does the corresponding mRNA: an initial sharp increase to a maximal value, followed by a rapid decline to control levels (Boobis et al., 77). The pattern is somewhat different in teleost species examined thus far. It has been known for some time that induction of $\mathrm{AHH}$ and EROD activities in fish can persist for weeks (James and Bend, 80; Andersson et al., 85). The studies described in Chapters 3 and 4 confirm that this prolonged catalytic activity is highly correlated with the presence of the AHH/EROD catalyst itself, the P-450E protein (e.g., Figure 4-4 and Figure 3-1). These studies also demonstrate that P-450E mRNA levels decline relatively rapidly, approaching control levels by 4 days after treatment (Figure 4-8). This suggests that while mammalian P450IA1 protein has a relatively rapid turnover, fish P450IA1 may not. Therefore, it was of interest to address questions of teleost $\mathrm{P}-450 \mathrm{E}$ protein and heme turnover.

The Introduction to this Chapter outlines some of the theories and experimental methods in use for the measurement of protein and heme turnover. Unfortunately, the most promising amino acid precursor for liver studies bicarbonate - is not feasible for use in teleosts, due to basic differences in excretory physiology between mammals and fish. I employed $\left[{ }^{3} \mathrm{H}\right]$-leucine (frequently used in fish protein turnover studies, whcih generally measure bulk protein turnover in various organs) as an amino acid precursor.

Experiment 1 was conducted to supply radiolabeled material for improved interpretation of immunoprecipitation results and also as a preliminary labeling study. Only two time points were chosen, but they proved to be at critical

periods - $2 \mathrm{hr}$ was near peak label incorporation, and $23 \mathrm{hr}$ was near the end of the 
most rapid phase of label loss, as determined in Experiment 2. Leucine was readily taken up into the TCA-precipitable (protein) fraction in both whole homogenates and microsomes. As expected, some free leucine was present in the homogenate, but none was detectable in the microsomal fraction (microsomal TCA counts $\sim$ total counts). The added pulse of leucine (or any side effects caused by the injection) did not appear to affect the MFO parameters measured, for at least 23 $\mathrm{hr}$ after injection (Table 5-1). The presence of labeled material facilitated interpretation of immunoprecipitation results, and allowed me to establish an antibody to antigen ratio (5 ug PAb/pmol P-450) in the reactions (Figure 5-1). Autoradiography showed that P-450E, or a protein of similar molecular weight, had incorporated the leucine label and could be precipitated as a single band of the expected $\mathrm{M}_{\mathrm{r}}$ with the new polyclonal antibody preparation.

Experiment 2 was designed to give more detailed information on protein turnover, particularly P-450E turnover, and on initial heme turnover results. Before discussing these results, however, it is interesting to note that BNF was able to elicit a typical P-450E induction response in females having high GSI values. P-450E was elevated to levels similar to those found in BNF-treated immature females (compare Table 5-3 with Figure 3-1). It is not known what the circulating estradiol levels were in the blood of these females prior to and during xenobiotic treatment, but the animals were obviously closer to a mature reproductive status than were the animals used in the earlier September and February studies (post-spawning and regressed status). It is possible that a combination of conditions such as day length, temperature, and steroid levels at the time of xenobiotic exposure in these laboratory-held animals caused them NOT to exhibit the more common LACK of strong induction seen when sexually mature females are challenged by these chemicals (Gray, 88, and references therein). 
Experiments specifically designed to address questions of suppression of the induction response in teleosts by female sex steroids are underway (Adria Elskus, personal communication).

The levels of $\left[{ }^{14} \mathrm{C}\right]$ were too low in homogenates and microsomal preparations to obtain detectable counts, but $\left[{ }^{3} \mathrm{H}\right]$-leucine was incorporated into protein as previously observed in Experiment 1. Peak incorporation occurred at $1.5 \mathrm{hr}$, and the rapid phase of protein turnover was calculated according to the method of Parkinson et al. (83a) to be $9.3 \mathrm{hr}$ for microsomes and $16 \mathrm{hr}$ for homogenates. The slower phases were calculated to have $\mathrm{t}_{1 / 2} \mathrm{~S}$ of $190 \mathrm{and} 140 \mathrm{hr}$, respectively. These results are comparable in trend to those of Parkinson et al. (83a), where the average rat microsomal protein had fast and slow $t_{1 / 2} s$ of $5-9$ and $82 \mathrm{hr}$, faster than the average homogenate protein. Arias et al. (69) obtained a determination of 3 days for average rat microsomal protein half-life.

The results obtained by immunoprecipitating P-450E protein are puzzling. Although a peak of $\left[{ }^{3} \mathrm{H}\right]$ occurred simultaneously with the peak in average microsomal protein (1.5 hr, Figure 5-2 and Figure 5-3), $\left[{ }^{3} \mathrm{H}\right]$ counts again increased by $190 \mathrm{hr}$. There are several possible explanations for these results, including methodological difficulties and reutilization of the radiolabel. Due to a decline in P-450E\% at the last two time points, less P-450E was present in the 96 and $190 \mathrm{hr}$ sample immunoprecipitation incubations. I corrected for this by a simple calculation which assumes linearity of the response. However, a difference in total protein concentration, or in the ratio of the antibody to the antigen itself may result in a non-linear relationship (the antibody to total P-450 ratio was the same for each incubation, but the antibody to P-450E ratio was in excess for the last two time points). Repetition of these immunoprecipitation assays with a range of $\mathrm{P}-450 \mathrm{E}$ contents at constant protein concentration, and conversely with a range 
of protein contents at constant P-450E levels could help eliminate this possible source of error.

Reutilization is another possible problem. The incorporated label could be identified by hydrolysis and thin layer chromatography of the sample to determine whether label occurs only as leucine, or as other amino acids. Use of Arias et al.'s (69) dual label technique, or another precursor in the place of leucine, are possible methodological alternatives. GSI decreased in the animals with time, which may indicate accumulated stresses of the closed system or long-term effects of the injections. Finally, the rise in water temperature may have increased protein synthesis, leading to enhanced reutilization (such as that observed in PBstimulated rats by Arias et al., 69; Sadano and Omura, 82). In conclusion, it is not possible to make a realistic estimate of the turnover of P-450E apoprotein with these few data points. (The "unrealistic" estimate of $t_{1 / 2}, 32 \mathrm{hr}$, is in close agreement with the estimated time to reach a half-maximal induced state, about 43 hr.) It is also possible that this second peak in $\left[{ }^{3} \mathrm{H}\right]$ incorporation is real, and reflects a stable sub-population of $\mathrm{P}-450 \mathrm{E}$ protein.

The incorporation of $\left[{ }^{14} \mathrm{C}\right]$-ALA lagged behind $\left[{ }^{3} \mathrm{H}\right]$-leucine incorporation ( $8 \mathrm{vs} 1.5 \mathrm{hr}$ ). Parkinson et al. (83a) observed a similar lag between apoprotein and heme uptake in Aroclor-treated rats. Sadler et al. (85) observed maximal incorporation of ALA into trout microsomal proteins at 20 to $25 \mathrm{hr}$ (at $6^{\circ} \mathrm{C}$ ). The estimated half-life for heme, using the same calculation method as described above, was $104 \mathrm{hr}$ in Fundulus. The $\left[{ }^{14} \mathrm{C}\right]$ values seemed more consistent than the $\left[{ }^{3} \mathrm{H}\right]$ values, with lower deviations from the mean values and a more expected pattern (no secondary increase in levels). In mammalian species, ALA is considered to be a good label of heme, due to its specific incorporation into heme and the subsequent degradation of heme without label recycling. The 
infrequent reports of heme "switching" in mammalian P-450s suggest that the results obtained here may not be wholly artifactual: heme switching may account for the longer half-life observed for heme compared to apoprotein in Fundulus P-450E.

It would be of interest to measure heme content in microsomes prior to and after P-450E precipitation, and compare these numbers with the radioactive counts obtained (specific radioactivity on a heme, rather than protein, basis). This would confirm that immunoprecipitation of P-450 isozymes from solubilized microsomes with polyclonal antibodies does not cause the loss of heme from the apoprotein (Parkinson et al., 83a; Meier et al., 84). The samples precipitated and separated on SDS-PAGE each exhibited a single band at between 55 and $60 \mathrm{kD}$ $\mathrm{M}_{\mathrm{r}}$, and only one of two with high $\left[{ }^{14} \mathrm{C}\right]$ values had a lower $\mathrm{M}_{\mathrm{r}}$ band as well. Knowledge of the dpm incorporated per unit heme may be more useful for consideration of the role heme plays in the regulation of P-450E expression. There is no evidence that xenobiotics induce ALAS in teleosts (e.g., Gooch and Matsumura, 83), despite frequent increases in total spectral P-450 content. Perhaps heme is not limiting in these cases, or some element of the regulatory pathway is nonfunctional in teleosts and heme is in fact a limiting factor. My results indicate that the apoprotein moiety of P-450E turns over at a more rapid rate than does the heme moiety, in contrast to most of the evidence in mammalian systems. Improvements of the experimental protocol, besides further optimization of the immunoprecipitation method, include: strict temperature control, fewer animals per tank in the recirculating system, less frequent feedings (water fouling), and a longer and more intensive sampling regime. Attempts to precipitate the radiolabeled material with the antibody-bead complex described in the 
Immunoprecipitation - Early Attempts section may also prove to be a fruitful avenue, especially as the beads can be reused.

The results presented in the other Chapters of this thesis supplied solid background material and answered fundamental questions concerning aspects of the regulation of $\mathrm{P}-450 \mathrm{E}$ induction in teleosts, while opening up further avenues of investigation. The results presented in Chapter 5 pose more questions than they answer. I have established that radiolabeling of P-450E is possible in Fundulus, worked out a scheme for isolation of the P-450E from the remaining microsomal proteins, and obtained radioactive counts from a preliminary dual label experiment. Optimization of the immunoprecipitation procedure, use of healthy animals and careful monitoring of their status during and following treatment are areas for future improvements, which should lead to a better understanding of protein and heme turnover in P-450E.

During the course of this research, much has been learned about the processes of induction of P450IA1 in fish. Chapter 6 summaries the results and conclusions gleaned from my studies of P-450E expression in Fundulus, mentions some advances occurring elsewhere in this field, and provides some thoughts on future directions of research concerning the questions of regulation of the induction of P-450E in teleosts. 
${ }^{1}$ If synthesis is zero order and degradation is first order, then the time it takes a protein to reach half of the new induced steady state level is theoretically equal to the $t_{1 / 2}$. If $E=$ enzyme concentration, $k_{S}=$ rate of synthesis, and $k_{d}=$ rate of degradation, the change in $\mathrm{E}$ over time is: $\mathrm{dE} / \mathrm{dt}=\mathrm{k}_{\mathrm{S}}-\mathrm{k}_{\mathrm{d}} \mathrm{E}$. At induced steady state levels of $E(d E / d t=0), k_{S}=k_{d} E$. Therefore, $k_{d}=k_{S} / E$. If half-life is defined as $\mathrm{t}_{1 / 2}=\ln 2 / \mathrm{k}_{\mathrm{d}}$ or $0.693 / \mathrm{k}_{\mathrm{d}}$, then by rearrangement $\mathrm{t}_{1 / 2}=(0.693 \times \mathrm{E}) / \mathrm{k}_{\mathrm{S}}$. 
184 
CHAPTER 6

SUMMARY AND CONCLUSIONS

I. Regulation of P-450E Induction in Fundulus heteroclitus 186

II. Speculations and Future Directions 192 


\section{Regulation of P-450E Induction in Fundulus heteroclitus}

Regulation of the expression of the mammalian AHH catalyst, P450IA1, involves an $A h$ receptor that forms a complex with TCDD, MC, BNF, or other specific ligands and interacts with some portion(s) of the sequence $5^{\prime}$ of the P450IA1 protein coding region (Whitlock, 87; Nebert and Gonzalez, 87). This interaction leads to transcriptional activation of the gene, resulting in accumulation first of P450IA1 mRNA, then of P450IA1 protein. Thus, increases in the corrresponding enzyme activities are observed. An $A h$ receptor was originally postulated to exist based on structure-activity relationships of TCDD-analogs and AHH activity (Poland and Glover, 73), and the responses in various mouse strains. Availability of defined mouse strains and manipulation of these strains (matings, backcrosses, etc.) allowed for the definition of the $A h$ locus on a genetic basis (Nebert and Jensen, 79). Using techniques exploiting the tight, specific binding of radiolabeled TCDD to the $A h$ receptor, this receptor has now been identified in other mammals, including rabbits, guinea pigs, and humans (Gasiewicz and Rucci, 84; Manchester et al., 87).

When I began my studies of the molecular regulation of induction of teleost P-450E, all attempts to find a corresponding $A h$ receptor moiety in fish had been unsuccessful, despite efforts to optimize the assays for tissues containing low concentration or labile receptors (Denison et al., 85; Hamilton, personal communication). Thus, I decided to attack the question from another angle: if transcriptional enhancement is a fundament part of P450IA1 induction in mammals (Gonzalez et al., 84), is this also the case in fish? This might seem a rather obvious hypothesis. However, taking the relatively long times needed to achieve maximal AHH and EROD activities in fish and the inability to identify an $A h$ 
receptor into account, it was postulated (Denison et al., 85) that the mechanism was fundamentally different from that known to exist in mammals.

The wealth of background information on the enzyme itself and the availability of antibody probes for identification and measurement of P-450E protein and mRNA levels led me to examine the mechanism of regulation of the xenobiotic-metabolizing teleost isozyme P-450E. Prior to addressing questions of temporal patterns of induction, to approach an understanding of the underlaying mechanisms, I further characterized the available anti-scup P-450E antibodies (Klotz et al., 83; Park et al., 86a). The MAbs proved to be particularly valuable for immunoblot analysis. MAb 1-12-3 was specific for P-450E, not recognizing any other P-450 fractions, nor other microsomal proteins separated on large or small simple or gradient SDS-PAGE gels. This MAb also recognized a single, xenobiotic-inducible protein in all fish species tested. Of special interest was the reactivity of the antibody with the Fundulus P-450E orthologue. As expected, MAb 1-12-3 recognized a single, BNF-inducible band, which had a $M_{r}$ near that of scup P-450E. MAb 1-12-3 also strongly inhibited EROD activity in hepatic microsomes from induced scup and trout. Thus, the antibody is specific not only for the denatured protein separated by SDS-PAGE, but also for the protein in its catalytically competent state in the microsomal membrane. This antibody was utilized in all measurements of P-450E protein levels in control and BNF-treated Fundulus.

The PAb, which recognized only P-450E out of the five scup P-450 fractions available, also faintly recognized other microsomal proteins. This recognition of non-specific (and non-inducible) proteins was of greatest intensity in scup, and was reduced in Fundulus. Fortunately, proteins at $\mathrm{M}_{\mathrm{r}} \mathrm{s}$ near the P-450E orthologue were not recognized by the PAb in the immunoblotting 
technique. PAb inhibited EROD and $\mathrm{AHH}$ activity, but did not affect aminopyrine $\mathrm{N}$-demethylase activity (which is known to be catalyzed by non-P450IA1 isozymes in mammals). PAb also partially inhibited ethoxycomarin O-deethylase activity (which is known to be catalyzed by P450IA1 plus other isozymes in mammalian microsomes). These results are all consistent with the specificity indicated by the immunoblot results: the antibody interferes with the catalytic function of the P-450E isozyme, but not with the functioning of other isozymes, in the microsomal environment. Precipitation was chosen for separation of the P-450E components from remaining cellular components. Because lattice formation is crucial for immunoprecipitation, PAb were preferred over MAb for such assays. These polyclonal antibodies were invaluable for precipitation of both RNA translation products and microsomal P-450E.

Once the antibodies were characterized and shown to have the necessary specificity for P-450E, and reactivity with P-450E in a variety of species, I could use them in addressing questions of regulation of P-450E induction. The mode of $\mathrm{PAH}-$ type induction was investigated by examining hepatic P-450E isozyme content, EROD catalytic activity, and P-450E mRNA levels in Fundulus after exposure to a single dose $(50 \mathrm{mg} / \mathrm{kg})$ of BNF. First, the temporal patterns of $\mathrm{P}-450 \mathrm{E}$ protein and EROD activity induction at $16^{\circ} \mathrm{C}$ were established. In a 20 day experiment, EROD activity was significantly elevated in BNF-treated animals compared to corn oil-treated controls from Day 4 through Day 20. Immunodetectable P-450E showed the same trend, with consistently low control values and at least a 19-fold increase in the BNF-treated fish. P-450E protein and EROD activity were highly correlated $\left(\mathrm{r}^{2}>0.9\right.$ for all individuals), as expected if $\mathrm{P}-450 \mathrm{E}$ is the BNF-inducible EROD catalyst. P-450E protein increased from control levels of about $5 \%$ of the microsomal P-450 population to up to $75 \%$ in 
BNF-treated animals. (Because purified P-450E is not available for the killifish, these numbers are based on the assumption that MAb 1-12-3 has the same affinity for Fundulus P-450E as for the standard, scup P-450E, and that protein effects do not alter the detectable signal in a purified preparation compared to a microsomal sample.)

High levels of DNase activity had been observed during scup, winter flounder, and Fundulus hepatic DNA isolation experiments (E. Metz and P.J. Kloepper-Sams, unpublished observations). This activity was not seen for trout hepatic tissue or for scup or trout gonadal tissue, indicating that the nucleases were not introduced by experimental error or contamination. Thus, to avoid possible similar problems with hepatic RNA isolation, I employed a method designed for extraction of intact RNA from pancreatic tissue, which has extremely high levels of RNase activity (Chirgwin et al., 79). Teleost RNA was isolated with the guanidine thiocyanate method, resulting in typical OD 260/280 ratios of 2.0. The RNA exhibited 2 bands corresponding to the two major moieties found in total RNA, the large and small subunit ribosomal RNA, when electrophoresed on formaldehyde/agarose gels. Thus, the preparations appeared to be free of protein and phenol contamination and to contain full-size RNA. After preliminary experiments to establish favorable RNA concentrations and translation conditions, the RNA was used in in vitro translation reactions in the presence of $\left[{ }^{3} \mathrm{H}\right]$-leucine. Precipitation of Fundulus liver RNA translation products with anti-P-450E PAb gave no detectable signal from control fish, while BNF-treated animals showed incorporation of $\left[{ }^{3} \mathrm{H}\right]$-leucine into a single $56,000 \mathrm{M}_{\mathrm{r}}$ band.

In a shorter term experiment (48 hr), EROD activity and P-450E levels were again coordinately increased in response to BNF treatment. These values corresponded well with the values obtained in the 20 day experiment, indicating 
that these animals were following the same time course of P-450E and EROD induction. Immunoprecipitation of translation products from the BNF-treated fish showed increased signal for all time points 6 hours or more post-treatment. The control P-450E mRNA levels were all below the limits of detection. Thus, a second method of P-450E mRNA detection was developed and employed.

cDNA pfP $1450-3$ ' encodes the rainbow trout P450IA1 gene (Heilmann et al., 88). Although non-radioactive detection techniques provided ambiguous results, the cDNA nick-translated in the presence of $\left[{ }^{32} \mathrm{P}\right]-\mathrm{dCTP}$ yielded discrete, unique hybridization bands on Southern blots with scup, trout and Fundulus genomic DNA. A Northern blot of RNA from control and BNF-treated Fundulus showed increases in a single band in the BNF samples with time when probed with the [32P]-labeled trout cDNA. The control was detectable using this probe, and by $6 \mathrm{hr}$ the signal was strongly increased over the control, as expected based on the translation/immunoprecipitation data. P-450E mRNA increases preceded P-450E protein and enzyme activity increases by about $25 \mathrm{hr}$, supporting the hypothesis that transcriptional enhancement is involved in induction of PAHinducible P-450s in fish. In another BNF experiment, protein and mRNA levels were examined for a longer time period, to ensure that a secondary peak in P-450E mRNA, or maintenance of a moderate, sub-maximal level of mRNA, was not responsible for the persistence of the P-450E protein as seen in the 20 day experiment. Fundulus P-450E mRNA levels declined rapidly, reaching control levels by 5 days, while protein and activity levels remained elevated for at least 13 days. Thus, P-450E induction appears to be not only regulated by transcriptional enhancement, but also by other forms of regulatory control.

Given the differences between mRNA and protein patterns, it was interesting to determine whether P-450 protein has an extremely long half-life. 
Although various studies have examined bulk protein turnover in different fish tissues, I found no reports focusing on specific proteins. Microsomal protein, P-450E protein, and P-450E heme half-lives $\left(\mathrm{t}_{1 / 2}\right)$ were examined in Fundulus under conditions of elevated P-450E expression. Decay in incorporated radiolabel $\left(\left[{ }^{3} \mathrm{H}\right]\right.$-leucine and $\left.\left[{ }^{14} \mathrm{C}\right]-\mathrm{ALA}\right)$ was followed over time. The immunoprecipitation method used for RNA translation products was modified for precipitation of $\mathrm{P}-450 \mathrm{E}$ protein from microsomes. A preliminary $\left(\left[{ }^{3} \mathrm{H}\right]\right.$-leucine only) experiment indicated that Fundulus microsomes contained no free radiolabeled amino acids at 2 or $23 \mathrm{hr}$ after injection, and that specific radioactivity was higher at 2 than at 23 hr.

In a longer experiment, $\left[{ }^{14} \mathrm{C}\right]$ counts were not detectable in total microsomes, but a peak of $\left[{ }^{3} \mathrm{H}\right]$ incorporation into microsomal protein was observed at $1.5 \mathrm{hr}$ after injection, followed by a rapid decrease and a stabilization at $30 \mathrm{hr}$. A calculation (Parkinson et al., 83a) of the "rapid" and "slow" phases indicated that "average" (summed, bulk) microsomal proteins had a "fast" $\mathrm{t}_{1 / 2}$ of $9.3 \mathrm{hr}$ and a "slow" $\mathrm{t}_{1 / 2}$ of $190 \mathrm{hr}$. Both $\left[{ }^{14} \mathrm{C}\right]$ and $\left[{ }^{3} \mathrm{H}\right]$ were detectable in PAbprecipitated P-450E. Leucine incorporation peaked at $1.5 \mathrm{hr}$, with a second peak at $190 \mathrm{hr}$. Using only the early time points, P-450E protein was calculated to have a $t_{1 / 2}$ of $32 \mathrm{hr}$. This was consistent with the $43 \mathrm{hr}$ calculated from the time for P-450E to reach half the induced steady state (Berlin and Schimke, 69). Incorporation of $\left[{ }^{14} \mathrm{C}\right]$ into $\mathrm{P}-450 \mathrm{E}$ peaked at $8 \mathrm{hr}$, indicating a lag between leucine and ALA incorporation into the holoenzyme. The subsequent decline in $\left[{ }^{14} \mathrm{C}\right]$ was relatively slow, leading to a calculated heme $t_{1 / 2}$ of $104 \mathrm{hr}$. Further studies of heme and apoprotein turnover will be needed to firmly establish the roles of these players in the regulation of $\mathrm{P}-450 \mathrm{E}$ expression. 


\section{Speculations and Future Directions}

The results presented in this thesis provide some answers to the questions of how this complex system of induction might be controlled, but also indicate additional avenues of investigation. In addition, the techniques developed here can be used to examine a much broader range of environmental and regulatory questions (as is already underway with the use of MAb 1-12-3 in immunoblots for examination of P-450E orthologue levels in a variety of species, including birds and whales). I would like to indicate briefly some of these fields of investigation, and include some areas which were not directly addressed in my laboratory work, but will soon be amenable to experimentation as the proper analytical tools become available.

One of the first areas for expansion on our understanding of teleost P450IA1 induction is to confirm that transcription rates are enhanced prior to increases in P-450E mRNA levels. Isolation of nuclei can be adapted from the techniques of Gonzalez et al. (84), and the trout cDNA probe can be used to quantitate the RNA produced by nuclear run-off experiments. It might be useful to turn to the use of short oligomeric probes, rather than the $1.4 \mathrm{~kb}$ cDNA now available. Solution hybridization techniques result in much more rapid, and sensitive, detection capabilities. Thus, it would be possible to obtain good values for all control animals, have more confidence in the fold induction occurring, and process multiple samples routinely. Some technical problems must be faced prior to the use of this method, however. Use of short "oligos" requires detailed knowledge of the nucleotide sequence of the gene in question - several mismatches within the necessary 20 to 30 basepairs would probably result in S1 nuclease attack in this region and lead to incorrect results. The trout P450IA1 gene has been sequenced (Heilmann, et al., 88), but it is not known how similar the scup, 
Fundulus and winter flounder sequences are to the trout sequence. Although the sequences of the scup and trout amino-terminal ends are known (Table 3-5), an area such as the heme-binding region may be more highly conserved across multispecies boundaries. Ideally, a suite of oligomeric probes (one per species) or a probe which recognizes a sequence identical in all routinely analyzed fish should be made. Sequencing of a putative common region in several teleost species could be accomplished by employing PCR (polymerase chain reaction) methods.

One aspect of the induction response, which can be easily manipulated in poikilotherms and may provide new insights into the induction process, is temperature dependence. Fundulus were chosen as experimental animals partially due to their tolerance of a wide range of temperatures. It would be interesting to conduct a time course experiment similar to those in Chapter 4, and compare P-450E mRNA and protein levels over time at high and low temperatures. Stegeman found no apparent $\mathrm{AHH}$ induction in Fundulus after $96 \mathrm{hr}$ at $6^{\circ} \mathrm{C}$, while animals held at $16.5^{\circ} \mathrm{C}$ were responsive (Stegeman, 79). It is likely that at later times, Fundulus at low temperatures would exhibit responsiveness to inducers. The turnover of mRNA, protein, and heme may also be affected by temperature. Thus, changes in water temperature may allow the investigator to "tease apart" the mechanisms that may occur so rapidly in mammals as to appear to be causally linked.

A single report has proved evidence for an $A h$ receptor-like moiety in teleosts (Heilmann et al., 88). Interestingly, these researchers employed a method which was unsuccessful in other hands (Denison et al., 85). Others were unable to identify a fish $A h$ receptor, although employing more recent and more sensitive techniques (J. Hamilton, personal communication). Preliminary results with scup and winter flounder cytosols were also inconclusive (M.E. Hahn, unpublished 
observations). The imminent availability of anti- $A h$ receptor antibodies may provide the sensitive probes needed to address this question more fully in a number of non-mammalian species. It is likely that an $A h$ receptor, if present in fish, will be similar enough to the mammalian receptor to be cross-reactive with these antibodies. Preliminary dose-response effects with several PCB congeners (Gooch et al., submitted; Appendix I.) indicate that a fish $A h$ receptor might have different ligand-binding properties - that is, it may not show the same relative binding affinity for planar and "mixed-type" PCB congeners that mammals do. In addition, if the 5' noncoding region of the teleost P450IA1 gene were known, it would be easy to identify possible DREs, enhancers and receptor binding sites. The possible role of the carcinogen binding protein, which is about as abundant in scup as in mouse cytosol (Barton and Marletta, 88), should also be further examined.

It should be clear that a number of questions remain about the mechanisms underlying the induction of MFO activities in teleosts in response to foriegn compounds. A variety of findings, from correlations of temporal changes in protein and catalytic specific activity to inhibition of a subset of P-450-type reactions by antibodies recognizing but a single P-450 isozyme, have established that $\mathrm{P}-450 \mathrm{E}$ is in fact the major teleost BNF- (PAH-) inducible EROD and AHH catalyst. The prolonged induction response observed is due to the persistence of the $\mathrm{P}-450 \mathrm{E}$ protein, which has been newly synthesized following exposure to the xenobiotic. P-450E mRNA levels increase prior to increases in protein or activity, suggesting that transcriptional enhancement plays a role in induction. Transcription rates must be measured before this hypothesis can be confirmed. In addition, it is still not firmly established that an $A h$ receptor-like molecule plays a role in teleost $\mathrm{P}-450 \mathrm{E}$ induction. Further characterization of the receptor, its 
ligand-binding properties, and the putative receptor/ligand binding sites on the P450IA1 DNA should shed light on this question.

P-450E mRNA peaks within one or two days and declines rapidly to control levels, while P-450E protein and catalytic activity remain elevated for at least 20 days. This suggests that $\mathrm{P}-450 \mathrm{E}$ protein has a relatively long half-life, in contrast to the rapid induction and loss of activity (and protein) seen in mammals treated with the same inducing chemicals. Results of a dual label turnover study are not totally clear. While a portion of the P-450E apoprotein appears to turn over fairly rapidly, there may be a more stable sub-population as well. The heme moiety appears to have a longer half-life than the rapidly degraded P-450E apoprotein, but incorporation of "old" heme into "new" apoprotein, or heme switching, was not addressed. These results indicate that the method of immunoprecipitation of labeled P-450E can be employed to more closely examine turnover questions. 
196 


\section{APPENDIX}

\section{Induction of P-450E by PCB Congeners}

Our laboratory group has been interested for some time in the capacity of environmental contaminants to induce teleost P-450E (P450IA1). Most of our work, including my investigation of the mechanisms of regulation of P-450E, has focused on PAH-type compounds. Polychlorinated biphenyls (PCBs) are another dominant class of environmental contaminants. It has been well established that PCB mixtures, such as Aroclor 1254, can induce teleost as well as mammalian MFOs (Melancon et al., 81; Melancon and Lech, 83; Ankley et al., 86). Much less is known about which of the myriad congeners are the active inducing agents. To address this question, scup were treated with several individual PCB congeners (Figure A1), which were chosen for their dominance in environmental residues and their ability to induce mammalian P-450 isozymes. The following characteristics were analyzed in livers of scup sacrificed six days after i.p. treatment: P-450E mRNA levels, P-450E protein levels, and EROD activity. mRNA was measured by the indirect method of in vitro translationimmunoprecipitation (Chapter 3), protein was measured by immunoblotting with MAb 1-12-3 (Chapter 2), and EROD activity was measured spectrophotometrically according to Klotz et al. (84).

Congener 77 (3,4,3',4'-tetrachlorobiphenyl [TCB]), a strong inducer of mammalian P-450IA1, was the only PCB congener tested to elicit a significant response in scup hepatic tissue. (Higher doses of the other congeners may be tested in future studies for response.) Surprisingly, this TCB caused the strongest EROD activity increase at the lowest dose used $(0.1 \mathrm{mg} / \mathrm{kg})$. I performed 


\section{PCB Congeners}

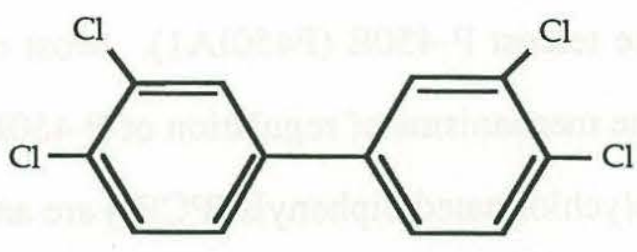

3, 3',4, 4'-TCB

Congener 77

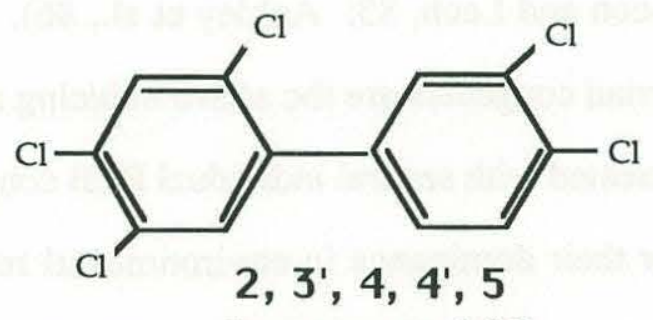

Congener 118

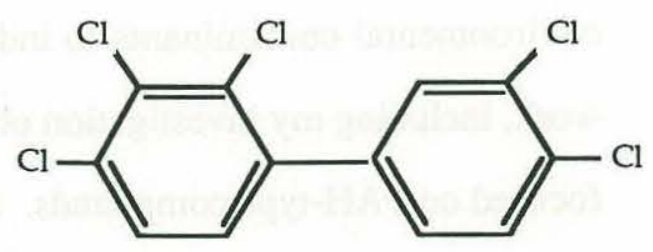

$2,3,3 ', 4,4^{\prime}$

Congener 105

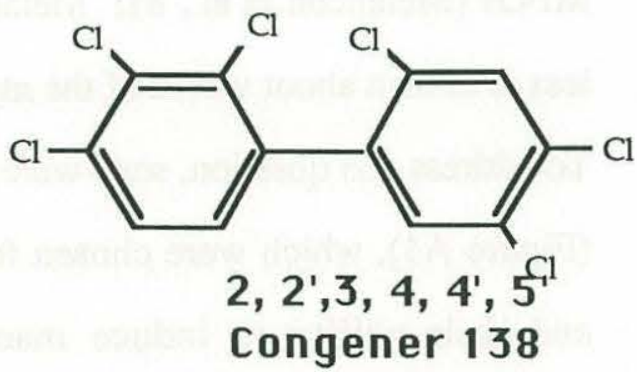

Congener 138

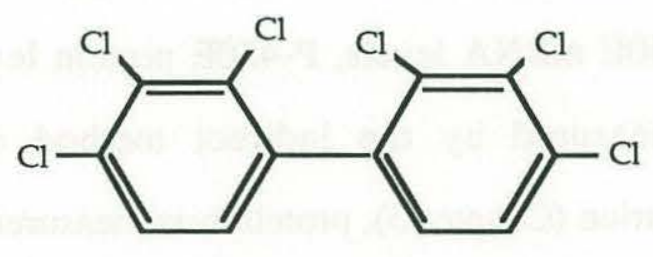

$2,2^{\prime}, 3,3 ', 4,4^{\prime}$

Congener 128

Figure A1. PCB Congeners.

Congeners were tested for their ability to induce scup P-450E mRNA levels, P-450E protein levels, and EROD activity levels. 
in vitro translation/immunoprecipitation assays as described in Chapter 3 to determine whether TCB elicited a P-450E mRNA increase at each dose. At Day 6, the only time examined, all doses of TCB resulted in a marked increase in P-450E mRNA to similar intensities (Figure A2). Although immunodetectable P-450E protein content was highest at the low dose, it did not decline to the same degree as did EROD activity at higher doses of TCB.

It is possible that, given the high levels of P-450E mRNA at each TCB dose, about the same amount of $\mathrm{P}-450 \mathrm{E}$ protein is synthesized in these animals. The decline in immunodetectable $\mathrm{P}-450 \mathrm{E}$ protein at higher doses may be due to increased destabilization and degradation of the protein at higher concentration of TCB. Preliminary in vitro experiments suggest that the TCB may be acting as a competitive inhibitor of the P-450E-catalyzed EROD activity. Such a mechanism is not unprecedented: in rats, the P-450d inducers isosafrole and $3,4,5,3^{\prime}, 4^{\prime}, 5^{\prime}-$ HCB bind to the isozyme and inhibit its normal activities (Voorman and Aust, 88). (It is also possible that bound TCB could block the binding of MAb 1-12-3 to the antigen and cause an underestimate of the P-450E protein content.)

The "positive control" BNF dosage elicited P-450E mRNA levels above the corn oil control levels, but distinctly lower than the TCB-induced RNA levels (Figure A2). (Densitometric analysis of RNA from congener 118-treated scup resulted in P-450E mRNA levels between the very low control and the faint BNF band.) Based on the results obtained with Fundulus - particularly given that the temperature of the scup experiment was elevated compared to that of the Fundulus experiments $\left(20^{\circ} \mathrm{C}\right.$ vs. $\left.14-16^{\circ} \mathrm{C}\right)$ - the $\mathrm{BNF}$ value probably represents a submaximal P-450E mRNA level. BNF-inducible mRNA levels presumably peaked prior to six days and then declined rapidly (compare Figure 4-8), while TCB-induced levels may have remained elevated much longer. 
Figure A2. Immunoprecipitated translation products from PCB experiment. Scup RNA was isolated, translated in the presence of $\left[{ }^{3} \mathrm{H}\right]$-leucine, and immunoprecipitated with a non-immune antibody followed by PAb 119 (see Chapter 3, Materials and Methods, for details). Congener identification and dosage used is indicated below each lane on the fluorograph. $\mathrm{CON}=$ corn oil-treated controls. 
(Figure A-2)
A B
C D E
F
G H

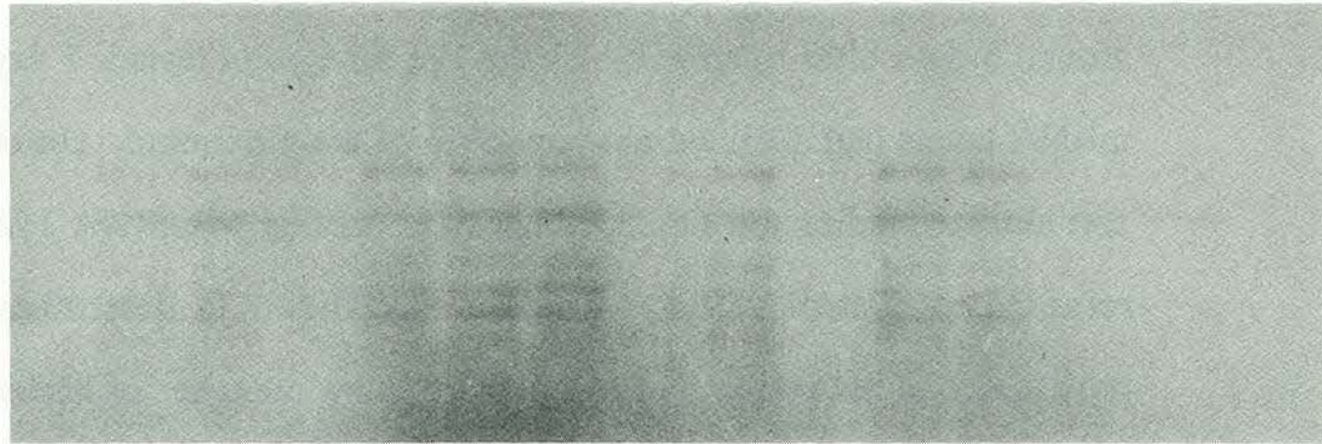

Congener DOSE $(\mathrm{mg} / \mathrm{kg})$

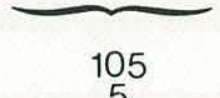

5

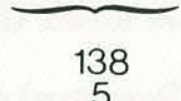

138

1

5

$\begin{array}{lllllll}\text { I } & \text { J } & \text { K } & \text { L } & M & \text { N } & \text { O }\end{array}$

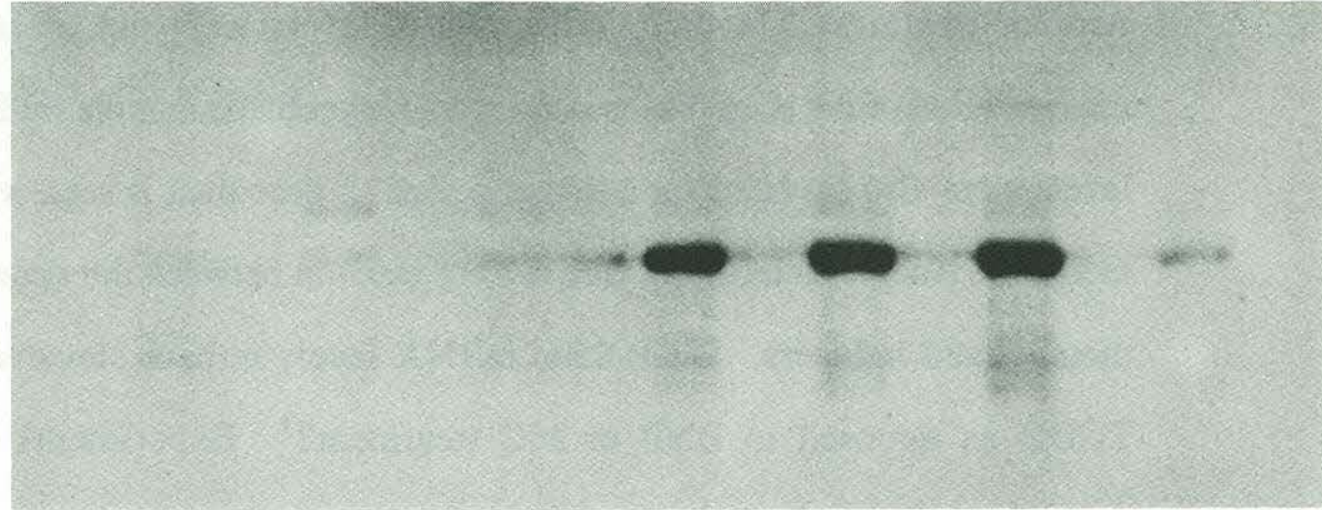

Congener

DOSE $(\mathrm{mg} / \mathrm{kg})$
CON

118
1

$\begin{array}{cc}118 & 77 \\ 5 & 1\end{array}$

77
5

77

10

$B N F$

20 
In the presence of some PCB congeners, both mammalian P-450c mRNA and protein levels achieve a maximum after longer intervals than is seen with PAH-type inducers such as BNF (compare discussion below with Discussion, Chapters 3 and 4). Yeowell et al. (88) followed the induction response in rats after treatment with $50 \mathrm{mg} / \mathrm{kg}$ congener $169\left(3,4,5,3^{\prime}, 4^{\prime}, 5^{\prime}-\right.$ $\mathrm{HCB}$ ). P-450c mRNA peaked at Day 3, and protein levels achieved a maximum at around 5 days after treatment. By the last time point tested, 7 days, the P-450c mRNA levels had declined to about $50 \%$ of the maximum. Unfortunately, this and similar studies did not document the decline of mRNA levels until they returned to control values. Thus, it is difficult to determine whether the presistence of the protein is dependent upon maintenance of higher-than-control mRNA levels (i.e., P-450c mRNAs may have plateaued at $50 \%$ maximal values for a few days) or upon some other mechanism.. Parkinson et al. (83a) found that P-450c protein was induced to an elevated steady state level for about 17 days by Aroclor treatment. In that study, mRNA levels were not measured. If my interpretation of the scup results is correct, it is probable that the rat P-450c mRNA levels were also elevated for a longer period of time than is seen with fast-acting inducers. Another interesting area is a comparison between the slowly and rapidly metabolized inducers. Do P-450c mRNA levels remain elevated longer after TCDD as opposed to BNF or MC treatment? ${ }^{1}$ Experiments with 2,3,7,8tetrachlorodibenzofuran in this laboratory have indicated a longer scup P-450E protein induction response to the furan compared to BNF or other PAH-type compounds; P-450E mRNA levels have yet to be examined (M.E. Hahn, unpublished observations).

These results provide a caveat for those seeking a "quick fix" to the questions of suitable environmental biomonitors. The scup work was part of a 
collaborative effort with several members of the laboratory, and is described in detail in "Effects of ortho and non-ortho substituted polychlorinated biphenyl congeners on the hepatic monooxygenase system in scup (Stenotomus chrysops)," an article undergoing review in Toxicology and Applied Pharmacology (Gooch et a1.).

\section{Scup P-450E mRNA Induction}

Although the cDNA pfP ${ }_{1} 450-3^{\prime}$ prepared by Heilmann et al. (88) was tested for cross-reactivity with genomic DNA from three teleost species and RNA from Fundulus (Chapter 4), the research described in Chapters 1 through 5 does not further evaluate the properties of this cDNA. Subsequent use of this probe will center around the measurement of scup and other teleost P-450E mRNA levels. Thus, I examined scup P-450E mRNA levels in animals at two times following treatment with $20 \mathrm{mg} / \mathrm{kg} \mathrm{BNF}$. The hepatic microsomal MFO parameters (values courtesy of Bruce Woodin, unpublished observations) are shown in Figure A3. EROD activity (expressed on a per mg microsomal protein or on a per nmol P-450 basis) is above control levels by Day 2 and further elevated by Day 3. The same trend is evident for immunodetectable P-450E protein.

Northern blots of total scup RNA were carried out as described in Chapter 4. The autoradiogram indicated striking differences between the control and the BNF-treated animals (scan results, Figure A3). Control values were low but detectable (c1 not detectable and not calculated in the results). Day 2 RNA showed the strongest signal; Day 3 values were still quite high. The cDNA pfP1450-3' thus hybridizes specifically to a single band in scup RNA, a band which is induced by BNF treatment. Although the numbers of animals analyzed in 
this experiment is small, it seems apparent that although EROD activity and P-450E protein content have the highest values at Day 3, the P-450E mRNA levels peaked at Day 2. Thus, the results of this preliminary experiment are consistent with the temporal pattern observed for Fundulus increases: mRNA levels appear to reach their maximum prior to increases in P-450E protein or activity levels. The low level of scup P-450E mRNA seen 6 days after BNF treatment (Appendix I.) suggests that by this time, scup mRNA levels have declined significantly. Again, this is consistent with the results obtained with Fundulus experiments. 
Figure A3

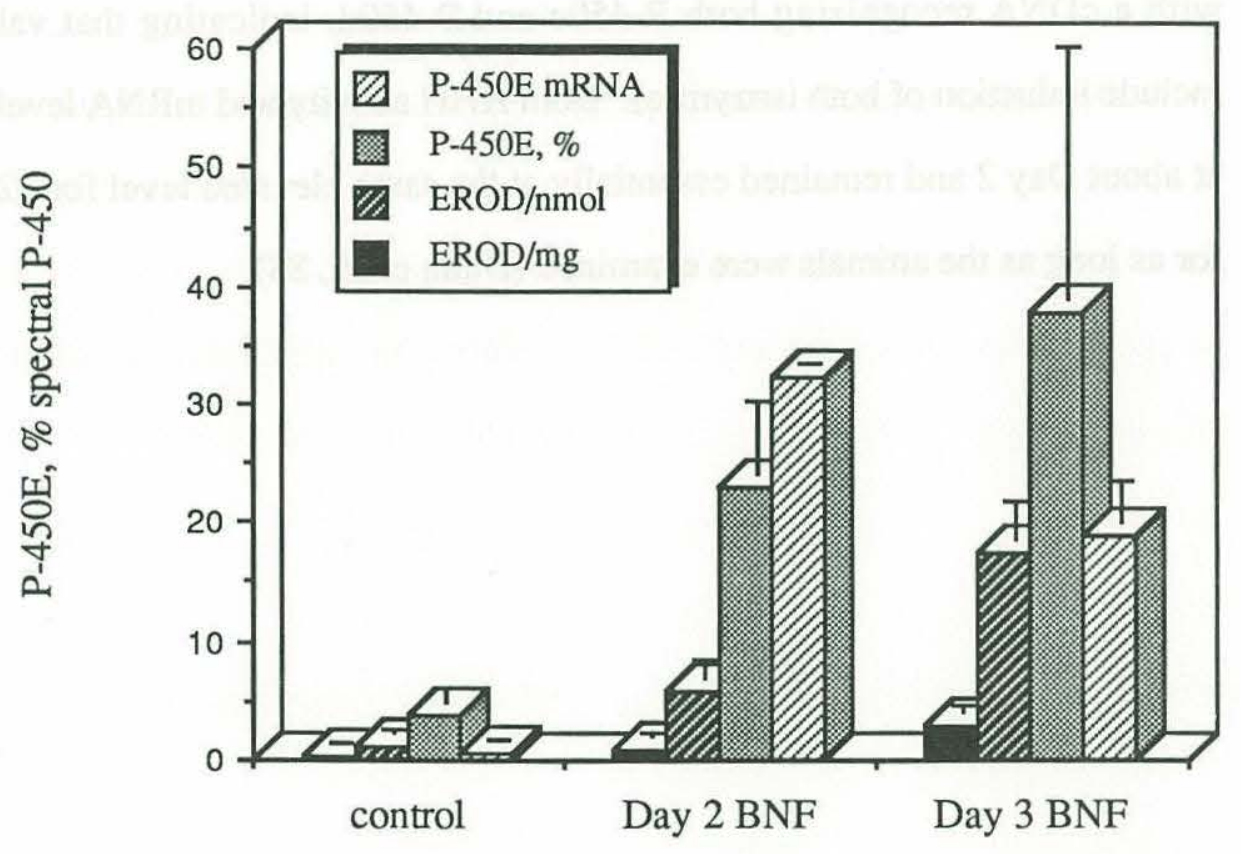

Figure A3. Scup MFO parameters and P-450E mRNA levels after treatment with BNF.

Scup were treated with $20 \mathrm{mg} / \mathrm{kg}$ BNF and sacrificed at the times indicated. Catalytic activities and immunodetectable P-450E protein were determined as before (see text). P-450E mRNA values were determined by hybridization to a [32P]-labeled trout P450IA1 cDNA (Heilmann et al., 88). mRNA values were transformed to fit onto the scale of the bar graph. 
${ }^{1}$ A recent article reports that 10 or $100 \mathrm{ug} / \mathrm{kg}$ TCDD treatment causes prolonged elevation of rat P-450c mRNA (total RNA measured in dot blots by hybridization with a cDNA recognizing both P-450c and P-450d, indicating that values may include induction of both isozymes). Both AHH activity and mRNA levels peaked at about Day 2 and remained essentially at the same elevated level for 22 days, or for as long as the animals were examined (Dunn et al., 88). 


\section{BIBLIOGRAPHY}

Adesnik, M., and M. Atchison. 1986. Genes for cytochrome P-450 and their regulation. CRC Critical Reviews in Biochemistry 19: 247-303.

Ahokas, J.T., H. Saarni, D.W. Nebert, and 0. Pelkonen. 1979. The in vitro metabolism and covalent binding of benzo[a]pyrene to DNA catalyzed by trout liver microsomes. Chem. Biol. Inter. 25: 103-111.

Alberts, B., D. Bray, J. Lewis, M. Raff, K. Roberts, and J.D. Watson, eds. 1983. The Cell Nucleus. in: Molecular Biology of the Cell. Garland Publishing, Inc., N.Y. pp. 385-482.

American Zoologist. (various authors) 1986. The biology of Fundulus heteroclitus. Vol 26: 107-288.

Amersham Corporation. Labeling of DNA with ${ }^{32} \mathrm{P}$ by nick translation. (Information Booklet) pp. 1-15.

Andersson, T., M. Pesonen, C. Johansson. 1985. Differential induction of cytochrome P-450-dependent monooxygenase, epoxide hydrolase, glutathione transferase, and UDP glucuronyltransferase activities in the liver of the rainbow trout by B-naphthoflavone or Clophen A50. Biochem. Pharm. 34: 3309-3314.

Ankley, G.T., V.S. Blazer, R.E. Reinert, and M. Agosin. 1986. Effects of Aroclor 1254 on cytochrome P-450-dependent monooxygenase, glutathione S-transferase, and UDP-glucuronosyltransferase activities in channel catfish liver. Aquatic Tox. 9: 91-103.

Aoyama, Y., Y. Yoshida, Y. Sonoda, and Y. Sato. 1987. Metabolism of 32-hydroxy-24,25-dihydrolanosterol by purified cytochrome P-450 14DM from yeast. J. biol. Chem. 262: 1239-1243.

Arias, I.M., D. Doyle, and R.T. Schimke. 1969. Studies on the synthesis and degradation of proteins of the endoplasmic reticulum. J. biol. Chem. 244: 33033315.

Arnold, P.S., B. Tierney, and R.C. Garner. 1988. Rat liver immunoultrastructural localization of the specific (4-5S) 3-methylcholanthrene-binding protein: evidence for its involvement as a receptor protein in cytochrome P-4501A1 induction. Carcinogenesis 9: 21-28.

Arnold, P.S., R.C. Garner, and B.Tierney. 1987. Purification and photoaffinity labelling of a rat cytosolic binding protein specific for 3-methylcholanthrene. Biochem. J. 242: 375-381.

Bandiera, S., T. Sawyer, M.A. Campbell, T. Fujita, and S. Safe. 1983. Competetive binding to the cytosolic 2,3,7,8-TCDD receptor: effects of structure on the affinities of substituted halogenated biphenyls - a QSAR approach. Biochem. Pharm. 32: 3803-3813. 
Barton, H.A., and M.A. Marletta. 1988. Kinetic and immunochemical studies of a receptor-like protein that binds aromatic hydrocarbons. J. biol. Chem. 263: 5825-5832.

Baulieu, E.-E. 1987. Steroid hormone antagonists at the receptor level: a role for the heat-shock protein MW 90,000 (hsp 90). J. Cell. Biochem. 35: 161-174.

Bend, J.R., R.J. Pohl, and J.R. Fouts. 1973. Further studies of the microsomal mixed-function oxidase system of the little skate, Raja erinacea, including its response to some xenobiotics. Bull. Mt. Des. Isl. Biol. Lab. 13: 9-13.

Berlin, C.M., and R.T. Schimke. 1965. Influence of turnover rates on the responses of enzymes to cortisone. Mol. Pharm. 1: 149-156.

Bhat, G.J., and G. Padmanaban. 1988. Heme is a positive regulator of cytochrome P-450 gene transcription. Arch. Biochem. Biophys. 264: 584-590.

Binder, R., J.J. Stegeman, and J. Lech. 1985. Induction of cytochrome P-450dependent monooxygenase systems in embryos and eleutheroembryos of the killifish Fundulus heteroclitus. Chem. Biol. Interactions 55: 185-202.

Binder, R.L., and J.J Stegeman. 1980. Induction of aryl hydrocarbon hydroxylase activity in embryos of an estuarine fish. Biochem. Pharm. 29: 949951.

Binder, R.L., and J.J. Stegeman. 1984. Microsomal electron transport and xenobiotic monooxygenase activities during the embryonic period of development in the killifish Fundulus heteroclitus. Toxicol. Applied Pharm. 73: 432-443.

Black, S.D., and M.J. Coon. 1986. Comparative structures of P-450 cytochromes. in: Cytochrome P-450: Structure, Mechanism, and Biochemistry. P.R. Ortiz de Montellano, Plenum Press, NY. pp. 161-216.

Blank, J.A., A.N. Tucker, J. Sweatlock, T.A. Gasiewicz, and M.I. Luster. 1987. Alpha-naphthoflavone antagonism of 2,3,7,8-tetrachlorodibenzo-p-dioxininduced murine lymphocyte ethoxyresorufin $\mathrm{O}$-deethylase activity and immunosuppression. Mol. Pharm. 32: 168-172.

Bonner, W.M., and R.A. Laskey. 1974. A film detection method for tritiumlabelled proteins and nucleic acids in polyacrylamide gels. Eur. J. Biochem. 46: 83-88.

Boobis, A.R., D.W. Nebert, and J.S. Felton. 1977. Comparison of ß-naphthoflavone and 3-methylcholanthrene as inducers of hepatic cytochrome(s) P-448 and aryl hydrocarbon (benzo[a]pyrene) hydroxylase activity. Mol. Pharm. 13: 259-68.

Bresnick, E., M. Brosseau, W. Levin, L. Reik, D.E. Ryan, and P.E. Thomas. 1981. Administration of 3-methylcholanthrene to rats increases the specific hybridizable mRNA coding for P-450c. PNAS 78: 4083-4087. 
Burns, K.A. 1976. Microsomal MFO in an estuarine fish, Fundulus heteroclitus, and their induction as a result of environmental contamination. Comp. Biochem. Physiol. 53B: 443-446.

Cheng, K.-C., H.V. Gelboin, B.-J. Song, S.S. Park, and F.K. Friedman. 1984. Detection and purification of cytochromes P-450 in animal tissues with monoclonal antibodies. J. biol. Chem. 259: 12279-12284.

Chiou, C.T. 1985. Partition coefficients of organic compounds in lipid-water systems and correlations with fish bioconcentration factors. Environ. Sci. Tech. 19: $57-62$.

Chirgwin, J.M., A.E. Przybyla, R.J. MacDonald, and W.J. Rutter. 1979. Isolation of biologically active ribonucleic acid from sources enriched in ribonuclease. Biochem. 18: 5294-5299.

Collins, S., and M.A. Marletta. 1984. Carcinogen-binding proteins. High affinity binding sites for benzo[a]pyrene in mouse liver distinct from the $A h$ receptor. Mol. Pharm. 26: 353-359.

Collins, S., and M.A. Marletta. 1986. Purification of a benzo[a]pyrene binding protein by affinity chromatography and photoaffinity labeling. Biochem. 25: $4322-4329$.

Conney, A.H. 1967. Pharmacological implications of microsomal induction. Pharm. Rev. 19: 317-366.

Crouse, J., and D. Amorese. 1987. Ethanol precipitation: ammonium acetate as an alternative to sodium acetate. Focus 9:2, pp. 3-5.

DeMarco, G.J. and G.D. McCoy. 1985. Involvement of cytochrome b5 in the hepatic microsomal metabolism of benzo[a]pyrene. Biochem. Biophys. Res. Comm. 128: 621-627.

Denis, M., S. Cuthill, A.-C. Wikström, L. Poellinger, and J.-A. Gustafsson. 1988. Association of the dioxin receptor with the $M_{r} 90,000$ heat shock protein: a structural kinship with the glucocorticoid receptor. Biochem. Biophys. Res. Comm. 155: 801-807.

Denison, M.S., and C.F. Wilkinson. 1985. Identification of the $A h$ receptor in selected mammalian species and induction of aryl hydrocarbon hydroxylase. Eur. J. Biochem. 147: 429-435.

Denison, M.S., J.M. Fisher, and J.P. Whitlock, Jr. 1988. Inducible, receptordependent protein-DNA interactions at a dioxin-responsive transcriptional enhancer. PNAS (USA) 85: 2528-2532.

Denison, M.S., J.W. Hamilton, and C.F. Wilkinson. 1985. Comparative studies of aryl hydrocarbon hydroxylase and the $A h$ receptor in nonmammalian species. Comp. Biochem. Physiol. 80C: 319-324. 
Denison, M.S., L.M. Vella, and A.B. Okey. 1986. Hepatic $A h$ receptor for 2,3,7,8-tetrachlorodibenzo-p-dioxin: partial stabilization by molybdate. J. biol. Chem. 261: 10189-10195.

Druyan, R., B. DeBernard, and M. Rabinowitz. 1969. Turnover of cytochromes labeled with delta-aminolevulinic acid- ${ }^{3} \mathrm{H}$ in rat liver. J. biol. Chem. 244: 58745878.

Dunn, T.J., R. Lindahl, H.C. Pitot. 1988. Differential gene expression in response to 2,3,7,8-tetrachlorodibenzo-p-dioxin (TCDD). Noncoordinate regulation of a TCDD-induced aldehyde dehydrogenase and cytochrome P-450c in the rat. J. biol. Chem. 263: 10878-10886.

Durrin, L.K. and J.P. Whitlock, Jr. 1987. In situ protein-DNA interactions at a dioxin-responsive enhancer associated with the cytochrome $\mathrm{P}_{1} 450$ gene. Mol. Cell. Biol. 7: 3008-3011.

Dwarki, V.J., V.N.K. Francis, G.J. Bhat, and G. Padmanaban. 1987. Regulation of cytochrome P-450 messenger RNA and apoprotein levels by heme. J. biol. Chem. 262: 16958-16962.

Elskus, A.A., and J.J. Stegeman. 1989. Further consideration of phenobarbital effects on cytochrome P-450 activity in the killifish, Fundulus heteroclitus. Comp. Biochem. Physiol., in press

Elskus, A.A., and J.J. Stegeman. Induced cytochrome P-450 in Fundulus heteroclitus associated with environmental contamination by polychlorinated biphenyls and polynuclear aromatic hydrocarbon. Submitted.

Fagan, J., J. Pastewka, F. Guengerich, and H. Gelboin. 1983. Multiple cytochromes P-450 are translated from multiple messenger ribonucleic acids. Biochem. 22: 1927-1934.

Fagan, J.B., J. V. Pastewka, S.C. Chalberg, E. Gozukara, F.P. Guengerich, and H.V. Gelboin. 1986. Noncoordinate regulation of the mRNAs encoding cytochromes P-450 BNF/MC-3 and ISF/BNF-G. Arch. Biochem. Biophys. 244: 261-272.

Fang, L.-S. 1987. Study on the heme catabolism of fish. Comp. Biochem. Physiol. 88B: 667-673.

Fauconneau, B., and M. Arnal. 1985a. In vivo protein synthesis in different tissues and the whole body of rainbow trout (Salmo gairdnerii R.). Influence of environmental temperature. Comp. Biochem. Physiol. 82A: 179-187.

Fauconneau, B., and M. Arnal. 1985b. Leucine metabolism in trout (Salmo gairdnerii R.). Influence of temperature. Comp. Biochem. Physiol. 82A: 435445.

Fernandez, J., O. Gonzalez, M. Martin, and M.R. Amil. 1987. Trout (Salmo gairdneri R.) liver 5-aminolevulinate synthetase: subcellular distribution and properties. Comp. Biochem. Physiol. 86B: 245-249. 
Fitch, W.M. 1970. Distinguishing homologous from analogous proteins. Systematic Zoology 19: 99-113.

Forster, R.P., and L. Goldstein. 1969. Formation of excretory products. in Fish Physiology (W.S. Hoar and D.J. Randall, ed.) Vol I, Academic Press, NY. pp. 313-350.

Förlin, L. 1980. Effects of Clophen A50, 3-methylcholanthrene, pregnenolone 16-alpha carbonitrile and phenobarbital on the hepatic microsomal cytochrome P-450-dependent monooxygenase system in rainbow trout, Salmo gairdneri, of different sex and age. Toxicol. Applied Pharm. 54: 420-430.

Gaastra, W., and P.L. Jorgensen. 1984. The extraction and isolation of DNA from gels. in Methods of Molecular Biology (J.M. Walker, ed.) Vol. 2, pp. 6776, Humana Press, Clifton, NJ.

Gan, J.C., and H. Jeffay. 1967. Origins and metabolism of the intracellular amino acid pools in rat liver and muscle. Biochim. Biophys. Acta 148: 448-459.

Garlick, P.J., M.A. McNurlan, and V.R. Preedy. 1980. A rapid and convenient technique for measuring the rate of protein synthesis in tissues by injection of $\left[{ }^{3} \mathrm{H}\right]$ phenylanaline. Biochem. J. 192: 719-723.

Gasiewicz, T.A., and G. Rucci. 1984. Cytosolic receptor for 2,3,7,8tetrachlorodibenzo-p-dioxin. Evidence for a homologous nature among various mammalian species. Mol. Pharm. 26: 90-98.

Gasiewicz, T.A., and R.A. Neal. 1982. The examination and quantitation of tissue cytosolic receptors for 2,3,7,8-tetrachlorodibenzo-p-dioxin using hydroxylapatite. Anal. Biochem. 124: 1-11.

Gerard, G.F., and K. Miller. 1986. Comparison of glyoxal and formaldehyde gels for sizing rRNAs. Focus 8:3, pp. 5-6.

Gingold, E.B. 1984. The use of restriction endonucleases. in Methods of Molecular Biology (J.M. Walker, ed.) Vol. 2, Humana Press, Clifton, NJ. pp. 217-223.

Goddard, K.A., R.J. Schultz, and J.J. Stegeman. 1987. Uptake, toxicity, and distribution of benzo[a]pyrene and monooxygenase induction in the topminnows Poeciliopsis monacha and Poeciliopsis lucida. Drug Metab. Dispos. 15: 449-455.

Goksøyr, A. 1985. Purification of hepatic microsomal cytochromes P-450 from ß-naphthoflavone-treated Atlantic cod (Gadus morhua), a marine teleost fish. Biochim. Biophys. Acta 840: 409-417.

Goksøyr, A. 1986. Regioselective metabolism of phenanthrene in Atlantic cod (Gadus morhua): studies on the effects of monooxygenase inducers and role of cytochromes P-450. Chem. Biol. Inter. 60: 247-263. 
Goksøyr, A., T. Andersson, L. Förlin, J. Stenersen, E.A. Snowberger, B.R. Woodin, and J.J. Stegeman. 1988. Xenobiotic and steroid metabolism in adult and foetal piked (Minke) whales (Balaenoptera acutorostrata). Marine Environ. Res. 24: 9-13.

Gonzalez, F.J., R.H. Tukey, and D.W. Nebert. 1984. Structural gene products of the $A h$ locus - transcriptional regulation of cytochrome $\mathrm{P}_{1} 450$ and $\mathrm{P}_{3} 450$ mRNA levels by 3-methylcholanthrene. Mol. Pharm. 26: 117-121.

Gooch, J.W., A.A. Elskus, P.J. Kloepper-Sams, M.E. Hahn, and J.J. Stegeman. Effects of ortho and non-ortho substituted polychlorinated biphenyl congeners on the hepatic monooxygenase system in scup (Stenotomus chrysops). Toxicol. Applied Pharm., submitted.

Gooch, J.W., and F. Matsumura. 1983. Characteristics of the hepatic monooxygenase system of the goldfish (Carassius auratus) and its induction with B-naphthoflavone. Toxicol. Applied Pharm. 68: 380-391.

Gray, E.S. 1988. Sexual patterns of monooxygenase function in the liver of marine teleosts and the regulation of activity by estradiol. Ph.D. Thesis. MIT/WHOI.

Greenlee, W.F., and A. Poland. 1979. Nuclear uptake of 2,3,7,8tetrachlorodibenzo-p-dioxin in C57BL/6J and DBA/2J mice - role of the hepatic cytosolic receptor protein. J. biol. Chem. 254: 9814-9821.

Griffith, R. 1974. Environmental and salinity tolerance in the genus Fundulus. Copeia 2: 319-331.

Guengerich, F.P., and T.L. MacDonald. 1984. Chemical mechanisms of catalysis by cytochromes P-450: a unified view. Acc. Chem. Res. 17: 9-16.

Haasch, M., P. Weijksnora, J.J. Lech, and J.J. Stegeman. Use of cloned rainbow trout liver $\mathrm{P}_{1} 450$ complementary DNA as a potential environmental monitor. submitted.

Hamilton, J.W., W.J. Bement, P.R. Sinclair, J.F. Sinclair, and K.E. Wetterhahn. 1988. Expression of 5-aminolaevulinate synthase and cytochrome P-450 mRNAs in chicken embryo hepatocytes in vivo and in culture. Biochem. J. 255: 267-275.

Hansson, T., and J.-A. Gustafsson. 1981. Sex differences in the hepatic metabolism of 4-androstene-3,17-dione in rainbow trout, Salmo gairdneri. Gen. Comp. Endocrinol. 49: 490-494.

Hardwick, J.P., P. Linko, and J.A. Goldstein. 1985. Dose response for induction of two cytochrome P-450 isozymes and their mRNAs by $3,4,5,3^{\prime}, 4^{\prime}, 5^{\prime}-$ hexachlorobiphenyl indicating coordinate regulation in rat liver. Mol. Pharm. 27: 676-682. 
Heilmann, L.J., Y.-Y. Sheen, S.W. Bigelow, and D.W. Nebert. 1988. Trout P450IA1: cDNA and deduced protein sequence, expression in liver, and evolutionary significance. DNA 7: 379-387.

Hewish, D.R., and L.A. Burgoyne. 1973a. The calcium dependent endonuclease activity of isolated nuclear preparations. Biochem. Biophys. Res. Comm. 52: 475-481.

Hewish, D.R., and L.A. Burgoyne. 1973b. Chromatin sub-structure. The digestion of chromatin DNA at regularly spaced sites by a nuclear deoxyribonuclease. Biochem. Biophys. Res. Comm. 52: 504-510.

Hobbs, A.A., L.A. Mattschoss, B.K. May, K.E. Williams, and W.H. Elliot. 1986. The cDNA and protein sequence of a phenobarbital-induced chicken cytochrome P-450. J. biol. Chem. 261: 9444-9449.

Houser, W.H., C.K. Cunningham, R.N. Hines, W.I. Schaeffer, and E. Bresnick. 1987. Interaction of the 4 S polycyclic aromatic hydrocarbon-binding protein with the cytochrome P-450c gene. Arch. Biochem. Biophys. 259: 215223.

Houser, W.H., R.N. Hines, and E. Bresnick. 1985. Implication of the "4S" polycyclic aromatic hydrocarbon binding protein in the transregulation of rat cytochrome P-450c expression. Biochem. 24: 7839-7845.

Ish-Horowicz, D., and J.F. Burke. 1981. Rapid and efficient cosmid vector cloning. Nucleic Acids Res. 9: 2989-2998.

Israel, D., and J.P. Whitlock, Jr. 1984. Regulation of cytochrome $\mathrm{P}_{1} 450$ gene transcription by 2,3,7,8-tetrachlorodibenzo-p-dioxin in wild type and variant mouse hepatoma cells. J. biol. Chem. 259: 5400-5402.

James, M.O., and J. Bend. 1980. PAH induction of cytochrome P-450dependent MFO in marine fish. Toxicol. Applied Pharm. 54: 117-133.

John, M.E., M.C. John, E.R. Simpson, and M.R. Waterman. 1985. Regulation of cytochrome P-450 ll- $\beta$ gene expression by adrenocorticotropin. J. biol. Chem. 260: $5760-5767$.

Jones, P.B.C., D.R. Galeazzi, J.M. Fisher, and J.P. Whitlock, Jr. 1985. Control of cytochrome $\mathrm{P}_{1} 450$ gene expression by dioxin. Sci. 227: 1499-1502.

Jones, P.B.C., L.K. Durrin, D.R. Galeazzi, and J.P. Whitlock, Jr. 1986. Control of cytochrome $\mathrm{P}_{1} 450$ gene expression: analysis of a dioxin-responsive enhancer system. PNAS (USA) 83: 2802-2806.

Junghahn, I., and K. Jürss. 1988. Effects of feeding and salinity on protein synthesis in the white epaxial muscle of the rainbow trout (Salmo gairdneri Richardson). Comp. Biochem. Physiol. 89C: 329-333.

Kato, R., W. Jondorf, L. Loeb, T. Ben, and H.V. Gelboin. 1966. Studies on the mechanism of drug-induced microsomal enzyme activities. V. PB stimulation 
of endogenous messenger RNA and polyuridylic acid-directed L-[ $\left.{ }^{14} \mathrm{C}\right]-$ phenylalanine incorporation. Mol. Pharm. 2: 171-186.

Kimura, S., F.J. Gonzalez, and D.W. Nebert. 1986. Tissue-specific expression of the mouse dioxin-inducible $\mathrm{P}_{1} 450$ and $\mathrm{P}_{3} 450$ genes: diffferential transcriptional activation and mRNA stability in liver and extrahepatic tissues. Mol. Cell. Biol. 6: 1471-1477.

Kimura, S., J.C. Donovan, D.W. Nebert. 1987. Expression of the mouse $\mathrm{P}_{1} 450$ gene during differentiation without foreign chemical stimulation. J. Exp. Path. 3: 61-74.

Kloepper-Sams, P.J., S.S. Park, H.V. Gelboin, and J.J. Stegeman. 1987. Specificity and cross-reactivity of monoclonal and polyclonal antibodies against cytochrome P-450E of the marine fish scup. Arch. Biochem. Biophys. 253: 268278.

Klotz, A.V., J.J. Stegeman, and C. Walsh. 1983. An aryl hydrocarbon hydroxylating cytochrome P-450 form the marine fish Stenotomus chrysops. Arch. Biochem. Biophys. 226: 578-592.

Klotz, A.V., J.J. Stegeman, and C. Walsh. 1984. An alternative 7-ethoxyresorufin O-deethylase activity assay: a continuous visible spectrophotometric method for measurement of cytochrome P-450 monoxygenase activity. Anal. Biochem. 140: 138-145.

Klotz, A.V., J.J. Stegeman, B.R. Woodin, E.A. Snowberger, P.E. Thomas, and C. Walsh. 1986. Cytochrome P-450 isozymes from the marine teleost Stenotomus chrysops: their roles in steroid hydroxylation and the influence of cytochrome b5. Arch. Biochem. Biophys. 249: 326-338.

Leipoldt, M., H.G. Kellner, and S. Stark. 1984. Comparative analysis of ribosomal RNA in various fish and other vertebrate species: hidden breaks and ribosomal function in phylogenetically tetraploid species of Cyprinidae. Comp. Biochem. Physiol. 77B: 769-777.

Levin, W., D. Ryan, R. Kuntzman, and A.H. Conney. 1975. Neonatal imprinting and the turnover of microsomal cytochrome P-450 in rat liver. Mol. Pharm. 11: 190-200.

Lewin, B. 1987. Genes. Third Edition. John Wiley \& Sons, NY. 761 pp.

Lindquist, S. 1986. The heat-shock response. Ann. Rev. Biochem. 55: 11511191.

Lowry, O.H., N.J. Rosebrough, A.L. Farr, R.J. Randall. 1951. Protein measurement with the Folin phenol reagent. J. biol. Chem. 193: 265-275.

Lu, A.Y.H., and S.B. West. 1980. Multiplicity of mammalian microsomal cytochromes P-450. Pharm. Rev. 31: 277-295. 
MacKay, D. 1982. Correlations of bioconcentration factors. Environ. Sci. Tech. 16: 274-278.

MacKee, M.J., A.C. Hendricks, and R.E. Ebel. 1983. Effects of naphthalene on benzo[a]pyrene hydroxylase and cytochrome P-450 in Fundulus heteroclitus. Aquatic Tox. 3: 103-114.

Manchester, D.K., S.K. Gordon, C.L. Golas, E.A. Roberts, and A.B. Okey. 1987. Ah receptor in human placenta: stabilization by molybdate and characterization of binding of 2,3,7,8-tetrachlorodibenzo-p-dioxin, 3methylcholanthrene, and benzo[a]pyrene. Cancer Res. 47: 4861-4868.

Maniatis, T., E.F. Fritsch, and J. Sambrook. 1984. Molecular cloning: a laboratory manual. Cold Spring Harbor Laboratory.

Marks, G.S., S.A. McCluskey, J.E. Mackie, D.S. Riddick, and C.A. James. 1988. Disruption of hepatic heme biosynthesis after interaction of xenobiotics with cytochrome P-450. FASEB J. 2: 2774-2783.

Matocha, M.F., and M.R. Waterman. 1985. Synthesis and processing of mitochondrial steroid hydroxylases. J. biol. Chem. 260: 12259-12265.

May, B.K., I.A. Borthwick, G. Srivastava, B.A. Pirola, and W.H. Elliot. 1986. Control of 5-aminolevulinate synthase in animals. Current Topics in Cell. Reg. 28: 233-262.

McMahon, G., L.J. Huber, M.J. Moore, J.J. Stegeman, and G.N. Wogan. Mutations in c-Ki-ras oncogenes: prevalence in liver disease and neoplasia in winter flounder form Boston Harbor. submitted.

Meier, P.J., R. Gasser, H.-P. Hauri, B. Stieger, and U.A. Meyer. 1984. Biosynthesis of rat liver cytochrome $\mathrm{P}-450$ in mitochondria-associated rough endoplasmic reticulum and in rough microsomes in vivo. J. biol. Chem. 259: 10194-10200.

Melancon, M.J., and J.J. Lech. 1983. Dose-effect relationship for induction of hepatic monooxygenase activity in rainbow trout and carp by Aroclor 1254 . Aquatic Tox. 4: 51-61.

Melancon, M.J., C.R. Elcombe, M.J. Vodicnik, and J.J. Lech. 1981. Induction of cytochromes P-450 and mixed-function oxidase activity by polychlorinated biphenyls and B-naphthoflavone in carp (Cyprinus carpio). Comp. Biochem. Physiol. 69C: 219-226.

Melancon, M.J., D.E. Williams, D.R. Buhler, and J.J. Lech. 1985. Metabolism of 2-methylnapthalene by rat and rainbow trout hepatic microsomes and purified cytochrome P-450. Drug Metab. Dispos. 13: 542-547.

Morgan, E.T., and M.J. Coon. 1984. Effects of cytochrome b5 on cytochrome P-450-catalyzed reactions - studies with mangenese-substituted cytochrome b5. Drug Metab. Dispos. 12: 358-364. 
Muller-Eberhard, U., and S.H. Vincent. 1985. Concepts of heme distribution within hepatocytes. Biochem. Pharm. 34: 719-725.

Nebert, D.W., and F.J. Gonzalez. 1987. P-450 genes. Structure, evolution, and regulation. Ann Rev. Biochem. 56: 945-93.

Nebert, D.W., and N.M Jensen. 1979. The $A h$ locus: genetic regulation of the metabolism of carcinogens, drugs, and other environmental chemicals by cytochrome P-450-mediated monooxygenases. CRC Rev. Biochem. 6: 401-431.

Nebert, D.W., H.J. Eisen, M. Negishi, M.A. Lang, L.M. Hjelmeland, and A. Okey. 1981. Genetic mechanism controlling the induction of polysubstrate monooxygenase (P-450) activities. Ann. Rev. Pharmacol. Toxicol. 21: 431-462.

Nebert, D.W., M. Adesnik, M.J. Coon, R.W. Estabrook, F.J. Gonzalez, F.P. Guengerich, I.C. Gunsalus, E.F. Johnson, B. Kemper, W. Levin, I.R. Phillips, R. Sato, and M.R. Waterman. 1987. The P-450 gene superfamily, recommended nomenclature. DNA 6: 1-11.

Neff, J. 1985. Use of biochemical measurements to detect pollutant-mediated damage to fish. in Aquatic Toxicology and Hazard Assessment: 7th Symposium ASTM STP 854. R.D.Caldwell, R. Purdy, and R.C. Bahner, eds. Amer. Soc. for Testing \& Materials, Philadelphia, PA. pp. 155-183.

Negishi, M., and D.W. Nebert. 1981. Structural gene products of the $A h$ complex. J. biol. Chem. 256: 3085-3091.

Negishi, M., N.M. Jensen, G.S. Garcia, and D.W. Nebert. 1981. Structural gene products of the murine $A h$ complex: differences in ontogenesis and glucosamine incorporation between liver microsomal cytochromes $\mathrm{P}_{1}-450$ and P448 induced by polycyclic aromatic compounds. Eur. J. Biochem. 115: 585594.

Nelson, D.R., and H.W. Strobel. 1987. Evolution of cytochrome P-450 proteins. Mol. Biol. Evol. 4: 572-593.

Nelson, D.R., and H.W. Strobel. 1988. On the membrane topology of vertebrate cytochrome P-450 proteins. J. biol. Chem. 263: 6038-6050.

Nishimoto, M., and U. Varanasi. 1985. Benzo[a]pyrene metabolism and DNA adduct formation mediated by English sole liver enzymes. Biochem. Pharm. 34: 263-268.

Okey, A., and L. Vella. 1984. Elevated binding of 2,3,7,8-tetrachlorodibenzo-pdioxin and 3-methylcholanthrene to the $A h$ receptor in hepatic cytosols from phenobarbital-treated rats and mice. Biochem. Pharm. 33: 531-538.

Okey, A.B., G.P. Body, M.E. Mason, D.W. Nebert, C.J. Forster-Gibson, J. Muncan, and M.J. DuFresne. 1980. Temperature-dependent cytosol-to-nucleus translocation of the $A h$ receptor for 2,3,7,8-tetrachlorodibenzo- $p$-dioxin in continuous cell culture lines. J. biol. Chem. 255: 11415-11422. 
Okey, A.B., G.P. Bondy, M.E. Mason, G.F. Kahl, H.J. Eisen, T.M. Guenthner, and D.W. Nebert. 1979. Regulatory gene product of the $A h$ locus characterization of the cytosolic inducer-receptor complex and evidence for its nuclear translocation. J. biol. Chem. 254: 11636-11648.

Okey, A.B., L.M. Vella, and P.A. Harper. 1988. Ah receptor in mice genetically "nonresponsive" for cytochrome $\mathrm{P}_{1} 450$ induction: characterization in hepatic cytosol of a receptor having reduced affinity for 2,3,7,8-tetraclorodibenzop-dioxin. 6th International Conference on Biochemistry and Biophysics of Cytochrome P-450. Vienna, Austria, pg. 61

Omura, T., and R. Sato. 1964. The carbon monoxide-binding pigment of liver microsomes. J. biol. Chem. 239: 2370-2378.

Ortiz de Montellano, P.R., Ed. 1986. Cytochrome P-450: Structure, mechanism and biochemistry. Plenum Press, NY. $556 \mathrm{pp}$.

Park, S.S., D.J. Waxman, H. Miller, R. Robinson, C. Attisano, F.P. Guengerich, and H.V. Gelboin. 1986b. Preparation and characterization of monoclonal antibodies to pregnenolone 16-alpha-carbonitrile inducible rat liver cytochrome P-450. Biochem. Pharm. 35: 2859-2867.

Park, S.S., H. Miller, A.V. Klotz, P.J. Kloepper-Sams, J.J. Stegeman, and H.V. Gelboin. 1986a. Monoclonal antibodies to liver microsomal cytochrome P-450E of the marine fish Stenotomus chrysops (scup): crossreactivity with 3-methylcholanthrene induced rat cytochrome P-450. Arch. Biochem. Biophys. 249: 339-350.

Parkinson, A., P.E. Thomas, D.E. Ryan, and W. Levin. 1983a. The in vivo turnover of rat liver epoxide hydrolase and both the apoprotein and heme moieties of specific cytochrome P-450 isozymes. Arch. Biochem. Biophys. 225: 216-236.

Parkinson, A., P.E. Thomas, D.E. Ryan, L.M. Reik, S.H. Safe, L.W. Robertson, and W. Levin. 1983b. Differential time course of induction of rat liver microsomal cytochrome P-450 isozymes and epoxide hydrolase by Aroclor 1254. Arch. Biochem. Biophys. 225: 203-215.

Pasco, D.S., K.W. Boyum, S.N. Merchant, S.C. Chalberg, and J.B. Fagan. 1988. Transcriptional and post-transcriptional regulation of the genes encoding cytochromes P-450c and P-450d in vivo and in primary hepatocyte cultures. J. biol. Chem. 263: 8671-8676.

Payne, J.F. 1984. Mixed-function oxygenases in biological monitoring programs: review of potential usage in different phyla of aquatic animals. in Ecotoxicological Testing for the Marine Environment, Vol 1. (G. Persoone, E.P. Jaspers, and C. Claus, eds.) State Uni. Ghent \& Instit. Mar. Sci. Res., Bredene, Belgium. pp. 625-655.

Percell, R., and A.E.V. Haschemeyer. 1980. Effects of temperature on L-leucine transport in toadfish liver in vivo. Biochim. Biophys. Acta 602: 653-660. 
Perdew, G.H. 1988. Association of the $A h$ receptor with the $90-\mathrm{kDa}$ heat shock protein. J. biol. Chem. 263: 13802-13805.

Perdew, G.H., and A. Poland. 1988. Purification of the $A h$ receptor from C57BL/6J mouse liver. J. biol. Chem. 263: 9848-9852.

Pesonen, M., and T. Andersson. 1987. Subcellular localization and properties of cytochrome P-450 and UDP glucuronosyl transferase in the rainbow trout kidney. Biochem. Pharm. 36: 823-829.

Pocrnjic, Z., R.W. Mathews, S. Rappaport, and A.E.V. Haschemeyer. 1983. Quantitative protein synthetic rates in various tissues of a temperate fish in vivo by the method of phenylanaline swamping. Comp. Biochem. Physiol. 74B: 735738.

Poellinger, L., and D. Gullberg. 1985. Characterization of the hydrophobic properties of the receptor for 2,3,7,8-tetrachlorodibenzo-p-dioxin. Mol. Pharm. 27: 271-276.

Pohl, R.J., J.R. Bend, A.M. Guardino, and J.R. Fouts. 1974. Hepatic microsomal mixed-function oxidase activity of several marine species from coastal Maine. Drug Metab. Dispos. 2: 545-555.

Poland, A., and E. Glover. 1973. Chlorinated dibenzo-p-dioxins: potent inducers of delta-aminolevulinic acid synthetase and aryl hydrocarbon hydroxylase. II. A study of the structure-activity relationship. Mol. Pharm. 9: 736-747.

Poland, A., and E. Glover. 1974. Comparison of 2,3,7,8-tetrachlorodibenzo-pdioxin, a potent inducer of aryl hydrocarbon hydroxylase, with 3-methylcholanthrene. Mol. Pharm. 10: 349-359.

Poland, A., E. Glover, and A.S. Kende. 1976. Stereospecific, high affinity binding of 2,3,7,8-tetrachlorodibenzo-p-dioxin by hepatic cytosol: evidence that the binding species is the receptor for the induction of aryl hydrocarbon hydroxylase. J. biol. Chem. 251: 4936-4946.

Poulos, T.L., B.C. Finzel, I.C. Gunsalus, G.C. Wagner, J. Kraut. 1985. The $2.6 \AA$ crystal structure of Pseudomonas putida cytochrome P-450. J. biol. Chem. 260: $16122-16130$.

Pyerin, W., F. Horn, and H. Taniguchi. 1987. Posttranslational modifications of the cytochrome P-450 monooxygenase system. J. Cancer Res. Clin. Oncol. 113: 155-159.

Ravishankar, H., and G. Padmanaban. 1985a. Regulation of cytochrome P-450 gene expression - studies with a cloned probe. J. biol. Chem. 260: 1588-1592.

Ravishankar, H., and G. Padmanaban. 1985b. Turnover of messenger RNA, apoprotein and haem of cytochrome $\mathrm{P}-450 \mathrm{~b}+\mathrm{e}$ induced by phenobarbitone in rat liver. Biochem. J. 229: 73-79. 
Ryan, D., L. Ramanathan, S. Iida, P. Thomas, M. Haniu, J. Shively, C. Lieber, and W. Levin. 1985. Characterization of a major form of rat hepatic microsomal cytochrome P-450 induced by isoniazid. J. biol. Chem. 260: 6385-6393.

Ryan, D.E., P.E. Thomas, and W. Levin. 1982. Purification and characterization of a minor form of hepatic cytochrome P-450 from rats treated with polychlorinated biphenyls. Arch. Biochem. Biophys. 216: 272-288.

Ryan, D.E., P.E. Thomas, D. Korzeniowski, and W. Levin. 1979. Separation and characterization of highly purified forms of liver cytochrome P-450 from rats treated with polychlorinated biphenyls, phenobarbital and 3-methylcholanthrene. J. biol. Chem. 254: 1365-1374.

Ryan, D.E., S. Iida, A.W. Wood, P.E. Thomas, C.S. Lieber, and W. Levin. 1984. Characterization of 3 highly purified cytochromes P-450 from hepatic microsomes of adult male rats. J. biol. Chem. 259: 1239-1250.

Sadano, H. and T. Omura. 1982. Turnover of different forms of microsomal cytochrome P-450 in rat liver. in Cytochrome P-450, Biochemistry, Biophysics, and Environmental Implications. (E. Hietanen, M. Laitinen, and O. Hänninen, eds.) Elsevier Biomedical Press, NY. pp. 299-306.

Sadano, H., and T. Omura. 1983. Reversible transfer of heme between different molecular species of microsome-bound cytochrome P-450 in rat liver. Biochem. Biophys. Res. Comm. 116: 1013-1019.

Sadler, M.C., and K.W. Renton. 1985. Turnover of hepatic hemoproteins in rainbow trout. Marine Environ. Res. 17: 91-93.

Sanger, F., S. Nicklen, and A.R. Coulson. 1977. DNA sequencing with chainterminating inhibitors. PNAS (USA) 74: 5463-67.

Sanglard, D., O. Käppeli, and A. Fiechter. 1986. The distinction of different types of cytochromes P-450 from the yeasts Candida tropcalis and Saccharomyces uvarum. Arch. Biochem. Biophys. 251: 276-286.

Schenkman, J., I. Jansson, and K. Robie-Suh. 1976. Minireview: the many roles of cytochrome $b_{5}$ in hepatic microsomes. Life Sci. 19: 611-624.

Schenkman, J.B., L.V. Favreau, J. Mole, D.L. Kreutzer, and I. Jansson. 1987. Fingerprinting rat liver microsomal cytochromes P-450 as a means of delineating sexually distinctive forms. Arch. Toxicol. 60: 43-51.

Schwen, R.J., and G.J. Mannering. 1982. Hepatic cytochrome P-450-dependent monooxygenase system of the trout, frog and snake. III. Induction. Comp. Biochem. Physiol. 71B: 445-453.

Silver, G., and K.S. Krauter. 1988. Expression of cytochromes P-450c and P-450d mRNAs in cultured rat hepatocytes. 3-methylcholanthrene is regulated primarily at the post-transcriptional level. J. biol. Chem. 263: 11802-11807. 
Smith, P.K., R.I. Krohn, G.T. Hermanson, A.K. Mallia, F.H. Gartner, M.D. Provenzano, E.K. Fujimoto, N.M. Goeke, B.J. Olson, and D.C. Klenk. 1985. Measurement of protein using bicinchoninic acid. Anal. Biochem. 150: 76-85.

Smolarek, T.A., S.L. Morgan, C.G. Moynihan, H. Lee, R.G. Harvey, and W.M. Baird. 1987. Metabolism and DNA adduct formation of benzo[a]pyrene and 7,12-dimethylbenz[a] anthracene in fish cell lines in culture. Carcinogenesis 8: 1501-1509.

Spies, R.B., and D.W. Rice, Jr. 1988a. Effects of organic contaminants on reproduction of the starry flounder Platichthys stellatus in San Francisco Bay. II. Reproductive success of fish captured in San Francisco Bay and spawned in the laboratory. Mar. Biol.. 98: 191-200.

Spies, R.B., D.W. Rice, Jr., and J. Felton. 1988b. Effects of organic contaminants on reproduction of the starry flounder Platichthys stellatus in San Francisco Bay. I. Hepatic contamination and mixed-function oxidase (MFO) activity during the reproductive season. Mar. Biol.. 98: 181-189.

Spies, R.B., J.S. Felton, and L. Dillard. 1982. Hepatic mixed-function oxidases in California flatfishes are increased in contaminated environments and by oil and PCB ingestion. Mar. Biol.. 70: 117-127.

Statham, C.N., C.R. Elcombe, S.P. Szyjka, and J.J. Lech. 1978. Effect of polycyclic aromatic hydrocarbons on hepatic microsomal enzymes and disposition of methyl-napthalene in rainbow trout in vivo. Xenobiotica 8: 65-71.

Stegeman, J.J. 1979. Temperature influence on basal activity and in detection of mixed function oxtgenase activity in Fundulus heteroclitus. J. Fish. Res. Board Can. 36: 1400-05.

Stegeman, J.J. 1981. Polynuclear aromatic hydrocarbons and their metabolism in the marine environment. in: Polycyclic Hydrocarbons and Cancer, Vol. 3. (H.V. Gelboin and P.O. Ts'o, eds.) Academic Press, NY. pp. 1-60.

Stegeman, J.J. 1985. Benzo[a]pyrene oxidation and microsomal enzyme activity in the mussel (Mytilus edulis) and other bivalve mollusc species from the western N. Atlantic. Mar. Biol. 89: 21-30.

Stegeman, J.J., A.M. Pajor, and P. Thomas. 1982. Influence of estradiol and testosterone on cytochrome P-450 and monooxygenase activity in immature brook trout, Salvelinus fontanalis. Biochem. Pharm. 31: 3979-3989.

Stegeman, J.J., A.V. Klotz, B.R. Woodin, and A.M. Pajor. 1981. Induction of hepatic cytochrome P-450 in fish and the indication of environmental induction in scup (Stenotomus chrysops). Aquatic Tox. 1: 197-212.

Stegeman, J.J., and B.R. Woodin. 1984. Differential regulation of hepatic xenobiotic and steroid metabolism in marine teleost species. Marine Environ. Res. 14: $422-425$. 
Stegeman, J.J., and M. Chevion. 1980. Sex differences in cytochrome P-450 and mixed function oxidase activity in gonadally mature trout. Biochem. Pharm. 28: $1686-1688$.

Stegeman, J.J., and M.O. James. 1985. Individual variations in patterns of benzo[a]pyrene metabolism in the marine fish scup (Stenotomus chrysops). Marine Environ. Res. 17: 122-124.

Stegeman, J.J., and P.J. Kloepper-Sams. 1987. Cytochrome P-450 isozymes and monooxygenase activity in aquatic animals. Environ. Health Perspect. 71: 8795.

Stegeman, J.J., and R.L. Binder. 1979. High benzo[a]pyrene hydroxylase activity in the marine fish Stenotomus versicolor. Biochem. Pharm. 28: 16861688.

Stegeman, J.J., B.R. Woodin, A.V. Klotz, R.E. Wolke, and N.R. OrmeJohnson. 1982. Cytochrome P-450 and monooxygenase activity in cardiac microsomes from the fish Stenotomus chrysops. Mol. Pharm. 21: 517-526.

Stegeman, J.J., B.R. Woodin, and A. Goks $\varnothing y r .1988$. Apparent cytochrome P-450 induction as an indication of exposure to environmental chemicals in the flounder Platichthys flesus. Mar. Ecol. Prog. Ser. 46: 55-60.

Stegeman, J.J., B.R. Woodin, S.S. Park, P.J. Kloepper-Sams, and H.V. Gelboin. 1985. Microsomal cytochrome P-450 function in fish evaluated with polyclonal and monoclonal antibodies to cytochrome P-450E from scup (Stenotomus chrysops). Marine Environ. Res. 17: 83-86.

Stegeman, J.J., F.Y. Teng, and E.A. Snowberger. 1987. Induced cytochrome P-450 in winter flounder (Pseudopleuronectes americanus) from coastal Massachusetts evaluated by catalytic assay and monoclonal antibody probes. Can. J. Fish. Aquat. Sci. 44: 1270-1277.

Stegeman, J.J., M.J. Melancon, and B.R. Woodin. 1984. In vitro and in vivo metabolism of alpha-naphthoflavone (ANF) and B-naphthoflavone (BNF) in fish. Pharmacologist 26: 172 .

Stegeman, J.J., P.J. Kloepper-Sams, and J.W. Farrington. 1986. Monooxygenase induction and chlorobiphenyls in the deep sea fish Coryphaenoides armatus. Sci. 231: 1287-1289.

Taylor, B.A. 1971. Strain distribution and linkage tests of 7,12-dimethylbenzanthracene (DMBA) inflammatory response in mice. Life Sci. 10: 11271134.

Tijssen, P. 1985. The nature and structure of antibodies. Chapter 6, Practice and theory of enzyme immunoassays. Vol. 15, Laboratory Techniques in Biochemistry and Molecular Biology, (R.H. Burdon and P.H. van Knippenenberg, eds.), Elsevier, NY. pp. 79-93. 
Tukey, R.H., R.R. Hannah, M. Negishi, D.W. Nebert, and H.J. Eisen. 1982. The $A h$ locus: correlation of intranuclear appearance of inducer-receptor complex with induction of cytochrome $\mathrm{P}_{1} 450$ mRNA. Cell 31: 275-284.

van Waarde, A. 1983. Aerobic and anaerobic ammonia production in fish. Comp. Biochem. Physiol. 74B: 675-684.

Verdina, A., G. deAngelis, E. Funari, E. Testai, and L. Vittozzi. 1987. Xenobiotic-metabolizing enzyme systems in test fish II. The ethylmorphine $\mathrm{N}$-demethylase activity of guppy (poecilia reticulata) liver. Comp. Biochem. Physiol. 88B: 619-624.

Vodicnik, M.J., L.A. Rau, and J.J. Lech. 1984. The effect of monooxygenase inducing agents on the incorporation of $\left[{ }^{35} \mathrm{~S}\right]$-methionine into hepatic microsomal protein of rainbow trout (Salmo gairdneri). Comp. Biochem. Physiol. 79C: 271276.

Voorman, R., and S.D. Aust. 1988. Inducers of cytochrome P-450d: influence on microsomal catalytic activities and differential regulation by enzyme stabilization. Arch. Biochem. Biophys. 262: 76-84.

Watson, A.J., and O. Hankinson. 1988. DNA transfection of a gene repressing aryl hydrocarbon hydroxylase induction. Carcinogenesis 9: 1581-1586.

Waxman, D.J. 1988. Interactions of hepatic cytochromes P-450 with steroid hormones. Regioselectivity and stereospecificity of steroid metabolism and hormonal regulation of rat P-450 enzyme expression. Biochem. Pharm. 37: 7184.

Waxman, D.J., D.P. Lapenson, S.S. Park, C. Attisano, and H.V. Gelboin. 1987. Monoclonal antibodies inhibitory to rat hepatic cytochromes P-450: P-450 form specificities and use as probes for cytochrome P-450-dependent steroid hydroxylations. Mol. Pharm. 32: 615-624.

Weinstein, I.B., A.M. Jeffrey, S. Leffler, P. Pulkrabek, H. Yamasaki, and D. Grunberger. 1987. Interactions between polycyclic aromatic hydrocarbons and cellular macromolecules. in Polycyclic Hydrocarbons and Cancer, Vol. 2. (H.V. Gelboin and P.O. Ts'o, eds.) Academic Press, NY. pp. 4-36.

White, R.E., and M.J. Coon. 1980. Oxygen activation by cytochrome P-450. Ann. Rev. Biochem. 49: 315-369.

Whitlock, J.P., Jr. 1986. The regulation of cytochrome P-450 gene expression. Ann. Rev. Pharmacol. Toxicol. 26: 333-369.

Whitlock, J.P., Jr. 1987. The regulation of gene expression by $2,3,7,8$ tetrachlorodibenzo-p-dioxin. Pharm. Rev. 39: 147-161.

Williams, D.E., and D.R. Buhler. 1982. Purification of cytochromes P-448 from B-naphthoflavone-treated rainbow trout. Biochim. Biophys. Acta 717: 398-404. 
Williams, D.E., and D.R. Buhler. 1983. Purified forms of cytochrome P-450 from rainbow trout with high activity toward conversion of aflatoxin $\mathrm{Bl}$ to aflatoxin B1-2,3 epoxide. Cancer Res. 43: 4752-4756.

Williams, D.E., and D.R. Buhler. 1984. Benzo[a]pyrene hydroxylase catalyzed by purified isozymes of cytochrome P-450 from B-naphthoflavone-fed rainbow trout. Biochem. Pharm. 33: 3743-3753.

Williams, D.E., R.T. Okita, D.R. Buhler, and B.S. Masters. 1984. Regiospecific hydroxylation of lauric acid at the (omega-1) position by hepatic and kidney microsomal cytochromes P-450 from rainbow trout. Arch. Biochem. Biophys. 231: 503-510.

Yeowell, H.N., D.J. Waxman, G.A. LeBlanc, P. Linko, and J.A. Goldstein. 1988. Induction of rat cytochrome P-450 3 and its mRNA by $3,4,5,3^{\prime}, 4^{\prime}, 5^{\prime}-$ hexachlorobiphenyl. Mol. Pharm. 33: 272-278.

Zak, R., A.F. Martin, and R. Blough. 1979. Assessment of protein turnover by use of radioisotopic tracers. Physiol. Rev. 59: 407-447.

Zar, J.H. 1974. Biostatistical Analysis. Prentice-Hall, Inc., Englewood, NJ. 620 pp. 